



\title{
TEMAS SELECTOS
}

3

\author{
HACIA EL ÁMBITO
}

\section{DEL DERECHO ADMINISTRATIVO}

\author{
Ricardo Tapia Vega \\ Pedro José Carrasco Parrilla
}

Eduardo Oliva Gómez

(coordinadores)
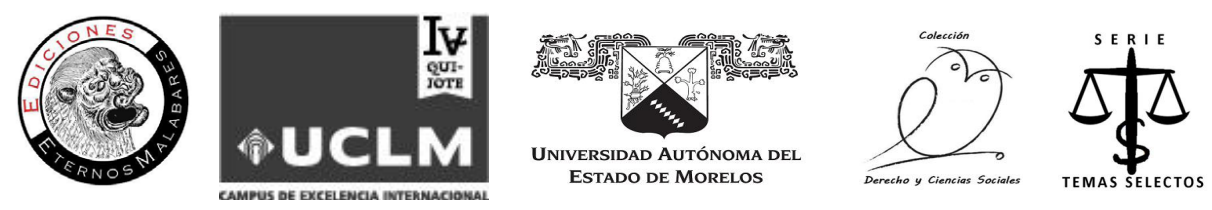
Hacia el ámbito del derecho administrativo / Dr. Ricardo Tapia Vega, Coord. ; Dr. Pedro José Carrasco Parrilla, Coord. ; Dr. Eduardo Oliva Gómez, Coord. --

México, 2016.

200 p. ; 21.5 cm. -- (Colección Derecho y Ciencias Sociales. Temas Selectos)

Contiene índice. -- Textos en inglés y español

ISBN: 978-607-9287-26-9

KKT5162H335

1. Tapia Vega, Ricardo, coordinador

II. Carrasco Parrilla, Pedro José, coordinador

III. Oliva Gómez, Eduardo, coordinador

TEMAS SELECTOS 3. HACIA EL ÁMBITO DEL DERECHO ADMINISTRATIVO

Ricardo Tapia Vega

Pedro José Carrasco Parrilla

Eduardo Oliva Gómez

D.R. (C) Ricardo Tapia Vega, Pedro José Carrasco Parrilla, Eduardo Oliva Gómez 2016

D.R. (C) Ediciones Eternos Malabares, 2016

Ediciones Eternos Malabares, S. C.

Fovissste Cantarranas E 7 Dpto. 101

Acapantzingo, C.P. 62440

Cuernavaca, Morelos, México

eternosmalabares@yahoo.com.mx

Universidad Autónoma del Estado de Morelos

Av. Universidad 1001

Col. Chamilpa, C.P. 62209

Cuernavaca. Morelos

publicaciones@uaem.mx

ISBN 978-607-9287-26-9

IMPRESO EN MÉXICO 
COLECCIÓN:

Derecho y Ciencias Sociales

DIRECTOR:

Dr. Ricardo Tapia Vega

SERIE:

Temas Selectos

DIRECTORES:

Dr. Ricardo Tapia Vega

Dr. Eduardo Oliva Gómez

CONSEJO EDITORIAL:

Raúl Vergara Mireles (Director de la Facultad de Derecho y Ciencias Sociales de la Universidad Autónoma del Estado de Morelos)

Enrique Pérez Salazar (Universidad Autónoma del Estado de Morelos, becario de doctorado, CONACYT, PNPC 002764, de la Facultad de Derecho y Ciencias Sociales)

Miriela Sosa González (Universidad de La Habana, Cuba, becaria de doctorado, CONACYT, PNPC 002764, de la Facultad de Derecho y Ciencias Sociales de la Universidad Autónoma del Estado de Morelos)

Tatiana Vanessa González Rivera (Universidad Centroamericana, Manuagua, Nicaragua, becaria de doctorado, CONACYT, PNPC 002764, de la Facultad de Derecho y Ciencias Sociales de la Universidad Autónoma del Estado de Morelos)

Erika Nayeli Hernández Castelo (Universidad Autónoma del Estado de Morelos, becaria de maestría, CONACYT, PNPC 002478, de la Facultad de Derecho y Ciencias Sociales)

Juan Luis García Arellano (Universidad Autónoma del Estado de Morelos, becario de maestría, CONACYT, PNPC 002478, de la Facultad de Derecho y Ciencias Sociales)

Kessia Damaris Alue Ramírez (Universidad Autónoma del Estado de Morelos, becaria de maestría, CONACYT, PNPC 002478, Facultad de Derecho y Ciencias Sociales)

Lizeth Juliana García Atra (Universidad Colegio Mayor de Cundinamarca, Colombia, becaria de maestría, CONACYT, PNPC 002478, de la Facultad de Derecho y Ciencias Sociales de la Universidad Autónoma del Estado de Morelos)

Madelaine Lizbeth Vargas Ocampo (Universidad Autónoma del Estado de Morelos, becaria de maestría, CONACYT, PNPC 002478, de la Facultad de Derecho y Ciencias Sociales)

ARBITRAJE DE LA OBRA:

Doctor Gabriel Andrés Cano Marín

COORDINADORES: Doctores en Derecho Ricardo Tapia Vega, Pedro José Carrasco Parrilla y Eduardo Oliva Gómez

\section{CORRECCIÓN DE ESTILO: Ediciones Eternos Malabares}

\section{ILUSTRACIÓN DE PORTADA: Ernesto Alonso}

\section{ISBN: 978-607-9287-26-9}

Todos los derechos reservados. Esta publicación no puede ser reproducida, ni en todo ni en parte, ni registrada en o transmitida por un sistema de recuperación de información, en ninguna forma ni por ningún medio, sea mecánico, fotoquímico, electrónico, magnético, electroóptico, por fotocopia, o cualquier otro, sin el permiso previo, por escrito, de la editorial y el autor. 


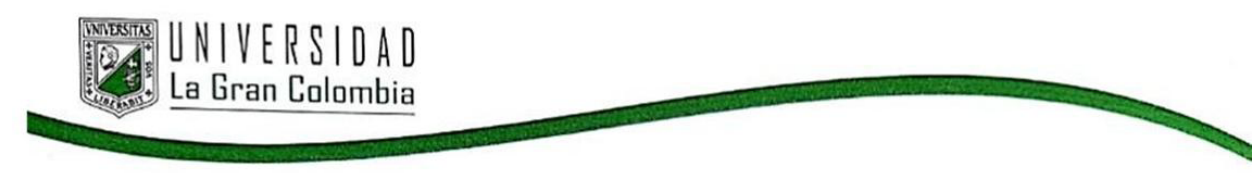

Bogotá D.C., 18 de noviembre de 2015

Señores

Universidad Autónoma del Estado de Morelos

Asunto: Dictamen razonado

Comedidamente me permito emitir el concepto sobre el libro Temas Selectos: Hacia el Ámbito del Derecho Administrativo, coordinado por Ricardo Tapia Vega, Pedro José Carrasco Parrilla y Eduardo Oliva Gómez, el dictamen:

1. El libro aporta a la comprensión de las nuevas tendencias en el estudio del Derecho Administrativo de manera clara y precisa.

2.- La estructuración y selección de los capítulos cuenta con una secuencia lógica que da conexión a toda la obra.

3. Los análisis hechos en el libro, sobre los diferentes temas de actualidad, son originales y sirven para la comprensión de la evolución del Derecho Administrativo durante la última década.

4. El trabajo cumple con los parámetros técnicos de un trabajo de calidad.

5. La redacción es clara y las ideas son expresadas de manera sencilla.

Por lo anteriormente expuesto, considero que el libro cuenta con los suficientes requisitos para su publicación como libro de texto y a su vez, cumple con los parámetros para ser considerado de calidad.

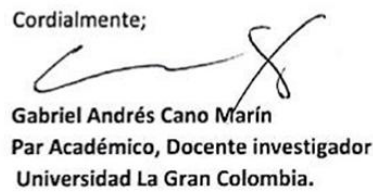

Universidad La Gran Colombia.

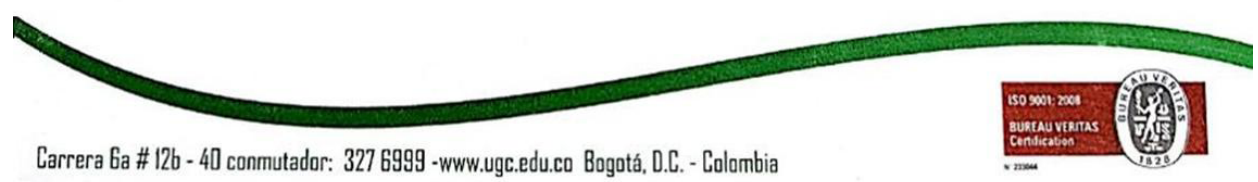




\section{ÍNDICE}

Prólogo

Dr. José Antonio Moreno Molina

La autoridad administrativa y su obligación de tutela de los derechos humanos en México

Ricardo Tapia Vega

El derecho fundamental a una buena administración pública en México

Juan Manuel Ortega Maldonado

La jurisdicción contencioso-administrativa y el acceso a la justicia

Jorge Alberto Estrada Cuevas 51

Los retos de la argumentación en los convenios para evitar la doble imposición en la globalización

Juan de Dios González Ibarra

Barbara Edith Orihuela Rosas 63

Respecto al levantamiento de una nueva acta de nacimiento para el reconocimiento de la identidad de género: ¿Resolución administrativa o resolución judicial?

Eduardo Oliva Gómez

Los administrados como titulares de derechos y garantías en sus relaciones con la administración tributaria en España

Pedro José Carrasco Parrilla 97

El alcance de la actio in rem verso en las normas de contratos del sector público. Especial referencia al enriquecimiento injusto o sin causa de la administración en materia de contratos

Jesús Punzón Moraleda......

La adjudicación de los contratos no sara por los poderes adjudicadores que no tienen la consideración de administración pública

Francisco Puerta Seguido 145

Las competencias de los entes locales en materia de turismo tras la reforma del régimen local español

Antonio Villanueva Cuevas

La factura electrónica en la contratación pública

Alfredo Ramos 



\section{Prólogo}

Con gran satisfacción y asumiéndolo como un verdadero honor presento esta obra colectiva, fruto de la colaboración entre la División de Estudios Superiores de Posgrado de la Universidad Autónoma del Estado de Morelos y la Universidad de Castilla-La Mancha, en la que se reflexiona con gran acierto sobre conceptos, instituciones y reglas de Derecho público de la legislación mexicana, española y comparada.

Considero un gran acierto la publicación de este libro que no viene sino a reflejar la integración entre México y España, dos países con tanta historia común, que han compartido tradiciones, cultura y Derecho.

Los destacados trabajos que se recogen en la publicación, elaborados por los profesores Jorge Alberto Estrada Cuevas, Juan de Dios González Ibarra, Bárbara Edith Orihuela Rosas, Juan Manuel Ortega Maldonado, Eduardo Oliva Gómez, Ricardo Tapia Vega, Pedro José Carrasco Parrilla, Francisco Eusebio Puerta Seguido, Jesús Punzón Moraleda, Alfredo Ramos Pérez-Olivares y Antonio Villanueva Cuevas, todos ellos grandes especialistas en Derecho público, abordan cuestiones de la máxima importancia en el Derecho administrativo contemporáneo.

En efecto, entre los grandes retos actuales para los iusadministrativistas se encuentra el análisis de la contratación pública, los derechos y garantías de los ciudadanos en sus relaciones con la Administración tributaria, las competencias de los entes locales, la jurisdicción contencioso-administrativa, la consagración del Derecho fundamental a una buena administración pública y la tutela de los derechos humanos, cuestiones todas ellas abordadas en profundidad en la presente obra a través de magníficos trabajos, de gran calidad y profundidad jurídica.

La realidad administrativa actual se encuentra fragmentada y el Derecho administrativo es en nuestros días una rama de la ciencia jurídica en revisión. Son pocos los sectores del Derecho administrativo que no están sometidos a una renovación sustancial, de raíz, de las propias estructuras en las que se asienta, que parecen cambiar casi de la noche a la mañana. Raro es el día que no se nos presenta junto con una novedad más del ordenamiento administrativo. Algunas de ellas son meramente puntuales, otras son medulares. Sin embargo, todas ellas llevan a una conclusión: la dificultad de definir lo que es hoy el Derecho administrativo.

Santamaria Pastor ha reflejado esta complejidad del Derecho administrativo en sus Fundamentos de Derecho administrativo':

"La calificación del Derecho en general, y de cada una de sus ramas particulares, como una ciencia, fue una reivindicación constante de los juristas desde fines del siglo XVIII, afanosos de lograr una equiparación de dignidad con las

${ }^{1}$ Ed. Centro de Estudios Ramón Areces, Madrid, 1988, p. 61. 
ciencias experimentales: una tarea esta problemática, en la medida en que el conocimiento científico requiere un cierto grado de estabilidad en el objeto a analizar, en tanto que el Derecho opera sobre una realidad cambiante, la realidad social.

Esta realidad adquiere caracteres dramáticos en el Derecho administrativo, cuyo objeto posee un nivel máximo de inestabilidad y variabilidad. La Administración es un aparato dependiente de la configuración del Estado en cada lugar y en cada momento histórico y de la forma de sus relaciones con la sociedad civil; y sometido, por tanto, a cambios incesantes en su estructura y en sus procedimientos y técnicas de actuación, paralelos a los que la comunidad política experimenta. De ahí que frente a la acusada homogeneidad sistemática de los tratados de Derecho civil de la Europa continental -fieles, en lo básico, al esquema de Savigny-, la comparación de obras de Derecho administrativo muy próximas en el tiempo y en el espacio arroja diferencias acusadas; radicales a veces y siempre desconcentantes.

(...) El inconveniente mayor se encuentra en el propio desfase que inevitablemente se produce entre el Derecho administrativo y la realidad social sobre la que ha de actuar: la lentitud con que tiende a evolucionar el conocimiento científico y la propia inercia de las construcciones recibidas hace que el Derecho administrativo existente en cada momento sea el adecuado a una situación histórica siempre superada. De esta forma, a la frustante sensación de fugacidad del propio trabajo científico se une la ansiedad producida por la conciencia de un gap tecnológico permanente".

En un sentido similar se ha pronunciado también Muñoz Machado:

"Frente a la estabilidad de otras disciplinas, un dato muy acusado del Derecho Administrativo es su extraordinario apego a la realidad social; esta vinculación impone la acomodación a las nuevas necesidades y se traduce en un proceso evolutivo y constante; el Derecho Administrativo es un producto de formación histórica que ni ha llegado ni quizá llegue nunca a consolidarse en una formulación definitiva, ya que la realidad social, a la que está íntimamente unido, aporta continuamente innovaciones que provocan mutaciones, no sólo en los procedimientos sino también en lo más característico de su sustancia" ${ }^{2}$.

No cabe duda de que una de las características más destacadas del Derecho administrativo actual es la mutabilidad o variabilidad del mismo, que tiene una manifestación pragmática incontestable en la propia contingencia del sistema normativo escrito del Derecho Administrativo, sobre lo que han llamado la atención los profesores García de Enterría Y T.R. Fernández ${ }^{3}$.

Como muestra paradigmática de esta característica típica del Derecho administrativo, basta observar la recentísima evolución normativa en el campo de los contratos públicos, que es objeto de análisis en varios de los trabajos que recoge este libro.

\footnotetext{
${ }^{2}$ Muñoz Machado, Las concepciones del Derecho Administrativo y la idea de participación en la Administración, RAP nº 84, 1977, pág. 521.

${ }^{3}$ Curso de Derecho Adminitrativo, I, Civitas, $5^{a}$ ed., Madrid, 1989, pág. 73.
} 
La constante aprobación tanto en España como en México y en toda América latina de nuevas normas básicas reguladoras de la contratación pública ${ }^{4}$, ha impedido a este decisivo sector del ordenamiento jurídico ${ }^{5}$ de una estabilidad y seguridad jurídica que necesita de forma imperiosa ${ }^{6}$.

La desmedida proliferación normativa en el $\operatorname{sector}^{7}$ ha ocasionado unas notables dificultades a todos los operadores jurídicos y económicos de los contratos públicos.

Otro rasgo primario del Derecho administrativo que permite concluir sus particularidades es su carácter público. En el presente libro se aprecia la hoy decisiva dualidad Derecho público-Derecho privado ${ }^{8}$, así como la estrecha interconexión del Derecho administrativo con otras ramas del Ordenamiento jurídico, significativamente con el Derecho constitucional y con el Derecho tributario, reguladores, asimismo, de la actividad del Estado9.

Desde este prólogo quiero trasladar mi sincera felicitación a todos los autores de los trabajos presentados en el libro, así como a los directores del mismo que han impulsado esta importante obra conjunta que sin duda abre el camino a nuevas publicaciones mexicano-españolas en el campo del Derecho público.

En Cuenca (España), a 23 de octubre de 2015.

José Antonio Moreno Molina Catedrático de Derecho Administrativo de la Universidad de Castilla-La Mancha

\footnotetext{
${ }^{4}$ Véase Carlón Ruíz, M., "La Ley de Contratos de las Administraciones Públicas y su carácter estructurante del ordenamiento jurídico", en AAVV, Comentarios a la Ley de Contratos de las Administraciones Públicas (dirección Gomez-Ferrer Morant), Civitas, Madrid, 2004.

${ }^{5}$ La contratación pública ha adquirido en los Estados del siglo XXI una gran importancia política, social y económica. Según datos de la Comisión Europea, los contratos de las Administraciones públicas suponen más del 19\% del Producto Interior Bruto de la Unión Europea.

Véase el documento "Public Procurement Indicators 2009", Comisión Europea (DG Mercado Interior), 11 de noviembre de 2010, http://ec.europa.eu/internal market/publicprocurement/docs/ indicators2009_en.pdf (fecha de consulta 23 de octubre de 2015).

${ }^{6}$ Véase Gimeno Feliú, J.M., "Novedades de la Ley de Contratos del Sector Público de 30 de octubre de 2007 en la regulación de los procedimientos de adjudicación de los contratos públicos", Civitas, Pamplona, 2010 y La Ley de Contratos del Sector Público: ¿una herramienta eficaz para garantizar la integridad? Mecanismos de control de la corrupción en la contratación pública, REDA 147 (2010), págs. 518 y ss.

${ }^{7}$ Pocos ámbitos como el de la contratación pública ejemplifican la legislación "motorizada" (Garcia de Enterria, E.: Justicia y seguridad jurídica en un mundo de leyes desbocadas, Civitas, Madrid, 1999, p. 48) característica de los ordenamientos jurídicos contemporáneos y especialmente de España en los últimos decenios.

${ }^{8}$ Vid. los tradicionales criterios de distinción en Pugliatti, S., "Diritto pubblico e diritto privato", Enciclopedia del Diritto, Giuffrè, Varese, 1964, pags. 696 y ss.; Garcia Pelayo: Voz "Derecho público", en VV.AA. Nueva enciclopedia jurídica. Seix. Barcelona, 1950. Vol I, Págs: 979 ss; Zanobini: Corso di diritto amministrativo. $8^{\mathrm{a}}$ ed. Giuffrê. Milano, 1958. Págs: 23 ss. y Bullinger: Derecho público y Derecho privado. INAP. Madrid, 1976.

${ }^{9}$ Vedel, Les bases constitutionnelles du droit administratif. EDCE, 1954, págs. 21 y ss.
} 

MÉXICO 



\section{La autoridad administrativa y su obligación de tutela de los derechos humanos en México Ricardo Tapia Vega*}

Resumen: Este ensayo ofrece algunos conceptos descriptivos sobre la autoridad administrativa, los derechos humanos y sus garantías, y la citada autoridad frente a la tutela de los derechos humanos en los sistemas mexicano e interamericano; y concluye con algunas reflexiones en las que bosqueja tópicos, hacia aquél sistema, como la tutela de derechos humanos por particulares equiparables a autoridad administrativa, la obligatoriedad de la jurisprudencia para la autoridad referida, la interpretación e integración de la norma en sede administrativa, y la promoción de los derechos humanos como mecanismo para su tutela.

Palabras clave: autoridad administrativa, particulares, equiparable, derechos humanos, tutela, estado de derecho, estado constitucional de derecho, sistema mexicano, jurisprudencia, interpretación, integración, promoción.

\footnotetext{
* Doctor en Derecho y Globalización, con mención honorífica, por la Facultad de Derecho y Ciencias Sociales de la Universidad Autónoma del Estado de Morelos (CONACYT-PNPC 002764). Catedrático en licenciatura y posgrado en dicha facultad y en diversas universidades privadas. Especialista en "Justicia constitucional, interpretación y aplicación de la Constitución”, por la Universidad de Castilla-La Mancha, España. Autor en diversos artículos, revistas y libros. Abogado litigante. Correo electrónico: tapiay_asociados@icloud.com
} 
Abstract: This essay provides some descriptive concepts about the administrative authority, human rights and their guarantees, and administrative authority over the protection of human rights in the Mexican and the Interamerican systems; concluding with some reflections on topics sketching over the system protection of human rights by individuals comparable to administrative authority, and by the latter in matching individuals; the compulsory jurisprudence administrative; the interpretation and integration of the rule in administrative headquarters; and the promotion of human rights as mechanism for protection.

Key words: administrative authorities, individuals, comparable, human rights, guardianship, rule of law, constitutional rule of law, Mexican system, jurisprudence, interpretation, integration, promotion.

\section{La autoridad administrativa}

En el sistema jurídico mexicano se entiende por autoridad a quien "dicta, ordena, ejecuta o trata de ejecutar el acto que crea, modifica o extingue situaciones jurídicas en forma unilateral y obligatoria; $u$ omita el acto que de realizarse crearía, modificaría o extinguiría dichas situaciones jurídicas". ${ }^{1}$

Ahora, el concepto de "autoridad" no sólo se contextualiza respecto de las relaciones verticales de supra a subordinación ${ }^{2}$ entre un ente del poder público y un particular, sino también en relaciones horizontales de coordinación ${ }^{3}$ cuando uno de los particulares intervinientes realiza materialmente "actos equivalentes a los de autoridad, que afecten

\footnotetext{
${ }^{1}$ Véase el artículo 5, fracción II, primer párrafo, de la Ley de Amparo.

${ }^{2}$ Estas relaciones son las que se entablan entre gobernantes y gobernados, por actuar los primeros en un plano superior a los segundos, en beneficio del orden público y del interés social, relaciones que se regulan por el derecho público. Véase la tesis aislada I.15o.A.36 K, registro 168507, emitida en la $9^{a}$ época por el Décimo Quinto Tribunal Colegiado en materia Administrativa del Primer Circuito, bajo la ponencia del magistrado Armando Cortés Galván, de rubro: “AMPARO. EN EL JUICIO RELATIVO NO ES PROCEDENTE RECLAMAR ACTOS DERIVADOS DE RELACIONES DE SUPRAORDINACIÓN O DE COORDINACIÓN, SÓLO DE SUPRA A SUBORDINACIÓN ENTRE AUTORIDADES Y PARTICULARES".

${ }^{3}$ Estas relaciones son las que se dan entre los particulares, en las cuales éstos actúan en un mismo plano, es decir, en igualdad y bilateralidad (incluyendo al Estado cuando actúa como particular, es decir, sin imperio). Véase la tesis aislada I.15o.A.36 K, referida en la nota al pie inmediata anterior.
} 
derechos ${ }^{4} . . \mathrm{y}$ cuyas funciones estén determinadas por una norma general" . 5

Respecto del acto administrativo, el mismo ha sido definido como "toda manifestación de voluntad, deseo, conocimiento o juicio que realiza la administración pública en ejercicio de la potestad administrativa" 6 .

Asimismo, debe tenerse en cuenta que la administración realiza actos contractuales y unilaterales, siendo los actos contractuales los que nacen del acuerdo entre la entidad administrativa y los particulares (v.gr.: la celebración de contratos); y los actos unilaterales, los realizados exclusivamente por la voluntad del ente administrativo (v.gr.: la imposición de una multa). Estos actos unilaterales se clasifican a su vez en individuales y generales: los primeros tienen efectos jurídicos respecto de una o varias personas determinadas, acerca de uno o varios casos específicos (v.gr.: el otorgamiento de una licencia de construcción, que confiere autorizaciones específicas a sus titulares); los segundos, producen efectos jurídicos respecto de un conglomerado determinado o de una generalidad de personas o casos (v.gr.: los reglamentos). ${ }^{7}$

En este orden de ideas puede connotarse como autoridad administrativa, al servidor público o al particular que realiza actos administrativos en las condiciones señaladas en los dos párrafos iniciales de este apartado.

\section{Los derechos humanos y su tutela}

Los derechos humanos son el conjunto de prerrogativas sustentadas en la dignidad humana, cuya realización efectiva resulta indispensable

\footnotetext{
${ }^{4}$ Creando, modificando o extinguiendo situaciones jurídicas en forma unilateral y obligatoria, $\mathrm{u}$ omitiendo el acto que de realizarse crearía, modificaría o extinguiría dichas situaciones jurídicas.

${ }^{5}$ Véase el artículo 5, fracción II, segundo párrafo, de la Ley de Amparo.

${ }^{6}$ Véase la tesis aislada I.4o.A.413 A, registro 182245, emitida en la $9^{a}$ época por el Cuarto Tribunal Colegiado en Materia Administrativa del Primer Circuito, bajo la ponencia del magistrado Jean Claude Tron Petit, de rubro "ASENTAMIENTOS HUMANOS. EL PROGRAMA DELEGACIONAL DE DESARROLLO URBANO PARA CUAJIMALPA DE MORELOS, VERSIÓN 1997, NO ES UNA REGLA GENERAL, ABSTRACTA E IMPERSONAL SEMEJANTE A UNA LEY, SINO UN ACTO ADMINISTRATIVO CON EFECTOS GENERALES QUE DEBE CUMPLIR CON LA GARANTÍA DE FUNDAMENTACIÓN Y MOTIVACIÓN".

${ }^{7}$ Cfr. s/a, El acto administrativo, p. 125, visible en el sitio de internet: http:/ / biblio.juridicas.unam.mx/libros/4/1920/10.pdf (consultado el 15 de octubre de 2015).
} 
para el desarrollo integral de la persona ${ }^{8}$; adicionalmente, constituyen verdaderos límites a la soberanía o potestad estatal ${ }^{9}$, e incluso, a la autonomía de sus propios titulares ${ }^{10}$. Igualmente debe enunciarse que estos derechos son universales, interdependientes, indivisibles y progresivos ${ }^{11}$, y están a menudo contemplados y garantizados en las constituciones y leyes, así como en los tratados, en el derecho internacional consuetudinario, en los principios generales y en otras fuentes del derecho ${ }^{12}$. Cuando estos derechos se positivizan en textos normativos constitucionales o convencionales internacionales se denominan derechos fundamentales.

Tras la ignominia del holocausto, al finalizar la Segunda Guerra Mundial, surge entre los estados la convicción de que el respeto de los derechos de la persona no es una cuestión exclusiva de cada uno de ellos, sino de interés general de la comunidad internacional ${ }^{13}$, y en ese tenor, comienzan a aparecer diversos instrumentos internacionales de tutela de esos derechos, a la vez que los estados empiezan a reconocerlos en sus ordenamientos constitucionales, iniciando la llamada internacionalización de los derechos humanos ${ }^{14}$.

En esas condiciones, se ha venido abandonando el modelo tradicional paleopositivista de "Estado de Derecho", consistente en la primacía de la ley como producto de la omnipotencia democrática de la mayoría parlamentaria, al considerarse que ni siquiera por unanimidad se puede legítimamente decidir la violación de un derecho humano, pues ésta categoría de derechos está en la esfera de lo indecidible; así, se ha venido transitando hacia un modelo de "Estado Constitucional de

\footnotetext{
${ }^{8}$ Cfr. Sitio de internet: http:/ / www.cndh.org.mx/Que_Son_Derechos_Humanos (consultado el 11 de octubre de 2015).

${ }^{9}$ Cfr. Cilia López, José Francisco, Los derechos humanos y su repercusión en el control de constitucionalidad y de convencionalidad, Ed. Porrúa, ed. $1^{\mathrm{a}}$, México, 2015, pp. 22-23.

${ }^{10}$ Por ejemplo, ni siquiera voluntariamente se puede alienar la propia vida o libertad. Véase Ferrajoli, Luigi, Derechos y Garantías. La ley del más débil, Ed. Trotta, ed. 7ª Madrid, España, 2010, p. 48.

${ }^{11}$ Características reconocidas en el derecho comparado, por ejemplo, en la Constitución Política de los Estados Unidos Mexicanos (en adelante CPEUM), en su artículo 1, párrafo tercero; o por la Constitución Política del Estado Plurinacional de Bolivia, en su artículo 13.I.

${ }^{12}$ Cfr. con el sitio de internet: http://www.ohchr.org/SP/Issues/Pages/WhatareHumanRights.aspx (consultado el 11 de octubre de 2015).

${ }^{13}$ Cfr. Suprema Corte de Justicia de la Nación, La protección no jurisdiccional de los derechos humanos, Ed. Suprema Corte de Justicia de la Nación, ed. 1ª , México, 2008, p.105.

${ }^{14}$ Cfr. Caballero Ochoa, José Luis, citado por la Suprema Corte de Justicia de la Nación en su obra Derechos Humanos. Parte General, t. 1, Ed. Suprema Corte de Justicia de la Nación, ed. 1ª , México, 2013, p.110.
} 
Derecho", donde el derecho no es ya creación exclusiva de consensos de mayoría, sino que principalmente es producto del propio derecho, pues en su elaboración deben respetarse los derechos humanos como límites infranqueables. ${ }^{15}$

Ahora, para la realización de esa categoría de derechos, se requiere en la praxis de ciertas herramientas tendientes a reducir la distancia estructural entre normatividad y efectividad, y por tanto, encaminadas a posibilitar la máxima eficacia de esas prerrogativas en coherencia con su estipulación constitucional. A esas herramientas tutelares se les ha denominado "garantías", pues se constituyen en deberes correlativos a los referidos derechos, que instauran ya obligaciones de prestación o prohibiciones de lesión (garantías primarias), o bien, de sanción, reparación o nulificación respecto de las violaciones a dichos derechos (garantías secundarias) ${ }^{16}$. Así, en el contenido de los derechos humanos residen expectativas de actuación, principalmente por parte de la autoridad, por lo que las personas deben contar con los medios que avalen la realidad de tales aspiraciones, y para ello las garantías de protección son técnicas y medios que permiten lograr la eficacia de los mismos. ${ }^{17}$

En ese tenor, existe una relación de subordinación entre derechos humanos y garantías, pues estas últimas sólo existen en función de los derechos que protegen; de tal suerte que pueden existir derechos sin garantías pero no garantías sin derechos. ${ }^{18}$

Es importante destacar también que los derechos fundamentales gozan de una doble cualidad, ya que por una parte se configuran como derechos públicos subjetivos que constituyen verdaderas inmunidades oponibles (función subjetiva); y por la otra, se traducen en elementos objetivos que informan o permean todo el ordenamiento jurídico, en virtud de que unifican, identifican e integran, en un sistema jurídico determinado, a las restantes normas que cumplen funciones más

${ }^{15}$ Cfr. Ferrajoli, Luigi, ob. cit., pp. 19, 20, 25 y 66.

${ }^{16}$ Cfr. Ibídem, pp. 25, 43 y 59.

${ }_{17}$ Véase la tesis aislada 1a. CCLXXXVI/2014 (10a.), registro 2007057, emitida en la 10 época por la Primera Sala de la Suprema Corte de Justicia de la Nación (en adelante SCJN), bajo la ponencia del ministro Alfredo Gutiérrez Ortiz Mena, de rubro "DERECHOS HUMANOS. NATURALEZA DEL CONCEPTO "GARANTÍAS DE PROTECCIÓN”, INCORPORADO AL ARTÍCULO 1o. DE LA CONSTITUCIÓN FEDERAL, VIGENTE DESDE EL 11 DE JUNIO DE 2011".

${ }^{18}$ Véase la tesis jurisprudencial XXVII.3o. J/14 (10a.), registro 2008815, emitida en la $10^{a}$ época por el Tercer Tribunal Colegiado del Vigésimo Séptimo Circuito, bajo la ponencia de la magistrada Livia Lizbeth Larumbe Radilla, de rubro "DERECHOS HUMANOS Y SUS GARANTÍAS. SU DISTINCIÓN". 
específicas (función objetiva) ${ }^{19}$. En esas condiciones, se considera que la violación de dichos derechos implica siempre un hecho contrario a las normas prohibitivas de orden público, destacándose que ese tipo de transgresiones ha sido tradicionalmente sancionada con la nulidad absoluta, apreciable incluso de forma oficiosa. ${ }^{20}$

\section{La autoridad administrativa frente a la tutela de los derechos humanos en el sistema mexicano}

En el sistema mexicano, el Estado está organizado en una república representativa, democrática, laica y federal ${ }^{21}$, con un sistema normativo híbrido de leyes y precedentes judiciales ${ }^{22}$, donde los precedentes jurisprudenciales ${ }^{23}$ son obligatorios (hard law) sólo para los órganos jurisdiccionales, no así para las autoridades legislativas y administrativas $^{24}$ (salvo en materia electoral, en donde son vinculantes

${ }^{19}$ Véase la tesis aislada 1a. XXI/ 2013 (10a.), registro 2002505, emitida en la 10ª época por la Primera Sala de la SCJN, bajo la ponencia del ministro Arturo Zaldívar Lelo de Larrea, de rubro "DERECHOS FUNDAMENTALES. SU DIMENSIÓN SUBJETIVA Y OBJETIVA". En la jurisprudencia constitucional comparada, resultan interesantes, en relación a este mismo tema, entre otras, la sentencia de 25 de febrero de 1975 pronunciada por el Tribunal Constitucional de la República Federal Alemana; la sentencia 53/1985 pronunciada por el Pleno del Tribunal Constitucional de España; y el fallo contenido en el EXP. $\mathrm{N}^{\circ}$ 3330-2004-AA/TC, relativo al caso Ludesminio Loja Mori, resuelto por el Pleno del Tribunal Constitucional de Perú.

${ }^{20}$ Tapia Vega, Ricardo, El proceso en clave de derechos humanos. Hacia el ámbito del derecho privado, en Tapia Vega, Ricardo, et al (coordinadores), Hacia el ámbito del derecho privado, de la serie Temas Selectos, vol. 2, Ed. Eternos Malabares-UAEM, México, 2015, p. 66. Véanse también en el derecho comparado los artículos 1830 del Código Civil Federal mexicano ("es ilícito el hecho que es contrario a las leyes de orden público o a las buenas costumbres"); 6.3 del Código Civil español ("los actos contrarios a las normas imperativas y a las prohibitivas son nulos de pleno derecho, salvo que en ellas se establezca un efecto distinto para el caso de contravención "); 18 del Código Civil argentino ("los actos prohibidos por las leyes son de ningún valor, si la ley no designa otro efecto para el caso de contravención"); etc.

${ }^{21}$ Véase el artículo 40 de la CPEUM.

${ }^{22}$ Estos últimos, en el plano federal, son pronunciados por los siguientes órganos del Poder Judicial de la Federación: Tribunales Colegiados de Circuito, Plenos de Circuito, Salas de la SCJN y Pleno de la misma, además, Sala Superior del Tribunal Electoral del Poder Judicial de la Federación. Al respecto véanse los artículo 94, párrafo décimo; 99, párrafos séptimo y octavo y 107 fracción II, de la CPEUM. Ver también los artículos 217 de la Ley de Amparo, 43 de la Ley reglamentaria de las fracciones I y II del artículo 105 de la CPEUM, y 233 de la Ley Orgánica del Poder Judicial de la Federación.

${ }^{23}$ Producidos por reiteración, contradicción de tesis o modificación de jurisprudencia.

${ }^{24}$ Amén de los dispositivos indicados en la nota 23 supra, véase la tesis jurisprudencial 2a./J. 38/2002, registro 186921, emitida en la $9^{a}$ época, por la Segunda Sala de la SCJN, bajo la ponencia del ministro Mariano Azuela Güitrón, de rubro: "JURISPRUDENCIA SOBRE INCONSTITUCIONALIDAD DE LEYES. LAS AUTORIDADES ADMINISTRATIVAS NO ESTÁN OBLIGADAS A APLICARLA AL CUMPLIR CON LA GARANTÍA 
para las autoridades administrativas ${ }^{25}$ ), y los demás precedentes, que se denominan tesis aisladas, se presentan como criterios orientadores no vinculantes (soft law). En dicho sistema, los tratados internacionales se incorporan mediante el sistema monista al orden nacional una vez ratificada su celebración por el senado de la república ${ }^{26}$.

A partir de las reformas constitucionales de 6 y 10 de junio de 2011, se consolidó en México un cambio fundamental hacia la tutela de los derechos humanos ${ }^{27}$, que modificó los principios filosóficos y políticos que guían las relaciones entre el Estado y los gobernados ${ }^{28}$, siendo quizá la reforma al artículo $1^{\circ}$ constitucional (ocurrida en la segunda de las mencionadas fechas) la más emblemática del nuevo modelo. Dicho numeral, ahora ${ }^{29}$, a la letra dice:

En los Estados Unidos Mexicanos todas las personas gozarán de los derechos humanos reconocidos en esta Constitución y en los tratados internacionales de los que el Estado Mexicano sea parte, así como de las garantías para su protección, cuyo ejercicio no podrá restringirse ni suspenderse, salvo en los casos y bajo las condiciones que esta Constitución establece.

Las normas relativas a los derechos humanos se interpretarán de conformidad con esta Constitución y con los tratados internacionales de la materia favoreciendo en todo tiempo a las personas la protección más amplia.

Todas las autoridades, en el ámbito de sus competencias, tienen la obligación de promover, respetar, proteger y garantizar los derechos humanos de conformidad con los principios de universalidad, interdependencia, indivisibilidad y progresividad. En consecuencia, el Estado deberá prevenir, investigar, sancionar y reparar las violaciones a los derechos humanos, en los términos que establezca la ley“. ...

DE FUNDAR Y MOTIVAR SUS ACTOS".

${ }^{25}$ Véase el artículo 233 de la Ley Orgánica del Poder Judicial de la Federación.

${ }^{26}$ Véase el artículo 86, fracción I, párrafo segundo, de la CPEUM.

${ }^{27}$ Aunque ya había tendencias anteriores hacia una visión tuitiva de los derechos humanos, desde la reforma constitucional de inicios de los noventas del siglo pasado, referente a la creación de comisiones nacional y estaduales de derechos humanos, la creación de algunas leyes federales y estaduales de tutela a dichos derechos, e incluso a partir de algunos casos judiciales, como el "Mini Numa" (ver sentencia de amparo indirecto del expediente 1157/2007-II, pronunciada el 11 de julio de 2008 por el juez Séptimo de Distrito en el Estado de Guerrero), en donde se dio procedencia a la justiciabilidad del derecho social de acceso a la salud.

${ }^{28}$ Cfr. Díaz Romero, Juan, Comentarios a las reformas constitucionales de 2011 sobre derechos humanos y juicio de amparo, en Ensayos y conferencias de los forjadores de la Suprema Corte de Justicia de la Nación, Ed. Suprema Corte de Justicia de la Nación, ed. 1ª , México, 2012, p. 29. ${ }^{29}$ Antes, decía: “...todo individuo gozará de las garantías que otorga esta Constitución, las cuales no podrán restringirse ni suspenderse, sino en los casos y con las condiciones que ella misma establece..." 
En esas condiciones se observa que el actual prototipo se estructura claramente como tuitivo de los derechos humanos desde la propia Constitución, pues el texto antes consignado, amén de instaurar criterios hermenéuticos en relación a esos derechos (pro persona, interpretación conforme, y los principios de universalidad, interdependencia, indivisibilidad y progresividad), instituye garantías primarias y secundarias genéricas ${ }^{30}$ respecto de los derechos humanos, al constreñir a "todas las autoridades, en el ámbito de sus competencias", a "promover, respetar, proteger y garantizar" dichos derechos, estableciendo en consecuencia la obligación de "prevenir, investigar, sancionar y reparar las violaciones a los derechos humanos, en los términos que establezca la ley". Así, se ha instaurado una tutela ex officio de los derechos humanos.

En sede judicial, dicha tutela ha impactado, por una parte, en la aplicación de los citados criterios hermenéuticos, y atento a ello, por ejemplo, se ha reconocido la fuerza vinculante de la jurisprudencia de la Corte Interamericana de Derechos Humanos ${ }^{31}$ (quedando excluidas de esa vinculación, como respecto de la jurisprudencia interna, las autoridades legislativas y administrativas ${ }^{32}$ ); también ha tenido impacto en el control de regularidad constitucional ${ }^{33}$, que ha mutado de un sistema concentrado a un sistema dual (control concentrado y control difuso $\left.{ }^{34}\right)$.

\footnotetext{
${ }^{30}$ Desde luego, amén de otras garantías que puedan preverse en las normas secundarias o incluso en las políticas públicas.

${ }^{31}$ En adelante CoIDH.

${ }^{32}$ Véase la tesis jurisprudencial P./J. 21/2014 (10a.), registro 2006225, emitida en la décima época por la el Pleno de la SCJN, bajo la ponencia del ministro Arturo Zaldívar Lelo de Larrea, cuyo rubro dice: "JURISPRUDENCIA EMITIDA POR LA CORTE INTERAMERICANA DE DERECHOS HUMANOS. ES VINCULANTE PARA LOS JUECES MEXICANOS SIEMPRE QUE SEA MÁS FAVORABLE A LA PERSONA".

${ }^{33}$ Integrada por un parámetro que conforman los derechos humanos contenidos tanto en la Constitución como en los Tratados Internacionales. Véase la tesis jurisprudencial P./J. 20/2014 (10a.), registro 2006224, emitida en la décima época por el Pleno de la SCJN, bajo la ponencia del ministro Arturo Zaldívar Lelo de Larrea, de rubro "DERECHOS HUMANOS CONTENIDOS EN LA CONSTITUCIÓN Y EN LOS TRATADOS INTERNACIONALES. CONSTITUYEN EL PARÁMETRO DE CONTROL DE REGULARIDAD CONSTITUCIONAL, PERO CUANDO EN LA CONSTITUCIÓN HAYA UNA RESTRICCIÓN EXPRESA AL EJERCICIO DE AQUÉLLOS, SE DEBE ESTAR A LO QUE ESTABLECE EL TEXTO CONSTITUCIONAL".

${ }^{34}$ Esto derivado del contenido del párrafo tercero del artículo 1 constitucional ("Todas las autoridades, en el ámbito de sus competencias, tienen la obligación de promover, respetar, proteger y garantizar los derechos humanos..."), en interpretación sistemática con el numeral 133 constitucional ("Esta Constitución, las leyes del Congreso de la Unión que emanen de ella y todos los Tratados que estén de acuerdo con la misma, celebrados y que se celebren por el Presidente de la República, con aprobación del Se-
} 
Ahora, en lo que se refiere a las autoridades administrativas, la tutela ex officio de los derechos humanos se ha situado en la aplicación de los ya referidos criterios hermenéuticos; pero se ha dicho que también debiera situarse en el control difuso de regularidad constitucional, invocando al efecto el contenido del artículo 128 de la CPEUM, que prescribe que "todo funcionario público, sin excepción alguna, antes de tomar posesión de su encargo, prestará la protesta de guardar la Constitución y las leyes que de ella emanen".

Para robustecer esa idea, se ha destacado la existencia de dos precedentes emitidos hace tiempo por el Pleno de la SCJN, que disponen respectivamente, que "sobre todas las leyes y sobre todas las circulares, debe prevalecer siempre el imperio de la Carta Magna, y cuantas leyes secundarias se opongan a lo dispuesto en ella, no deben ser obedecidas por autoridad alguna" 35 , y que la Constitución "es la Ley Suprema de la Unión y a ella deben sujetarse todas las autoridades del país, a pesar de las disposiciones en contrario que pueda haber en las Constituciones y leyes de los Estados". ${ }^{36}$

nado, serán la Ley Suprema de toda la Unión. Los jueces de cada Estado se arreglarán a dicha Constitución, leyes y tratados, a pesar de las disposiciones en contrario que pueda haber en las Constituciones o leyes de los Estados."). Véase también la tesis aislada P. LXX/2011 (9a.), registro 160480, emitida en la 9a época por el Pleno de la SCJN, de rubro: “SISTEMA DE CONTROL CONSTITUCIONAL EN EL ORDEN JURÍDICO MEXICANO", bajo la ponencia la ministra Margarita Beatriz Luna Ramos, encargándose del engrose el ministro José Ramón Cossío Díaz, cuyo texto a la letra dice: "Actualmente existen dos grandes vertientes dentro del modelo de control de constitucionalidad en el orden jurídico mexicano, que son acordes con el modelo de control de convencionalidad ex officio en materia de derechos humanos a cargo del Poder Judicial. En primer término, el control concentrado en los órganos del Poder Judicial de la Federación con vías directas de control: acciones de inconstitucionalidad, controversias constitucionales y amparo directo e indirecto; en segundo término, el control por parte del resto de los jueces del país en forma incidental durante los procesos ordinarios en los que son competentes, esto es, sin necesidad de abrir un expediente por cuerda separada. Ambas vertientes de control se ejercen de manera independiente y la existencia de este modelo general de control no requiere que todos los casos sean revisables e impugnables en ambas. Es un sistema concentrado en una parte y difuso en otra, lo que permite que sean los criterios e interpretaciones constitucionales, ya sea por declaración de inconstitucionalidad o por inaplicación, de los que conozca la Suprema Corte para que determine cuál es la interpretación constitucional que finalmente debe prevalecer en el orden jurídico nacional. Finalmente, debe señalarse que todas las demás autoridades del país en el ámbito de sus competencias tienen la obligación de aplicar las normas correspondientes haciendo la interpretación más favorable a la persona para lograr su protección más amplia, sin tener la posibilidad de inaplicar o declarar su incompatibilidad".

${ }^{35}$ Véase la tesis aislada, registro 289870, emitida por el Pleno de la SCJN en la $5^{a}$ época, de rubro "CONSTITUCION, IMPERIO DE LA" (la publicación no menciona el nombre del ponente).

${ }^{36}$ Véase la tesis aislada, registro 291019, emitida por el Pleno de la SCJN en la $5^{\text {a }}$ época, 
Además, existe un criterio judicial reciente que posibilita, en un caso determinado de verificación sanitaria (en sede administrativa), la desaplicación de una norma contraria a derechos fundamentales, el cual a la letra dice: ${ }^{37}$

Con base en los artículos 1o., 14 y 17 de la Constitución Política de los Estados Unidos Mexicanos, 14, numeral 1, del Pacto Internacional de Derechos Civiles y Políticos, 8, numeral 1 y 25, numeral 1, de la Convención Americana sobre Derechos Humanos, así como de la interpretación que de unos y otros han realizado la Suprema Corte de Justicia de la Nación y la Corte Interamericana de Derechos Humanos, se advierte que: 1. Todas las autoridades están obligadas a promover, respetar, proteger y garantizar los derechos humanos, conforme a los principios de universalidad, interdependencia, indivisibilidad y progresividad, y en la interpretación de las normas relativas a aquéllos, debe favorecerse a las personas la protección más amplia; 2 . Todos los órganos jurisdiccionales están obligados a realizar interpretación conforme de los derechos humanos y, en su caso, desaplicar la norma violatoria; 3. El Estado Mexicano reconoce el derecho humano de acceso efectivo a la justicia, interrelacionado con el de defensa adecuada, que implica respeto a las formalidades esenciales del procedimiento, aun ante la omisión legislativa de preverlas; 4. Los Estados deben adecuar su derecho interno a sus obligaciones convencionales, entre ellas, la de contar con recursos efectivos que respeten las garantías del debido proceso, que no se aplican solamente a Jueces, tribunales o procesos judiciales; y, 5. La efectividad del recurso no imposibilita exigir formalidades o presupuestos, pero no debe supeditar el acceso a la justicia a requisitos innecesarios, excesivos o carentes de razonabilidad o proporcionalidad, además, el recurso debe ser idóneo y útil. Por su parte, el artículo 401 Bis, fracción VI³ ${ }^{38}$ de la Ley

de rubro "CONSTITUCION DE 1917" (la publicación no menciona el nombre del ponente).

${ }^{37}$ Véase la tesis IV.2o.A.68 A (10a.), registro 2005022 emitida en la $10^{a}$ época por el Segundo Tribunal Colegiado en Materia Administrativa del Cuarto Circuito, bajo la ponencia del magistrado Hugo Alejandro Bermúdez Manrique, de rubro "VERIFICACIÓN SANITARIA. PARA RESPETAR EL DERECHO HUMANO DE ACCESO A LA JUSTICIA, LA AUTORIDAD DEBE DESAPLICAR EL ARTÍCULO 401 BIS, FRACCIÓN VI, DE LA LEY GENERAL DE SALUD, QUE ESTABLECE QUE ANTE LA OMISIÓN DE ACOMPAÑAR EL ORIGINAL DEL ANÁLISIS PARTICULAR DE LA MUESTRA OBTENIDA EN LA VISITA RELATIVA Y, EN SU CASO, DE LA MUESTRA TESTIGO, NO SE DARÁ TRÁMITE A LA IMPUGNACIÓN DEL RESULTADO DEL ANÁLISIS OFICIAL, EL CUAL QUEDARÁ FIRME Y, PREVIO A DECIDIR, PREVENIR AL INTERESADO PARA QUE LAS EXHIBA".

${ }^{38}$ Que dice:

“Artículo 401 Bis.- La recolección de muestras se efectuará con sujeción a las siguientes reglas:

VI. Con la impugnación a que se refiere la fracción anterior, el interesado deberá acompañar el original del análisis particular que se hubiere practicado a la muestra que haya sido dejada en poder de la persona con quien se entendió la diligencia de muestreo, así como en su caso, la muestra testigo. Sin el cumplimiento de este requisito no se dará trámite a la impugnación y el resultado del análisis oficial quedará firme; ..." 
General de Salud, no permite sino una única interpretación literal, en el sentido de que ante la omisión de acompañar el original del análisis particular de la muestra obtenida en una visita de verificación sanitaria y, en su caso, de la muestra testigo, procede, como consecuencia inmediata, que no se dé trámite a la impugnación ${ }^{39}$ del análisis oficial y su resultado quede firme, con las repercusiones perjudiciales o sancionatorias que ello implique. No obstante, esa interpretación no es permisible en atención al derecho humano que está en juego (acceso a la justicia), porque la consecuencia no es proporcional a la acción humana ocurrida, ya se trate de un simple error de distracción del interesado al equivocarse en el juego de documentos a entregar o, incluso, la ignorancia de la norma, lo cual conlleva la pérdida de eficacia impugnativa, que implicará a su vez (salvo errores formales atacables en otra vía), la vinculación de la sanción impuesta, por lo que tal consecuencia es carente de correspondencia. Tampoco se estima razonable, pues no es admisible, equilibrado o aceptable que se desconozca la falibilidad humana en cuestiones menores, cuando la consecuencia resulta grave, pues se estima que lo armonioso con dicha falibilidad, que es inherente a la persona y a la labor de la autoridad de la vigilancia sanitaria, sería precisamente la posibilidad de enmendar el error, cuando no existe razón para negar esa oportunidad. Por tanto, para respetar el derecho fundamental de acceso a la justicia, la autoridad debe desaplicar tal porción normativa y, previo a decidir si tiene o no por interpuesta la impugnación, prevenir al interesado para que exhiba el original del análisis particular y/o la muestra testigo, conforme al artículo $17 \mathrm{~A}^{40}$ de la Ley Federal de Procedimiento Administrativo, de aplicación supletoria, según lo prevé su dispositivo 2.

\footnotetext{
${ }^{39}$ Respecto de impugnaciones, en sede administrativa, la Ley General de Salud dice: "artículo 438.- Contra actos y resoluciones de las autoridades sanitarias que con motivo de la aplicación de esta Ley den fin a una instancia o resuelvan un expediente, los interesados podrán interponer el recurso de inconformidad".

40 "Artículo 17-A.- Cuando los escritos que presenten los interesados no contengan los datos o no cumplan con los requisitos aplicables, la dependencia u organismo descentralizado correspondiente deberá prevenir a los interesados, por escrito y por una sola vez, para que subsanen la omisión dentro del término que establezca la dependencia $u$ organismo descentralizado, el cual no podrá ser menor de cinco días hábiles contados a partir de que haya surtido efectos la notificación; transcurrido el plazo correspondiente sin desahogar la prevención, se desechará el trámite.

Salvo que en una disposición de carácter general se disponga otro plazo, la prevención de información faltante deberá hacerse dentro del primer tercio del plazo de respuesta o, de no requerirse resolución alguna, dentro de los diez días hábiles siguientes a la presentación del escrito correspondiente. La fracción de día que en su caso resulte de la división del plazo de respuesta se computará como un día completo. En caso de que la resolución del trámite sea inmediata, la prevención de información faltante también deberá hacerse de manera inmediata a la presentación del escrito respectivo.

De no realizarse la prevención mencionada en el párrafo anterior dentro del plazo aplicable, no se podrá desechar el trámite argumentando que está incompleto. En el supuesto de que el requerimiento de información se haga en tiempo, el plazo para que la dependencia correspondiente resuelva el trámite se suspenderá y se reanudará a partir del día hábil inmediato siguiente a aquel en el que el interesado conteste."
} 
No obstante, la tutela ex officio de los derechos humanos en sede administrativa ha sido reducida al ámbito hermenéutico por interpretación judicial reciente del Pleno de la SCJN, el cual ha dicho en una tesis aislada que esas autoridades "en el ámbito de sus competencias, deben aplicar las normas correspondientes haciendo la interpretación más favorable a la persona para lograr su protección más amplia, sin que estén facultadas para inaplicarlas o declarar su inconstitucionalidad" 41 ; afirmando no ser óbice a lo anterior el contenido del artículo noveno transitorio del decreto de reforma constitucional del 10 de junio de 2011, que dice: "se derogan todas las disposiciones que contravengan el presente decreto", pues dicha tesis postula que "las autoridades administrativas no están facultadas para inaplicar normas por considerarlas derogadas por el citado precepto transitorio, aun en el supuesto de que las estimen contrarias a los derechos humanos" ${ }^{42}$. Criterio que ha sido reafirmado, ahora por la Segunda Sala de la SCJN, en otro precedente aislado, al disponer que: ${ }^{43}$

El artículo 1o. de la Constitución Política de los Estados Unidos Mexicanos establece que todas las autoridades, en el ámbito de sus competencias, deben cumplir con una serie de obligaciones en materia de derechos humanos. Sin embargo, en términos de la tesis P. LXIX/2011 (9a.) $\left(^{*}\right)$, del Tribunal Pleno de la Suprema Corte de Justicia de la Nación, las autoridades administrativas no están facultadas para realizar algún tipo de control constitucional, sea concentrado o difuso; es decir, no pueden declarar la invalidez de un determinado precepto e inaplicarlo, ni siquiera bajo el argumento de una reparación de derechos humanos, ya que ello implicaría desatender los requisitos de procedencia señalados por las leyes para interponer un medio de defensa, y que deben cumplirse de manera previa a un pronunciamiento de fondo del asunto. En todo caso, han de interpretar las disposiciones jurídicas en el sentido más favorable a las personas, pero sin que ello llegue a descuidar las facultades y funciones que deben desempeñar en atención a sus ámbitos

\footnotetext{
${ }^{41}$ Véase la tesis aislada P. VII/ 2014 (10a.), registro 2005879, emitida en la 10ª época por el Pleno de la SCJN, bajo la ponencia del ministro José Fernando Franco González Salas (en su ausencia hizo suyo el asunto el ministro Alberto Pérez Dayán), de rubro "AUTORIDADES ADMINISTRATIVAS. NO ESTÁN FACULTADAS PARA INAPLICAR NORMAS QUE ESTIMEN DEROGADAS POR EL ARTÍCULO NOVENO TRANSITORIO DEL DECRETO DE REFORMA CONSTITUCIONAL PUBLICADO EN EL DIARIO OFICIAL DE LA FEDERACIÓN EL 10 DE JUNIO DE 2011".

${ }^{42}$ Ídem.

${ }^{43}$ Véase la tesis aislada 2a. CIV/ 2014 (10a.), registro 2007573, emitida en la 10ª época por la Segunda Sala de la SCJN, bajo la ponencia del ministro José Fernando Franco González Salas, de rubro "CONTROL CONSTITUCIONAL CONCENTRADO O DIFUSO. LAS AUTORIDADES ADMINISTRATIVAS NO ESTÁN FACULTADAS PARA REALIZARLO".
} 
competenciales. Aceptar lo contrario, generaría incertidumbre jurídica en franca contravención a otros derechos humanos como los de legalidad, debido proceso y seguridad jurídica, previstos en los artículos 14 y 16 constitucionales.

Se destaca que a pesar de que los últimos dos criterios expuestos son precedentes aislados, no vinculantes, en la práctica han primado, quizá por su producción reciente y por provenir del más alto tribunal de la Nación.

\section{La autoridad administrativa frente a la tutela de los derechos humanos en el sistema interamericano}

\section{La Convención Americana sobre Derechos Humanos ${ }^{44}$, en su artículo 2 instituye:}

Artículo 2. Deber de Adoptar Disposiciones de Derecho Interno

Si el ejercicio de los derechos y libertades mencionados en el Artículo $1^{45}$ no estuviere ya garantizado por disposiciones legislativas o de otro carácter, los Estados Partes se comprometen a adoptar, con arreglo a sus procedimientos constitucionales y a las disposiciones de esta convención, las medidas legislativas o de otro carácter que fueren necesarias para hacer efectivos tales derechos y libertades.

Ahora, la jurisprudencia de la CoIDH ha establecido que "cuando un Estado es Parte de un tratado internacional como la Convención Americana, todos sus órganos, incluidos sus jueces, están sometidos a aquél, lo cual les obliga a velar por que los efectos de las disposiciones de la Convención no se vean mermados por la aplicación de normas contrarias a su objeto y fin" ${ }^{46}$; disponiendo en consecuencia que el deber de ejercer ex officio un "control de convencionalidad", respecto de la referida Convención "es función y tarea de cualquier autoridad

${ }^{44}$ En adelante $\mathrm{CADH}$

${ }^{45}$ El artículo 1 de la Convención dispone:

"Artículo 1. Obligación de Respetar los Derechos

1. Los Estados Partes en esta Convención se comprometen a respetar los derechos y libertades reconocidos en ella y a garantizar su libre y pleno ejercicio a toda persona que esté sujeta a su jurisdicción, sin discriminación alguna por motivos de raza, color, sexo, idioma, religión, opiniones políticas o de cualquier otra índole, origen nacional o social, posición económica, nacimiento o cualquier otra condición social.

2. Para los efectos de esta Convención, persona es todo ser humano".

${ }^{46}$ Véanse las sentencias de la CoIDH de 24 de febrero de 2011, fondo y reparaciones, Serie C, No. 221, párrafo 193, en el caso Gelman vs. Uruguay; de 26 de noviembre de 2010, excepción preliminar, fondo, reparaciones y costas, párrafo 225, relativa al caso Cabrera García y Montiel Flores vs. México; de 23 de noviembre de 2009, excepción preliminar, fondo, reparaciones y costas, Serie C No. 209, párrafo 339, relativa al caso Radilla Pacheco vs. México; y de 29 de noviembre de 2006, fondo, reparaciones y costas, Serie C, N. 162, párrafo 173, relativa al caso La Cantuta vs. Perú. 
pública y no sólo del Poder Judicial"47, lo anterior "evidentemente en el marco de sus respectivas competencias y de las regulaciones procesales correspondientes" ${ }^{48}$, debiendo tener en cuenta al efecto no solamente el tratado, "sino también la interpretación que del mismo ha hecho la Corte Interamericana, intérprete última de la Convención Americana" ${ }^{49}$

Por otra parte, y tomando en consideración el carácter expansivo ${ }^{50}$ propio de los derechos humanos, la CoIDH ha determinado, con el evidente propósito de ampliar la tutela judicial en todos los supuestos, por ejemplo, que algunos de los derechos sobre garantías judiciales del artículo $8^{51}$ de la Convención Americana se deben aplicar también a las

${ }^{47}$ Véase caso Gelman vs. Uruguay, párrafo 239, referido en la nota al pie inmediata anterior.

${ }^{48}$ Ibídem, párrafo 193. Ver también caso Cabrera García y Montiel Flores vs. México, párrafo 225 , referido en la nota 47 supra.

${ }^{49}$ Véase caso Gelman vs. Uruguay, párrafo 193, referido en la nota 47 supra. Véanse también, entre otros precedentes de dicha Corte Interamericana, el párrafo 225, de la sentencia relativa al caso Cabrera García y Montiel Flores vs. México, referido en la nota 47 supra; la sentencia de 24 de noviembre de 2010, excepciones preliminares, fondo, reparaciones y costas, Serie C, No. 219, párrafo 176, relativa al caso Gomes Lund y otros (Guerrilha do Araguaia) vs. Brasil; el párrafo 339, relativa al caso Radilla Pacheco vs. México, referido en la nota 47 supra; la sentencia de 20 de noviembre de 2007, excepción preliminar, fondo, reparaciones y costas, Serie C, No. 169, párrafo 78, relativa al caso Boyce y otros vs. Barbados; el párrafo 173, de la sentencia relativa al caso La Cantuta vs. Perú, referido en la nota 47 supra; y la sentencia de 26 de septiembre de 2006, excepciones preliminares, fondo, reparaciones y costas, Serie C, No. 154, párrafo 124, relativa al caso Almonacid Arellano vs. Chile.

${ }_{50}$ Significa que el intérprete (generalmente el juez pero no sólo él) debe llevar la aplicación y determinación de los derechos humanos a su máxima expresión. Véase Carpizo, Enrique, Derechos fundamentales y la interpretación constitucional. La Corte y los derechos, Ed. Porrúa, ed. 1' , México, 2009, p. 110.

51 "Artículo 8. Garantías Judiciales

1. Toda persona tiene derecho a ser oída con las debidas garantías y dentro de un plazo razonable, por un juez o tribunal competente independiente e imparcial establecido con anterioridad por la ley, en la sustanciación de cualquier acusación penal formulada contra ella, o para la determinación de sus derechos y obligaciones de orden civil, laboral, fiscal o de cualquier otro carácter.

2. Toda persona inculpada de delito tiene derecho a que se presuma su inocencia mientras no se establezca legalmente su culpabilidad. Durante el proceso, toda persona tiene derecho, en plena igualdad, a las siguientes garantías mínimas:

a) derecho del inculpado de ser asistido gratuitamente por el traductor o intérprete, si no comprende o no habla el idioma del juzgado o tribunal;

b) comunicación previa y detallada al inculpado de la acusación formulada;

c) concesión al inculpado del tiempo y de los medios adecuados para la preparación de su defensa;

d) derecho del inculpado de defenderse personalmente o de ser asistido por un defensor de su elección o de comunicarse libre y privadamente con su defensor;

e) derecho irrenunciable de ser asistido por un defensor proporcionado por el Estado, remunerado o no según la legislación interna, si el inculpado no se defendiere por sí mismo ni nombrare defensor dentro del plazo establecido por la ley;

f) derecho de la defensa de interrogar a los testigos presentes en el tribunal y de obtener la comparecencia, como testigos o peritos, de otras personas que puedan arrojar luz sobre los hechos; 
decisiones de los órganos administrativos. ${ }^{52}$

Así, se observa que en el sistema interamericano, la autoridad administrativa (así como todas las demás autoridades), en el ámbito de su respectiva competencia, debe ejercer un control de convencionalidad ex officio, tomando al efecto como parámetro no solamente el texto de la CADH sino también la interpretación que de la misma ha hecho la CoIDH en su jurisprudencia.

V. Reflexiones a manera de conclusión, sobre la labor de la autoridad administrativa mexicana frente a su obligación tuitiva respecto de los derechos humanos

A manera de conclusión, a continuación se presentan algunas reflexiones derivadas de lo antes expuesto, bosquejando algunos temas que considero de interés respecto al tema en comento.

a) Casos de tutela de derechos humanos por particulares equiparables a autoridades administrativas, y casos de tutela por estas últimas en equiparación a particulares

Como se ha visto, en el sistema mexicano la autoridad administrativa es aquella que realiza actos administrativos unilaterales (individuales o generales) en un contexto de relaciones verticales de supra a subordinación; ya sea creando, modificando o extinguiendo situaciones jurídicas en forma unilateral y obligatoria, o bien omitiendo el acto que de realizarse crearía, modificaría o extinguiría dichas situaciones jurídicas.

Pero también se equipara a "autoridad administrativa" al particular que realiza actos administrativos equivalentes a los de autoridad (referidos en el párrafo que antecede), cuando sus funciones

g) derecho a no ser obligado a declarar contra sí mismo ni a declararse culpable, y h) derecho de recurrir del fallo ante juez o tribunal superior.

3. La confesión del inculpado solamente es válida si es hecha sin coacción de ninguna naturaleza.

4. El inculpado absuelto por una sentencia firme no podrá ser sometido a nuevo juicio por los mismos hechos.

5. El proceso penal debe ser público, salvo en lo que sea necesario para preservar los intereses de la justicia".

${ }^{52}$ Véanse, por ejemplo, los siguientes casos resueltos por la CoIDH: la sentencia de 31 de enero de 2001, fondo, reparaciones y costas, Serie C, No. 91, párrafo 70, relativa al caso Tribunal Constitucional vs. Perú; la sentencia de 2 de febrero de 2001, fondo, reparaciones y costas, Serie C, No. 72, párrafo 106, relativa al caso Baena Ricardo y otros vs. Panamá; la sentencia de 6 de febrero de 2001, fondo, reparaciones y costas, Serie C, No. 74, párrafo 103 relativa al caso Ivcher Bronstein vs. Perú); y la sentencia de 23 de noviembre de 2010, excepciones preliminares, fondo, reparaciones y costas, Serie C, No. 218, párrafos 108 y 132, relativa al caso Vélez Loor vs. Panamá. 
estén determinadas por una norma general ${ }^{53}$. En esos términos, ese particular deberá también, ex officio, "promover, respetar, proteger y garantizar" los derechos humanos, y en consecuencia "prevenir, investigar, sancionar y reparar" las violaciones a esos derechos. Todo ello, bajo las pautas hermenéuticas pro persona, interpretación conforme, y los principios de universalidad, interdependencia, indivisibilidad y progresividad.

Ahora, parece interesante observar además, en una especie de feedback, cuando la autoridad administrativa realiza actos contractuales en un contexto de relaciones horizontales de coordinación, ya que prima facie se equipara a un particular, pues formalmente actúa en un mismo plano, es decir, en igualdad y bilateralidad; pero cuando en ese tipo de relaciones despliega funciones determinadas en una norma general que conllevan a crear, modificar o extinguir situaciones jurídicas en forma unilateral y obligatoria, o bien cuando omite el acto que de realizarse crearía, modificaría o extinguiría dichas situaciones jurídicas, considero que retorna del status de particular para "equipararse" a autoridad, y en ese caso debiera también, ex officio, "promover, respetar, proteger y garantizar" los derechos humanos, y en consecuencia "prevenir, investigar, sancionar y reparar" las violaciones a dichos derechos, bajo las pautas hermenéuticas indicadas supralíneas. Un ejemplo de lo anteriormente expuesto podría ser la contratación de trabajadores (e incluso algunos otros actos patronales), originalmente anclada en el campo del derecho laboral-burocrático, pero en la que pueden darse violaciones a los derechos de igualdad y no discriminación. ${ }^{54}$

\footnotetext{
${ }^{53}$ Véase, por ejemplo, tesis aislada V.2o.P.A.8 A (10a.), registro 2007696, emitida en la $10^{a}$ época por el Segundo Tribunal Colegiado en materias penal y administrativa del Quinto Circuito, bajo la ponencia del magistrado Óscar Javier Sánchez Martínez, de rubro “AUTORIDAD PARA EFECTOS DEL JUICIO DE AMPARO. LO ES LA UNIVERSIDAD DE SONORA CUANDO PROPORCIONA INFORMACIÓN CON FUNDAMENTO EN LA LEY DE ACCESO A LA INFORMACIÓN PÚBLICA Y DE PROTECCIÓN DE DATOS PERSONALES DE LA ENTIDAD, ASÍ COMO EN SUS LINEAMIENTOS EN LA MATERIA".

${ }^{54}$ Véase, por analogía, lo resuelto en la sentencia de Amparo Directo en Revisión 992/ 2014 (quejosos y recurrentes: Rosario del Carmen Pacheco Mena y otros), pronunciada el 12 de noviembre de 2014, por la Primera Sala de la SCJN, respecto a los actos discriminatorios contenidos en convocatorias laborales, como ilícitos constitucionales atribuibles a particulares equiparados a autoridad. Mayoría de 4 votos de los señores Ministros Arturo Zaldívar Lelo de Larrea (Ponente), José Ramón Cossío Díaz, quien se reservó su derecho de formular voto concurrente, Olga Sánchez Cordero de García Villegas y Presidente Alfredo Gutiérrez Ortiz Mena, quien se reservó su derecho de formular voto concurrente, en contra del emitido por el señor Ministro Jorge Mario Pardo Rebolledo quien se reservó su derecho de formular voto particular. Véase también la tesis aislada 1a. XXXIII/ 2015 (10a.), registro 2008308, 10a época, emitida a propósito del
} 


\section{b) La obligatoriedad de la jurisprudencia para la autoridad administrativa como diseño normativo congruente con la tutela de los derechos humanos}

De la exposición descriptiva del sistema jurídico mexicano hecha con antelación, se aprecia que actualmente la jurisprudencia nacional sólo es vinculante para los órganos jurisdiccionales (salvo en materia electoral), en tanto que la jurisprudencia interamericana también vincula sólo a esos órganos, según interpretación jurisprudencial interna. ${ }^{55}$

Pero, en contrario, la jurisprudencia interamericana establece que la misma debe ser observada por todos los operadores, incluso por la autoridad administrativa, al disponer que el deber de ejercer ex officio un control de convencionalidad respecto de la $\mathrm{CADH}$ "es función y tarea de cualquier autoridad pública y no sólo del Poder Judicial... evidentemente en el marco de sus respectivas competencias y de las regulaciones procesales correspondientes", debiendo tener en cuenta al efecto no solamente el tratado, "sino también la interpretación que del mismo ha hecho la Corte Interamericana, intérprete última de la Convención Americana".

En ese sentido, la Convención de Viena sobre el derecho de los tratados dispone, en su artículo 27, que un Estado Parte "no podrá invocar las disposiciones de su derecho interno como justificación del incumplimiento de un tratado", y al respecto la CoIDH ha dicho que "cuando un Estado es Parte de un tratado internacional como la Convención Americana, todos sus órganos, incluidos sus jueces, están sometidos a aquél, lo cual les obliga a velar por que los efectos de las disposiciones de la Convención no se vean mermados por la aplicación de normas contrarias a su objeto y fin". ${ }^{56}$

caso antes referido (junto a otras 18 tesis), de rubro "DISCRIMINACIÓN EN EL ÁMBITO LABORAL. ANTE SU ACTUALIZACIÓN, EL JUZGADOR DEBERÁ DECLARAR LA NULIDAD DEL ACTO", cuyo texto, en lo que interesa dice: “... ante la presencia de un acto discriminatorio, la primera consecuencia que ello acarrea será la declaración de nulidad que sobre el mismo debe realizarse. En el ámbito laboral, lo anterior se traduce en que el acto discriminatorio debe ser declarado nulo, pues de lo contrario, se tendría que aceptar que a pesar de haber calificado un acto como discriminatorio y, por tanto, como violatorio de la Constitución, el mismo deba subsistir solamente por provenir de la libertad de contratación de que gozan las personas, ello a pesar de que los derechos de igualdad y no discriminación sí gozan de eficacia entre las relaciones entre particulares. Es por ello que la consecuencia directa e inmediata de la calificativa de un acto como discriminatorio, es la nulidad del mismo..."

${ }^{55}$ Ver la tesis jurisprudencial referida en la nota 33, supra.

${ }^{56}$ Ver nota 47, supra. 
En esa tesitura, considero que la jurisprudencia interamericana resulta ser de observancia obligatoria para la autoridad administrativa, dentro de su ámbito competencial; por tanto, debe formar parte del marco jurídico o parámetro de contraste relativo a la tutela de los derechos humanos a su cargo.

Pero resulta incongruente que, en línea paralela, las disposiciones jurisprudenciales internas transiten en sentido contrario al no ser vinculantes para dicha autoridad, por lo que estimo necesario establecer la observancia obligatoria de la jurisprudencia en sede nacional ${ }^{57}$, máxime cuando en una de las parcelas del derecho, la electoral, esto ya es así.

Ahora, es sabido que esta no vinculación de la jurisprudencia en sede administrativa, obedece en gran medida al influjo del "principio de relatividad" de las sentencias de amparo ${ }^{58}$.

Pero dicho principio ha sido atemperado, primero con la reforma constitucional de 1994 (al numeral 105) que posibilitó que las declaratorias de invalidez, en las controversias constitucionales $\mathrm{y}$ en las acciones de inconstitucionalidad, pudieran tener efectos generales si en su aprobación se obtenía la mayoría calificada de cuando menos 8 votos de los ministros del Pleno de la SCJN; y luego con la reforma del 6 de junio de 2011 al artículo 107 constitucional, que contempló la posibilidad de emisión de declaratorias generales de inconstitucionalidad por parte de la SCJN, cuando el Poder Judicial Federal estableciere jurisprudencia de inconstitucionalidad por reiteración, caso en que la referida Corte notificaría esto a la autoridad emisora, y transcurrido el plazo de 90 días naturales sin que fuere superado el problema de inconstitucionalidad, se emitiría la declaratoria general, siempre que fuere aprobada por una mayoría de cuando menos ocho votos de los ministros del referido Pleno.

\footnotetext{
${ }^{57}$ Sobre este tema mucho se ha dicho.

58 Conocida como "fórmula Otero" (atribuida a Mariano Otero), la cual en su momento fue tal vez la única forma de lograr que la Corte pudiera ejercer sus atribuciones para tutelar la Constitución y sus garantías, puesto que conciliaba los divergentes vectores entre la naturaleza del juicio de amparo, que entonces nacía, y el supuesto desequilibrio entre los Poderes de la Unión, en una época en que tal prudencia era efectivamente necesaria, consistiendo el punto medio resultante, que la Corte no derogaría normas merced a dichas facultades, sino que se limitaría a amparar y proteger sólo en el caso concreto y únicamente sobre las partes litigiosas; continuando dicha fórmula cuando en el año de 1882, aparece la jurisprudencia en el sistema mexicano (en base a la propuesta de Ezequiel Montes e Ignacio Mariscal) y prevaleciendo aún hoy, con ciertas modulaciones, en la fracción II del artículo 107 Constitucional. Véase Acosta Romero, Miguel y Pérez Fonseca, Alfonso, Derecho jurisprudencial mexicano, Ed. Porrúa, ed. $3^{\mathrm{a}}$, México, 2002, pp. 187-188.
} 
Así, en un modelo tuitivo de los derechos humanos, cuya clave indica que los derechos de las personas priman sobre las soberanías de los estados y sobre los poderes del mismo, y en donde estos derechos se traducen en elementos objetivos que informan todo el ordenamiento jurídico, orientando a las restantes normas que cumplen funciones más específicas, la jurisprudencia debiera ser vinculante para todas las autoridades, pues de otra manera, en ese campo, y en lo que atañe a la autoridad administrativa, ésta termina ajustándose a un modelo paleopositivista de Estado Legislativo de Derecho, mientras que los órganos jurisdiccionales acomodan su frecuencia en un modelo de Estado Constitucional de Derecho, siendo por obviedad injusta y perniciosa dicha desintonía

\section{c) La interpretación y la integración de la norma en sede administrativa como tutela de los derechos humanos}

Como ha quedado expuesto, es incontrovertible la tutela ex officio de derechos humanos que debe realizar la autoridad aministrativa mediante la interpretación de las normas que aplica (bajo las multicitadas pautas hermenéuticas). Así el "promover, respetar, proteger y garantizar" los derechos humanos, y en consecuencia "prevenir, investigar, sancionar y reparar" las violaciones a dichos derechos, es articulado en papel de intérprete.

Ahora, interpretar es sin duda también resolver antinomias e integrar la norma. En el primer caso, si tomamos la idea de que a la autoridad administrativa le está vedada la desaplicación de la norma que infringe la regularidad constitucional, entonces tendremos que aceptar que está impedida para la solución de antinomias frente al texto de la Constitución o de los tratados, constriñendo su posibilidad resolutiva a cuestiones de legalidad y reglamentación (en donde sí desaplicará alguna de las normas en colisión, al utilizar los métodos hermenéuticos de jerarquía, especialidad, cronología, etc.).

En el segund caso, una vez delimitado el derecho humano a tutelar, cualquier vacío normativo debiera ser integrado por la autoridad administrativa del conocimiento, acorde a las pautas hermenéuticas de referencia, a efecto de no hacer nugatorio dicho derecho.

Ahora, aunque es controvertida la posibilidad de que la autoridad administrativa pueda desaplicar normas en tutela ex officio de derechos humanos, habría que reflexionar si ese debate ha de prevalecer aún respecto de normas reglamentarias, circulares, memorandos, etc., producidos por el propio ente administrativo, pues esto implica, desde 
otro ángulo, más bien una revocación de sus propias determinaciones generales respecto la tutela en particular de un derecho de esa categoría.

Y más allá de atavismos culturales o desconfianza en el propio sistema impugnativo y sancionador , habría que seguir reflexionando, seria y responsablemente, en la posibilidad de que la autoridad administrativa pueda desaplicar cualquier norma en tutela de los derechos humanos y en la realización de la función objetiva de tales derechos.

Finalmente, es importante poner de relieve que cualquier "exceso" de la autoridad administrativa en la interpretación, o integración de la norma, o incluso en la desaplicación/revocación de las normas dictadas por ella misma, puede ser solucionado mediante el elenco de medios de impugnación diseñados en el sistema mexicano, amén del régimen sancionador administrativo y/o penal aplicable.

\section{d) La promoción de los derechos humanos como mecanismo para su tutela}

Ahora bien, un tema rezagado en la práctica es el deber de promoción de los derechos humanos en el ámbito competencial de la autoridad tutora de los mismos.

De acuerdo al diccionario de la Real Academia Española , el término promover significa "impulsar el desarrollo o la realización de algo"; en ese sentido, la autoridad administrativa está constreñida a impulsar el desarrollo o la realización de los derechos humanos.

Una dimensión de este deber se encuentra en la difusión que ha de darse para que las personas conozcan esos derechos así como sus garantías; y otra dimensión puede ubicarse en la obligación de establecer programas y políticas públicas para impulsar el desarrollo o la realización de los pluricitados derechos.

En estas condiciones se considera que la autoridad administrativa debe difundir los referidos derechos en el más amplio sentido, y diseñar las políticas públicas que impulsen su desarrollo o realización, para cumplir con el imperativo constitucional de promoción a tales prerrogativas. 


\section{REFERENCIAS}

\section{Bibliográficas}

Acosta Romero, Miguel y Pérez Fonseca, Alfonso, Derecho jurisprudencial mexicano, Ed. Porrúa, ed. 3ª , México, 2002.

CARPIZO, ENRIQUE, Derechos fundamentales y la interpretación constitucional. La Corte y los derechos, Ed. Porrúa, ed. 1ª , México, 2009. Cilia López, José Francisco, Los derechos humanos y su repercusión en el control de constitucionalidad y de convencionalidad, Ed. Porrúa, ed. 1a, México, 2015.

Díaz Romero, Juan, Comentarios a las reformas constitucionales de 2011 sobre derechos humanos y juicio de amparo, en Ensayos y conferencias de los forjadores de la Suprema Corte de Justicia de la Nación, Ed. Suprema Corte de Justicia de la Nación, ed. 1ª , México, 2012.

Ferrajoli, Luigi, Derechos y Garantías. La ley del más débil, Ed. Trotta, ed. 7 , Madrid, España, 2010.

Suprema Corte de Justicia de la NAción, La protección no jurisdiccional de los derechos humanos, Ed. Suprema Corte de Justicia de la Nación, ed. 1a, México, 2008.

Derechos Humanos. Parte General,

t. 1, Ed. Suprema Corte de Justicia de la Nación, ed. 1a, México, 2013.

TAPIA Vega, RicARdo, et al (coordinadores), Hacia el ámbito del derecho privado, de la serie Temas Selectos, vol. 2, Ed. Eternos Malabares-UAEM, México, 2015.

\section{Normativas Mexicanas}

Constitución Política de los Estados Unidos Mexicanos.

Ley de Amparo.

Código Civil Federal.

Ley reglamentaria de las fracciones I y II del artículo 105 de la Constitución Política de los Estados Unidos Mexicanos.

Ley Orgánica del Poder Judicial de la Federación.

Ley General de Salud.

Ley Federal de Procedimiento Administrativo.

Sentencia de amparo indirecto del expediente 1157/2007-II, pronunciada el 11 de julio de 2008 por el juez Séptimo de Distrito en el Estado de Guerrero. Sentencia de Amparo Directo en Revisión 992/2014, pronunciada el 12 de noviembre de 2014, por la Primera Sala de la Suprema Corte de Justicia de la Nación. 


\section{Tratados}

Convención Americana sobre Derechos Humanos

Convención de Viena sobre el derecho de los tratados

\section{Comparadas}

Constitución Política del Estado Plurinacional de Bolivia.

Código Civil Español.

Código Civil Argentino.

Sentencia de 25 de febrero de 1975 pronunciada por el Tribunal Constitucional de la República Federal Alemana.

Sentencia 53/1985 pronunciada por el Pleno del Tribunal Constitucional de España.

Fallo contenido en el EXP. N 3330-2004-AA/TC, relativo al caso Ludesminio Loja Mori, resuelto por el Pleno del Tribunal Constitucional de Perú.

\section{Electrónicas}

s/a, El acto administrativo, p. 125, visible en el sitio de internet: http:/ / biblio.juridicas.unam.mx/libros/4/1920/10.pdf (consultado el 15 de octubre de 2015).

Sitio de internet: http://www.cndh.org.mx/Que_Son_Derechos_ Humanos (consultado el 11 de octubre de 2015).

Sitio de internet: http://www.ohchr.org/SP/Issues/Pages/ WhatareHumanRights.aspx (consultado el 11 de octubre de 2015).

Sitio de internet: http://dle.rae.es $/ \mathrm{w}=$ promover $\& \mathrm{~m}=$ form $\& \mathrm{o}=\mathrm{h}$ (consultado el 3 de noviembre de 2015).

Sitio de internet de consulta de jurisprudencia mexicana: http:/ / sjf. scjn.gob.mx/sjfsist/Paginas/Tesis.aspx (consultado hasta el 3 de noviembre de 2015).

Sitio de internet de consulta de jurisprudencia de la CoIDH: http:/ / www.corteidh.or.cr/index.php/jurisprudencia (consultado hasta el 3 de noviembre de 2015). 


\section{El derecho fundamental a una Buena Administración Pública en México \\ Juan Manuel Ortega Maldonado*}

Resumen: La Buena Administración Pública no sólo es un objetivo programático que se contiene en la Constitución, sino que hoy día alcanza el nivel de Garantía y Derecho humano, en la medida que a través de ella se logrará la realización plena de otros Derechos fundamentales, como el de una vida digna de las personas. Este Derecho tiene un reconocimiento en la Constitución mexicana, aun cuando sea disperso en distintos artículos de la misma y, en nuestra opinión, puede ser exigible por cualquiera ante los tribunales.

Palabras clave: Derechos fundamentales; Derecho humanos; garantías de los derechos humanos; buena administración pública; derecho a la buena administración.

Abstract: Good governance is not only a policy objective that is contained in the Constitution, but today reaches the level of guarantee and human right to the extent that through it the full realization of other fundamental rights will be achieved, as the a decent life for people. This law has an appreciation in the Mexican Constitution, even if it is scattered in various articles of the same and, in our opinion, may be enforced by any court

\footnotetext{
* Doctor en Derecho por la Universidad Nacional Autónoma de México; Doctor en Derecho por la Universidad Complutense de Madrid, España. Profesor investigador de tiempo completo en la Facultad de Derecho y Ciencias Sociales de la Universidad Autónoma del Estado de Morelos. Autor en diversos artículos, revistas y libros.
} 
Key words: Fundamental rights; Human rights; guarantees of human rights; good governance; right to good administration.

\section{Introducción.}

Existe una marcada intención en diversas disposiciones jurídicas, para que las acciones de la Administración Pública sean eficaces y eficientes. En esa dirección apuntan diversos preceptos de la Constitución Federal, de algunos Tratados Internacionales, de distintas leyes ordinarias y de otros instrumentos legales, como el Plan Nacional de Desarrollo y los Programas Sectoriales, de todos los cuales nos ocuparemos en adelante. En esa misma línea la evaluación de las acciones de gobierno ha pasado de ser un concepto practicable sólo en el ámbito empresarial y por motivos de competencia, a una metodología en el funcionamiento normal de las instituciones públicas ${ }^{1}$.

La Buena Administración es desde hace tiempo un principio jurídico de la actuación administrativa. Pero lo interesante no es solamente identificar los contornos de este principio, sino subir un peldaño más y preguntarnos si los ciudadanos tienen derecho a determinados patrones o estándares en el funcionamiento de la Administración, es decir, si puede exigirse a la Administración Pública una Buena Administración. En otras palabras, si se tiene un "derecho fundamental a la Buena Administración".

La Administración Pública, en un país que se precie de democrático, no puede constituir una mera política sexenal que debe aplaudirse a tal o cual dirigente, sino una constante de la soberanía. Los responsables de dirigir la Administración deben tener claro que actuar correctamente y rendir cuentas al pueblo es una necesidad republicana y que el ímpetu por la calidad en el servicio debe presidir toda su actuación.

Este asunto no hubiese sido motivo de reflexión, sino es porque el artículo 1 constitucional nos obliga a hacerlo. En efecto, en su párrafo segundo y tercero se indica que las normas relativas a los derechos humanos se interpretarán de conformidad con esta Constitución y con los tratados internacionales de la materia favoreciendo en todo tiempo a las personas la protección más amplia y que todas las autoridades, en el ámbito de sus competencias, tienen la obligación de promover, respetar, proteger y garantizar los derechos humanos, de conformidad con los principios de universalidad, interdependencia, indivisibilidad y progresividad.

De lo anterior se sigue que para dar cabal cumplimiento a este postulado es necesario contar con una Buena Administración, es decir, una Administra-

${ }^{1}$ Cfr. Oropeza López, Alejandro; Evaluación de la función pública en México; Plaza y Valdés Editores; 2005, pp. 189-192. 
ción que reúna las características que enseguida indicaremos, que aplique los principios jurídicos que guían su funcionamiento y que respete las subgarantías que lo componen.

Hay ya algunos países que reconocen a la Buena Administración como Derecho fundamental y la razón es que con ella se busca precisamente el promover, respetar, proteger y garantizar otros derechos. Parece no haber duda de su carácter instrumental como "garantía" de otros derechos humanos.

Nada más cierto. Una Buena Administración está comprometida con la centralidad del ser humano, la participación ciudadana, la modernización permanente, la vinculación con la ética y la sensibilidad social.

Tal vez más que en otros tiempos, ahora, esa Administración se encuentra obligada con la mejora de vida de los ciudadanos. La perspectiva ética se incorpora así de lleno con una Buena Administración ${ }^{2}$.

\section{La Buena Administración como principio rector de la actuación pública.}

Una Buena Administración debe cumplir con las funciones que le marca la Constitución Federal, es decir, administrar con eficiencia, eficacia, economía, transparencia y honradez para satisfacer los objetivos ahí indicados.

Esos objetivos se cumplen cuando los servidores públicos se vinculan con el interés general. Lo que ahora decimos no es nada nuevo, pero sí necesario advertirlo en tiempos en los que las Administraciones Públicas no han servido al Pueblo, ni lo han hecho objetivamente, ni, mucho menos han velado por el interés general que es su fin y justificación ${ }^{3}$.

Desafortunadamente, la Buena Administración se encuentra secuestrada por los partidos políticos y son a ellos básicamente a los que ha servido en los últimos años. Se le ha encarcelado y desde ahí hemos contemplado cómo estos partidos controlan todos los poderes públicos y actúan arbitrariamente sin freno alguno.

Es así como puede entenderse que las Administraciones Públicas hayan crecido desmesuradamente: se hace preciso colocar a toda una legión de personas de procedencia política a las que se debe retribuir por servicios prestados al "partido". Las manifestaciones de la mala Administración Pública no se han hecho esperar.

\footnotetext{
${ }^{2}$ En ese sentido se ha apuntado que los servidores públicos alcanzan los objetivos y los fines que señala la ley, reglamentos y lo ordenado por la autoridad con base en la práctica de la deontología. Cfr. Cantarell Gamboa, Melvin; Ética y Deontología del Servidor Público; Hobiton Ediciones; México, 2001.

${ }^{3}$ En el mismo sentido Martínez Morales, Rafael; Derecho Administrativo, Primer Curso; Oxford University Press; México, 2011, p. 43.
} 
Este apoderamiento injustificado de la Buena Administración Pública explica el por qué la forma ordinaria del financiamiento público haya sido el endeudamiento especialmente en el ámbito local. En lugar de atender a las necesidades colectivas con los recursos existentes, se atiende a las necesidades del mantenimiento del poder. La negligencia, la ausencia de criterios éticos y la transformación del aparato administrativo en una colosal maquinaria de avasallamiento del contrincante político y del control social son las notas que caracterizan nuestro tiempo.

Son esos los motivos que orillan a un cambio sobre la visión de la Administración Pública. La reforma de dicha Administración en la democracia es un trabajo permanente, como lo es la promoción y protección de los derechos humanos.

Esto es así porque la construcción de una buena Administración tiene como objetivo principal la protección de las libertades básicas del ser humano. Teniendo como marco lo dicho, es claro que compete a la Administración el aseguramiento de que las aspiraciones personales y colectivas puedan hacerse realidad ${ }^{4}$.

Por eso, la Administración Pública debe ser un facilitador que fomente la dignidad de la persona y el ejercicio de todos sus derechos fundamentales, removiendo los obstáculos que impidan su efectivo cumplimiento.

A reserva de que podamos expandir lo antes comentado, es evidente que una Administración pública que actúe dentro de ese marco, debe tener en la mira el perfeccionamiento de los trámites, la transparencia, la simplificación administrativa, la modernización de su estructura, etcétera.

Y todo ello porque el centro de toda esa actuación pública -no debe perderse de vista- es el ciudadano, la persona, como sujeto de los derechos y obligaciones que la Constitución establece. Es a esa persona a quien la Administración pública sirve para que alcance la plenitud de su desarrollo.

No por nada, la Constitución Federal en el artículo 109 obliga a los servidores públicos a actuar dentro del margen de la legalidad, honradez, lealtad, imparcialidad y eficiencia en el desempeño de sus empleos, cargos o comisiones, sancionándolos en caso de acciones u omisiones que alteren estas obligaciones.

\section{Características de una Buena Administración}

Pasaremos revista a las principales características que, en nuestra opinión, debe tener una buena Administración Pública en un Estado Social y democrá-

4 Ferrajoli, Luigui; et. al.; Los fundamentos de los derechos fundamentales; Trota, 2001, p. 25. 
tico de Derecho: 1) la persona como centro de su finalidad; 2) objetividad; 3) participación ciudadana en la toma de decisiones; 4) modernización tecnológica al servicio del ciudadano; 5) vinculación ética y 6) sensibilidad social. Veamos.

\section{La persona como centro de la finalidad de la Administración Pública.}

Esta nota, en mi opinión, es la más destacada, pues lo que caracteriza al Estado de Derecho, en una democracia, es justamente el servicio a sus ciudadanos, su propensión hacia la mejora de su nivel de vida. Todo el actuar de la Administración debe tender hacia este punto.

En naciones donde la democracia es verdaderamente un estilo de vida, los ciudadanos no son sujetos inertes, sino activos en el diseño de las políticas públicas y en la dirección del interés general.

\section{Objetividad de la Administración Pública.}

Esto implica que la Administración ha de atender a las circunstancias sociales, económicas, culturales y políticas que impregnan su actuación. Desde esa realidad es posible la disposición permanente para corregir y rectificar lo que la experiencia nos muestra como desviaciones de los objetivos propuestos.

La Buena Administración debe necesariamente partir de la realidad pues sólo desde ella se puede mejorar el presente para construir el futuro.

3. Participación ciudadana en la toma de decisiones.

Si bien la persona, el ser humano ha desplazado al Estado, como centro de las preocupaciones de la Administración, lo cierto es que este enfoque no puede llevarse a cabo por una decisión caprichosa y personal del funcionario público, sino contando con la participación de su destinatario. La Buena Administración debe hacer de este ejercicio una práctica cotidiana.

Además, la Administración no puede atender sólo los intereses de un sector o grupo, sino la atención a los intereses de todos con moderación y a través de consensos. No puede hablarse en un Estado democrático de procurar sólo los intereses de las mayorías, pues esto significaría exclusivismos que son ajenos a la Buena Administración.

La determinación de los objetivos de las políticas públicas, por esa razón, no puede hacerse si no es desde la participación ciudadana. Se debe reconocer en la participación ciudadana un medio y un fin. Un medio para incidir en las políticas públicas y en el actuar diario de la Administración, y un fin, en sí mismo, para hacer realidad la democracia en las sociedades complejas de hoy día.

Aquella actuación pública que no procure una participación ciudadana, está condenada al fracaso, pues estaría carente de legitimidad al realizarse a espaldas de los propios ciudadanos. Pero esta participación, vale decirlo, no debe plantearse como un mero objetivo político o jurídico, sino como una práctica como método. 
La participación a la que se alude, debe tratarse de un diálogo que alimente mutuamente a la Administración y a los ciudadanos. Lo que no puede darse cuando existe una Administración poco receptiva y sensible para captar las necesidades colectivas e individuales.

Además, cuando se habla de participación ciudadana, debe subrayarse la libertad con la que se realiza. Debe entrañar una participación consciente e informada. La participación así vista, implica la integración plena del individuo en la sociedad o dicho de mejor manera, la posibilidad de desarrollo de las dimensiones sociales del individuo.

La solidaridad es una nota adicional de la participación. Debe quedar puesto de relieve que cuando hablamos de participación ciudadana debe entenderse también como la preocupación eficaz por los asuntos colectivos, en cuanto son de todos y van más allá de nuestros exclusivos intereses individuales. La participación es el modo más efectivo de la solidaridad social.

Es por esa misma razón que la Administración Pública debe buscar el diálogo con todos los actores sociales, sin excluir a ningún sector, lo cual acreditará la objetividad de la Administración en la toma de decisiones. Este diálogo no sólo debe servir para convencer, transmitir o comunicar las propuestas, sino especialmente para escuchar y contar con "buenas maneras"5.

\section{Modernización tecnológica al servicio del ciudadano}

Hablar de una Buena Administración conlleva la eficacia y eficiencia de su actuación, que sólo puede lograrse cuando aquélla tiene a su alcance la mejor tecnología, la más moderna. No sólo es suficiente tener como objetivo principal a la persona, actuar con objetividad y abrirse a la participación ciudadana, sino que también resulta menester contar con instrumentos tecnológicos que puedan operar en la realidad los objetivos trazados haciéndolo con eficacia y eficiencia.

La importancia que las modernas tecnologías de la información y la comunicación tienen para una Buena Administración son evidentes. Por ejemplo, el acceso a la información para el ciudadano, la transparencia que puede y debe realizar la Administración respecto de sus atribuciones y funciones, la participación electrónica que puede llevar a cabo el ciudadano y la simplificación de trámites que puede administrarse virtualmente.

Por supuesto que parte de esto ya existe en nuestros días. Así, tenemos las denominadas ventanillas únicas, la regulación en ley de la firma electrónica, la presentación de las declaraciones fiscales vía informática, el llenado electrónico de muchas solicitudes, etcétera.

Sin embargo, es necesario decirlo, falta aún mucho camino por recorrer para hacer realidad la "e-Administración", que garantice mayores niveles de eficacia, eficiencia y calidad de los servicios públicos.

\footnotetext{
${ }^{5}$ En ese sentido parece moverse de algún autor. Cfr. Gordillo, Agustín; Tratado de Derecho Administrativo, Tomo II. La Defensa del usuario y del administrado; Nota 28, p. 13-14
} 
Pero algo muy cierto es que para alcanzar esta fase de evolución tecnológica, no es suficiente que la Administración realice grandes inversiones en maquinaria y capacitación de su personal, sino que también es preciso que ese avance vaya de la mano del desarrollo tecnológico de la sociedad. De esa manera se puede cerrar la denominada "brecha digital" entre la sociedad y la Administración Pública.

Una nueva cultura, que sea a la vez humanista y apoyada en la tecnología es lo que permitiría hacer realidad una Buena Administración. Esta atmósfera de tecnología es la que permitirá mejorar los métodos del trabajo administrativo, los trámites, la prestación de servicios públicos.

Se debe trabajar paralelamente en dos frentes para mejorar este apartado: capacitación de los funcionarios públicos y educación en la sociedad.

\section{Vinculación ética.}

Existe un compromiso de la Administración Pública con le ética, tan es así que se ha publicado un Código de ética de los Servidores Públicos de la Administración Pública Federal, en el Diario Oficial de la Federación con fecha 31 de julio de 2002, que reconoce los siguientes principios para éstos: bien común, integridad, honradez, imparcialidad, justicia, transparencia, rendición de cuentas, entorno cultural y ecológico, generosidad, igualdad, respeto y liderazgo.

\section{Sensibilidad social}

Una de las características que define de mejor manera a la Buena Administración es la sensibilidad social que debe poseer. El palpar diariamente el sentir popular es básico para alcanzar esa meta que es la Buena Administración.

Ser sensible a las necesidades colectivas e individuales es requisito indispensable para la Administración; supone colocar a las personas en el centro de la actuación administrativa. Cuando se considera esto, la actuación administrativa presta servicios reales, al escuchar los intereses reales.

Esos servicios públicos, sin embargo, no son un fin, sino un medio para alcanzar mejores niveles de bienestar general. Son un medio para la mejora de las condiciones de ejercicio de la libertad solidaria de las personas, no un sistema de captación de voluntades.

Esto nos lleva a afirmar que las subvenciones como fin no son aceptables para una Buena Administración. Antes bien, atentan contra la misma pues se transforman en una rémora del desarrollo, en lugar de ser impulsoras del mismo.

\section{EI Derecho Fundamental a una Buena Administración Pública.}

Debemos partir de la afirmación de que el Derecho Administrativo actual tiene un objeto de estudio distinto al de antaño. Ha pasado de enfocar sus 
energías en los conceptos de autoridad, poder, privilegio de la administración, etcétera, al análisis del interés general, pero más específicamente, de la persona. Es ésta desde hace poco tiempo quien ocupa el papel estelar en todas las ciencias sociales y en el Derecho administrativo también.

Y también es por la persona que puede empezar a entenderse mejor este Derecho fundamental a la Buena Administración reconocido implícitamente en nuestra Carta Magna.

El individuo empieza a abandonar el rol de sujeto inerte frente al aparato estatal que dirigía casi toda su vida. Y aunque el poder sigue existiendo, debe ser ahora moderado, equilibrado, eficaz, eficiente, socialmente sensible, cooperativo y responsable.

Algo que parece se había olvidado, aunque se tenía presente, es que las Administraciones públicas existen porque existen intereses colectivos que atender, pero detrás de estos intereses comunes aparecen personas; luego entonces, son éstas las que explican, justifican y legitiman tanto la presencia como el buen funcionamiento de la Administración.

$\mathrm{Y}$ es por eso precisamente que la Buena Administración es un derecho ciudadano, un derecho fundamental o humano, porque las instituciones públicas y su funcionamiento son de ese ciudadano, de todos ellos. Se diseñan y estructuran para su procuración y, en consecuencia, son ellos los titulares de la democracia que subyace en esas instituciones.

Ahora bien, desde el ángulo normativo, debemos reconocer que no existe un precepto en la Constitución Federal Mexicana que aluda expresamente a este Derecho, -como sí se reconoce en el artículo 41 de la Carta de los Derechos Fundamentales de la Unión Europea ${ }^{6}$ - pero sostenemos que existe un reconocimiento implícito en ella, que puede extraerse de una armoniosa interpretación de los artículos 1, 25, 26, 69, 109, 113 y 134.

${ }^{6}$ CARTA DE LOS DERECHOS FUNDAMENTALES DE LA UNIÓN EUROPEA (2000/C 364/01). Artículo 41. Derecho a una buena administración.

1. Toda persona tiene derecho a que las instituciones y órganos de la Unión traten sus asuntos imparcial y equitativamente y dentro de un plazo razonable.

2. Este derecho incluye en particular: el derecho de toda persona a ser oída antes de que se tome en contra suya una medida individual que le afecte desfavorablemente, el derecho de toda persona a acceder al expediente que le afecte, dentro del respeto de los intereses legítimos de la confidencialidad y del secreto profesional y comercial, la obligación que incumbe a la administración de motivar sus decisiones.

3. Toda persona tiene derecho a la reparación por la Comunidad de los daños causados por sus instituciones o sus agentes en el ejercicio de sus funciones, de conformidad con los principios generales comunes a los Derechos de los Estados miembros.

4. Toda persona podrá dirigirse a las instituciones de la Unión en una de las lenguas de los Tratados y deberá recibir una contestación en esa misma lengua. 
De un estudio particular de estos artículos podemos derivar lo siguiente: el artículo 25 otorga al Estado la rectoría del desarrollo nacional, permitiendo "el pleno ejercicio de la libertad y la dignidad de los individuos, grupos y clases sociales, cuya seguridad protege la Constitución”. Al mismo tiempo, al regular la actuación de las empresas productivas del Estado, exige que se realice, utilizando las "mejoras prácticas"”.

Del artículo 26 se desprende que el Estado está obligado a la planeación y que en ella debe participar la sociedad en forma activa. En los planes y programas de la Administración pública, el individuo debe ser escuchado.

El artículo 69 es prueba clara que la Constitución está ocupada y preocupada por una Buena Administración. Se exige al Presidente de la República y a sus Secretarios de Despacho, informen a los representantes del Pueblo sobre la gestión de su Administración Pública. Son ellos los que hasta hoy, podían exigir una Buena Administración.

La Constitución ha elevado al máximo rango normativo (artículo 109-III) la sanción para aquellos funcionarios públicos que por sus actos u omisiones afecten la legalidad, honradez, lealtad, imparcialidad y eficiencia que deban observar en el desempeño de sus empleos, cargos o comisiones, llegando a crear un Sistema Nacional Anticorrupción (artículo 113). De estos artículos se exige una Buena Administración, so pena que pueda aplicarse a quien infrinja este propósito.

En igual sentido se mueve el artículo 134, que regula la manera en que las entidades públicas deben cuidar de los recursos económicos que administran. Se trata de la buena Administración de los recursos.

Pero aún hay más. Desde el ámbito internacional, el Estado mexicano ha suscrito distintos tratados que lo obligan a la Buena Administración y que se traducen, claro está, en derechos fundamentales para los ciudadanos. Nos referimos concretamente al artículo III, de la Convención Interamericana contra la Corrupción, que establece:

Artículo III

Medidas preventivas

A los fines expuestos en el Artículo II de esta Convención, los Estados Partes convienen en considerar la aplicabilidad de medidas, dentro de sus propios sistemas institucionales, destinadas a crear, mantener y fortalecer:

1. Normas de conducta para el correcto, honorable y adecuado cumplimiento de las funciones públicas. Estas normas deberán estar orientadas a prevenir conflictos de intereses y asegurar la preservación y el uso adecuado de los recursos asignados a los funcionarios públicos en el desempeño de sus funciones.

\footnotetext{
${ }^{7}$ Resulta interesante observar cómo la Procuraduría de la Defensa del Contribuyente (PRODE$\mathrm{CON}$ ), ha sugerido, desde un ángulo diferente, la adopción de "mejores prácticas administrativas" a las autoridades fiscales. Así, puede observarse los criterios emitidos por esta entidad y que aparecen publicados en su página electrónica.
} 
Establecerán también las medidas y sistemas que exijan a los funcionarios públicos informar a las autoridades competentes sobre los actos de corrupción en la función pública de los que tengan conocimiento. Tales medidas ayudarán a preservar la confianza en la integridad de los funcionarios públicos y en la gestión pública.

2. Mecanismos para hacer efectivo el cumplimiento de dichas normas de conducta.

3. Instrucciones al personal de las entidades públicas, que aseguren la adecuada comprensión de sus responsabilidades y las normas éticas que rigen sus actividades.

4. Sistemas para la declaración de los ingresos, activos y pasivos por parte de las personas que desempeñan funciones públicas en los cargos que establezca la ley y para la publicación de tales declaraciones cuando corresponda.

5. Sistemas para la contratación de funcionarios públicos y para la adquisición de bienes y servicios por parte del Estado que aseguren la publicidad, equidad y eficiencia de tales sistemas.

6. Sistemas adecuados para la recaudación y el control de los ingresos del Estado, que impidan la corrupción.

7. Leyes que eliminen los beneficios tributarios a cualquier persona o sociedad que efectúe asignaciones en violación de la legislación contra la corrupción de los Estados Partes.

8. Sistemas para proteger a los funcionarios públicos y ciudadanos particulares que denuncien de buena fe actos de corrupción, incluyendo la protección de su identidad, de conformidad con su Constitución y los principios fundamentales de su ordenamiento jurídico interno.

9. Órganos de control superior, con el fin de desarrollar mecanismos modernos para prevenir, detectar, sancionar y erradicar las prácticas corruptas.

10. Medidas que impidan el soborno de funcionarios públicos nacionales y extranjeros, tales como mecanismos para asegurar que las sociedades mercantiles y otros tipos de asociaciones mantengan registros que reflejen con exactitud y razonable detalle la adquisición y enajenación de activos, y que establezcan suficientes controles contables internos que permitan a su personal detectar actos de corrupción.

11. Mecanismos para estimular la participación de la sociedad civil y de las organizaciones no gubernamentales en los esfuerzos destinados a prevenir la corrupción.

12. El estudio de otras medidas de prevención que tomen en cuenta la relación entre una remuneración equitativa y la probidad en el servicio público.

Como puede observarse, se trata de medidas que si bien tienden a evitar la corrupción, en el fondo, no son más que medidas tendientes a mejorar a las Administraciones Públicas; reglas para una Buena Administración.

\section{Principios que guían el Derecho Fundamental a la Buena Adminis- tración}

El Derecho fundamental a la Buena Administración se concreta en una específica forma de llevar el Bien Público y se caracteriza, como ya lo indicamos, en centrar su fin en el individuo, en su objetividad, en la participación ciudadana, modernización tecnológica, su vinculación ética y su sensibilidad social. 
Ahora bien, en el marco de los procedimientos administrativos, este Derecho fundamental tiene apoyo en diversos principios generales que se desprenden de la propia Constitución y de la Ley Federal de Procedimiento Administrativo y que le permiten una precisa funcionalidad.

Esto principios tienen la virtualidad de fungir como mecanismos que facilitan la interpretación y aplicación de las reglas para una Buena Administración; entre estos principios están: 1. El de legalidad (art. 109-III, de la Const. Fed.); 2. Honradez (arts. 25, 109-III y 134, de la Const. Fed.); 3. Lealtad (art. 109-III, de la Const. Fed.); 4. Imparcialidad (art. 109-III, de la Const. Fed.). 5. Eficiencia (Arts. 25, 26, 69, 109, 113, y 134, de la Const. Fed.); 6. Eficacia (Arts. 25, 26, 69, 109, 113, y 134, de la Const. Fed.); 8. Transparencia y acceso a la información de interés general (arts. 25 y 134 de la Const. Fed.); 9. Responsabilidad (arts. 108, 109, 113 y 114, de la Const. Fed.); 10. Control y evaluación (arts. 25 y 69 de la Const. Fed.); 11, Rendición de cuentas (arts. 25 y 69 de la Const. Fed.); 12. Economía (arts. 134 de la Const. Fed., y 13 de la LFPA); 13. Celeridad (art 13 de la LFPA); 14. Publicidad (art 13 de la LFPA) y 15. Buena fe (art 13 de la LFPA).

\section{Derechos que integran el Derecho fundamental a la Buena Admi- nistración Pública.}

El Derecho fundamental a la Buena Administración Pública se concreta en los siguientes derechos que lo componen y que los ciudadanos pueden exigir ante los tribunales. Algunos de estos derechos fungen simultáneamente como principios jurídicos, en tanto pueden auxiliar en la interpretación y aplicación de ciertas reglas; pero al mismo tiempo juegan como derechos fundamentales, dado que pueden exigirse de la Administración pública. Estas subgarantías tienen su respaldo tanto en la Constitución Federal, como en diversos ordenamientos de menor rango, entre ellos podemos citar:

1. Derecho a que el acto administrativo se expida por órgano competente (arts. 16 constitucional y 3-I, de la Ley Federal de Procedimiento Administrativo, en adelante LFPA). 2. Derecho a que el acto cumpla fines de interés público y no fines distintos (arts. 16 constitucional y 3-III de la LFPA). 3. Derecho a que el acto conste por escrito y con firma de la autoridad que lo expida o que pueda expedirse en otra forma autorizada por la ley (arts. 16 constitucional y 3-IV, de la LFPA). 4. Derecho a la fundamentación y motivación de las actuaciones administrativas. (art. 16 constitucional y 3-V, de la Ley Federal de Procedimiento Administrativo). 5. Derecho a que el acto administrativo se expida sujetándose a las disposiciones relativas al procedimiento administrativo 
previstas en esta Ley (art 16 constitucional y 3-VII, de la LFPA). 6. Derecho a que el acto administrativo se expida sin que medie error sobre el objeto, causa o motivo, o sobre el fin del acto (arts. 16 constitucional y 3-VIII, de la LFPA). 7. Derecho a que el acto administrativo sea expedido sin que medie dolo o violencia en su emisión, (arts. 16 constitucional y 3-IX, de la LFPA). 8. Derecho a la mención de los recursos administrativos que procedan contra el acto administrativo recurrible, (arts. 17 constitucional y 3-XV, de la LFPA). 9. Derecho a que el acto administrativo sea expedido decidiendo expresamente todos los puntos propuestos por las partes o establecidos por la ley (arts. 17 constitucional y 4 de la LFPA). 10. Derecho a la publicación en el Diario Oficial de la Federación cuando se trate de actos administrativos de carácter general que puedan afectar a los ciudadanos. (arts. 16 constitucional y 4 de la LFPA). Etcétera.11. Derecho a la exigibilidad del acto administrativo (art 9 de la LFPA). 12. Derecho a iniciar de oficio el procedimiento administrativo (art. 14 de la LFPA). 13. Derecho a que la Administración Pública no exija mayores requisitos que los que expresamente establezca la ley (art. 15 de la LFPA). 14. Derecho a nombrar representante legal y personas autorizadas para recibir notificaciones y enterarse de los autos (art. 15 de la LFPA). 15. Derecho al acuse de recibo cuando se presenten documentos o promociones ante la autoridad administrativa (arts. 15-A-I y 16-IV, de la LFPA). 16. Derecho a que obren documentos cotejados de los originales en el expediente administrativo y no los originales (art. 15-A- II, de la LFPA). 17. Derecho a señalar los datos de identificación de los permisos, registros, licencias y, en general, de cualquier documento expedido por la dependencia u organismo descentralizado de la administración pública federal ante la que realicen el trámite, en lugar de entregar copia de los mismos (art. 15-A-III de la LFPA). 18. Derecho a no proporcionar datos o entregar juegos adicionales de documentos entregados previamente a la dependencia u organismo descentralizado de la administración pública federal ante la que realicen el trámite correspondiente, siempre y cuando señalen los datos de identificación del escrito en el que se citaron o con el que se acompañaron y el nuevo trámite lo realicen ante la propia dependencia u organismo descentralizado, aun y cuando lo hagan ante una unidad administrativa diversa, incluso si se trata de un órgano administrativo desconcentrado (art. 15-A-IV, de la LFPA). 19. Derecho a comparecer frente a la autoridad sólo cuando así esté previsto en la ley previa citación en la que se hará constar expresamente el lugar, fecha, hora y objeto de la comparecencia, así como los efectos de no atenderla (art. 16-I de la LFPA). 20. Derecho a entregar o exhibir informes, documentos y otros datos durante la realización de visitas de verificación, sólo en aquellos casos previstos en ésta u otras 
leyes; (art. 16-II de la LFPA). 21. Derecho a conocer, en cualquier momento, del estado de la tramitación de los procedimientos en los que tengan interés jurídico, y a obtener copia de los documentos contenidos en ellos; (arts. 16III, 33 y 34, de la LFPA). 22. Derecho a presentar y que sean admitidas las pruebas permitidas por la ley y ofrecer alegatos, los que deberán ser tomados en cuenta por el órgano competente al dictar resolución; (art. 16-V, de la LFPA). 23. Derecho a no exhibir documentos o dar a conocer información que no sean exigidos por las normas aplicables al procedimiento, o que ya se encuentren en el expediente que se está tramitando; (art. 16-VI, de la LFPA). 24. Derecho a recibir información y orientación acerca de los requisitos jurídicos o técnicos que las disposiciones legales vigentes impongan a los proyectos, actuaciones o solicitudes que se propongan realizar; (art. 16-VII, de la LFPA). 25 . Derecho al acceso a los registros y archivos que conserven las autoridades administrativas, en los términos previstos en ésta u otras leyes; (arts. 16-VIII y 33, de la LFPA y Ley Federal de Transparencia y Acceso a la Información Pública Gubernamental). Etcétera.

\section{Conclusiones}

1. Toda actuación de la Administración Pública debe tener como finalidad a la persona humana y su dignidad, porque esa es la razón de su existencia. Esto se desprende básicamente de una correcta interpretación del artículo 1 constitucional y otros preceptos de la propia Carta Fundamental.

2. Siendo así, es claro que el ciudadano tiene el derecho de exigir una Buena Administración porque de ello depende mejorar sus condiciones de vida.

3. El Derecho fundamental a una Buena Administración tiene claras características y subgarantías que le permiten su funcionalidad en nuestro país. 


\section{REFERENCIAS}

Cantarell Gamboa, Melvin; Ética y Deontología del Servidor Público; Hobiton Ediciones; México, 2001.

FerRajoli, Luigui; et. al.; Los fundamentos de los derechos fundamentales; Madrid, Trota, 2001.

Gordillo, Agustín; Tratado de Derecho Administrativo, Tomo II. La Defensa del usuario y del administrado; Buenos Aires, F.D.A. 2014.

Martínez Morales, Rafael; Derecho Administrativo, Primer Curso; Oxford University Press; México, 2011.

Oropeza López, Alejandro; Evaluación de la función pública en México; Plaza y Valdés Editores; México, 2005. 


\title{
La jurisdicción contencioso-administrativa y el acceso a la justicia
}

\author{
Jorge Alberto Estrada Cuevas*
}

Resumen: En el presente ensayo se identifican las entidades públicas distintas del Poder Ejecutivo (poderes Judicial y Legislativo, organismos constitucionalmente autónomos y universidades públicas), exentas de control jurisdiccional por parte de Tribunal Federal de Justicia Fiscal y Administrativa respecto de actos, resoluciones o actuaciones sujetas al régimen de derecho administrativo.

Se asegura, que aun cuando la Constitución federal determina la competencia material del referido Tribunal, únicamente para resolver las controversias que se susciten entre los órganos de la Administración Pública Federal y los particulares, estos pueden, eventualmente, someter a la jurisdicción contencioso-administrativa las diferencias suscitadas por licitaciones, interpretación y cumplimiento de contratos, convenios o vías de hecho, sujetos al régimen de derecho administrativo, de aquellas entidades públicas, estableciendo que ello es posible en virtud de la tutela judicial efectiva y del derecho de acceso a la justicia.

Palabras clave: Administración Pública Federal, jurisdicción, competencia, tutela judicial efectiva, derecho de acceso a la justicia, contencioso administrativo.

\footnotetext{
* Maestro en Derecho por la Facultad de Derecho y Ciencias Sociales de la Universidad Autónoma del Estado de Morelos, candidato a Doctor en Derecho por el Centro de Investigación y Docencia en Humanidades del Estado de Morelos. Magistrado del Tribunal de Justicia Administrativa del Estado de Morelos, México.
} 
Abstract: In the present essay the different public entities of the Executive Branch (judicial and legislative powers, constitutionally autonomous agencies and public universities), exempt from judicial review by the Federal Court of Fiscal and Administrative Justice regarding acts, resolutions or proceedings subject to the regime of administrative law.

It ensures that even if the federal Constitution determines the material jurisdiction of that court, only to resolve disputes that arise between the organs of the Federal Public Administration and individuals, these may eventually submit to the administrative courts the disputes concerning procurement, construction and performance of contracts, agreements or assault, subject to the system of administrative law, of those public entities, establishing that this is possible under an effective remedy and the right of access to justice.

Key words: Federal Public Administration, jurisdiction, competence, effective judicial protection, right of access to justice, administrative litigation.

\section{Introducción}

La competencia material del Tribunal Federal de Justicia Fiscal y Administrativa, está circunscrita constitucionalmente a la solución de "...las controversias que se susciten entre la administración pública federal y los particulares," Además tiene competencia para “...imponer sanciones a los servidores públicos por responsabilidad administrativa que determine la ley". ${ }^{1}$

En México, la Administración Pública Federal tiene su fundamento jurídico en el artículo 90 constitucional, el cual establece que “... será centralizada y paraestatal conforme a la Ley Orgánica que expida el Congreso.”

Conforme al texto de la ley reglamentaria, para el despacho de los asuntos

\footnotetext{
${ }^{1}$ No nos es desconocido el DICTAMEN EN SENTIDO POSITIVO A LAS INICIATIVAS CON PROYECTO DE DECRETO, POR EL QUE SE REFORMAN, ADICIONAN Y DEROGAN DIVERSAS DISPOSICIONES DE LA CONSTITUCIÓN POLÍTICA DE LOS ESTADOS UNIDOS MEXICANOS, EN MATERIA DEL SISTEMA NACIONAL ANTICORRUPCIÓN, que determina el cambio de denominación del Tribunal Federal de Justicia Fiscal y Administrativa por la de Tribunal Federal de Justicia Administrativa con las siguientes facultades:

1. Autonomía plena para dictar sus fallos, estableciendo las normas para su organización, funcionamiento, los procedimientos y los recursos contra sus resoluciones.

2. Dirimir las controversias que se susciten entre la administración pública federal y los particulares;

3. Imponer las sanciones a los servidores públicos de los poderes federales y de los órganos constitucionalmente autónomos por las responsabilidades administrativas graves en los términos que disponga la ley, a los servidores públicos locales por las irregularidades cometidas en el manejo o aplicación de los recursos de recursos federales, y a los particulares que incurran en actos de corrupción en los términos que determinen las leyes, y

4. Determinar las responsabilidades resarcitorias y las indemnizaciones y sanciones pecuniarias que deriven de los daños y perjuicios que afecten a la Hacienda Pública Federal o al patrimonio de los entes públicos federales. (Reformas al artículo 73 fracción XXIX-H)
} 
del orden administrativo, el Ejecutivo de la Unión, se apoyará de las entidades y dependencias que integran la administración pública.

Narciso Sánchez Gómez dice que la Administración Pública es "la función consistente en asegurar la aplicación cotidiana de las leyes y la marcha diaria de los servicios públicos, reunidos bajo la dirección del gobierno y para beneficio del pueblo."2 Miguel Acosta Romero refiere que "es la parte de los órganos del Estado que depende directa o indirectamente, del Poder Ejecutivo, tiene a su cargo toda la actividad estatal que no desarrollan los otros poderes (Legislativo y Judicial), su acción es continua y permanente, siempre persigue el interés público, adopta una forma de organización jerarquizada y cuenta con: a) elementos personales, b) elementos patrimoniales; c) estructura jurídica y d) procedimientos técnicos." 3

Luego, el Tribunal Federal de Justicia Fiscal y Administrativa, se constituye, en principio, como el órgano jurisdiccional revisor de los actos administrativos de los diversos órganos o dependencias de la Administración Pública Federal, que eventualmente afecten la esfera jurídica de los particulares.

No obstante que el acto administrativo aparece como presupuesto procesal para el acceso a la jurisdicción contencioso-administrativa, es claro que el Tribunal tiene competencia para conocer de todas las controversias que se susciten entre la administración pública y los particulares. ${ }^{4}$

Es decir, por una parte, el Tribunal tiene competencia para conocer de todas las controversias administrativas, mientras que por otra, dicha competencia está limitada a los actos, resoluciones o actuaciones administrativos de las autoridades formal y materialmente administrativas, provenientes de órganos o dependencias de la Administración Pública Federal; excluyendo de

${ }^{2}$ Primer Curso de Derecho Administrativo, Porrúa, México, 2003, pág. 74

3 Teoría General del Derecho Administrativo. Porrúa, México, 1995, pág. 143

${ }^{4}$ Para acceder a la jurisdicción contencioso-administrativa, considero, se requiere de alguno de estos tres supuestos:

a) Un acto legitimador de la actuación administrativa. En este caso se supone la existencia de un acto o resolución administrativos que legitimen la actuación administrativa para afectar, válidamente, la esfera jurídica de un particular; y éste en desacuerdo con dicho acto o resolución administrativos provoca la actuación jurisdiccional en defensa de sus derechos.

b) Una decisión previa de la autoridad administrativa. En este supuesto el administrado es quien pretende obtener una prestación por parte de un órgano de la administración pública y ésta omite pronunciarse sobre la petición instada o resuelve desfavorablemente, lo que habilita la vía contencioso-administrativa.

c) Una actuación de un órgano o dependencia de la Administración Pública que sin ser necesariamente un acto administrativo afecta una situación jurídica. Deriva del supuesto constitucional que determina la competencia del Tribunal para conocer de las controversias que se susciten entre la administración pública federal y los particulares; esto es, la competencia del órgano jurisdiccional no está limitada únicamente a la revisión de la regularidad de los actos y resoluciones administrativos. 
dicha competencia los actos, resoluciones o actuaciones materialmente administrativos atribuibles a otros entes públicos no pertenecientes a la estructura administrativa del Poder Ejecutivo.

Me explico:

Partiendo del texto de la fracción XXIX-H del artículo 73 de la Constitución federal, quedan fuera de la competencia del Tribunal, los actos, resoluciones o actuaciones materialmente administrativos ejecutados, por los organismos constitucionalmente autónomos, los poderes legislativo y judicial, o las universidades públicas, excepto cuando estos actos o resoluciones provengan de la aplicación de sanciones por responsabilidades administrativas de los servidores públicos o responsabilidad patrimonial del Estado.

El artículo 3 de la Ley Federal de Responsabilidades Administrativas de los Servidores Públicos faculta a las Cámaras de Senadores y Diputados, a la Suprema Corte de Justicia de la Nación, al Consejo de la Judicatura Federal, a la Secretaria de la Función Pública, a los tribunales del trabajo y agrario, al Instituto Nacional Electoral, a la Auditoria Superior de la Federación, a la Comisión Nacional de los Derechos Humanos, al Banco de México, al Instituto Federal de Telecomunicaciones, a la Comisión Federal de Competencia Económica, y demás órganos jurisdiccionales e instituciones que determinen las leyes, incluyendo al Tribunal Federal de Justicia Fiscal y Administrativa, a su aplicación.

Por otra parte, por disposición de su artículo 2, la Ley Federal de Responsabilidad Patrimonial del Estado, le es aplicable a los entes públicos federales: Poderes Ejecutivo, Legislativo y Judicial; organismos constitucionales autónomos, Procuraduría General hoy Fiscalía, Tribunales federales administrativos "y cualquier otro ente público de carácter federal.", en tanto que el artículo 24 da competencia al Tribunal para impugnar las resoluciones que nieguen el pago de una indemnización o el monto no satisfaga al interesado.

Es así, que si alguno de los órganos de control interno (contralorías o Consejo de la Judicatura por ejemplo) de las entidades públicas enunciadas en líneas anteriores aplican dicha ley para sancionar a algún servidor público federal por faltas administrativas cometidas en el desempeño de su encargo, ello habilita la jurisdicción contencioso-administrativa.

Por otra parte, el artículo 14 de la Ley Orgánica del Tribunal Federal de Justicia Fiscal y Administrativa establece los supuestos para que opere la competencia material de este órgano jurisdiccional.

De dicho artículo se desprende una cláusula más amplia de la competencia jurisdiccional del Tribunal respecto de su fundamento constitucional. En principio establece la competencia in genere, para dirimir las controversias 
que se susciten entre la administración pública federal y los particulares; luego establece competencias específicas para conocer de impugnaciones contra resoluciones emitidas por la Auditoria Superior de la Federación (fracción $\mathrm{XV}$ ), caso en el que no se circunscribe la competencia material del Tribunal, a la aplicación de la ley de responsabilidades de los servidores públicos; en seguida existen otros dos supuestos que dan competencia al Tribunal: cuando se impongan multas por infracciones a las leyes federales (fracción III), caso en el que el legislador no aclara si únicamente se refiere a multas impuestas por autoridades formal y materialmente administrativas o a cualquier clase de autoridad con independencia de que pertenezcan o no a la estructura administrativa del Poder Ejecutivo; y cuando la competencia derive de alguna ley diversa (fracción XVI), piénsese, por ejemplo, en la Ley Federal de Responsabilidad Patrimonial del Estado (Art.24).

En este orden de ideas, es fácil advertir que el legislador ordinario viene ampliando la competencia del Tribunal no sólo para conocer de actos, resoluciones o actuaciones de órganos o dependencias de la Administración Pública Federal, sino también para conocer de actos materialmente administrativos atribuibles a entidades públicas, cuyas potestades constitucionales y legales quedan fuera de la órbita del Poder Ejecutivo.

Sobre la base de lo hasta aquí dicho, considero que no existe ningún impedimento legal para que el Tribunal extienda su competencia para conocer de las controversias que se susciten por cualquier acto, resoluciones o actuaciones de naturaleza administrativa, realizados o ejecutados por entidades públicas que no formen parte integrante de la Administración Pública Federal, centralizada o descentralizada.

\section{Tutela judicial efectiva}

La tutela judicial efectiva es un derecho fundamental inmerso en el texto del artículo 17 de la Constitución federal. Dicho precepto proscribe la vindicta privada y establece que "Ninguna persona podrá hacerse justicia por si misma ni ejercer violencia para reclamar su derecho."

Establece también que "Toda persona tiene derecho a que se le administre justicia por tribunales que estarán expeditos para impartirla en los plazos y términos que fijen las leyes..."

La Primera Sala de la Suprema Corte de Justicia de la Nación ha definido a la tutela judicial efectiva como "el derecho público subjetivo que toda persona tiene, dentro de los plazos y términos que fijen las leyes, para acceder de manera expedita a tribunales independientes e imparciales, a plantear una 
pretensión o a defenderse de ella, con el fin de que a través de un proceso en el que se respeten ciertas formalidades, se decida sobre la pretensión o la defensa y, en su caso, se ejecute esa decisión." 5

Ha dicho también que "este derecho comprende tres etapas, a las que corresponden tres derechos: (i) una previa al juicio, a la que le corresponde el derecho de accesos a la jurisdicción, que parte del derecho de acción como una especie del de petición dirigido a las autoridades jurisdiccionales y que motiva un pronunciamiento por su parte; (ii) una judicial, que va desde el inicio del procedimiento hasta la última actuación y a la que corresponden las garantías del debido proceso; y, (iii) una posterior al juicio, identificada con la eficacia de las resoluciones emitidas."6

Así, queda claro, que en atención a este derecho fundamental, no deben existir zonas exentas del control jurisdiccional ordinario. El amparo, es el instrumento jurídico para garantizar la tutela judicial efectiva, no es el medio idóneo para resolver las controversias entre sujetos de derecho administrativo y los particulares. No es a través del juicio de amparo como deben resolverse las controversias que se susciten por actos materialmente administrativos de entidades públicas constitucionales autónomas, poderes Legislativo y Judicial o Universidades Públicas. Esa jurisdicción, considero, le corresponde al Tribunal Federal de Justicia Fiscal y Administrativa por ser el tribunal ad hoc.

\section{Presupuestos procesales para el acceso a la jurisdicción contencio- so-administrativa}

Para que el litigio en la jurisdicción contencioso-administrativa sea posible, es necesario que se actualice alguno de los siguientes presupuestos: a) Un acto legitimador de la actuación administrativa, el cual supone la existencia de un acto o resolución administrativos que legitiman al órgano o dependencia de la administración pública a obrar en el sentido que lo hace, y que puede afectar gravemente los derechos de los particulares; b) Una decisión previa de la autoridad administrativa provocada por el particular, lo cual supone una resolución desfavorable a las pretensiones deducidas o el silencio administrativo, y c) Una actuación de la autoridad administrativa que sin ser un acto o resolución administrativos, afectan gravemente la esfera jurídica de los particulares.

5 Tesis 1 a/J. 42/2007, publicada en el Semanario Judicial de la Federación y su Gaceta, Tomo XXV, Abril de 2007, Novena Época, pág. 124 de rubro: GARANTÍAA LA TUTELA JURISDICCIONAL PREVISTA EN EL ARTICULO 17 DE LA CONSTITUCIÓN POLÍTICA DE LOS ESTADOS UNIDOS MEXICANOS. SUS ALCANCES.

${ }^{6}$ Tesis $1^{\text {a }}$. LXXIV/20013, publicada en el Semanario Judicial de la Federación y su Gaceta, Libro XVIII, Marzo de 2013, Tomo 1, Décima Época, pág. 882 de Rubro: DERECHO DE ACCESO A LA JUSTICIA. SUS ETAPAS. 
Dichos presupuestos procesales que condicionan el pronunciamiento de una sentencia de fondo en la jurisdicción contenciosa, están determinados a superar las causales de improcedencia enumeradas por el artículo 8 de la Ley Federal de Procedimiento Contencioso Administrativo.

No me referiré a todas y cada una de las causales de improcedencia que impiden el pronunciamiento de una resolución de fondo en cuestiones efectivamente planteadas ante el órgano jurisdiccional. Solamente me haré cargo de la relativa a la falta de competencia del Tribunal prevista en la fracción II del citado numeral.

Como sabemos, jurisdicción y competencia son conceptos jurídicos distintos. Por jurisdicción comprendemos a la potestad del Estado para administrar justicia; específicamente la potestad de los tribunales judiciales para decidir el derecho.

En su Diccionario de Derecho Procesal Civil, Eduardo Pallares refiere que "Etimológicamente la palabra jurisdicción significa decir o declarar el derecho. Desde el punto de visa más general, la jurisdicción hace referencia al poder del Estado de impartir justicia por medio de los tribunales o de otros órganos..."

En tanto, la competencia "es la porción de la jurisdicción que se atribuye a los tribunales que pertenecen al mismo orden jurisdiccional." 8

La competencia se determina por razón de territorio, grado, materia y cuantía. Por territorio respecto de una demarcación o circunscripción territorial dentro de la cual determinados tribunales ejercen su jurisdicción; por grado respecto de tribunales de primera o segunda instancia; por materia atendiendo a la especialización en las ramas del derecho: civil, penal, mercantil, familiar, administrativo; y por cuantía dependiendo del valor o monto del negocio.

Así tenemos que el Tribunal Federal de Justicia Fiscal y Administrativa es un órgano del Estado con facultades para decidir y declarar el derecho mediante sentencias de fondo que resuelvan las cuestiones efectivamente planteadas respecto de controversias de naturaleza administrativa.

La competencia material del tribunal, es pues, la administrativa derivada del régimen de derecho administrativo de los órganos o dependencias del Poder Ejecutivo, según podemos advertir de la interpretación gramatical del precepto constitucional que lo instituye.

En efecto, de acuerdo a la fracción XXIX-H del artículo 73 constitucional, el Tribunal Federal de Justicia Fiscal y Administrativa es el órgano jurisdiccional encargado de "dirimir las controversias que se susciten entre la administración pública federal y los particulares."

7 Pallares, Eduardo. Diccionario de Derecho Procesal Civil, Porrúa, México, 1990, pág. 510

8 Ibídem, pág. 162 
Podemos identificar ahora, que existen entidades públicas que quedan exentas del control jurisdiccional, cuando la competencia del Tribunal se circunscribe constitucionalmente a los actos y actuaciones de la administración pública federal. No obstante que en líneas anteriores hemos dicho que el legislador ordinario ha venido ampliando la competencia que constitucionalmente corresponde al Tribunal, persisten parcelas exentas de tutela.

Así tenemos que no podrían ser objeto de tutela ante la jurisdicción contencioso administrativa los actos, resoluciones o actuaciones administrativos de organismos constitucionalmente autónomos, de los poderes judicial y legislativo o de las universidades públicas diversos a las sanciones impuestas por responsabilidad administrativa o por responsabilidad patrimonial del Estado.

Fuera de dichos supuestos, se actualiza la causal de improcedencia del juicio contencioso administrativo, sobre la base jurídica de que los actos, resoluciones o actuaciones administrativas provienen de entidades públicas diversas al Poder Ejecutivo.

Licitaciones públicas, interpretación y cumplimiento de contratos administrativos, convenios y vías de hecho sujetos al régimen de derecho administrativo quedan exentas de tutela judicial si provienen de organismos constitucionalmente autónomos, poderes judicial y legislativo o universidades públicas. En la causal de improcedencia prevista en la fracción II del artículo 8 de la ley relativa, se encuentra un obstáculo al derecho de acceso a la justicia; obstáculo que puede ser franqueado con fundamento en la tutela judicial efectiva y principio in dubio pro actione o favor actionis (estar a lo que más favorezca el derecho de acción).

El artículo 17 de la Constitución federal al que nos hemos referido anteriormente y el 25 de la Convención Americana, sustentan el derecho fundamental a la tutela judicial efectiva. En esta guisa, habrá de tomarse en cuenta que la fracción II del artículo 8 de la Ley Federal de Procedimiento Contencioso Administrativo constituye una barrera de acceso a la jurisdicción; y, conforme a la nueva técnica jurídica, cabe la posibilidad de su desaplicación mediante el control difuso.

Ya apunté anteriormente que el juicio de amparo es el instrumento jurídico garante de los derechos humanos y fundamentales; no es el medio idóneo para la solución de controversias; para ello están las instancias procesales ordinarias y una de estas instancias es precisamente, la jurisdicción contencioso administrativa para dirimir toda clase de controversias derivadas de la aplicación del derecho administrativo.

El derecho administrativo es la base del funcionamiento de todos los órganos estatales; solo a través de él es posible la función legislativa o judicial. 
Existe un régimen administrativo para estas entidades públicas; igualmente ocurre con los organismos constitucionalmente autónomos y con las universidades públicas. Es cierto que existe un régimen de derecho administrativo para la Administración Pública Federal, pero también es cierto que existe ese régimen para otras entidades públicas que se constituyen fuera de la órbita del Poder Ejecutivo.

La Comisión interamericana de Derechos Humanos ha dicho que “...la tutela judicial efectiva puede traducirse en la garantía de la libre entrada a los tribunales para la defensa de los derechos e intereses frente al poder público, aún cuando la legalidad ordinaria no haya reconocido un recurso o acción concreto. Este principio implica lógicamente un conjunto de garantías elementales en la tramitación de los procesos judiciales." También ha dicho que "...la incertidumbre o falta de claridad en la consagración de estos requisitos de admisibilidad constituya una violación a dicho derecho fundamental", y que "Las garantías a la tutela judicial efectiva y al debido proceso imponen una interpretación más justa y beneficiosa en el análisis de los requisitos de admisión a la justicia, al punto que por el principio pro actione, hay que extremar las posibilidades de interpretación en el sentido más favorable al acceso a la jurisdicción."

En síntesis que la tutela judicial efectiva “...impide que el acceso a la justicia se convierta en un desagradable juego de confusiones en detrimento de los particulares"9

De esta manera, conflictos derivados de licitaciones, adjudicación de contratos de obra pública, interpretación y cumplimiento de dichos contratos, convenios y vías de hecho ejecutados por autoridades judiciales, legislativas, organismos constitucionalmente autónomos o universidades en ejercicio de facultades materialmente administrativas, pueden ser del conocimiento del tribunal administrativo, y no por otra clase de tribunales, atendiendo a su especialidad.

\section{La jurisdicción contencioso administrativa en las entidades federativas}

El fundamento constitucional de la jurisdicción contencioso-administrativa en las entidades federativas se encuentra en el artículo 116 fracción V. Dicho numeral establece, replicando la redacción del artículo 73 fracción XXIX-H determina, que "Las constituciones y Leyes de los Estados podrán instituir Tribunales de lo Contencioso Administrativo dotados de plena autonomía para dictar sus fallos, que tengan a su cargo dirimir las controversias que se susciten entre la Administración Pública Estatal y los particulares..."

${ }_{9}$ Informe 105/99, caso 10.194 Palacios, Narciso-Argentina, 29 de septiembre de 1999. 
Como vemos, en una interpretación gramática, la competencia de los tribunales administrativos de las entidades federativas se circunscribe también a los actos, resoluciones o actuaciones administrativas de dependencias incorporadas a la estructura de la Administración Pública del Estado.

Es importante resaltar que dicha competencia no es sólo revisora de la regularidad de los actos administrativos, sino para resolver toda clase de controversias entre los sujetos del derecho de la materia.

Es así que los tribunales locales tienen competencia para resolver controversias sobre licitaciones públicas, interpretación y cumplimiento de contratos administrativos, convenios y vías de hecho de carácter administrativo de entidades públicas distintas del Poder Ejecutivo local y los particulares.

En el Estado de Morelos son actos sujetos al régimen de derecho administrativo de los poderes Judicial y Legislativo, Consejo de la Judicatura, Comisión Estatal de Derechos Humanos, Instituto Morelense de Información Pública y Estadística y Universidad Autónoma.

De igual manera, la causal de improcedencia que se inscribe en el supuesto de la falta de competencia del tribunal para conocer de actos que no formen parte de la Administración Pública, contenida en las legislaciones de la materia, constituye un obstáculo al derecho de acceso a la justicia. La vigencia de dicha causal de improcedencia, permite la existencia de parcelas de poder, en el ámbito del derecho administrativo, exentas del control jurisdiccional.

\section{Conclusiones}

La competencia material del Tribunal Federal de Justicia Fiscal y Administrativa, está circunscrita constitucionalmente, a la resolución de controversias suscitadas entre la administración pública federal y los particulares.

El legislador ordinario ha venido ampliando la competencia material del referido tribunal para conocer de conflictos derivados de la aplicación de sanciones a los servidores públicos y de responsabilidad patrimonial del Estado, inscritos en el régimen de derecho administrativo de entidades públicas distintas al Poder Ejecutivo.

En virtud de la tutela judicial efectiva, al derecho de acceso a la justicia e indubio pro actione, es posible enjuiciar actos materialmente administrativos por licitaciones públicas, interpretación y cumplimiento de contratos, convenios y vías de hecho de los poderes Judicial y Legislativo, organismos constitucionalmente autónomos y universidades públicas.

El juicio de amparo no es el medio idóneo para resolver las controversias entre sujetos de derecho administrativo y los particulares; es el instrumento 
jurídico garante de la tutela judicial efectiva y del derecho de acceso a la justicia.

Mediante el control difuso que corresponde a los jueces conforme a la nueva técnica jurídica, se deben desaplicar las disposiciones legales que determinen la improcedencia de la vía contenciosa administrativa, cuando lo que se impugne sean actos, resoluciones o actuaciones administrativos de entidades públicas distintas del Poder Ejecutivo. 


\section{Bibliográficas}

\section{REFERENCIAS}

Sánchez Gómez, Narciso. Primer Curso de Derecho Administrativo, Porrúa, México, 2003.

Acosta Romero Miguel. Teoría General del Derecho Administrativo, Porrúa, México, 1995.

Pallares, Eduardo. Diccionario de Derecho Procesal Civil, Porrúa, México, 1990.

\section{Electrónicas:}

Tesis 1a/J. 42/2007, publicada en el Semanario Judicial de la Federación y su Gaceta, Tomo XXV, Abril de 2007, Novena Época, pág. 124 de rubro: GARANTÍA A LA TUTELA JURISDICCIONAL PREVISTA EN EL ARTICULO 17 DE LA CONSTITUCIÓN POLÍTICA DE LOS ESTADOS UNIDOS MEXICANOS. SUS ALCANCES.

Tesis $1^{\text {a }}$. LXXIV/20013, publicada en el Semanario Judicial de la Federación y su Gaceta, Libro XVIII, Marzo de 2013, Tomo 1, Décima Época, pág. 882 de Rubro: DERECHO DE ACCESO A LA JUSTICIA. SUS ETAPAS.

Visibles en https://www.scjn.gob.mx/Paginas/Inicio.aspx (14 mayo 2015) Comisión Interamericana de Derechos Humanos. Informe 105/99, caso 10.194 Palacios, Narciso-Argentina, 29 de septiembre de 1999, visible en: http://www.cidh.org/annualrep/99span/De\%20Fondo/Argentina10.194.htm (14 mayo de 2015) 


\section{Los retos de la argumentación en los convenios para evitar la doble imposición en la globalización Juan de Dios González Ibarra* Bárbara Edith Orihuela Rosas**}

Resumen: La metametodología hermenéutica aplicable a los convenios para evitar la doble imposición, consiste en partir desde la complejidad contemplando la intertextualidad para lograr la más acertada interpretación de ellos, construyendo espacios y tiempos en los cuales se funde lo nacional y lo internacional en una multidimensionalidad rica de matices, saberes y metáforas. La metáfora que se basa en descubrir haideggerianamente semejanzas y diferencias, en el campo de los convenios para evitar la doble tributación toma como primer analogado al cumplimiento fiscal, así argumentamos que ya cumplida la exigencia fiscal en un país no procede repetirla conforme lo convenido entre países.

Palabras clave: Doble imposición, matametodología hermenéutica, complejidad, argumentación, multidimensionalidad.

Abstract: The Metamethodology hermeneutics applicable to agreements to avoid double taxation, consists in starting from the complexity contemplating intertextuality to achieve the most accurate interpretation of them, building

* Doctor en Ciencias Políticas por la Universidad Nacional Autónoma de México. Profesor investigador de tiempo completo en la Facultad de Derecho y Ciencias Sociales de la Universidad Autónoma del Estado de Morelos. Miembro del Sistema Nacional de Investigadores, nivel II. Autor en diversos artículos, revistas y libros.

** Maestra en Derecho por la Universidad Autónoma del Estado de Morelos y Doctoranda en Derecho por la misma universidad. 
spaces and times in which the national and the international melts into a rich multidimensionality of nuances, knowledge and metaphors. The metaphor is based on discovering using Haidegger's philosophy similarities and differences in the field of agreements to avoid double taxation taken as first-analogate to tax compliance, we argue that fulfilled the tax demand in a country is not proceed to repeat the tax demand in the other country conforming with the agreement to avoid double taxation.

Key words: Double taxation, metamethodology hermeneutics, complexity argumentation, multidimensionality.

\section{Introducción}

En la globalización, definida como el dominio mundial del capital financiero, con el neologismo de bancocracia incluido, ya no basta la sola interpretación de los convenios de doble impocición, pues quien invoca la exención del pago de una duplicación de la imposición fiscal debe argumentar que ella va en contra de los tratados firmados en este campo, requieren pues de una sólida racionalización que cree la convicción en las autoridades hacendarias de los países signatarios que asiste la razón a quien se encuentra en el caso particular dentro del seno del derecho internacional tributario, es más, podemos, afirmar que nos encontramos hoy en el campo de un espacio metajurídico complejo que nos obliga a salirnos de los derechos nacionales e internacionales, creándose un ámbito que va más allá de lo internacional que identificamos con Edgar Morin como complejo o multidimensional, con lo que afirmamos que los tratados responden a otra lógica que implica una metametodología para su argumentación y aplicación.

\section{El espacio metajurídico complejo de la doble tributación internacional}

Las amenazas más graves que enfrentan los contribuyentes en materia de doble imposición, están ligadas al progreso ciego e incontrolado de la firma de los convenios para evitar la doble tributación que surge de un modo mutilante de la organización del conocimiento, incapaz de reconocer y de aprehender la complejidad de lo que realmente conlleva cada tratado en lo real. Se trata pues de evitar la visión unidimensional, parcial, siendo necesario, ante todo, tomar conciencia de la naturaleza y de las consecuencias de los paradigmas que mutilan el conocimiento de los convenios de doble imposición y desfiguran lo real. ${ }^{1}$

1 En este punto, es menester que el conocimiento se organice desde dos puntos de vista en geocéntrica, donde los geocentristas rechazaban los datos inexplicables; y desde un punto de 
En la aplicación de los convenios para evitar la doble imposición nos guiamos por una inteligencia ciega, que destruye los conjuntos y las totalidades, aísla todos sus objetos de sus ambientes. Las realidades clave son desintegradas. Las disciplinas de las ciencias humanas no necesitan así falazmente más de la noción de lo complejo y sus dimensiones estructurales, funcionales, multi y transdisciplinaria. La metodología dominante produce oscurantismo porque no hay más asociación entre los elementos diversos del conocer y del saber. Hablamos de una mutación sin precedentes en el conocimiento de los convenios para evitar la doble imposición, donde la nueva, masiva y prodigiosa ignorancia es tratada por ausencia.

Así, la incapacidad para concebir el espacio metajurídico y la complejidad en los convenios para evitar la doble imposición, pretenden evadir la compleja realidad socioeconómica global, en su micro-dimensión (el ser individual como contribuyente ) y en su macro-dimensión (el contribuyente como parte de una nación y el conjunto de los convenios para evitar la doble imposición signados), ha conducido a injusticias y nos condujo a la situación actual en donde las grandes empresas fácilmente puede ser beneficiadas del sistema de convenios, mientras que al contribuyente particular le es difícil dominar este campo, así caemos en la contradicción en donde desde la óptica empresarial se ve a la política tributaria-administrativa como algo simplificante, cuando ésta requiere del conocimiento complejo, pues debe analizar lo incierto, lo aleatorio, el juego múltiple de las interacciones y las retroacciones de convenios y naciones.

En este orden de ideas analizaremos ahora por preguntarnos: ¿Qué es la complejidad?, y ¿qué es la complejidad en el ámbito de los convenios para evitar la doble imposición? Diremos que lo es metafóricamente el tejido de eventos, acciones, interacciones, retroacciones, determinaciones, azares, que constituyen nuestro mundo tributario. La complejidad ante la ignorancia se presenta con los rasgos inquietantes de lo enredado, de lo inextricable, del desorden, la ambigüedad, la incertidumbre. Siendo la virtud del pensamiento complejo el poder afrontar lo entramado, es decir el juego infinito de inter-retroacciones, la intertextualidad de los fenómenos entre sí, apoyado en la lógica difusa y teoría de sistemas borrosos, la bruma, la incertidumbre, las fronteras que se funden entre sí, la contradicción y su dialéctica.

Es aquí donde el paradigma de disyunción se sustituye por un "paradigma de distinción/conjunción que permite distinguir sin desarticular, asociar sin identificar o reducir. Este paradigma conlleva al principio dialógico y translógico, que integraría la lógica clásica teniendo en cuenta sus límites de facto

vista heliocéntrico, donde sus visionarios se fundan en los datos inexplicables. 
(problemas de contradicciones) y de jure (límites del formalismo). Llevaría en sí el principio de la unitas multiplex, que pretende escapar a la unidad dialéctica de lo alto y por lo bajo, ${ }^{2}$ de lo negativo y positivo

La patología de la razón actual es racionalización que pretende encarcelar a la comprensión de la realidad en un sistema de ideas lineales, parcial y unilateral, que no distingue que una parte de lo real es irracionalizable, ni de que la racionalidad tiene por misión dialogar con lo irracionalizable. Lo que denota que aún somos ciegos a la complejidad, tal vez porque estamos en la prehistoria del desarrollo del espíritu humano con su gran capacidad de fraternidad no desarrollada. El pensamiento complejo nos permite enriquecer nuestro conocimiento y, más aún, el saber metajurídico complejo de los convenios para evitar la doble imposición.

En la ciencia la complejidad había surgido sin decir su nombre en el siglo $\mathrm{XX}$, con la micro-física y la macro-física. Pero estas dos complejidades micro y macrofísicas eran rechazadas a la periferia de nuestro universo, si bien se ocupaban de fundamentos de nuestra physis y de caracteres intrínsecos de nuestro cosmos. Entre ambas, el dominio físico, biológico, humano, la ciencia reducía la complejidad fenoménica a un orden simple y a unidades elementales. ${ }^{3}$ Lo mismo ocurre actualmente con la reducción de los convenios para evitar la doble imposición a lo nacional y lo internacional, se reduce a una monovisión fenoménica y simple, a un simple discurso jurídico pero no a una argumentación metajurídica compleja que nos lleva al ámbito multidimensional de los convenios para evitar la doble imposición.

Pero ¿qué es la complejidad? a primera vista, es un fenómeno cuantitativo, pero la complejidad no comprende solamente cantidades y unidades e interacciones que desafían nuestras posibilidades de cálculo, la complejidad siempre está relacionada con el azar. De esta manera, la complejidad coincide con un aspecto de incertidumbre. La complejidad está así ligada a una mezcla de orden y de desorden, donde el orden reina a nivel de las grandes empresas, y el desorden domina en el ámbito de los pequeños contribuyentes como personas físicas. Señalemos también que se le ha atribuido la concepción de una complejidad particular a la que opondría la global. La idea misma de complejidad lleva en sí la imposibilidad de unificar, la imposibilidad del logro, una parte de incertidumbre, una parte de indecibilidad. Esto no quiere decir que la complejidad de la que se habla se confunde con el relativismo absoluto, el escepticismo estilo Feyerabend.

${ }^{2}$ Morin, Edgar, Introducción al pensamiento complejo, Gedisa, Barcelona, 1991, p. 30.

${ }^{3}$ Morin, Edgar, op. cit., p.58 
La fuente más profunda de malentendidos concierne en el modo de compartimentar y desestructurar sus propios pensamientos, es decir, en la organización de los elementos del conocimiento. Esto plantea el problema del paradigma. Es necesario descifrar un camino por el cual sería posible que hubiera una reorganización y un desarrollo del conocimiento, ya que no conforme al deterioro ambiental, la desigualdad mundial, las guerras interminables con sus hambrunas, podemos sostener que nos encontramos en la prehistoria del espíritu humano.

Dando respuesta a la segunda interrogante: ¿Qué es la complejidad en el ámbito de los convenios de doble imposición?, diremos que el referirnos al espacio metajurídico complejo, implica y conlleva rebasar a lo nacional y lo internacional. La dificultad de la complejidad en el ámbito de la doble imposición no está solamente en la renovación de la concepción del objeto (es decir lo nacional o lo internacional), sino en revertir las perspectivas epistemológicas del sujeto, es decir, el observador internacional que aplica la normatividad en la globalización.

\subsection{EI sujeto y el objeto complejos en la doble imposición internacional}

La doble imposición surge después de la Primera Guerra Mundial. Al término de ésta se intensificaron las relaciones económicas transfronterizas, introduciéndose primeramente el concepto de "renta mundial", a través del cual los ciudadanos o residentes de un país quedaban sujetos a gravamen por todos sus ingresos, sin importar el lugar donde lo hubiesen obtenido, aún si se tratare de otros países, surgiendo aquí la doble imposición internacional.

Al existir la posibilidad de la existencia de una doble imposición internacional, necesariamente se ven impactadas las relaciones internacionales, apareciendo aquí el derecho tributario internacional como disciplina tendiente a dar soluciones equitativas para evitar la doble imposición. ${ }^{4}$ Sáinz de Bujanda define al derecho tributario internacional como una rama del derecho internacional, cualificada por la naturaleza tributaria de las relaciones entre Estados que en ese derecho se regulan. ${ }^{5}$ Cabe destacar, y no es óbice, que el derecho tributario internacional se compone de preceptos de derecho internacional, de derecho internacional general, y sobre todo de derecho internacional contractual, así como de normas de derecho interno y de la comunidad internacional. ${ }^{6}$

\footnotetext{
${ }^{4}$ Se da cuando una persona física o moral realiza actividades en dos o más países y se encuentra con que debe pagar impuestos en ambas jurisdicciones

${ }^{5}$ Sáinz de Bujanda, Fernando, "La interpretación en derecho español, de los tratados internacionales para evitar la doble imposición “, Revista de Derecho Financiero y Hacienda pública, núm.38, Madrid, junio de 1960, p. 286.

${ }^{6}$ Hallivis, Manuel, Interpretación de Tratados Internacionales Tributarios, Porrúa, México, 2011, p. 140.
} 
Pasemos ahora al estudio del sujeto. En general el sujeto emerge al mismo tiempo que el mundo, sobre todo a parir de la auto-organización, cuando autonomía, individualidad, complejidad, incertidumbre, ambigüedad, se vuelven caracteres propios del ser humano. El sujeto emerge también en sus características existenciales, lleva en sí su individualidad irreductible, su lenguaje, su suficiencia ${ }^{7}$ y su insuficiencia ${ }^{8}$. Contiene en sí la brecha, la fragmentación, la realización, la pérdida, la muerte, el más allá.

El sujeto o los sujetos en los convenios para evitar la doble imposición no deben limitarse a un análisis óntico. Donde simplemente hablamos de la identidad del sujeto o sujetos gravados, como un elemento para que ésta se dé. El sujeto debe verse de manera compleja como una parte inseparable del objeto principal de estudio de los convenios 'para evitar la doble imposición. El sujeto y el objeto aparecen así como las dos emergencias últimas, inseparables de la relación auto-organizador/ecosistema. Aparece la gran paradoja: sujeto y objeto son disociables. En el ámbito de los convenios para evitar la doble imposición los sujetos y el objeto impositivo forman parte de un sistema armonizador que se remonta de complejidad en complejidad, donde se llega finalmente a un sujeto o sujetos reflexivos.

Una nueva concepción emerge tanto de la relación compleja del sujeto y del objeto, como del carácter insuficiente e incompleto de una y otra noción. El sujeto debe permanecer abierto, desprovisto de un principio de decidibilidad en sí mismo; el objeto fiscal mismo debe permanecer abierto, por una parte sobre el sujeto, por otra parte sobre su ambiente, el cual a su vez, se abre necesariamente y continúa abriéndose más allá de los límites de nuestra realidad nacional y su entendimiento. ${ }^{9}$

\section{Rebasando lo nacional y lo internacional para llegar al ámbito multi- dimensional}

Primeramente debemos visualizar los campos ontológicos de lo nacional y lo internacional en materia de doble imposición, para después dar el salto a lo epistémico y estar en sintonía con la multidimensionalidad en la que habitan y se mueven los multicitados convenios. Nuestra Constitución Política hace referencia a varias cuestiones que incluyen el derecho doméstico y el derecho internacional. El primer punto a tratar es la supremacía constitucional que

\footnotetext{
${ }^{7}$ En tanto ser recursivo que se envuelve siempre sobre sí mismo.

${ }^{8}$ En tanto ser abierto indecidible en sí mismo.

${ }^{9}$ El error ontológico era el de dejar encerrados, es decir, petrificados, los conceptos de base de la ciencia, por el contrario es necesario abrir la posibilidad de un metaconocimiento a la vez más rico y menos reducido.
} 
en nuestro derecho interno es el precepto fundamental del orden jerárquico normativo mexicano, que se encuentra regulado por el artículo 133 Constitucional. ${ }^{10}$ Así el principio de supremacía advierte la subordinación de las leyes del congreso y de los tratados celebrados por el presidente con aprobación del senado a la Constitución Federal. ${ }^{11}$ Entonces hablamos de una doble regulación, esto es, por un lado del derecho nacional y, a la vez, de los tratados internacionales que son la base del derecho internacional. Donde es evidente la colisión del derecho internacional ante el derecho nacional.

La supremacía constitucional estipulada en el multicitado artículo 133 constitucional, se ve afectada de forma positiva por el derecho internacional a través de la reforma que entró en vigor el 10 de junio de 2011. ${ }^{12}$ Dicha reforma consistió en ampliar la protección a los derechos humanos de tal manera que si un tratado internacional suscrito por nuestro país otorga una mayor protección a los Derechos humanos, deberá aplicarse el tratado. Lo que se conoce en el derecho internacional como principio pro homine.

Respecto a lo anterior, el ministro presidente Juan Silva Meza de la Suprema Corte de Justicia de la Nación, señaló en su discurso en la firma del decreto que modificó el Capítulo I de nuestra Constitución lo siguiente: “....entre la Constitución mexicana y los tratados internacionales en materia de derechos humanos que nos obligan, no hay divergencias, no hay contradicción: su finalidad es la misma. Por eso, la reforma no atenta contra la Constitución: la fortalece, la mejora..."13 De tal suerte que la reforma constitucional de 10 de junio de 2011 tuvo y tiene un alcance de gran importancia para nuestro país al poner nuevamente a nuestra Constitución a la vanguardia mundial; destacan-

10 “Artículo 133. Esta constitución, las leyes del congreso de la unión que emanen de ella y todos los tratados que estén de acuerdo con la misma, celebrados y que se celebren por el presidente de la república, con aprobación del senado, serán la ley suprema de toda la unión. Los jueces de cada estado se arreglarán a dicha constitución, leyes y tratados, a pesar de las disposiciones en contrario que pueda haber en las constituciones o leyes de los estados". El antecedente del artículo 133 se encuentra en el precepto 126 de la Constitución de 1857 que señalaba que "la Constitución, las leyes del congreso de la unión que emanen de ella y todos los tratados hechos o que se hicieren con el presidente de la República, con aprobación del congreso serán la Ley Suprema de toda la Unión. Los jueces de cada estado se arreglarán a dicha Constitución, leyes tratados, a pesar de las disposiciones en contrario que pueda haber en las Constituciones o leyes de los estados".

${ }^{11}$ Se debe destacar que con la reforma del 11 de Junio de 2011 se pone al mismo nivel la Constitución Federal y los tratados internacionales, cuestión que en párrafos que preceden se tratará a profundidad.

${ }^{12}$ Siendo interesante para el tema en desarrollo la reforma a los artículos $1^{\circ}, 15,29$ y 89-X.

${ }^{13}$ Discurso pronunciado por el Ministro Presidente de la SCJN, Silva Meza, con motivo de la firma del Decreto que modifica la denominación del capítulo I del título primero y Reforma diversos artículos de la constitución política de los Estados Unidos Mexicanos, 9 de junio de 2011, p. 2. http://www.scjn.gob.mx/Presidencia/Ministro_Presidente_Junio/12_JUNIO\%2009\%202011_ MIN\%20SILVA\%20EN\%20FIRMA\%20DECRETO\%20REFORMA\%20DERECHOS\%20HUMANOS\%20EN\%20PINOS.pdf 
do que de acuerdo con el Dictamen de la Cámara de Senadores, al artículo 1o de nuestra Carta Magna incorporó: “...el goce de los derechos humanos reconocidos en la Constitución y en todos los tratados internacionales que haya ratificado México, así como de las garantías para su protección. Incorpora la interpretación conforme a la Constitución y a los tratados internacionales en la aplicación de las normas de derechos humanos, así como el principio pro persona..." 14

Es menester acotar que el principio pro homine o pro persona, implica que el derecho debe interpretarse siempre de la forma que más favorezca a las personas, es decir, debe aplicarse la norma que más beneficie a la persona afectada sin importar la jerarquía de las leyes; o en otras palabras, si un derecho reconocido en un tratado internacional otorga mayor protección a la persona que cualquier otro ordenamiento federal o local, incluso la propia Constitución, se aplica el primero. ${ }^{15}$ Debemos señalar además que éste principio, de gran innovación para nuestro país, ya estaba consagrado en el plano del derecho internacional en los artículos 29 de la Convención Americana sobre Derechos Humanos y 5o del Pacto Internacional de Derechos Civiles y Políticos.

Como se menciona en párrafos que anteceden a la reforma constitucional del 10 de junio de 2011, cambió de forma profunda lo referente a los derechos humanos y de aplicación de los tratados internacionales, lo que afirma la postura de México como miembro activo de la comunidad internacional de naciones que en palabras de Hallivis "pugna por un derecho internacional público que se cumpla de buena fe". ${ }^{16} \mathrm{En}$ base a la nueva reforma surgen las siguientes interrogantes itienen la misma jerarquía los tratados internacionales que versan sobre derechos humanos que los tratados no relativos a derechos humanos? ¿Se encuentran al mismo nivel que la Constitución los tratados que no versen sobre derechos humanos? La verdad es que estas interrogantes de carácter ontológico deben ser rebasadas para dar lugar a la visión multidimensional de los convenios de doble imposición. Esto es, no importa la jerarquía, la pirámide de Kelsen ha quedado atrás superada por la dinámica jurídica. No hablamos ya de derecho nacional y derecho inter-

\footnotetext{
${ }^{14}$ Cámara de Senadores, Dictamen de las comisiones unidas de puntos constitucionales y de estudios legislativos, con opinión de la Comisión de Reforma del Estado, respecto del proyecto que modifica diversos artículos de la Constitución Política de los Estados Unidos Mexicanos, en materia de Derechos Humanos, 17 de febrero de 2011, p.7.

15 Tesis Aislada, 10a. Época; Tribunal Colegiado de Circuito, S.J.F. y su Gaceta; Libro VII, Abril de 2012, Tomo 2; número de registro, p. 1838. "pro homine. Si en un caso concreto no se actualiza la antinomia de dos normas que tutelan derechos humanos, este principio no es el idóneo para resolverlo... Así, cuando esa regla se manifiesta mediante la preferencia interpretativa extensiva, implica que ante diferentes interpretaciones de un dispositivo legal, debe optarse por aquella que conduzca a una mejor y más amplia protección de los derechos fundamentales".

${ }^{16}$ Hallivis, Manuel, Interpretación de Tratados Internacionales Tributarios, Porrúa, México, 2011, p. 171.
} 
nacional. La cuestión y la interrogante es: ¿Cuáles son las líneas argumentativas y la metametodológicas que deben regir y guiar lo multidimensional para evitar la doble imposición internacional? ${ }^{17}$

Es importante señalar que la reforma se queda en nivel previo a la reflexión, pone a un mismo nivel a los tratados internacionales y la Constitución misma, es decir otorga simplemente un paliativo a la aplicación de los convenios, limitándose únicamente a convenios que contemplen derechos humanos. Pero si empleamos la reflexión observaremos que el texto constitucional no hace referencia sólo a los tratados en materia de derechos humanos, sino a los derechos humanos previstos en los tratados internacionales que son todos, razón por la cual algunos tratadistas prefieren el concepto de derechos fundamentales. Lo anterior significa que se contemplan no sólo los tratados cuya naturaleza y esencia sean los derechos humanos, sino también las disposiciones que contengan dichos derechos, es decir, se trata de tratados internacionales que no formen parte del grupo reconocido de derechos humanos, como los son algunos tratados celebrados por parte de la Organización Internacional del Trabajo (OIT) y de los cuales el Estado Mexicano es parte y que protege derechos humanos de los trabajadores, sin ser explícitamente tratados reconocidos como defensores de los derechos humanos.

Lo mismo ocurre con los convenios para evitar la doble imposición que a partir de la reforma de junio de $2011 \mathrm{y}$, de acuerdo con lo analizado con antelación, los tratados independientemente de la materia que traten (o convenios) si contienen consagrada la protección de un derecho humano, éste debe ser tutelado y aplicado sin importar la naturaleza del tratado. Citemos algunos ejemplos para dejar claras las ideas planteadas: "El Convenio entre los gobiernos de los Estados Unidos Mexicanos y de la República Federativa del Brasil para evitar la doble imposición y prevenir la evasión fiscal en materia de impuestos sobre la renta.", que en su artículo 24 contemplan la cláusula de "no discriminación" que en su punto primero menciona que "los nacionales de un Estado contratante no serán sometidos en el otro Estado contratante, a ningún impuesto u obligación relativa al mismo, que no se exija o que sea más gravoso que aquél a los que estén o puedan estar sometidos los nacionales de este otro Estado contratante que se encuentren en las mismas condiciones..."18

Otro ejemplo lo encontramos en el decreto promulgatorio del "Acuerdo entre los Estados Unidos Mexicanos y la República Federal de Alemania para evitar la doble imposición y la evasión fiscal en materia de impuestos sobre la renta y sobre el patrimonio", que en su artículo 24 se refiere a la cláusula

${ }^{17}$ Interrogante que será diseccionada a lo largo de las subsecuentes líneas.

${ }^{18}$ Convenio entre los gobiernos de los Estados Unidos Mexicanos y de la República Federativa del Brasil para evitar la Doble Imposición y prevenir la Evasión fiscal en materia de impuestos sobre la renta, página de la Secretaría de Hacienda y Crédito Público, ftp://ftp2.sat.gob.mx/asistencia_servicio_ftp/publicaciones/legislacion07/Brasi120070101.pdf 
de no discriminación, así establece en el artículo primero: "Los nacionales de un Estado contratante no serán sometidos en el otro Estado contratante, a ningún impuesto u obligación relativo al mismo, que no se exija o que sea más gravoso que aquéllos a los que estén o puedan estar sometidos los nacionales de este otro Estado que se encuentren en las mismas condiciones, en particular con respecto a la residencia. No obstante las disposiciones del artículo 1o, la presente disposición es también aplicable a las personas que no sean residentes de uno o de ambos Estados contratantes. Artículo segundo: "Los apátridas residentes de un Estado contratante no se someterán en ninguno de los Estados Contratantes a ningún impuesto u obligación relativa al mismo, que no se exija o que sea más gravoso que aquellos a los que estén o puedan estar sometidos los nacionales del Estado respectivo que se encuentren en las mismas condiciones..."19

Partiendo de una reflexión extensiva de los artículos de la Constitución $1^{\circ}$ y 133 Constitucional con motivo de la reforma de junio de 2011 y con los convenios antes citados, nos percatamos que los convenios contra la doble imposición suscritos por nuestro país, que contemplen dicho principio u otros principios que otorguen protección en términos de igualdad, o de equidad de los nacionales de un país u otro, son el claro ejemplo de que nos encontramos ante el objeto complejo y multidimensional de los convenios de doble imposición, y observamos también que no hablamos ya de derecho nacional e internacional, sino de la protección del sujeto y del objeto de los convenios de doble imposición a través de la reflexión, aterrizada en una correcta metaargumentación que va más allá de la simple interpretación ontológica.

\section{La metametodología de los convenios para evitar la doble imposición internacional en la globalización}

El punto articular para las investigaciones fundamentales, y el punto medular de la argumentación como medio idóneo para evitar la doble imposición internacional es un conjunto teórico-metametodológico-epistemológico, a la vez coherente y abierto. Se trata de un discurso multidimensional no totalitario, teórico pero no doctrinario, abierto a incertidumbre y a la trascendencia; no ideal-idealista, sabiendo que la cosa no será nunca totalmente encerrada en el concepto, el mundo jamás aprisionado en el discurso.

Desafortunadamente en nuestro país y a nivel internacional en materia de doble imposición a la hora de resolver los conflictos las partes se limitan a un análisis teórico-práctico, que carece de un estudio metametodológico-epis-

${ }^{19}$ Decreto Promulgatorio del Acuerdo entre los Estados Unidos Mexicanos y la República Federal de Alemania para Evitar la Doble Imposición y la Evasión Fiscal en Materia de Impuestos sobre la Renta y sobre el Patrimonio, firmado en la Ciudad de México, el 9 de julio de 2008, p.14. 
temológico, lo que condena de entrada la rica reflexión de cada asunto sin visualizar el todo, sin delimitar correctamente las líneas de respuesta a cada conflicto, las cuales sólo pueden ser intercontextualizadas por la metametodología que requieren los convenios de doble imposición, al tener como hemos expresado anteriormente un carácter multidimensional. La anterior carencia de metametodología epistémica en el ámbito nacional e internacional, la podemos ver expresada en las reglas interpretativas que dichos derechos toman como guía al momento de aplicar los convenios de doble imposición. Primero que nada se debe atender de acuerdo con la SCJN a lo establecido en los artículos 31 y 32 de la Convención de Viena sobre el Derecho de los Tratados y, en segundo término, al Modelo de Convenio de la OCDE para evitar la doble imposición. En efecto, al tenor de lo previsto en el artículo 31 de la mencionada convención para interpretar los actos jurídicos de la referida naturaleza como regla general debe, en principio, acudirse al sentido literal de las palabras utilizadas por las partes contratantes al redactar el respectivo documento final debiendo, en todo caso, adoptar la conclusión que sea lógica con el contexto propio del tratado y acorde con el objeto o fin que se tuvo con su celebración; es decir, debe acudirse a los métodos de interpretación literal, sistemática y teleológica... siendo conveniente precisar que en términos de lo dispuesto en el artículo 32 de la Convención de Viena sobre los Tratados, para realizar la interpretación teleológica y conocer los fines que se tuvieron con la celebración de un instrumento internacional no debe acudirse, en principio, a los trabajos preparatorios de éste ni a las circunstancias que rodearon su celebración, pues de éstos el intérprete únicamente puede valerse para confirmar el resultado al que se haya arribado con base en los elementos antes narrados o bien cuando la conclusión derivada de la aplicación de éstos sea ambigua, oscura o manifiestamente absurda. ${ }^{20}$ Así la SCJN hace un reconocimiento casi textual a los principios interpretativos que consigna la Convención de Viena, siendo sus principios hermenéuticos plenamente aplicables en México.

En segundo término el derecho nacional debe atender a lo establecido por la OCDE en el Modelo de Convenio para Evitar la Doble Imposición Internacional entre sus países miembros. La OCDE establece un criterio uniforme para la solución de controversias, que a su vez formuló ex profeso los comentarios como lineamientos de interpretación de las disposiciones del modelo de convenio y de los acuerdos que de éste deriven. Señala la propia Corte que constituyen el mejor instrumento para aplicar adecuadamente, y de manera uniforme, las disposiciones de los convenios tributarios que celebren los países de esa organización, en tanto que ello garantiza que el tratado se está interpretando en los justos términos en que se concibió y para los que fue diseñado, pues al resultar aplicables a todos los convenios que siguen el modelo

${ }^{20}$ Tesis Aislada CLXXI, 9a. Época; 2a. Sala; Semanario Judicial de la Federación y su Gaceta; Tomo XVI, Diciembre de 2002; Número de Registro 185294 P. 292. 
de la OCDE, se impide que las autoridades fiscales de cada país interpreten los tratados con base en apreciaciones propias y, quizá, empleando métodos diferentes, ya que la existencia de los comentarios las obliga a ajustar su actuación a los lineamientos en ellos previstos y, consecuentemente, a resolver, si no siempre en idénticos términos, sí en forma similar. ${ }^{21}$

El cambio paradigmático que ofrece la aplicación de la metametodología hermenéutica que implica a la complejidad en los convenios de doble imposición nos deja entrever con claridad, lo radical y lo amplio. Se trata, en un sentido, de aquello que sería lo más simple, lo más pueril: cambiar las bases de partida del razonamiento, las relaciones asociativas e intertextuales entre algunos conceptos iniciales, pero de los cuales depende en principio toda la estructura de la argumentación, todos los desarrollos discursivos e interdicursivos posibles.

\section{La metaargumentación en los convenios para evitar la doble tributación}

La metametodología hermenéutica aplicable a los tratados para evitar la doble interpretación, consiste en partir desde la complejidad contemplando la intertextualidad para lograr la más acertada interpretación de ellos, rebasando la explicación óntica y ontológica por el camino de la espacialidad de la globalización construyendo espacios y tiempos en los cuales se funde lo nacional y lo internacional en una multidimensionaldad rica de matices, saberes y metáforas, una de éstas sería la de que la tributación sobre la tributación sería la negación de la proporcionalidad, del contribuyente, materia y período o, en otras palabras, aplicar por el principio de la analogía la máxima romana de non bis in ídem hace siglos acuñada. La metáfora que se basa en descubrir haideggerianamente semejanzas y diferencias, en el campo de los convenios para evitar la doble tributación toma como primer analogado al cumplimiento fiscal, así argumentamos que ya cumplida la exigencia fiscal en un país no procede repetirla conforme lo convenido entre países.

El derecho no puede reducirse a la sola argumentación, pero el enfoque argumentativo del derecho puede contribuir de manera decisiva a una mejor teoría y a una mejor práctica jurídica. Argumentar es algo que tiene lugar en el contexto de la resolución de problemas, aunque la superación de muchos problemas (incluidos los jurídicos) suele requerir otras cualidades, otras habilidades además de argumentar. ${ }^{22}$

Al igual que existen diversas disciplinas que se interesan por la argumentación, podemos encontrarnos también con diversas nociones de argumentación. Por ejemplo los lógicos entienden los argumentos como encadenamien-

${ }^{21}$ Tesis Aislada I.9o.A.76 A, 9a. Época; Tribunal Colegiado de Circuito; Semanario Judicial de la Federación y su Gaceta; Tomo XVIII, Septiembre de 2003; número de Registro 183297 Pág. 1371.

${ }^{22}$ Atienza, Rodríguez, Manuel, Curso de argumentación jurídica, Trotta, Madrid, 2014, pp.108-109. 
tos de enunciados en los que, a partir de algunos de ellos (las premisas), se puede pasar a otro (la conclusión). Pero otros enfoques pueden consistir en ver la argumentación como una actividad o un arte dirigido a establecer o descubrir las premisas; como una técnica dirigida a persuadir a otro de determinada tesis, entre otras más. Esa pluralidad de nociones puede observarse también en el mundo del Derecho, por lo cual existe una contraposición característica entre la manera de ver la argumentación por parte de los precursores ${ }^{23} \mathrm{y}$ de los autores que representan la teoría estándar ${ }^{24}$ de la argumentación jurídica.

La complejidad de la noción de la noción no deriva de que la expresión argumentación sea ambigua. Es decir, para aclarar su significado no basta con mostrar en que sentidos distintos se habla de argumentación sino que habría de ser capaz de explicar qué relación existe entre cada uno de ellos. Logrando así cierta unidad en la diversidad. Los elementos que configuran el concepto de argumentación en un plano muy diverso son: 1. Argumentar es siempre una acción relativa a un lenguaje. Podría decirse que es un uso del lenguaje que se caracteriza por la necesidad de dar razones: se argumenta cuando se defiende o se combate una determinada tesis y se dan razones para ello. Por lo demás hay argumentos, o fragmentos de menos, del lenguaje hablado o escrito. 2. Una argumentación presupone siempre un problema, una cuestión cuya respuesta tiene que basarse en razones apropiadas al tipo de problema de que se trate. 3. Una argumentación supone tanto un proceso, una actividad, como el producto o resultado de esa actividad. Como actividad, la argumentación es todo lo que tienen lugar entre el planteamiento del problema y la solución del mismo; como resultado en una argumentación cabe distinguir siempre estas tres entidades: premisas, conclusiones e inferencia. 4. Argumentar es una actividad racional, en el doble sentido de que es una actividad orientada a un fin y en el que existen criterios para evaluar la calidad de esa actividad. Cuestionándonos si se trata de una argumentación buena o mala, mejor o peor que otra, más sólida o congruente que la que enfrentamos, etcétera. ${ }^{25}$

Existen diversas concepciones de argumentación, Nos referimos a tres formas de interpretar los elementos comunes que definen el concepto de argumentación, lo que nos lleva a tres aproximaciones básicas de la argumen-

\footnotetext{
${ }^{23}$ Lo que caracterizó a los precursores en los años cincuenta del siglo pasado, fue la tesis de que el razonamiento jurídico no podía verse como un tipo de razonamiento deductivo. Así tenemos a Recaséns Siches defendiendo la idea de un logos de lo razonable que contrapuso al logos de lo racional. Otros autores de esta línea son Perelman, Viehweg y Toulmin. Éste último se opuso al estudio tradicional de los argumentos desde un punto de vista puramente formal, en su lugar propuso un enfoque procedimental, dialéctico. Véase Toulmin, Stephen Edelston, Los usos de la argumentación, península, Barcelona, 2007, p. 7.

${ }^{24}$ Los autores que integran la concepción estándar como Alexy, Aarnio, MacCormick, a finales de los setentas ven al razonamiento jurídico ya no contrapuesto al deductivo, sino que destacan que para comprender aquél en toda su complejidad se necesitan otros recursos, además de la lógica en sentido estricto.

${ }^{25}$ Atienza, Rodríguez, Manuel, opus cit., pp.109-110.
} 
tación: la formal, la material y la pragmática. Siendo ésta última la que abordaremos, ya que es la idónea y aplicable a los convenios para evitar la doble imposición. La concepción pragmática contempla la argumentación como un tipo de actividad lingüística, con una serie de actos de lenguaje complejo. Lo que se privilegia entonces no es la sintáctica o semántica del lenguaje sino la pragmática. Dentro de esta concepción pragmática se puede distinguir dos enfoques: uno es el de la retórica y el otro es el de la dialéctica. Así las argumentaciones de Perelman y Toulmin vienen a representar, respectivamente, el punto de vista retórico y dialéctico.

Chaïm Perelman basa su teoría en la forma en que se argumenta delante de un auditorio y el comportamiento ante un grupo de personas a las que se intenta persuadir. Hace un análisis de la forma en que los abogados realizan los razonamientos jurídicos. Basa su teoría tomando las ideas de Aristóteles y Cicerón sobre retórica. Perelman se interesa en la estructura de la argumentación. A diferencia de Aristóteles, el discurso a que se refiere Perelman ya está relacionado con el discurso escrito. ${ }^{26}$ La obra de Perelman, ofrece una construcción de la argumentación desde la perspectiva de quién o ante quién se exponen los argumentos. En tal sentido, la argumentación pasa a ser un proceso interactivo entre el orador y el auditorio, que tiene por finalidad llevar a este último a un estado de creencia, ya sea por persuasión o por convencimiento. Perelman considera que una argumentación es válida si logra el efecto perseguido, esto es, si se produce acuerdo con las proposiciones propuestas.

Por su parte Stephen E. Toulmin, considerado junto con Perelman como otro de los padres de la nueva argumentación, gracias a su libro Los usos de la argumentación también del año de 1958 (obra ampliada en 1982), como buen discípulo de Ludwig Wittgenstein utilizando la lógica inductiva considera que en la jurisprudencia como lógica operativa ella brilla con singular fuerza a partir de la argumentación inductiva, su epistemología incorpora elementos como aserción, contexto, respaldo, cualificador nodal, reserva y garantía, los que por cuestión de espacio no desarrollaremos aquí.

\section{A manera de conclusión}

En la globalización la hermenéutica de los convenios para evitar la doble tributación signados por los diferentes países exige una metaargumentación, que requiere del empleo de la filosofía del lenguaje por el camino de la lingüística y las ciencias del lenguaje, así como el reto de tener un intelecto abierto hacia un nuevo campo inédito en la historia de la humanidad.

${ }^{26}$ Véase, Perelman, Chaïm, Tratado de la Argumentación: la nueva retórica, Gredos, 2009, p. 87. 


\section{Bibliográficas}

\section{REFERENCIAS}

Alexy, RoBert, Teoría de la argumentación jurídica: la teoría del discurso racional como teoría de la fundamentación jurídica, Centro de Estudios Constitucionales, Madrid, 1989.

Atienza, Rodríguez, Manuel, Curso de argumentación jurídica, Trotta, Madrid, 2014.

Hallivis, Manuel, Interpretación de Tratados Internacionales Tributarios, Porrúa, México, 2011.

MoRIn, EdGAR, Introducción al pensamiento complejo, Gedisa, Barcelona, 1991.

Perelman, Chaïm, Tratado de la Argumentación: la nueva retórica, Gredos, 2009.

SAinz de Bujanda, Fernando, "La interpretación en derecho español, de los tratados internacionales para evitar la doble imposición", Revista de Derecho Financiero y Hacienda pública, núm.38, Madrid, junio de 1960.

Toulmin, Stephen E., Los usos de la argumentación, Península, Barcelona, 2007.

\section{Jurisprudencia y Convenios consultados}

Convenio entre los gobiernos de los Estados Unidos Mexicanos y de la República Federativa del Brasil para Evitar la Doble Imposición y Prevenir la Evasión fiscal en Materia de Impuestos sobre la Renta, sitio electrónico de la Secretaría de Hacienda y Crédito Público, ftp://ftp2.sat.gob.mx/asistencia_servicio_ftp/publicaciones/legislacion07/Brasil20070101.pdf

Decreto Promulgatorio del Acuerdo entre los Estados Unidos Mexicanos y la República Federal de Alemania para Evitar la Doble Imposición y la Evasión Fiscal en Materia de Impuestos sobre la Renta y sobre el Patrimonio, firmado en la Ciudad de México, el 9 de julio de 2008.

Cámara de Senadores, Dictamen de las Comisiones Unidas de Puntos Constitucionales y de Estudios Legislativos, con opinión de la Comisión de Reforma del Estado, respecto del Proyecto que modifica diversos artículos de la Constitución Política de los Estados Unidos Mexicanos en materia de derechos humanos, 17 de febrero de 2011.

Tesis Aislada I.9o.A.76 A, 9a. Época; Tribunal Colegiado de Circuito; Semanario Judicial de la Federación y su Gaceta; Tomo XVIII, Septiembre de 2003; número de Registro 183297 Pág. 1371.

Tesis Aislada CLXXI, 9a. Época; 2a. Sala; Semanario Judicial de la Federación y su Gaceta; Tomo XVI, Diciembre de 2002; Número de Registro 185294, p. 292. 



\section{Respecto al levantamiento de una nueva acta de nacimiento para el reconocimiento de la identidad de género: ¿resolución administrativa o resolución judicial? Dr. Eduardo Oliva Gómez*}

Resumen: La reglamentación del levantamiento de una nueva acta de nacimiento para el reconocimiento de la identidad de género, sólo se encuentra regulada en México en la legislación civil para el Distrito Federal y en la legislación familiar para el estado de Sinaloa; en ninguna otra de las legislaciones civiles o familiares de las 30 restantes entidades federativas de la República Mexicana se permite esta modificación en los registros de nacimiento.

Reflexionar sobre la posibilidad jurídica de la modificación de un acta de nacimiento por motivo del reconocimiento de la identidad de género, es sin lugar a dudas, reflexionar sobre el derecho humano a la identidad, a la no discriminación y al respeto de la dignidad humana.

En el presente trabajo, se hace la revisión de la génesis y evolución en el sistema jurídico mexicano de la modificación del acta de nacimiento por el reconocimiento de la identidad de género; aunado a dicho estudio, se aborda el tema bajo la perspectiva que implica el concebir la modificación, a partir de una resolución administrativa o por motivo de una resolución judicial.

Palabras clave: Registro de nacimiento, identidad de género, acto administrativo, resolución judicial.

Abstract: The regulations to issue a new birth certificate which recognizes gender identity in Mexico is only regulated within the civil law for Mexico

* Doctor en Derecho, con mención honorífica, por la Benemérita Universidad Autónoma de Puebla. Director de la División de Estudios Superiores de Posgrado de la Facultad de Derecho y Ciencias Sociales de la Universidad Autónoma del Estado de Morelos. Profesor Investigador de tiempo completo en dicha Facultad. Miembro del Sistema Nacional de Investigadores, nivel I. Autor en diversos artículos, revistas y libros. 
City and in the family law for the State of Sinaloa, in none of the remaining 30 entities of the country is allowed this modification to the birth certificate.

Think over the juridical possibility to modify a birth certificate because of the recognition of gender identity is to think over the human right to identity, no discrimination and the respect to human dignity.

In the following paper, a review on the genesis and evolution of the Mexican legal system on the modification of birth certificates because of the recognition of gender identity, is done. Taken together with this study, the issue is addressed from the perspective that involves conceiving the modification from an administrative act or because of a court decision.

Key words: Birth certificate, gender identity, administrative act, court decision.

\section{Introducción.}

En el sistema jurídico mexicano, en los códigos civiles y de procedimientos civiles, o bien, en los códigos familiares y de procedimientos familiares, para el caso de aquellas entidades federativas en las que ya se reconoce la autonomía e independencia del derecho de familia con respecto al derecho civil, el derecho de familia se regula en códigos propios de la materia, se contempla un título, capítulo o apartado especial destinado a la reglamentación de la aclaración, corrección o modificación de las actas del estado civil de las personas.

Valga citar al respecto, solamente como muestra, el caso del código familiar para el Estado de Morelos ${ }^{1}$, en el que se contiene en el Libro Sexto "Del Registro Civil", el Título Segundo "De la Inscripción, Rectificación y Aclaración de las Actas del Registro Civil”, en el Capítulo IV. De la Rectificación y Aclaración de las Actas del Registro Civil.

En el referido capítulo se regula en su artículo 487 sobre la aclaración de actas del registro civil, indicando que:

"La aclaración de actas del Registro Civil procede cuando en el acta existen errores mecanográficos, manuscritos, ortográficos o de reproducción gráfica, que no afecten los datos esenciales de ésta y deberá tramitarse ante las oficialías del registro civil correspondientes de cada municipio o ante el Director del Registro Civil del Estado de Morelos, siendo éste último, quien resolverá la solicitud y remitirá en su caso, copia certificada de la resolución que recaiga a la Oficialía del Registro Civil correspondiente para su debida inscripción.

En caso contrario, al afectar los datos esenciales será necesaria la rectificación del acta del Registro Civil, para cuyo trámite se requerirá de la intervención del Ministerio Público y se ventilará de acuerdo con lo establecido en los artículos 456 al 461 del Código Procesal Familiar"

${ }^{1}$ Publicado en el Periódico Oficial del Estado "Tierra y Libertad" con fecha 6 de septiembre de 2006, entrando en vigor de acuerdo a lo dispuesto en el artículo segundo transitorio, el día primero de octubre de 2006. Para mayor información, véase, www.transparenciamorelos.mx 
La reglamentación jurídica citada, tal como de su literalidad se indica, puede llevarse a cabo mediante un procedimiento administrativo directamente ante el Registro Civil, sólo cuando la aclaración que se solicita tiene su causa en un error mecanográfico, manuscrito, ortográfico o de reproducción gráfica, supuestos todos que se establece, no afecan los datos esenciales del registro, por tanto, cuando la aclaración tengo un motivo distinto a los especificados, o cuando la aclaración provoque una afectación en los datos esenciales, será necesario llevar el trámite mediante la promoción de un procedimiento judicial ante el Juez de lo Familiar.

Esto así queda precisado de la misma forma en lo que dispone en el código procesal familiar $^{2}$ en los artículos 456 bis y 457 bis al establecer:

“Artículo 456 bis. Las actas del Estado Civil de las personas podrán ser rectificadas o modificada mediante resolución judicial:

I. Cuando los datos a complementar, aclarar, rectificar o modificar alteren sustancialmente los de las personas de cuyo estado civil se trate;

II. Cuando se trate de asuntos en los que se presuma que se altera o afecta la filiación o parentesco con alguna de las personas que se mencionan en el acta relacionadas con el estado civil de la persona cuya acta se pretende rectificar;

III. La modificación parcial o total del nombre de pila o los apellidos de la persona en su acta de nacimiento;

IV. Todos aquellos que por su naturaleza no pueda conocer la Dirección General del Registro Civil"

El artículo 457-bis dispone: "El juicio sobre rectificación o modificación se tramitará en la vía de controversia familiar en contra del Oficial del Registro Civil ante quien consta el acta de que se trata..." y, en el artículo 458 se establece que "El juicio concluirá con el dictado de una sentencia... Una vez ejecutoriada la sentencia, se comunicará al Oficial del Registro Civil para que haga referencia de ella al margen del acta impugnada, sea que el fallo conceda o niegue la rectificación"

La reglamentación comentada contenida en el código familiar y procesal familiar para el Estado de Morelos, es regulada casi en términos similares en la mayoría de los códigos civiles y/o familiares de las diversas entidades federativas, de los que se pueden destacar dos reglas comunes:

La primer regla común es que la rectificación, modificación o aclaración del acta de nacimiento, de los supuestos hipotéticos contemplados, en ninguno se establece la posibilidad que sea susceptible intentarla para efecto del levantamiento de una nueva acta de nacimiento por reasignación para la concordancia sexo-genérica o, por el reconocimiento de la identidad de género, esto es, para que se lleve a cabo el levantamiento de una nueva acta de nacimiento en la que se haga modificación del nombre y sexo de origen con que fue registrada la persona, con la nota de aclaración respectiva en el acta primigenia.

${ }^{2}$ Ibidem. 
El modificar un registro de nacimiento por reasignación o reconocimiento de identidad de género, desde luego que se trata de una corrección que altera sustancialmente los datos esenciales del registro, el modificarla por este supuesto tiene dos efectos inmediatos: el primero de ellos, sin importar desde luego el orden, será que se modifique el nombre de la persona para asignarle otro del género que se reasigna o reconoce y, el segundo, será la modificación del sexo de la persona con el que se le identificaba en el acta de origen.

Esta corrección esencial en el registro de nacimiento, sólo regula su posibilidad y procedencia en el código civil para el Distrito Federal y en el código familiar para el Estado de Sinaloa, con excepción de estas dos legislaciones, las restantes 30 entidades federativas no regulan en sus códigos la procedencia de la reasignación o reconocimiento de identidad de género.

La segunda regla común es que la rectificación, modificación o aclaración del acta de nacimiento, cuando afecte datos esenciales del registro de la persona, debe hacerse forzosamente mediante un procedimiento de tipo judicial, esto es, promoviéndose una demanda ante el juez familiar de primer instancia del Distrito Judicial que corresponda y concluyendo con una resolución judicial dictada por dicha autoridad judicial.

El intentar una modificación en el supuesto de que afecte los datos esenciales del registro, no puede hacerse mediante un procedimiento administrativo ante el oficial del Registro Civil, esta regla es común de las 31 entidades federativas de la República Mexicana, incluyéndose la respectiva del Estado de Sinaloa. La única legislación que permite llevar a cabo el trámite administrativo sin ser necesario recurrir ante el juez, es la del Distrito Federal.

El presente trabajo lo hemos dedicado por una parte para revisar, analizar y reflexionar sobre la modificación de un acta de nacimiento por motivo de la reasignación o reconocimiento de la identidad de género, modificación que desde luego constituye una corrección que afecta los datos esenciales del registro, lo que sólo es posible jurídicamente en el Distrito Federal y en el estado de Sinaloa por así encontrarse regulado. Por otra parte, el tema nos impone plantearnos diversas interrogantes ante las reglas procesales que refieren llevar esta modificación mediante una demanda judicial y, por tanto, lograrlo sólo por efectos de una resolución judicial, ante tales condiciones nos preguntamos: ¿La modificación del acta de nacimiento por reasignación o reconocimiento de identidad de género debe hacerse ante la autoridad administrativa o ante la autoridad judicial? ¿La modificación del acta de nacimiento por reasignación o reconocimiento de identidad de género debe ser producto de una resolución administrativa o de una resolución judicial? ¿Dentro del respeto a los Derechos Humanos será lo correcto dejar esta modificación al 
resultado del procedimiento judicial? ¿Los derechos de intimidad y dignidad de la persona transexual quedan expuestos ante la necesidad de promover una demanda judicial para la obtención de una nueva acta de nacimiento que reconoce su identidad de género?

Las interrogantes que nos planteamos deben reflexionarse, pues el no aceptar que el trámite pueda llevarse a cabo mediante un procedimiento de tipo administrativo, como se hace en muchos otros casos cuando se solicita una modificación que no tiene nada que ver con el género, pone en riesgo los derechos humanos del que lo solicita y atenta contra los derechos de identidad de genero.

Génesis y evolución sobre la reglamentación del levantamiento de una nueva acta de nacimiento por reconocimiento de la identidad de género en el sistema jurídico mexicano.

El levantamiento de una nueva acta de nacimiento por la reasignación para la concordancia sexo-genérica, es reglamentada jurídicamente por primera vez en el sistema jurídico mexicano, en el código civil para el Distrito Federal, por efectos de la reforma publicada en la Gaceta Oficial con fecha 10 de octubre de 2008.

Es importante precisar que su implementación de inicio no fue conceptualizada como "reconocimiento de la identidad de género", el primer momento de la reglamentación la conceptualiza e identifica como "reasignación para la concordancia sexo-genérica".

El artículo 35 reformado en 2008 del código civil de la ciudad capital establece:

“Artículo 35. En el Distrito Federal estará a cargo de los Jueces del Registro Civil autorizar los actos del estado civil y extender las actas relativas a nacimiento, reconocimiento de hijos, adopción, matrimonio, divorcio administrativo y, muerte de los mexicanos y extranjeros en el Distrito Federal, al realizarse el hecho o acto de que se trate, así como inscribir las ejecutorias que declaren la ausencia, la presunción de muerte, el divorcio judicial, la tutela o que se ha perdido o limitado la capacidad legal para administrar bienes y las sentencias que ordenen el levantamiento de una nueva acta por la reasignación para la concordancia sexo-genérica, previa la anotación correspondiente al acta de nacimiento primigenia, siempre y cuando se cumplan con las formalidades exigidas por los ordenamientos jurídicos aplicables". ${ }^{3}$

En concordancia con lo reglamentado, el artículo 135 Bis del referido ordenamiento legal dispone:

3 Véase Código Civil para el Distrito Federal, en http:/www.ordenjurídico.gob.mx/Documentos/ Estatal/Distrito\%Federal/wo29081.pdf 
"Artículo 135 Bis. Pueden pedir el levantamiento de una nueva acta de nacimiento por reasignación de concordancia sexo-genérica, previa la anotación correspondiente en su acta de nacimiento primigenia, las personas que requieran el reconocimiento de su identidad de género.

Se entenderá por identidad de género la convicción personal de pertenecer al género masculino o femenino, es inmodificable, involuntaria y puede ser distinta al sexo original. La reasignación para la concordancia sexo-genérica es el proceso de intervención profesional mediante el cual la persona obtiene concordancia entre los aspectos corporales y su identidad de género, que puede incluir, parcial o totalmente: entrenamiento de expresión de rol de género, administración de hormonas, psicoterapia de apoyo o las intervenciones quirúrgicas que haya requerido en su proceso; y que tendrá como consecuencia, mediante resolución judicial, una identidad jurídica de hombre o mujer, según corresponda.

Se entenderá por expresión de rol de género, el conjunto de manifestaciones relacionadas con la vestimenta, la expresión corporal o verbal y el comportamiento. Los derechos y obligaciones contraídas con anterioridad a la reasignación para la concordancia sexo-genérica no se modifican ni extinguen con la nueva identidad jurídica de la persona"4

Respecto a la tramitación, el código de procedimientos civiles para el Distrito Federal crea un capítulo especial IV Bis, del artículo 498 al 498 BIS-8, "Del Juicio Especial de levantamiento de Acta por Reasignación para la concordancia sexo-genérica".

En dicho capítulo se establece en el artículo 498 que la demanda donde se solicite el levantamiento de la nueva acta de nacimiento, deberá cumplir con los requisitos que debe cumplir toda demanda contemplados en la propia ley procesal y que la misma deberá presentarse ante el juez de lo Familiar.

Establece el artículo 498 BIS-3 que además de los medios de prueba que se aporten, el demandante deberá comparecer a la audiencia respectiva acompañado de los peritos que hayan emitido los dictámenes periciales que acreditan que el solicitante se encuentra sujeto al proceso de reasignación para la concordancia sexo-genérica con un mínimo de 5 meses, dichos peritos deberán acreditar su pericia en materia clínica específicamente en procesos de reasignación de sexo.

El artículo 498 BIS-5 dispone que al concluir la audiencia de ley, se citará a sentencia; por otra parte, de conformidad con el artículo 498 BIS-7, el juez, una vez que la sentencia haya causado ejecutoria, ordenará al juez del Registro Civil que proceda a la anotación correspondiente en el acta primigenia y al levantamiento de la nueva acta de nacimiento.

En dichos términos, la disposición contenida en la ley permite por primera vez en el sistema jurídico mexicano, que la persona pueda solicitar mediante una demanda promovida en un procedimiento judicial ante el juez de lo fa-

${ }^{4}$ Ibidem. 
miliar, que se lleve a cabo, autorice y ordene el levantamiento de una nueva acta de nacimiento, diversa a la que se le levantó al momento de su registro de nacimiento inicial; demanda que se interpone en virtud de que por efecto de haberse sometido la persona, a una serie de intervenciones quirúrgicas y las que correspondan, por medio de las cuales la persona, el demandante, ha logrado la transformación del sexo que por naturaleza gozaba al momento de su nacimiento, persiguiendo con ello, que se levante una nueva acta de nacimiento para que sea concordante con el sexo que ahora representa.

Desde luego que la posibilidad material de lograr la asignación de un sexo distinto al que físicamente se representaba al momento de nacer, es posible, sólo por efectos de los prodigiosos avances de los conocimientos científicos y tecnológicos, que permiten la transformación de la persona respecto al sexo de origen con el que siente es el que le corresponde.

El segundo momento en la implementación del levantamiento de una nueva acta de nacimiento por la reasignación de concordancia sexo-genérica o, reconocimiento de identidad de género en el sistema jurídico mexicano, se presenta en la legislación familiar del estado de Sinaloa.

El código familiar para el estado de Sinaloa ${ }^{5}$, contempla y permite la modificación del acta de nacimiento por el levantamiento de una nueva acta de nacimiento por reasignación de concordancia sexo-genérica; esto así se regula en el Libro Tercero "Del Registro Civil”, en su Título III "De la Nulificación, Reposición, Convalidación, Rectificación y Testadura de las Actas del Registro Civil", Capítulo III "De la Modificación de Actas", que en su artículo 1193 dispone:

"Artículo 1193. Ha lugar a pedir la modificación:

I. Por falsedad, cuando se alegue que el suceso registrado no pasó;

II. Por desacuerdo con la realidad, cuando se demuestre a través de documentos fehacientes, que la persona de que se trata ha sido siempre designada con un nombre distinto del que aparece en su acta de nacimiento;

III. Por enmienda, cuando se solicite variar algún nombre u otro dato esencial que afecte el estado familiar, la filiación, la nacionalidad, el sexo y la identidad de la persona. En cuanto a la fecha de nacimiento, será procedente siempre y cuando la que vaya a establecerse sea anterior a la del registro; $y$,

IV. Cuando el nombre propio sea de evidente afrenta social.

Pueden pedir el levantamiento de una nueva acta de nacimiento por reasignación de concordancia sexo-genérica, previa la anotación correspondiente en su acta de nacimiento primigenia, las personas que requieran el reconocimiento de su identidad de género".

\footnotetext{
${ }^{5}$ Publicado el día 6 de marzo de 2013 en el periódico oficial "El Estado de Sinaloa" y entrando en vigor, de acuerdo al primero transitorio, 30 días después de su publicación. Para mayor información, véase, www.laipsinaloa.gob.mx
} 
Sobre la procedencia de la modificación, establece el artículo 1194: "Pueden pedir la modificación de un acta del estado familiar: I. las personas de cuyo estado se trata...El juicio de modificación de un acta, se seguirá en la forma que establece el código de procedimientos familiares del estado de $\mathrm{Si}$ naloa, no será necesaria resolución judicial, en el caso de cambio de régimen económico al que quedó sujeto el matrimonio..."

En lo referente de manera material al procedimiento, se dispone en el Código de Procedimientos Familiares ${ }^{6}$ del Estado de Sinaloa, en su artículo 414:

"La modificación de un acta del estado familiar, no puede hacerse sino ante el poder judicial y en virtud de sentencia de éste, salvo el caso de reconocimiento que haga un padre de su hija, su hijo y errores no esenciales.

Es Juez competente para conocer de los juicios sobre convalidación, reposición y rectificación de actas del Registro Civil, el de primera instancia de la comprensión en que pasó o debió de haber pasado el acta o el del domicilio del promovente a elección de este último, y se tramitarán conforme a las disposiciones de este Capítulo".

En el capítulo VII "Del Levantamiento de Acta por Reasignación para la Concordancia Sexo-Genérica" se establece en los artículos 434, 436, 439 y 441 en lo conducente:

"Artículo 434. La demanda donde se solicite el levantamiento de una nueva acta de nacimiento por reasignación de concordancia sexo-genérica, previa anotación correspondiente al acta de nacimiento primigenia, deberá cumplir con los requisitos establecidos en los artículos 196 y 197 del presente Código y presentarse ante el Juez".

“Artículo 436. Presentada y admitida la demanda por el Juez se dará vista al Registro Civil del Estado y a la Procuraduría General de Justicia del Estado, a través del Ministerio Público adscrito al juzgado; para que dentro del plazo de cinco días hábiles manifiesten lo que a su derecho convenga".

"Artículo 439. Una vez desahogadas todas las pruebas, se dará la palabra al promovente y al agente del Ministerio Público adscrito para que formulen sus alegatos. Al concluir la audiencia el Juez citará para oír sentencia dentro del plazo de diez días hábiles".

“Artículo 441. El Juez ordenará de oficio, dentro del plazo de cinco días hábiles posteriores a que cause ejecutoria la sentencia favorable, que se realice a favor de la persona la anotación correspondiente al acta de nacimiento primigenia y el levantamiento de una nueva acta de nacimiento por reasignación de concordancia sexo-genérica"

${ }^{6}$ Creado por Decreto número 973, publicado en el Periódico Oficial No. 143 del 27 de noviembre de 2013. Para mayor información, véase, www.stj-sin.gob.mx 
De acuerdo a la normatividad revisada en los respectivos códigos para el Distrito Federal y el estado de Sinaloa, en el momento histórico en que fue implementado en dichas legislaciones el levantamiento de una nueva acta de nacimiento, por efectos de la reasignación de sexo, la tramitación debía llevarse necesariamente mediante un procedimiento judicial, que inicia desde luego, con la interposición de una demanda judicial y que la conclusión será el pronunciamiento de una resolución judicial: una sentencia en la que, según el sentido del fallo de la resolución, se declare el levantamiento de la nueva acta, ordenando al Registro Civil proceder materialmente a ello, o se niegue la procedencia de la pretensión incoada.

"Ante este nuevo texto de la ley, las personas que se han practicado intervenciones quirúrgicas de reasignación genital, han acudido a los Juzgados de lo Familiar del Distrito Federal, a solicitar la rectificación del acta de su nacimiento, con el objeto de que se modificara su nombre de pila para asentarse el nombre que han utilizado en razón al género que actualmente ostentan y de igual forma solicitaron que en el renglón correspondiente al sexo de la persona registrada, se hiciera la rectificación para asentarse su nuevo sexo"

Si bien la implementación del levantamiento de una nueva acta de nacimiento por la reasignación de concordancia sexo-genérica o reconocimiento de identidad de género, ha sido innovadora y destaca el respeto al derecho de la diversidad, de la inclusión y de la dignidad humana en el caso específico de la persona transexual, es de hacer notar que su tramitación en la forma que se encuentra reglamentado en derecho vigente en la legislación del estado de Sinaloa y en la implementación de inicio en la legislación del Distrito Federal, en estas líneas nos preocupa tal supuesto y nos planteamos la interrogante del porqué el deber judicializar este supuesto hipotético e imponer necesariamente el llevar su tramitación por medio de un procedimiento judicial, ¿Por qué no puede llevarse mediante un trámite administrativo? ¿Por qué una resolución judicial y no una administrativa?

Es razonable cuestionarse si en realidad es conveniente que este supuesto deba solicitarse mediante un procedimiento de tipo judicial fundado en la interposición de una demanda y sujeto a todas las formalidades que un proceso judicial requiere.

La referida polémica fue motivo de atención de diversos grupos de legisladores del Distrito Federal ${ }^{8}$, hasta llegar al punto de promoverse ante la Comisión del Gobierno de la Asamblea Legislativa de la ciudad capital de

\footnotetext{
${ }^{7}$ Pérez Carbajal y Campuzano, Hilda. El cambio de nombre de las personas fisicas con relación en la familia. en Patiño Manfer, Ruperto y Ríos Ruiz, Alma de los Ángeles. Coordinadores. Derecho Familiar, Temas de Actualidad. Ed. Porrúa - Facultad de Derecho UNAM. México, 2011, pp. 268 y 269.

${ }^{8}$ Para mayor información, véase las publicaciones de la Coordinación General de Comunicación Social de la Asamblea Legislativa del Distrito Federal del 28-junio-2014 en www.aldf.gob.mx
} 
México, la iniciativa de reformas para garantizar el derecho a la identidad de género a través de un procedimiento administrativo ante el Registro Civil del Distrito Federal.

La iniciativa de referencia pretende derogar el "Juicio Especial de Levantamiento de Acta de nacimiento por Reasignación para la concordancia sexo-genérica" contemplado en el código de procedimientos civiles para el Distrito Federal en sus artículo 498 al 498 BIS-8 y sustituírlo por un procedimiento antel el Registro Civil, como un acto administrativo denominado "De Reconocimiento de Identidad de Género"

Siendo este el estado de la cuestión y repreguntándose las interrogantes planteadas, considero oportuno en estas líneas, previo a formular algunas reflexiones sobre la conveniencia o no de que el referido procedimiento tenga una mejor reglamentación como acto adminstrativo y por tanto el levantamiento de acta de nacimiento sea producto de una resolución administrativa en lugar de una resolución judicial, por cuestiones metodológicas es necesario exponer algunos conceptos de acto administrativo, resolución administrativa y resolución judicial.

\section{La modificiación del acta de nacimiento para el reconocimiento de identi- dad de género: ¿Resolución administrativa? ¿Resolución judicial?}

Resolución es el término genérico con el que se designa las decisiones y medidas de publicidad y ejecución de las leyes, adoptadas por los ministros y otras autoridades administrativas. Las resoluciones se hacen constar por escrito respetando una forma administrativa. ${ }^{9}$

Las resoluciones ${ }^{10}$ se dictan para cumplir las funciones que la ley encomienda a cada servicio público. En cuanto a su ámbito material, la resolución alcanza a todo aquello que complemente, desarrolle o detalle a la ley en la esfera de competencia del servicio público. En cuanto al territorio, las resoluciones pueden tener alcance nacional o local, tratándose de servicios descentralizados.

Cuando se emplea el uso de la expresión en relación con las decisiones que emite un órgano judicial, estamos frente al concepto de resolución judicial.

Las resoluciones judiciales son los actos procesales emitidos por el órgano judicial para decidir la litis que le ha sido planteada por las partes en un procedimiento judicial, la más importante de las resoluciones judiciales es, sin duda alguna, la sentencia definitiva, con la cual se pone de manera formal fin al proceso.

\footnotetext{
${ }^{9}$ www.pina-perez.com/documentos/Glosario.pdf

${ }^{10} \mathrm{http}$ //resolucionleyacuerdo.blogspot.mx/2008/04/que-es-resolucin.html
} 
"Dicen de Pina y Castillo Larrañaga que la actividad de los órganos jurisdiccionales se manifiesta en una serie de actos regulados por la ley y que las resoluciones son la exteriorización de estos actos procesales de los jueces y tribunales, mediante los cuales atienden las necesidades y desarrollo del proceso a su decisión, Agregan que las resoluciones no tienen todas el mismo objeto ni idéntica trascendencia" 11

Héctor Santos señala que "bajo la connotación genérica de actuacines judiciales, se incluyen los actos procesales realizados por el órgano jurisdiccional como son las resoluciones judiciales, y que dentro del concepto genérico, las resoluciones judiciales son los actos realizados por el juzgador para decidir las peticiones de las partes o de los demás participantes dentro del proceso, comprendiéndose los autos, los decretos y las sentencias"12

Para hacer referencia a la resolución administrativa resulta necesario revisar el concepto de acto administrativo, entendiendo como tal, "aquel mediante el cual la autoridad administrativa ejerce, de manera general o particular, las facultades que los ordenamientos le otorgan para satisfacer atribuciones de que está investida su unidad administrativa y puede exigir su cumplimiento"13

Miguel Acosta Romero lo define como "una manifestación unilateral y externa de la voluntad, que expresa una decisión de una autoridad administrativa competente, en ejercicio de la potestad pública. Esta decisión crea, reconoce, modifica, transmite, declara o extingue derechos u obligaciones, es generalmente ejecutivo y se propone satisfacer el interés general"14

Andrés Serra Rojas señala que el acto administrativo es "un acto jurídico, una declaración de voluntad, de deseo, de conocimiento y de juicio, unilateral y externa, concreta y ejecutiva, que constituye una decisión ejecutoria, que emana de un sujeto: la Administración Pública, en el ejercicio de una potestad administrativa, que crea, reconoce, modifica, transmite o extingue una situación jurídica subjetiva y su finalidad es la satisfacción del interés general"15

"Los actos administrativos pueden ser definidos como toda manifestación de voluntad, de juicio, de conocimiento o de deseo realizado por una autoridad administrativa en ejercicio de una potestad administrativa distinta de la potestad reglamentaria"16

\footnotetext{
${ }^{11}$ De Pina, Rafael y Castillo Larrañaga, José. citados por Castillón y Luna, Víctor M. Derecho Procesal Civil. Ed. Porrúa, México, 2004. pp. 209 y 210.

${ }^{12}$ Ibidem.

${ }_{13}$ Margáin Manautou, Emilio. Introducción al Estudio del Derecho Administrativo Mexicano. Ed. Porrúa, México, 1994. p. 79.

${ }_{14}$ Acosta Romero, Miguel, Teoría General del Derecho Administrativo, $3^{\mathrm{a}}$ ed., México, Porrúa, 1979, p.299

15 Serra Rojas, Andrés, Derecho Administrativo, 19ª ed., México, Porrúa, 1998, p. 238.

${ }^{16}$ Zanobini, García de Enterría y TR. Fernandez. Citado por Parejo Alfonso, Luciano. Lecciones de Derecho Administrativo. Ed. Tirant Lo Blanch, España, 2011. p. 402.
} 
Nava Negrete ${ }^{17}$ anota que el acto administrativo, como cualquier otro acto del Estado, es un acto jurídico, el cual implica la voluntad de la administración dirigida a producir efectos de derecho; comenta también que todo acto que provenga de un órgano administrativo, es un acto administrativo, y que si bien el acto administrativo se somete al derecho administrativo esencialmente, también con frecuencia queda sometido al derecho privado, sin dejar por esto de ser un acto administrativo.

La resolución administrativa, que constituye un acto administrativo, puede identificarse como aquella decisión emitida por una autoridad administrativa en un procedimiento que ha sido de su conocimiento, al efecto Luciano Parejo ${ }^{18}$ anota que una de las formas de terminación del procedimiento administrativo es la resolución y que una obligación de la autoridad administrativa es el resolver. La autoridad administrativa debe legalmente pronunciarse y resolver, para lo cual inclusive se impone un plazo máximo legal.

Hechas las precisiones doctrinales respecto a resolución judicial y resolución administrativa y retomar la interrogante relativa al tema sobre si el levantamiento de una nueva acta de nacimiento por reasignación de concordancia sexo-genérica o reconocimiento de identidad de género, debe ser producto de una resolución judicial o de una resolución administrativa.

En la legislación del Distrito Federal, en su código civil, con fecha 5 de febrero de 2015, se publican en su Gaceta Oficial reformas a los artículo 134; 135; 135 Bis; 135 Ter; 135 Quater y 135 Quintus, que desde luego se relacionan con el tema.

Las reformas de referencia respecto al levantamiento de una nueva acta de nacimiento, modifican la reglamentación inicial de octubre de 2008, en la que al implementarse esta figura, su procedencia era por efectos de la reasignación para la concordancia sexo-genérica, en sustitución de ella, ahora, de acuerdo a esta reforma de febrero de 2015 , por efectos de un criterio progresista, el levantamiento de la nueva acta de nacimiento es por efectos del reconocimiento de la identidad de género, lo que desde luego marca una notable evolución en respeto a los derechos humanos del transexual, pues mientras la anterior normatividad hablaba de una concordancia sexo-genérica, la norma vigente se refiere a un reconocimiento de identidad de género, esto es, al respeto al derecho humano de la identidad.

Siendo de gran interés esta reforma, la nota aún más significativa en las referidas reformas se tiene por virtud de que, mientras en la anterior reglamentación (octubre de 2008) el procedimiento para el levantamiento de la nueva

17 Confront. Nava Negrete, Alfonso. Derecho Administrativo Mexicano. Ed. Fondo de Cultura Económica, México, 2001. pp. 351, 352 y 353.

${ }_{18}$ Parejo Alfonso, Luciano. op. cit. p. 378. 
acta de nacimiento por reasignación para la concordancia sexo-genérica, debería ser mediante la interposición de una demanda judicial ante la autoridad judicial, juez de lo familiar y el levantamiento se lograba por la resolución judicial emitida en el procedimiento respectivo; la reforma de febrero de 2015 desjudicializa el procedimiento y bajo una concepción a destacar, establece que el procedimiento no será ya judicial y, por tanto, aquella persona que requiera el levantamiento de una nueva acta de nacimiento para el reconocimiento de su identidad de género, lo solicitará directamente ante la autoridad administrativa, Registro Civil.

Dice en lo conducente el artículo 134 reformado que: "La rectificación de un acta del estado civil no puede hacerse sino ante el Juez del Registro Civil...” y dice el artículo 135-Bis dice que “...El reconocimiento respectivo se llevará a cabo ante las instancias y las autoridades correspondientes del Registro Civil del Distrito Federal cumpliendo todas las formalidades que exige el reglamento del Registro Civil del Distrito Federal..."

Con la reforma al código civil, el levantamiento de la nueva acta de nacimiento para efectos del reconocimiento de la identidad de género, deja ya de ser un procedimiento judicial y su levantamiento, se logra por una resolución administrativa seguida mediante un trámite de la misma especie.

\section{Reflexiones Finales}

Se ha comentado en las líneas que anteceden, que el procedimiento de modificación, corrección o aclaración de un acta de nacimiento, cuando afecta los datos esenciales del registro, debe solicitarse, de acuerdo a lo reglamentado en la legislación respectiva de cada una de las 31 entidades federativas de la República Mexicana, con excepción de la respectiva para el Distrito Federal, mediante un procedimiento judicial que inicia con la promoción de una demanda ante el Juez en materia de familia, lo que implica entonces, que la modificación será necesariamente efecto de una resolución judicial.

La problemática jurídica y material que presenta el exigir que la modificación en este supuesto, sea producto de una resolución judicial, impone la necesidad de llevar a cabo el procedimiento judicial que, por una parte, requiere forzosamente de la asesoría e intervención de un abogado que aplica sus conocimientos y pericia en la tramitación del procedimiento respectivo y que, desde luego, resulta necesaria su participación, pues no sería explicable ni comprensible el pensar que un procedimiento judicial pueda llevarse a cabo sin la participación del licenciado en Derecho. Un abogado es el profesionista calificado en los conocimientos para lograr el impulso y continuidad de un 
proceso judicial; su participación se traduce, desde luego, en la necesidad de cubrir sus honorarios que justamente le corresponden por su participación.

Aunado a la participación de este profesionista, la tramitación de un proceso judicial implica invertir un tiempo considerable; todo proceso judicial por regla general es tardado y con ello costoso, no debiendo dejar al margen de este escenario, los riesgos que todo proceso judicial impone; la resolución que se dicta puede ser de dos sentidos: concediendo lo demandado, pero también puede emitirse negando lo demandado.

El procedimiento judicial específico, requiere además, como lo establece la ley, de la participación de peritos médicos que, desde luego, también generan gastos que al agregarse a todos los que ya se han planteado, hacen que en muchos casos, para muchas personas, sea inaccesible el recurrir a la tramitación judicial; no todas las personas cuentan con los recursos necesarios para lograr sostener el seguimiento y conclusión de un procedimiento judicial.

Ante estas particularidades propias del procedimiento judicial, surge la propuesta de regular este tipo de solicitudes mediante un trámite administrativo que, además de provocar la desjudicialización, y con ello el desahogo de la excesiva carga de trabajo que enfrenta la autoridad judicial, evita las consecuencias descritas y la modificación del acta se logra mediante una resolución administrativa en lugar de la resolución judicial.

El procedimiento para el levantamiento de una nueva acta de nacimiento por reconocimiento de la identidad de género, persigue el cumplimiento de un fin en atención a la naturaleza jurídica del mismo, éste es, el facilitar las oportunidades para que, el derecho a la identidad de género, traducido y entendido como un Derecho Humano, sea procurado, protegido, reconocido y respetado en beneficio y en favor del transexual y, por tanto, cualquier complicación, dificultad, rigorismo y complejidad en su consecución, se traduce en una violación a la eficacia material del Derecho Humano al disfrute del reconocimiento de la identidad de género.

El regular y permitir que el procedimiento sea de tipo administrativo, que evita todas las inconveniencias del procedimiento judicial; que evita un procedimiento tardado y que evita una serie de gastos que pueden llegar a ser muy elevados, permite, ocasiona y provoca que el levantamiento de la nueva acta de nacimiento sea una realidad jurídica en toda persona que requiere el reconocimiento de su identidad de género.

El permitir y regular que el levantamiento de la nueva acta de nacimiento sea efecto de una resolución administrativa, se traduce de manera inmediata y directa en el respeto al Derecho Humano del transexual, en el reconocimiento de su identidad de género y provoca el efecto del respeto a su intimidad y a su 
dignidad humana, porque al final, lo que importa es la protección y respeto a este derecho humano y, si el procedimiento administrativo y consecuentemente la resolución administrativa facilita la satisfacción de este derecho, no hay razón alguna para justificar que su obtención se logre mediante otra forma. 


\section{REFERENCIAS}

Acosta Romero, Miguel, Teoría General del Derecho Administrativo, $3^{\mathrm{a}}$ ed., México, Porrúa, 1979.

Castillón y Luna, Víctor M. Derecho Procesal Civil. Ed. Porrúa, México, 2004.

Margáin Manautou, Emilio. Introducción al Estudio del Derecho Administrativo Mexicano. Ed. Porrúa, México, 1994.

Nava Negrete, Alfonso. Derecho Administrativo Mexicano. Ed. Fondo de Cultura Económica, México, 2001.

Parejo Alfonso, Luciano. Lecciones de Derecho Administrativo. Ed. Tirant Lo Blanch, España, 2011.

Patiño Manfer, Ruperto y Ríos Ruiz, Alma de los Ángeles. Coordinadores. Derecho Familiar, Temas de Actualidad. Ed. Porrúa - Facultad de Derecho UNAM. México, 2011.

Serra Rojas, Andrés, Derecho Administrativo, 19ª ed., México, Porrúa, 1998.

\section{Electrónicas}

www.transparenciamorelos.mx

www.laipsinaloa.gob.mx

www.stj-sin.gob.mx

www.aldf.gob.mx

www.pina-perez.com/documentos/Glosario.pdf

http://resolucionleyacuerdo.blogspot.mx/2008/04/que-es-resolucin.html

http://www.ordenjurídico.gob.mx/Documentos/Estatal/Distrito\%Federal/ wo29081.pdf 
ESPAÑA 



\section{Los administrados como titulares de derechos y garantías en sus relaciones con la administración tributaria en España Pedro José Carrasco Parrilla*}

Resumen: El artículo 31 de la Constitución Española consagra el deber de contribuir al sostenimiento de los gastos públicos de acuerdo con la capacidad económica. Sobre la base de este precepto, el interés en la recaudación de los tributos, con los que hacer frente al sostenimiento de las cargas públicas, estaría legitimando que se establezcan limitaciones legales a los derechos de los ciudadanos. En este trabajo se tratará de exponer lo sucedido en España en relación con los derechos y garantías de los administrados en sus relaciones con la Administración tributaria, constituyendo un hito la aprobación de la Ley de Derechos y Garantías de los Contribuyentes, cuyo texto en gran parte ha sido incorporado a la Ley General Tributaria.

Palabras clave: Administración tributaria. Derechos y garantías contribuyentes. Procedimientos tributarios.

Abstract: The Spanish Constitution in Article 31 establishes a duty to contribute to sustain public expenditure according to the economic capacity. Based on this provision, interest in the collection of taxes, dealing with the maintenance of public expenditure, which would legitimize legal rights of citizens established limitations. This paper will attempt to explain what happened in Spain in relation to the rights and guarantees of the governed in

* Universidad de Castilla-La Mancha, Centro Internacional de Estudios Fiscales, Profesor Titular de Derecho Financiero y Tributario en dicha universidad y decano de la misma en el campus Toledo. 
their relations with the tax authorities, constituting a milestone approval of the Bill of Rights and Guarantees of the Taxpayers, the text largely the text largely has been incorporated into the General Tax Law.

Key words: Tax administration. Taxpayer rights and guarantees. Tax procedures.

\section{I.Presentación.}

Con esta colaboración trataremos de aportar alguna reflexión sobre los derechos y garantías de los administrados en sus relaciones con la Administración Tributaria, así como de exponer la situación en la que se encuentran en la actualidad en el seno de los procedimientos tributarios llevados a cabo en España.

Consideramos que el conflicto que necesariamente se produce entre los derechos y privilegios de la Administración Tributaria, y los derechos individuales de los ciudadanos como contribuyentes, no es tanto en la relación sustantiva de los tributos sino en los procedimientos de aplicación de los tributos.

La Constitución Española establece en su artículo 31 el deber de todos a contribuir al sostenimiento de los gastos públicos de acuerdo con su capacidad económica mediante un sistema tributario justo, inspirado en los principios de igualdad y progresividad, así como que este sistema tributario en ningún caso será confiscatorio.

No obstante, el Tribunal Constitucional español, partiendo de lo preceptuado en este art.31 de la Constitución ha establecido que el interés fiscal, esto es, el interés a la recaudación de los tributos (con los que hacer frente al sostenimiento de los gastos públicos) legitima que se establezcan limitaciones legales a los derechos de los ciudadanos, inclinando de este modo la balanza hacia la vertiente colectiva frente a los derechos individuales de los ciudadanos. En este sentido, en su Sentencia 76/1990, de 26 de abril, en relación con la posible vulneración del principio de igualdad en los diferentes tipos de interés que deben abonar los contribuyentes, en una cuantía superior, cuando se retrasan en el pago de sus tributos y el que debe satisfacer la Administración, en una cuantía inferior, cuando ésta se retrasa en las devoluciones de ingresos indebidamente satisfechos a la misma, al señalar el Tribunal Constitucional que se trata de evitar el perjuicio de que grupos de contribuyentes dejaran de pagar, parece encontrar su justificación en el art.31.1 CE, esto es, en el interés público en la recaudación de los tributos; y en este sentido, expresa el Fundamento 
Jurídico Tercero de esta Sentencia que el deber de contribuir al sostenimiento de los gastos públicos es un deber de los ciudadanos que implica "más allá del genérico sometimiento a la Constitución y al resto del ordenamiento jurídico que el artículo 9.1 de la norma fundamental impone, una situación de sujeción y de colaboración con la Administración tributaria en orden al sostenimiento de los gastos públicos cuyo indiscutible y esencial interés público justifica la imposición de limitaciones legales al ejercicio de los derechos individuales".

\section{II.Necesidad de disponer de una ley que regulara los derechos y garantías de los administrados en sus relaciones con la administración tributaria.}

La antigua Ley General Tributaria española era del año 1963. En el año 1985 se lleva a cabo una modificación de la Ley General Tributaria ${ }^{1}$ que redujo las garantías de los contribuyentes y tuvo como consecuencia un aumento tanto de la litigiosidad como de defraudación tributaria. Las sanciones tributarias aumentaron su cuantía considerablemente, prefiriendo acudir el contribuyente a la vía penal y enfrentarse a un proceso por delito fiscal, a ser sancionado en vía administrativa.

El 26 de noviembre de 1992 se aprueba la Ley 30/1992, de Régimen Jurídico de las Administraciones Públicas y del Procedimiento Administrativo Común, en cuyo articulado se reconocen los derechos de los ciudadanos en sus relaciones con las Administraciones Públicas. No obstante, en su Disposición Adicional Quinta, titulada "Procedimientos administrativos en materia tributaria", en su versión original, dispuso que: "1.Los procedimientos administrativos en materia tributaria $\mathrm{y}$, en particular, los procedimientos de gestión, liquidación, comprobación, investigación y recaudación de los diferentes tributos se regirán por su normativa específica y, subsidiariamente, por las disposiciones de esta Ley. 2. La revisión de actos en vía administrativa en materia tributaria se ajustará a lo dispuesto en los artículos 153 a 171 de la Ley General Tributaria y disposiciones dictadas en desarrollo y aplicación de la misma". Aunque el intento de excluir al menos parcialmente la aplicación de los derechos y garantías consagrados en la Ley 30/1992 a la materia tributaria quedaba patente, no faltaron voces críticas contra esta exclusión ${ }^{2}$.

\footnotetext{
${ }^{1}$ Reforma operada por la Ley 10/1985, de 26 de abril, de modificación parcial de la Ley General Tributaria de 1963.

2 Vid., por todos: Parejo Alfonso, L.: “Objeto, ámbito de aplicación y principios generales de la Ley de Régimen Jurídico de las Administraciones Públicas y del Procedimiento Administrativo Común”, en Leguina Villa, J., y Sánchez Morón, M. (dirs.): La nueva Ley de Régimen Jurídico de las Administraciones Públicas y del Procedimiento Administrativo Común, Ed.Tecnos, Madrid, 1993, pág.27 y ss.
} 
Años más tarde, la Ley 4/1999, de 13 de enero, de modificación de la Ley 30/1992, modifica la citada Disposición Adicional Quinta en un intento de dejar patente lo específico de la materia tributaria, pues así lo expresa su exposición de motivos: "con el fin de reforzar la especificidad de los procedimientos tributarios dentro de la necesaria armonía con los principios comunes al régimen jurídico y procedimiento de las Administraciones públicas", quedando redactada del siguiente tenor: "1.Los procedimientos tributarios y la aplicación de los tributos se regirán por la Ley General Tributaria, por la normativa sobre derechos y garantías de los contribuyentes, por las Leyes propias de los tributos y las demás normas dictadas en su desarrollo y aplicación. En defecto de norma tributaria aplicable, regirán supletoriamente las disposiciones de la presente Ley. En todo caso, en los procedimientos tributarios, los plazos máximos para dictar resoluciones, los efectos de su incumplimiento, así como, en su caso, los efectos de la falta de resolución serán los previstos en la normativa tributaria. 2.La revisión de actos en vía administrativa en materia tributaria se ajustará a lo dispuesto en los artículos 153 a 171 de la Ley General Tributaria y disposiciones dictadas en desarrollo y aplicación de la misma"3.

La Ley 25/1995, de 20 de julio, vuelve a modificar parcialmente la Ley General Tributaria de 1963. Entre sus aspectos positivos destacan, presidido por el objetivo principal de la reforma, incentivar el cumplimiento voluntario, incluso fuera de los plazos establecidos, de las obligaciones tributarias. También se procedió a una reducción de las sanciones, así como a plasmar en la norma el criterio establecido por los Tribunales de que el contribuyente que en su actuación administrativa se ajustara al criterio de la Administración, quedaba exonerado de responsabilidad. Ahora bien, al reforzarse las competencias comprobadoras de los órganos de gestión tributaria, frente a los órganos de inspección tributaria (hasta entonces no sólo comprobaban, sino que también liquidaban y sancionaban); el problema es que ese reforzamiento de estas competencias por parte de los órganos de gestión no se había acompañado de una delimitación clara de las competencias de unos y otros órganos, lo cual genera cierta inseguridad.

\footnotetext{
3 En esta misma línea se expresa la Ley 39/2015, de 1 de octubre, del Procedimiento Administrativo Común de las Administraciones Públicas, que deroga la Ley 30/1992, aunque con efectos de 2 de octubre de 2016 (según establece su disposición derogatoria única 2.a), en la que se detalla una serie de actuaciones y procedimientos que se regirán por su normativa específica y supletoriamente por lo previsto en esta Ley, entre las que cabe destacar las de aplicación de los tributos y revisión en materia tributaria y aduanera, así como las actuaciones y procedimientos sancionadores en materia tributaria y aduanera.
} 


\section{III.Aprobación de la ley 1/1998, de 26 de febrero, de derechos y garantías de los contribuyentes.}

La Ley 1/1998, de Derechos y Garantías de los Contribuyentes ${ }^{4}$ supuso un avance fundamental en este ámbito. Aprobada el 26 de febrero del año 1998, fue derogada tras la incorporación de sus preceptos en la vigente Ley General Tributaria (Ley 58/2003, de 17 de diciembre, que entró en vigor el 1 de julio de $\left.2004^{5}\right)$.

La Ley de Derechos y Garantías de los Contribuyentes hacía referencia en dos ocasiones, en su exposición de motivos, a que con ella se pretendía reforzar el equilibrio de posiciones entre la Administración y el contribuyente. Es decir, la Ley de Derechos y Garantías de los Contribuyentes de alguna forma trataba de corregir ese enfoque que, como hemos indicado anteriormente, hace el Tribunal Constitucional español cuando viene a afirmar que el interés fiscal, el interés en la recaudación de los tributos, justifica que el legislador conceda una serie de potestades a la Administración, de forma que la Administración es una potentior persona que no está en un plano de igualdad con el contribuyente, sino en un plano de superioridad (STC 76/1990) ${ }^{6}$.

\footnotetext{
${ }^{4}$ Esta ley fue conocida bajo la denominación de "Estatuto del Contribuyente". Por lo que se refiere a la oportunidad de su denominación estatutaria hay que indicar que para poder llevarse a cabo con precisión, en esta Ley, además de establecerse los derechos de los contribuyentes, deberían haberse incluido las obligaciones que, como indicaba su Exposición de Motivos, "aparecen debidamente establecidas en los correspondientes textos legales y reglamentarios". Como señaló Palao Taboada, "el término «estatuto» puede sugerir la idea de que la condición de contribuyente constituye un status (de aquí la palabra) especial del ciudadano, como el de funcionario o militar, sometido frente a la Administración a una relación especial de sujeción, cuando lo cierto es que en un Estado de Derecho las obligaciones tributarias materiales derivan directamente de la Ley, y las formales y las potestades administrativas están dirigidas exclusivamente a la aplicación de las primeras. En otras palabras, no existe una condición de contribuyente separable de la genérica condición de ciudadano"; cfr.: Palao Taboada, C.: "Lo «blando» y lo «duro» del Proyecto de Ley de Derechos y Garantías de los Contribuyentes", Rev.Estudios Financieros, n¹71, 1997, pág.5. Vid., también, sobre la misma cuestión, Ferreiro Lapatza, J.J.: "El Estatuto del contribuyente", Civitas, REDF, nº88, 1995, pág.646.

${ }^{5}$ No obstante, la Disposición Final Undécima de esta Ley dispone que el apartado 2 de la disposición transitoria cuarta entrará en vigor al día siguiente de la publicación de esta Ley en el Boletín Oficial del Estado, esto es, el 19 de diciembre de 2003. El citado apartado dispone la obligación de que los procedimientos sancionadores en materia tributaria iniciados antes del 1 de julio de 2004 deberán concluir antes del 31 de diciembre de 2004, sin que les sea de aplicación el plazo máximo de resolución previsto en el apartado 3 del artículo 34 de la Ley 1/1998, y en el artículo 36 del ya derogado Real Decreto 1930/1998, de 11 de septiembre, por el que se desarrolla el régimen sancionador tributario y se introducen las adecuaciones necesarias en el Real Decreto 939/1986, de 25 de abril, por el que se aprueba el Reglamento General de la Inspección de los Tributos.

${ }^{6}$ Acerca del carácter de potentior persona de la Administración seguirá pronunciándose el TC en las Sentencias 164/1995, 171/1995, 198/1995 y 44/1996. Sin embargo, en la STC 69/1996, de 18 de abril, a la que seguirán las SSTC 23/1997, de 11 de febrero, y 141/1997, de 15 de septiembre, se abandonará esta argumentación; si bien, los asuntos enjuiciados no guardaban relación con el diferente tipo de interés sino con el devengo de los intereses contemplados en el art.45 de la anterior Ley General Presupuestaria de 1988, afirmándose en el FJ5 de la Sentencia 69/1996
} 
Prueba evidente de que la Ley de Derechos y Garantías de los Contribuyentes trata de establecer ese equilibrio la encontramos en el ámbito precisamente de los intereses de demora, pues desde su entrada en vigor se exigen los mismos intereses para ambas partes.

En su exposición de motivos se establecía que en esta Ley se van a regular los derechos y garantías que se establecen por la Ley 30/1992, que establece el régimen jurídico de las Administraciones Públicas y el procedimiento administrativo común, en la que se recogen una serie de derechos que tiene todo administrado frente a cualquier Administración.

Tal vez parece como si el legislador fiscal deseara afirmarse frente al Derecho Público General, frente al Derecho Administrativo, para de este modo marcar su propia autonomía científica. Sin embargo, el Derecho Tributario es una rama del Derecho y por consiguiente no puede separarse del Derecho Común. Parecería como que el legislador tributario entendiera que para que sean aplicados en el ámbito tributario ciertos derechos y garantías que consagra la legislación administrativa (Ley 30/1992), tienen que estar regulados en una ley tributaria?

que "una vez perfeccionada la relación jurídica, cualesquiera que fueren su naturaleza, pública o privada y su origen o fuente, la autonomía de la voluntad o la Ley e incluso aunque fuere el reflejo final del ejercicio de una potestad como la tributaria o la sancionadora, la Hacienda es ya uno de sus sujetos activo o pasivo, sin una posición preeminente ni prerrogativa exorbitante alguna, como sucede con el procedimiento para el pago, sometido a los principios de legalidad presupuestaria y de contabilidad pública. No se trata ahora de la cuantía de los intereses, incógnita ya despejada, ni del cómo, el procedimiento para hacerlos efectivos, sino del elemento temporal, el cuándo, que sirve para perfilar en la realidad su función compensatoria. Aquí, por tanto, desaparecen cualesquiera de las «especialidades» a las cuales alude para respetarlas la Ley de Enjuiciamiento Civil (art.921). No hay, pues, una razón constitucionalmente relevante para justificar un distinto trato en el devengo del interés de demora, según la posición que ocupe la Hacienda pública y sólo por ella", lo cual es un avance con respecto a lo consagrado en la STC 76/1990 y las posteriores citadas. No obstante, en la citada STC 23/1997, va a dejar clara la situación de superioridad que existe a la hora de determinar la cuantía de los intereses de demora, distinta, como se deduce de la STC 69/1996, de la que se hace eco esta Sentencia, de la situación contemplada en el art.45 LGP, coincidente con el art.24 de la vigente Ley 47/2003, de 27 de noviembre, General Presupuestaria. En efecto, se establece en el FJ5 de la Sentencia de 1997: "Este Tribunal ha declarado, desde luego, la constitucionalidad de diversas prerrogativas o de situaciones de superioridad, en general, a las Administraciones Públicas, pero siempre a partir de la existencia de algún bien o principio constitucional cuya preservación justificara su reconocimiento. Así, respecto de la autotuleta, con fundamento en el principio de eficacia (SSTC 22/1984, 148/1993 y 78/1996), o de los intereses a favor de la Hacienda por el impago de los tributos, para evitar riesgos en el funcionamiento del sistema tributaria (STC 76/1990); del mismo modo, ha atendido a la demora inercial o institucional de la Hacienda para justificar una menor cuantía de los intereses procesales que ha de satisfacer (STC 206/1993)". Pero, continúa afirmando el TC, "en el caso que nos ocupa no es posible encontrar ningún bien o principio constitucional cuya protección exija el trato privilegiado otorgado". En los mismos términos, y reproduciendo esta Sentencia, se expresa la citada STC 141/1997. Para un estudio más profundo del tema puede consultarse: Carrasco Parrilla, P.J.: Consecuencias del retraso en el pago de las deudas tributarias, Ed.Servicio de Publicaciones de la Universidad de Castilla-La Mancha, Cuenca 2000.

${ }^{7}$ Como ha quedado patente en este trabajo, la propia Ley 30/1992 se encargó, en su versión 
No obstante, el haber recogido los derechos y garantías de los contribuyentes en un único cuerpo legal, fue algo positivo, pues supuso un reforzamiento de la seguridad jurídica, pues la misma exige la certeza del Derecho, que los ciudadanos, como contribuyentes, conozcan el Derecho aplicable. Seguridad jurídica que se pone de manifiesto también en la norma que establece que las leyes y reglamentos que contengan normas tributarias, tienen que mencionarlo expresamente en su título, si bien es cierto que este mandato ni se ha cumplido en su totalidad con la Ley de derechos y garantías de los contribuyentes ni con la vigente Ley General Tributaria que dispone lo mismo en su artículo 9.1.

Ahora bien, no incorporó el derecho de acudir al Consejo de Defensa del Contribuyente, a pesar de que esta Ley se aprobara con posterioridad al Decreto 2458/1996, de 2 de diciembre que creaba el Consejo de Defensa del Contribuyente ${ }^{8}$ (en cambio, sí se refiere al mismo el artículo 34.2 de la vigente Ley General Tributaria que incorpora los derechos y garantías de los contribuyentes reconocidos por la Ley 1/1998).

Finalmente, y como aspecto destacable, la Ley de derechos y garantías de los contribuyentes redujo el plazo de prescripción tributaria en España de cinco a cuatro años.

\section{La ley general tributaria de 2003 y los derechos y garantías de los contribuyentes.}

Con la aprobación de la vigente Ley General Tributaria, Ley 58/2003, de 17 de diciembre, se incorporan los derechos y garantías de los contribuyentes reconocidos por la Ley 1/1998 a lo largo de su articulado.

En concreto, el artículo 34 de la Ley General Tributaria se refiere a los derechos y garantías de los obligados tributarios ${ }^{9}$, incluyendo una lista

original y en la actual, de excluir de su ámbito de aplicación a los procedimientos administrativos en materia tributaria. Lo mismo puede afirmarse de la Ley 39/2015, de Procedimiento Administrativo Común de las Administraciones Públicas.

${ }^{8}$ Actualmente regulado por el Real Decreto 1676/2009, de 13 de noviembre.

9 Término con el que estamos más de acuerdo -y sobre el que ya tuvimos ocasión de manifestarnos a favor de su utilización frente al de "contribuyentes", con ocasión de unos comentarios a la Ley 1/1998, en: Carrasco Parrilla, P.J.: "Comentarios a la Ley 1/1998, de Derechos y Garantías de los Contribuyentes", La Ley, Revista Jurídica española de doctrina, jurisprudencia y bibliografía, $\mathrm{n}^{\circ} 1$, 1991, págs.1873-1878, ya que la utilización de la expresión "contribuyentes" merece una aclaración, que asimismo se encargaba también de ofrecernos la propia Ley 1/1998, en el apartado tercero de su art.1, cuando establecía que: "Las referencias que en esta Ley se realizan a los contribuyentes se entenderán, asimismo, aplicables a los restantes sujetos pasivos, retenedores, obligados a ingresar a cuenta, responsables, sucesores en la deuda tributaria, representantes legales o voluntarios y obligados a suministrar información o a prestar colaboración a la Administración tributaria". En efecto, el significado del término "contribuyentes" se enmarca, 
abierta de los mismos, siendo su contenido el siguiente:

"1. Constituyen derechos de los obligados tributarios, entre otros, los siguientes:

a) Derecho a ser informado y asistido por la Administración tributaria sobre el ejercicio de sus derechos y el cumplimiento de sus obligaciones tributarias $^{10}$.

b) Derecho a obtener, en los términos previstos en esta ley, las devoluciones derivadas de la normativa de cada tributo y las devoluciones de ingresos indebidos que procedan, con abono del interés de demora previsto en el artículo 26 de esta ley, sin necesidad de efectuar requerimiento al efecto.

c) Derecho a ser reembolsado, en la forma fijada en esta ley ${ }^{11}$, del coste

en el contexto general de nuestro sistema tributario, dentro del art.36.2 de la LGT, mientras que el artículo 35 de la LGT dispone una lista abierta de lo que se consideran "obligados tributarios". Por contra, la Ley 1/1998 le atribuía un sentido distinto, más amplio, que venía a coincidir con lo que se conoce como "obligados tributarios", término utilizado por el art.1 del borrador del Anteproyecto de Ley de Derechos y Garantías de los Contribuyentes, de 28 de octubre de 1996, y que afortunadamente asume rango legal con la vigente Ley General Tributaria al intitular su artículo 34 "derechos y garantías de los obligados tributarios", ya que en el mismo se incluyen a todas las personas que pueden tener relación con las Administraciones tributarias. Aunque refiriéndose a la Ley 1/1998, se mostró partidario de utilizar el término "ciudadanos" Alonso Murillo, F.: "Comentario al artículo 1", en Alonso Murillo, F., Blasco Delgado, C., Gómez Cabrera, C, y López Martínez, J.: Comentarios a la Ley de Derechos y Garantías de los Contribuyentes, Ed.Mc.Graw-Hill, Madrid, 1998, págs.16 y 17, donde admitiendo que el término "obligados tributarios" es más adecuado técnicamente que el de "contribuyentes", considera que tampoco está exento de problemas, debido a la "dificultad de precisar sus contornos exactos y dada la insuficiente utilización del mismo por las leyes tributarias". Sin embargo, y con respecto a estas últimas afirmaciones, entendemos que el empleo del término "obligados tributarios" no hubiera dado lugar a confusiones terminológicas y habría servido para generalizar su utilización en el sentido que ya se extraía del art.10 Reglamento General de Recaudación de 1990, sustituido en la actualidad por el vigente Reglamento aprobado por Real Decreto 939/2005, de 29 de julio.

10 En relación con este derecho cabe citar la Sentencia de la Audiencia Nacional de 2 de febrero de 2011 (JT\2011\95), en la que se establece, en su Fundamento Jurídico Segundo que "La Ley lo configura como un "derecho" del contribuyente en el elenco de los derechos que enumera, no como una "obligación" de la Administración, es decir, que ejercido el derecho por el contribuyente a ser informado, se vulnera dicho derecho si la Administración hace caso omiso de la consecuencia derivada del ejercicio de ese derecho, el de ser informado. Quiere precisarse con ello que la obligación de la Administración se hace depender del ejercicio del derecho, pues supone una respuesta a la pretensión de conocimiento de datos a la Administración".

${ }^{11}$ El artículo 33 de la LGT desarrolla este derecho, bajo la rúbrica "Reembolso de los costes de las garantías" con el siguiente contenido:

1. La Administración tributaria reembolsará, previa acreditación de su importe, el coste de las garantías aportadas para suspender la ejecución de un acto o para aplazar o fraccionar el pago de una deuda si dicho acto o deuda es declarado improcedente por sentencia o resolución administrativa firme. Cuando el acto o la deuda se declare parcialmente improcedente, el reembolso alcanzará a la parte correspondiente del coste de las garantías.

2. Con el reembolso de los costes de las garantías, la Administración tributaria abonará el interés legal vigente a lo largo del período en el que se devengue sin necesidad de que el obligado tributario lo solicite. A estos efectos, el interés legal se devengará desde la fecha debidamente acreditada en que se hubiese incurrido en dichos costes hasta la fecha en que se ordene el pago. 3. Lo dispuesto en el presente artículo no será de aplicación respecto de las garantías establecidas por la normativa propia de cada tributo para responder del cumplimiento de las obligaciones tributarias. 
de los avales y otras garantías aportados para suspender la ejecución de un acto o para aplazar o fraccionar el pago de una deuda, si dicho acto o deuda es declarado total o parcialmente improcedente por sentencia 0 resolución administrativa firme, con abono del interés legal sin necesidad de efectuar requerimiento al efecto, así como a la reducción proporcional de la garantía aportada en los supuestos de estimación parcial del recurso o de la reclamación interpuesta.

d) Derecho a utilizar las lenguas oficiales en el territorio de su comunidad autónoma, de acuerdo con lo previsto en el ordenamiento jurídico.

e) Derecho a conocer el estado de tramitación de los procedimientos en los que sea parte.

f) Derecho a conocer la identidad de las autoridades y personal al servicio de la Administración tributaria bajo cuya responsabilidad se tramitan las actuaciones y procedimientos tributarios en los que tenga la condición de interesado.

g) Derecho a solicitar certificación y copia de las declaraciones por él presentadas, así como derecho a obtener copia sellada de los documentos presentados ante la Administración, siempre que la aporten junto a los originales para su cotejo, y derecho a la devolución de los originales de dichos documentos, en el caso de que no deban obrar en el expediente.

h) Derecho a no aportar aquellos documentos ya presentados por ellos mismos y que se encuentren en poder de la Administración actuante, siempre que el obligado tributario indique el día y procedimiento en el que los presentó.

i) Derecho, en los términos legalmente previstos, al carácter reservado de los datos, informes o antecedentes obtenidos por la Administración tributaria, que sólo podrán ser utilizados para la aplicación de los tributos o recursos cuya gestión tenga encomendada y para la imposición de sanciones, sin que puedan ser cedidos o comunicados a terceros, salvo en los supuestos previstos en las leyes.

j) Derecho a ser tratado con el debido respeto y consideración por el personal al servicio de la Administración tributaria.

k) Derecho a que las actuaciones de la Administración tributaria que requieran su intervención se lleven a cabo en la forma que le resulte menos gravosa, siempre que ello no perjudique el cumplimiento de sus obligaciones tributarias.

1) Derecho a formular alegaciones y a aportar documentos que serán tenidos en cuenta por los órganos competentes al redactar la correspondiente propuesta de resolución.

m) Derecho a ser oído en el trámite de audiencia, en los términos previstos en esta ley. 
n) Derecho a ser informado de los valores de los bienes inmuebles que vayan a ser objeto de adquisición o transmisión.

ñ) Derecho a ser informado, al inicio de las actuaciones de comprobación o inspección sobre la naturaleza y alcance de las mismas, así como de sus derechos y obligaciones en el curso de tales actuaciones y a que las mismas se desarrollen en los plazos previstos en esta ley.

o) Derecho al reconocimiento de los beneficios o regímenes fiscales que resulten aplicables.

p) Derecho a formular quejas y sugerencias en relación con el funcionamiento de la Administración tributaria.

q) Derecho a que las manifestaciones con relevancia tributaria de los obligados se recojan en las diligencias extendidas en los procedimientos tributarios.

r) Derecho de los obligados a presentar ante la Administración tributaria la documentación que estimen conveniente y que pueda ser relevante para la resolución del procedimiento tributario que se esté desarrollando.

s) Derecho a obtener copia a su costa de los documentos que integren el expediente administrativo en el trámite de puesta de manifiesto del mismo en los términos previstos en esta ley.

Este derecho podrá ejercitarse en cualquier momento en el procedimiento de apremio".

IV.1.Derechos y garantías de los contribuyentes en el desarrollo de los procedimientos tributarios.-Sin perjuicio de la enunciación que de los derechos de los obligados tributarios se hace en el artículo 34, el artículo 99 de la LGT menciona específicamente algunos derechos que pueden cobrar especial significado en la fase de desarrollo de los procedimientos tributarios. En efecto, el artículo 99 de la Ley 58/2003, de 17 de diciembre, General Tributaria, relativo al desarrollo de las actuaciones y procedimientos tributarios, establece lo siguiente:

"1. En el desarrollo de las actuaciones y procedimientos tributarios, la Administración facilitará en todo momento a los obligados tributarios el ejercicio de los derechos y el cumplimiento de sus obligaciones, en los términos previstos en los apartados siguientes.

2. Los obligados tributarios pueden rehusar la presentación de los documentos que no resulten exigibles por la normativa tributaria y de aquellos que hayan sido previamente presentados por ellos mismos y que se encuentren en poder de la Administración tributaria actuante. Se podrá, en todo caso, 
requerir al interesado la ratificación de datos específicos propios o de terceros, previamente aportados.

3. Los obligados tributarios tienen derecho a que se les expida certificación de las autoliquidaciones, declaraciones y comunicaciones que hayan presentado o de extremos concretos contenidos en las mismas.

4. El obligado que sea parte en una actuación o procedimiento tributario podrá obtener a su costa copia de los documentos que figuren en el expediente, salvo que afecten a intereses de terceros o a la intimidad de otras personas o que así lo disponga la normativa vigente. Las copias se facilitarán en el trámite de audiencia o, en defecto de éste, en el de alegaciones posterior a la propuesta de resolución.

5. El acceso a los registros y documentos que formen parte de un expediente concluido a la fecha de la solicitud y que obren en los archivos administrativos únicamente podrá ser solicitado por el obligado tributario que haya sido parte en el procedimiento tributario, sin perjuicio de lo dispuesto en el artículo 95 de esta ley.

6. Para la práctica de la prueba en los procedimientos tributarios no será necesaria la apertura de un período específico ni la comunicación previa de las actuaciones a los interesados.

7. Las actuaciones de la Administración tributaria en los procedimientos de aplicación de los tributos se documentarán en comunicaciones, diligencias, informes y otros documentos previstos en la normativa específica de cada procedimiento. Las comunicaciones son los documentos a través de los cuales la Administración notifica al obligado tributario el inicio del procedimiento $\mathrm{u}$ otros hechos o circunstancias relativos al mismo o efectúa los requerimientos que sean necesarios a cualquier persona o entidad.

Las comunicaciones podrán incorporarse al contenido de las diligencias que se extiendan. Las diligencias son los documentos públicos que se extienden para hacer constar hechos, así como las manifestaciones del obligado tributario o persona con la que se entiendan las actuaciones. Las diligencias no podrán contener propuestas de liquidaciones tributarias. Los órganos de la Administración tributaria emitirán, de oficio o a petición de terceros, los informes que sean preceptivos conforme al ordenamiento jurídico, los que soliciten otros órganos y servicios de las Administraciones públicas o los poderes legislativo y judicial, en los términos previstos por las leyes, y los que resulten necesarios para la aplicación de los tributos.

8. En los procedimientos tributarios se podrá prescindir del trámite de audiencia previo a la propuesta de resolución cuando se suscriban actas con acuerdo o cuando en las normas reguladoras del procedimiento esté previsto un trámite de alegaciones posterior a dicha propuesta. En este último caso, el expediente se pondrá de manifiesto en el trámite de alegaciones. 
El trámite de alegaciones no podrá tener una duración inferior a 10 días ni superior a 15 ".

IV.2.Derechos relativos a la información y asistencia a los obligados tributarios.- Se recogen en los artículos 85 a 91 de la LGT, siendo los siguientes:

a) Derecho a recibir información y asistencia. Así se extrae del artículo 85, que en su apartado primero dispone: "1.La Administración deberá prestar a los obligados tributarios la necesaria información y asistencia acerca de sus derechos y obligaciones".

La citada actividad se instrumentará, según dispone el apartado 2 del citado precepto, entre otras, a través de las siguientes actuaciones:

Publicación de textos actualizados de las normas tributarias, así como de la doctrina administrativa de mayor trascendencia ${ }^{12}$.

Comunicaciones y actuaciones de información efectuadas por los servicios destinados a tal efecto en los órganos de la Administración tributaria.

Contestaciones a consultas escritas.

Actuaciones previas de valoración.

Asistencia a los obligados en la realización de declaraciones, autoliquidaciones y comunicaciones tributarias.

b) Derecho a formular consultas tributarias escritas. Se regula en el artículo 88, según el cual:

“1. Los obligados podrán formular a la Administración tributaria consultas respecto al régimen, la clasificación o la calificación tributaria que en cada caso les corresponda.

2. Las consultas tributarias escritas se formularán antes de la finalización del plazo establecido para el ejercicio de los derechos, la presentación de declaraciones o autoliquidaciones o el cumplimiento de otras obligaciones tributarias.

La consulta se formulará mediante escrito dirigido al órgano competente para su contestación, con el contenido que se establezca reglamentariamente.

3. Asimismo, podrán formular consultas tributarias los colegios profesionales, cámaras oficiales, organizaciones patronales, sindicatos, asociaciones de consumidores, asociaciones o fundaciones que representen intereses de personas con discapacidad, asociaciones empresariales y organizaciones profesionales, así como a las federaciones que agrupen a los organismos o entidades antes mencionados, cuando se refieran a cuestiones que afecten a la generalidad de sus miembros o asociados.

12 Este deber que se impone a la Administración encuentra su reflejo en la página web del Ministerio de Hacienda y Administraciones Públicas: http:/www.minhap.gob.es/es-ES/Paginas/ Home.aspx y el siguiente enlace web: http://www.minhap.gob.es/es-ES/Normativa $\% 20 \mathrm{y} \% 20$ doctrina/Paginas/Normativa\%20y\%20doctrina.aspx (consultado el 17-11-2015). 
4. La Administración tributaria archivará, con notificación al interesado, las consultas que no reúnan los requisitos establecidos en virtud del apartado 2 de este artículo y no sean subsanadas a requerimiento de la Administración.

5. La competencia para contestar las consultas corresponderá a los órganos de la Administración tributaria que tengan atribuida la iniciativa para la elaboración de disposiciones en el orden tributario, su propuesta o interpretación.

6. La Administración tributaria competente deberá contestar por escrito las consultas que reúnan los requisitos establecidos en virtud del apartado 2 de este artículo en el plazo de seis meses desde su presentación.

La falta de contestación en dicho plazo no implicará la aceptación de los criterios expresados en el escrito de la consulta.

7. El procedimiento de tramitación y contestación de las consultas se desarrollará reglamentariamente.

8. La competencia, el procedimiento y los efectos de las contestaciones a las consultas relativas a la aplicación de la normativa aduanera comunitaria se regulará por lo dispuesto en el Código Aduanero Comunitario".

Por su parte, el artículo 89 regula los efectos de las contestaciones a las consultas tributarias escritas.

c) Derecho a recibir información del valor a efectos fiscales con carácter previo a la adquisición o transmisión de bienes inmuebles. Dispone el artículo 90 de la Ley General Tributaria:

"1. Cada Administración tributaria informará, a solicitud del interesado y en relación con los tributos cuya gestión le corresponda, sobre el valor a efectos fiscales de los bienes inmuebles que, situados en el territorio de su competencia, vayan a ser objeto de adquisición o transmisión.

2. Esta información tendrá efectos vinculantes durante un plazo de tres meses, contados desde la notificación al interesado, siempre que la solicitud se haya formulado con carácter previo a la finalización del plazo para presentar la correspondiente autoliquidación o declaración y se hayan proporcionado datos verdaderos y suficientes a la Administración tributaria.

Dicha información no impedirá la posterior comprobación administrativa de los elementos de hecho y circunstancias manifestados por el obligado tributario.

3. El interesado no podrá entablar recurso alguno contra la información comunicada. Podrá hacerlo contra el acto o actos administrativos que se dicten posteriormente en relación con dicha información.

La falta de contestación no implicará la aceptación del valor que, en su caso, se hubiera incluido en la solicitud del interesado". 
d) Derecho a solicitar la valoración a efectos fiscales de rentas, productos, bienes, gastos y demás elementos determinantes de la deuda tributaria (Acuerdos previos de valoración). Regulado en el artículo 91 de la LGT, según el cual: "1. Los obligados tributarios podrán solicitar a la Administración tributaria, cuando las Leyes o los reglamentos propios de cada tributo así lo prevean, que determine con carácter previo y vinculante la valoración a efectos fiscales de rentas, productos, bienes, gastos y demás elementos determinantes de la deuda tributaria.

2. La solicitud deberá presentarse por escrito, antes de la realización del hecho imponible o, en su caso, en los plazos que establezca la normativa de cada tributo.

A dicha solicitud se acompañará la propuesta de valoración formulada por el obligado tributario.

3. La Administración tributaria podrá comprobar los elementos de hecho y las circunstancias declaradas por el obligado tributario.

4. El acuerdo de la Administración tributaria se emitirá por escrito, con indicación de la valoración, del supuesto de hecho al que se refiere, del impuesto al que se aplica y de su carácter vinculante, de acuerdo con el procedimiento y en los plazos fijados en la normativa de cada tributo. La falta de contestación de la Administración tributaria en plazo implicará la aceptación de los valores propuestos por el obligado tributario.

5. En tanto no se modifique la legislación o varíen significativamente las circunstancias económicas que fundamentaron la valoración, la Administración tributaria que hubiera dictado el acuerdo estará obligada a aplicar los valores expresados en el mismo. Dicho acuerdo tendrá un plazo máximo de vigencia de tres años excepto que la normativa que lo establezca prevea otro distinto.

6. Los obligados tributarios no podrán interponer recurso alguno contra los acuerdos regulados en este precepto. Podrán hacerlo contra el acto o actos administrativos que se dicten posteriormente en aplicación de las valoraciones incluidas en el acuerdo".

En realidad, los acuerdos previos de valoración se introdujeron en el ordenamiento jurídico español en la ya derogada Ley 45/1995, de 28 de diciembre, del Impuesto sobre Sociedades, en cuyo artículo 16.6 se establecía la posibilidad de que la Administración tributaria y los contribuyentes pudieran llegar a acuerdos previos para la valoración de los precios de transferencia en las operaciones entre personas o entidades vinculadas. Con esta regulación se trataba de insertar en nuestro ordenamiento la técnica existente a partir de los años noventa en los Estados Unidos, conocida como APAs (advance pricing agreements), revelándose como el instrumento más adecuado para eliminar 
los riesgos que conlleva la aplicación de una estrategia incorrecta de precios de transferencia.

\section{IV.3.En el procedimiento de inspección de los tributos.-}

a) Derecho a que se hagan públicos los criterios que informen el Plan de Control Tributario: La Administración tributaria elaborará anualmente un Plan de Control Tributario que tendrá carácter reservado, aunque ello no impedirá que se hagan públicos los criterios generales que lo informen (art.116 LGT). Al respecto, para el año 2015 puede consultarse la Resolución de 9 de marzo de 2015, de la Dirección General de la Agencia Estatal de Administración Tributaria, por la que se aprueban las Directrices Generales del Plan Anual de Control Tributario y Aduanero para 2015 (publicadas en el Boletín Oficial del Estado de 11 de marzo de 2015 ${ }^{13}$ ).

b) Iniciación del procedimiento de inspección: Los obligados tributarios deben ser informados al inicio de las actuaciones del procedimiento de inspección sobre la naturaleza y alcance de las mismas, así como de sus derechos y obligaciones en el curso de tales actuaciones (Art.147.2 LGT).

c) Alcance de las actuaciones del procedimiento de inspección (art.148 LGT): Las actuaciones del procedimiento de inspección podrán tener carácter general o parcial (en este último supuesto, cuando no afecten a la totalidad de los elementos de la obligación tributaria en el período objeto de la comprobación $\mathrm{y}$ en todos aquellos supuestos que se señalen reglamentariamente).

d) Solicitud del obligado tributario de una inspección de carácter general (art.149 LGT): Todo obligado tributario que esté siendo objeto de unas actuaciones de inspección de carácter parcial podrá solicitar a la Administración tributaria que las mismas tengan carácter general respecto al tributo y, en su caso, períodos afectados, sin que tal solicitud interrumpa las actuaciones en curso.

El obligado tributario deberá formular la solicitud en el plazo de 15 días desde la notificación del inicio de las actuaciones inspectoras de carácter parcial.

La Administración tributaria deberá ampliar el alcance de las actuaciones o iniciar la inspección de carácter general en el plazo de seis meses desde la solicitud. El incumplimiento de este plazo determinará que las actuaciones inspectoras de carácter parcial no interrumpan el plazo de prescripción para comprobar e investigar el mismo tributo y período con carácter general.

e) Plazo de las actuaciones inspectoras (art.150 LGT). Las actuaciones del procedimiento de inspección deberán concluir en el plazo de 12 meses contado desde la fecha de notificación al obligado tributario del inicio del mismo. Se

13 https://www.boe.es/boe/dias/2015/03/11/pdfs/BOE-A-2015-2603.pdf (consultado el 17-11-2015) 
entenderá que las actuaciones finalizan en la fecha en que se notifique o se entienda notificado el acto administrativo resultante de las mismas.

No obstante, podrá ampliarse dicho plazo por otro período que no podrá exceder de 12 meses, cuando en las actuaciones concurra alguna de las siguientes circunstancias:

-Cuando revistan especial complejidad. Se entenderá que concurre esta circunstancia atendiendo al volumen de operaciones de la persona o entidad, la dispersión geográfica de sus actividades, su tributación en régimen de consolidación fiscal o en régimen de transparencia fiscal internacional y en aquellos otros supuestos establecidos reglamentariamente.

-Cuando en el transcurso de las mismas se descubra que el obligado tributario ha ocultado a la Administración tributaria alguna de las actividades empresariales o profesionales que realice.

Los acuerdos de ampliación del plazo legalmente previsto serán, en todo caso, motivados, con referencia a los hechos y fundamentos de derecho.

La interrupción injustificada del procedimiento inspector por no realizar actuación alguna durante más de seis meses por causas no imputables al obligado tributario o el incumplimiento del plazo de duración del procedimiento no determinará la caducidad del procedimiento, que continuará hasta su terminación, pero producirá los siguientes efectos respecto a las obligaciones tributarias pendientes de liquidar:

1) No se considerará interrumpida la prescripción como consecuencia de las actuaciones inspectoras desarrolladas hasta la interrupción injustificada o durante el plazo de los 12 meses.

En estos supuestos, se entenderá interrumpida la prescripción por la reanudación de actuaciones con conocimiento formal del interesado tras la interrupción injustificada o la realización de actuaciones con posterioridad a la finalización del plazo de 12 meses. En ambos supuestos, el obligado tributario tendrá derecho a ser informado sobre los conceptos y períodos que alcanzan las actuaciones que vayan a realizarse.

2) Los ingresos realizados desde el inicio del procedimiento hasta la reanudación de las actuaciones que hayan sido imputados por el obligado tributario al tributo y período objeto de las actuaciones inspectoras tendrán el carácter de espontáneos a los efectos de la aplicación del régimen de recargos por pago voluntario extemporáneo. Tendrán, asimismo, el carácter de espontáneos los ingresos realizados desde el inicio del procedimiento hasta la primera actuación practicada con posterioridad al incumplimiento del plazo de duración del procedimiento (12 meses) y que hayan sido imputados por el obligado tributario al tributo y período objeto de las actuaciones inspectoras. 
El incumplimiento del plazo de duración determinará que no se exijan intereses de demora desde que se produzca dicho incumplimiento hasta la finalización del procedimiento.

Cuando una resolución judicial o económico-administrativa ordene la retroacción de las actuaciones inspectoras, éstas deberán finalizar en el período que reste desde el momento al que se retrotraigan las actuaciones hasta la conclusión del plazo de 12 meses o en seis meses, si aquel período fuera inferior. El citado plazo se computará desde la recepción del expediente por el órgano competente para ejecutar la resolución. Esto mismo se aplicará a los procedimientos administrativos en los que, con posterioridad a la ampliación del plazo, se hubiese pasado el tanto de culpa a la jurisdicción competente o se hubiera remitido el expediente al Ministerio Fiscal y debieran continuar por la vía administrativa. En este caso, el citado plazo se computará desde la recepción de la resolución judicial o del expediente devuelto por el Ministerio Fiscal por el órgano competente que deba continuar el procedimiento.

IV.4.En el procedimiento sancionador tributario.- Estos derechos se regulan en los artículos 207 a 212 de la LGT:

a) Derecho de renuncia a la tramitación separada del procedimiento sancionador (art.208.1 LGT): El procedimiento sancionador en materia tributaria se tramitará de forma separada a los de aplicación de los tributos salvo renuncia del obligado tributario, en cuyo caso se tramitará conjuntamente. En este sentido, la Sentencia de la Audiencia Nacional de 2 de febrero de 2011 (JT\2011\95) establece que la Ley lo configura “como un 'derecho' del contribuyente en el elenco de los derechos que enumera, no como una 'obligación' de la Administración, es decir, que ejercido el derecho por el contribuyente a ser informado, se vulnera dicho derecho si la Administración hace caso omiso de la consecuencia derivada del ejercicio de ese derecho, el de ser informado. Quiere precisarse con ello, que la obligación de la Administración se hace depender del ejercicio del derecho, pues supone una respuesta a la pretensión de conocimiento de datos a la Administración (...)", añadiendo que la renuncia 'se configura como un 'derecho', cuyo ejercicio se somete al cauce procedimental reglamentario, haciéndose depender de la voluntad del contribuyente, al igual si pretende renunciar a la devolución que le correspondería como consecuencia de una autoliquidación; no es requisito procesal necesario el que por parte de la Administración se le vaya indicando las posibilidades de renuncia; se trata del ejercicio de un derecho, en el presente caso, procedimental que no resta de las garantías procesales, propias de un procedimiento sancionador, y que pueda elevarse a la categoría de motivo de nulidad de la resolución".

b) Conclusión del procedimiento sancionador en materia tributaria en el plazo máximo de seis meses contados desde la notificación de la 
comunicación de inicio del procedimiento (art.211.2 LGT): Se entenderá que el procedimiento concluye en la fecha en que se notifique el acto administrativo de resolución del mismo. El vencimiento de este plazo sin que se haya notificado resolución expresa producirá la caducidad del procedimiento. La declaración de caducidad podrá dictarse de oficio o a instancia del interesado y ordenará el archivo de las actuaciones. Dicha caducidad impedirá la iniciación de un nuevo procedimiento sancionador.

c) Recursos contra sanciones (art.212 LGT): Se podrá recurrir la sanción sin perder la reducción por conformidad prevista en la Ley (párrafo b del apartado 1 del artículo 188) siempre que no se impugne la regularización.

La interposición en tiempo y forma de un recurso o reclamación administrativa contra una sanción producirá los siguientes efectos:

1. La ejecución de las sanciones quedará automáticamente suspendida en período voluntario sin necesidad de aportar garantías hasta que sean firmes en vía administrativa.

2. No se exigirán intereses de demora por el tiempo que transcurra hasta la finalización del plazo de pago en período voluntario abierto por la notificación de la resolución que ponga fin a la vía administrativa. 


\section{REFERENCIAS}

Alonso Murillo, F.: “Comentario al artículo 1", en Alonso Murillo, F., Blaso Delgado, C., Gómez Cabrera, C, y López Martínez, J.: Comentarios a la Ley de Derechos y Garantías de los Contribuyentes, Ed. Mc.Graw-Hill, Madrid, 1998

Carrasco Parrila, P.J.: Consecuencias del retraso en el pago de las deudas tributarias, Ed. Servicio de Publicaciones de la Universidad de Castilla-La Mancha, Cuenca 2000.

Carrasco Parrilla, P.J.: "Comentarios a la Ley 1/1998, de Derechos y Garantías de los Contribuyentes”, La Ley, Revista Jurídica española de doctrina, jurisprudencia y bibliografía, $n^{\circ} 1,1991$.

Ferreiro Lapatza, J.J.: "El Estatuto del Contribuyente", Civitas, REDF, nº88, 1995.

Palao Taboada, C.: "Lo «blando» y lo «duro» del Proyecto de Ley de Derechos y Garantías de los Contribuyentes”, Rev. Estudios Financieros, $\mathrm{n}^{\mathrm{o}} 171,1997$.

Parejo Alonso, L.: “Objeto, ámbito de aplicación y principios generales de la Ley de Régimen Jurídico de las Administraciones Públicas y del Procedimiento Administrativo Común”, en Leguina Villa, J., y Sánchez Morón, M. (dirs.): La nueva Ley de Régimen Jurídico de las Administraciones Públicas y del Procedimiento Administrativo Común, Ed.Tecnos, Madrid, 1993. 



\section{EI alcance de la actio in rem verso en las normas de contratos del sector público. Especial referencia al enriquecimiento injusto o sin causa de la administración en materia de contratos}

Jesús Punzón Moraleda*

Resumen: Acción de reembolso o de resarcimiento que podría tener lugar en la actualidad solamente en aquellos supuestos en los que el Ordenamiento jurídico no satisfaga los desequilibrios patrimoniales no justificados, convirtiéndose en una regla que en referencia a los contratos públicos sólo puede tener una operatividad restringida o supletoria.

Palabras clave: acción in rem verso, contratos públicos, principios de la contratación pública.

Abstract: Action of reimbursement which is operative in those cases where the law does not meet the unjustified economic imbalances. It is, therefore, an action that has a restricted operation of TRLCSP.

Key words: action in rem verso, public procurement, principles of public procurement.

* Prof. CD-Derecho administrativo, Universidad de Castilla-La Mancha 


\section{Introducción}

La actio in rem verso ${ }^{1}$ es una locución latina por la cual identificamos una regla o máxima jurídica que literalmente podría traducirse como "acción de lo invertido en la cosa" y que trata de definir una "acción de reembolso o de resarcimiento" que podría tener lugar en la actualidad solamente en aquellos supuestos en los que el ordenamiento jurídico no satisfaga los desequilibrios patrimoniales no justificados, convirtiéndose en una regla que, a nuestro juicio, y en referencia a los contratos públicos, sólo puede tener una operatividad restringida o supletoria -término tal vez más adecuado que subsidiario, utilizado por parte de la doctrina e incluso en alguna concreta legislación, puesto que sólo el concepto de supletoriedad permitiría que se pudiera acudir a esta acción si no existiese una acción principal ${ }^{3}$ en un cuerpo

1 No hay mucha bibliografía específica dedicada al estudio de esta acción, pero valga como ilustrativa la siguiente: Barrientos Grandon, Javier, "La acción de "in rem verso" en la literatura jurídica francesa: de Pothier a 'L'Arrêt Boudier'”, Revista de Historia del Derecho Privado, núm. 3, 2000, págs. 43-148; Dagorne-Labbe, Yannick, "Retour à une conception traditionnelle et extensive de l'exception de subsidiarité de l'action de in rem verso", Semaine juridique, núm. 39, 2009, págs. 13-14; H. Perinet-Marquet, "Le sort de l'action de in rem verso en cas de faute de l'appauvri", Semaine juridique, 1982, I, 3075; M. Lecene-Marenaud, "Le róle de la faute dans les quasicontrats", Revue trimestrelle de droit civil, 1994, pp. 5515 y ss; y por supuesto, la obra de Rebollo Puig, Manuel, El enriquecimiento injusto de la Administración Pública, Ed. Marcial Pons, Madrid, 1995, especialmente págs. 10 y ss. -“4. Acción y principio general de enriquecimiento injusto. El enriquecimiento injusto como fuente de obligaciones. Condictio o actio de in rem verso"-; De Vicente González, José Luis, "Enriquecimiento injusto y prestación no contratada en el ámbito de la administración local”, RAP, núm. 168, sep-dic, 2005, págs. 409 y ss.

${ }^{2}$ En realidad, a nuestro juicio, lo que en un momento debió de ocurrir es confundir la actio in rem verso con la actio in rem verso utilis, la cual, en opinión de Alfonso Oramas Gross, “....esta es una acción pretoria de equidad para el caso de que alguien se hubiera enriquecido por efecto de un contrato celebrado entre dos personas sui iuris, o sea, en el caso de un enriquecimiento indirecto." De todas formas, la tradición doctrinal y jurisprudencial se ha reconducido con el tiempo a que los "tratamientos" jurídicos derivados "sin justa causa" deriven en la denominación que ahora estudiamos.

Entre nuestra doctrina temporal y material más próxima, Rebollo Puig, El enriquecimiento..., Op. cit. pág. 11, precisamente hace alusión al tema de la diversidad semántica a la hora de concretar la acción, exponiendo diversas concepciones que han siendo asimiladas conforme ha evolucionando la ciencia jurídica. De esta forma expone, por ejemplo, las siguientes variaciones: condictio, o de condictio sine causa generalis, o se concreta, según los casos, una de las manifestaciones específicas sobre las que se quiere reforzar su proximidad (condictio indebiti, causa data causa non secuta, ob turpem vel iniustam causam...).

3 A nuestro juicio, aunque tal alcance no hemos podido contrastarlo con la doctrina que ha trabajado el tema que tratamos, tampoco estaría justificada la utilización de la actio in rem verso en aquellos supuestos en los que la acción normativa que posee el contratista hubiese decaído, como por ejemplo ocurriría en aquellos supuestos en los que pudiera aplicarse la extemporaneidad de una acción que bien pudiéramos denominar principal o preferente. Resulta evidente que no se trata de una "acción comodín" respecto de la cual el contratista pudiera hacer uso a su antojo obviando los procedimientos contractuales y sin utilizar las armas procedimentales que le ofrece la legislación en curso. De admitirse una solución distinta a la que nosotros proponemos sería 
legislativo específico, como por ejemplo, el de los contratos públicos, - del actual TRLCSP.

El estudio y la aceptación jurídica de la actio in rem verso aparece lejano en el tiempo, ligados básicamente a escritos vinculados a la rama civilística. Así, Gómez de la Serna, en 1848, ${ }^{4}$ define esta acción como aquella "...fundada en el principio de equidad de que nadie debe enriquecerse con perjuicio de otro".

Intentando buscar su origen, por cierto, romano, aunque indefinido, encontramos abundante bibliografía entre la que el libro de Iglesias Redondo ${ }^{6}$ se presenta como relevante porque trae a colación un texto de Ulpiano: "Et regulariter dicimus totiens de in rem verso esse actionem, quibus casibus procurator mandati vel qui negotia gessit negotiorum gestorum haberet actionem quotiensque aliquid consumpsit servus, ut aut meliorem rem dominus habuerit aut non deteriorem”. (D. 15,3,3,2, Ulp. 29 ad ed.) ${ }^{7}$.

Por otra parte, releyendo una obra que bien podríamos considerar ya un clásico del Derecho administrativo español contemporáneo, nos estamos refiriendo a la obra de Rebollo Puig El enriquecimiento injusto de la Administración Pública ${ }^{8}$, encontramos en el prólogo - de una fuerza jurídica inusual por su plasticidad y magnifico encuadre expositivo-, redactado por el profesor Frank Moderne, un texto que bien puede servirnos como marco de este humilde estudio sobre la actio in rem verso:

"El análisis de las relaciones establecidas entre el enriquecimiento injusto y el contrato administrativo resulta particularmente esclarecedor y permite marcar mejor la diferencia de enfoque del Derecho español y del Derecho francés. Este último, como ya se ha dicho, se esfuerza en restringir la fuerza expansiva de la noción de enriquecimiento sin causa y en limitar su utilización a algunas hipótesis

claramente actuar "contra legem", es decir, contra las prescripciones, por ejemplo, temporales, que la LCSP establece para los supuestos específicos de la declaración de nulidad y sus efectos, de donde podemos deducir, sin temor a equivocarnos, que en la actualidad no está permitida por nuestro ordenamiento jurídico una acción, independiente de su denominación, que desvirtúe con su autonomía procesal la articulación propia contractual.

${ }^{4}$ Gómez de la Serna, Pedro, Tratado académico-forense de procedimientos judiciales, Volumen 1, Ed. Librería de Ángel Calleja, 1848, pág. 182.

5 Además de indefinido, siempre tuvo una vertiente civil, puesto que fue concebida para que los patres familias respondieran, bajo ciertas condiciones, por las obligaciones contraídas por incapaces que se encontraban bajo su tutela.

${ }^{6}$ Iglesias-Redondo, Juan, Repertorio bilingüe de definiciones, reglas y máximas jurídicas romanas, Ed. Cívitas, $1^{a}$ ed., Madrid, 1986, pág. 24.

7 Según traducción del propio autor: "Comúnmente decimos que se da acción de provecho obtenido siempre que un procurador tuviere la de mandato, o el gestor la de gestión de negocios, y cuando el esclavo gastó algo para mejorar o impedir el deterioro del patrimonio del dueño".

Por otro lado, Nelson Nicoliello (Diccionario del latín jurídico, Ed. Bosch, Barecelona, 1999, pág. 10), afirma de la actio in rem verso que se trata de la "Acción de vuelta por la cosa: por enriquecimiento sin causa."

${ }^{8}$ Rebollo Puig, Manuel, El enriquecimiento..., Op. cit. 
relativamente marginales y globalmente ligadas a los cuasi-contratos. Es decir, insiste en el carácter «subsidiario» de la acción de in rem verso. Tomado al pie de la letra, el término es sin duda desafortunado y poco expresivo. Sin embargo, en los sistemas jurídicos que lo aceptan sirve para impedir que se llegue a una utilización descabellada o poco razonable de la acción de restitución y para contener su extensión virtual, en detrimento de otros cauces más adecuados al objeto de la demanda y con un armazón jurídico más sólido. En suma, se trata de una idea simple: la acción de enriquecimiento sin causa exige que se hayan agotado previamente las otras posibilidades de obtener justicia."

\section{Antecedentes jurisprudenciales en materia de contratación administrativa}

Recordando la máxima de Ulpiano iuris prudentia est divinorum atque humanorun iniusti scentiae (D. 1,1,10,2, Ulp. 1 reg), vamos a exponer algunas sentencias del orden jurisdiccional Contencioso-Administrativo que sirvan, a modo de registro histórico, para comprobar la aplicación de la actio in rem verso en materia de contratación.

Así, por ejemplo, en la Sentencia del Tribunal Supremo (Sala de lo Contencioso-Administrativo) de 29 de octubre de $1980^{10}$ se sostiene que si el Juez Contencioso-Administrativo anula el contrato, las obras recibidas por la Administración quedarían en su poder sin compensación alguna para el contratista. Por tanto, en supuestos de este tipo, en vez de aplicar las cláusulas del contrato se aplica el principio derivado del enriquecimiento injusto o sin causa.

\footnotetext{
${ }^{9}$ Rebollo Puig, Manuel, El enriquecimiento..., Op. cit. pág. XV.

${ }^{10}$ Considerando Segundo: "Que lo anterior revela cómo lo verdaderamente cuestionado sería la legitimidad de un acto (el denegatorio de esa petición de pago) y sus consecuencias, estimatorias o no, de la pretensión de abono de esas sumas, y por eso no podrá reputarse ajustada a derecho la sentencia apelada en cuanto al pronunciar la nulidad del contrato, deja estas pretensiones sin resolver, como si solamente hubiera de poder fundarse la exigencia del pago de las obras en las obligaciones directamente derivadas del contrato, cuando es obvio que éste estaba ya ejecutado por el contratista, quien había hecho entrega de las obras y éstas recibidas provisionalmente por el Ayuntamiento, discutiéndose solamente el importe de las mismas, parte de él reconocido, y los daños y perjuicios; supuesto que, incluso en casos donde la causa de invalidez pudo ser la misma que aquí (...) ha dado solución la doctrina de esta Sala mediante la aplicación, no de las cláusulas del contrato ni por tanto de las obligaciones de ellas derivadas, sino de los principios generales en cuanto, entregada la obra e ingresada la misma en el patrimonio municipal, incluso usada ya como en este caso, la simple invalidación abocaría a consecuencias de injusticia, lesivas además para la parte a quien no era imputable la causa de la nulidad; por eso en tales supuestos se ha venido fundando la obligación municipal de abonar el precio de la obra al contratista en el enriquecimiento injusto o el cuasi contrato de gestión de negocios de la Administración y el ejercicio de una «actio in rem verso» determinantes de la obligación del pago en cuanto la obra ejecutada quedó en su poder; de aquí la procedencia de, revocando la sentencia de 1. ' Instancia, declararlo así con las consecuencias que siguen.”
} 
Otra Sentencia de interés es la Sentencia del Tribunal Supremo (Sala de lo Contencioso-Administrativo, Sección $5^{\mathrm{a}}$ ) de 12 de marzo de $1991^{11}$ y ${ }^{12}$. En ella se sopesa el rigor formal del contrato (art. 54 RCCL) con el desequilibrio económico que se produciría de no obviarse tal circunstancia para el caso concreto, aplicando la actio in rem verso y apoyándose en gran medida en su aplicación constante en el tiempo por la doctrina civilística.

\footnotetext{
${ }^{11}$ En sentido similar puede consultarse la Sentencia de Tribunal Supremo (Sala de lo ContenciosoAdministrativo) de 20 de octubre de $1987\left(\mathrm{FJ} \mathrm{5}^{\circ}\right)$.

${ }^{12}$ FJ 30: "Que, formulada por el contratista reiteradamente la petición de abono del importe, excedente del presupuesto, correspondiente a las obras complementarias, con verdadera conexión o por extensión con las proyectadas, y en cuanto a la liquidación de su importe, apreciada la realidad de estas obras reclamadas, así como su valoración total, si bien es cierto que el art. 51 del Reglamento de Contratación de las Corporaciones Locales proclama la inalterabilidad contractual, también es cierto que la Jurisprudencia ha venido suavizando la aplicación de tal principio, a través de una interpretación flexibilizadora de los arts. 53 y 54 del precitado Reglamento, y aun reconociéndose que lo más correcto jurídicamente hubiere sido el cumplimiento, en su momento, de las formalidades previstas en el art. 54 del propio Reglamento de contratación, sin embargo, su omisión no puede privar al contratista, que realizadas las obras, del derecho a que se le abone, por el Ayuntamiento el importe de las mismas, pues si ellas lo fueron en las circunstancias indicadas y, por lo tanto, contribuyendo a complementar el Proyecto y suplir sus deficiencias imprevisiones es claro que como dice la Sentencia del Tribunal Supremo de 20 de diciembre de 1983, resolviendo un caso semejante al presente, por un principio de Derecho no se puede consentir la consumación de un desequilibrio económico entre los beneficios obtenidos con la realización de tales obras y las cargas sufridas con su ejecución, y la aplicación de tal principio que veda un enriquecimiento injusto posibilita el reconocimiento en los contratos de obras, de las reclamaciones por los excesos sobre el Proyecto que hubieren sido efectivamente ejecutados de conformidad con el Ingeniero Director, solución a la que también se llega, en definitiva, a través de otra instrumentación jurídica, en $\mathrm{S}$. de 22 de enero de 1975, resolviendo un supuesto, asimismo, similar al presente; y es que como hacen notar las sentencias de 22 de junio de 1982, de 12 de junio de 1984 y 20 de octubre de 1987, la legitimación de esta clase de pretensiones reclamatorias del importe de las obras realizadas pero no comprendidas expresamente en el presupuesto, si bien no se puede corregir a través de la técnica de la «negotiorum gestio» por existir una relación contractual se debe solventar aplicando la regla que prohíbe el enriquecimiento sin causa que ya en el derecho histórico dio lugar a que se le considerara origen de una de las figuras del cuasicontrato; apareciendo en el «Corpus iuris» en el que actuaba como base y medida de la responsabilidad origen de una «condictio» que posibilitaba la reclamación reparadora; institución ésta del enriquecimiento sin causa que, como es sabido, pasó a nuestro derecho a través de las «Partidas» (Partida 7. ${ }^{\text {, }}$ Libro XVII, Título 34) y que aunque no fue recogida por nuestro Código Civil por su supeditación al Código Napoleónico, ello no ha impedido la elaboración de una doctrina jurisprudencial constante y uniforme de la que son ejemplo las Sentencias citadas más arriba y con carácter más general las más antiguas de 2 de mayo de 1960, 12 de mayo de 1964, 16 de marzo de 1965, 4 de junio de 1966, 26 de marzo de 1968, 18 de marzo de 1972 y 22 de enero de 1975 entre otras; habiéndose articulado procesalmente este principio desde la época romana mediante el ejercicio de la «actio in rem verso» como señala la ya citada Sentencia de 22 de junio de 1982; y como dice la de 12 de junio de 1984, con cita del art. 7.1 del Código Civil y de reiterada jurisprudencia, el principio de la buena fe viene a reforzar también el derecho a formular esta reclamación, pues no se puede concebir en un Estado de Derecho inspirado en la justicia, que unas obras como las de autos, efectuadas por el contratista en las circunstancias narradas y por expresa indicación de su Dirección Facultativa pudieran quedar sin la correspondiente compensación."
} 


\title{
III. Dictámenes básicos en defensa de la acción in rem verso
}

\author{
El primer Dictamen que debemos citar es el Dictamen del Consejo de Estado \\ de 14 de marzo de $1996^{13}$. En él se determina respecto a una subcontratación \\ que no siguió los cauces formales legales (art. 59 LCE) que consiste en
}

13 "V. Se ha indicado anteriormente que procede el pago a los subcontratistas de la cantidad reclamada que se corresponde a la obra realmente ejecutada. Tal pago no procede por virtud del contrato, ya que, como ha quedado reflejado en antecedentes, esa subcontratación carece de validez jurídico administrativa al no haber sido conocida, en la forma prevenida por la Ley, por parte de la Administración municipal.

En el Derecho español, si se tratara de subcontratistas, dispondrían de la acción directa (artículo 1597 del Código Civil) o de la subrogatoria general (artículo 1111 del Código Civil y 182 párrafo segundo del Reglamento de Contratación del Estado. Pero no lo son formalmente, al no haberse cumplido los requisitos del artículo 59 de la Ley de Contratos del Estado. Para tal caso, el ordenamiento civil previene como regla general la posible actio in rem verso que autoriza el artículo 1893.1 del Código Civil (Sentencia del Tribunal Supremo, Sala Primera, de 6 de noviembre de 1985). En el Ordenamiento jurídico administrativo se obtiene ese efecto por aplicación del principio de prohibición del enriquecimiento injusto.

Este principio ha venido siendo aplicado por la jurisprudencia del Tribunal Supremo (Sentencias, entre otras, de 20 de enero de 1971 y 11 de octubre de 1979), en los casos en que la realización de una obra sin vínculo contractual beneficia a la Administración a favor del particular que la hizo, a modo de cuasicontrato administrativo. Además, este principio, con el de la exigencia de buena fe en la actuación administrativa, ha sido igualmente aplicado para corregir los efectos de desequilibrio patrimonial que pueden resultar (en casos similares al presente) de la estricta aplicación de las reglas de nulidad contractual: Sentencias del Tribunal Supremo de 21 de abril de 1976, y 12 de junio de 1984.

Así pues, producida la nulidad del contrato, el Ayuntamiento se beneficia de la obra realizada por terceros, no unidos al mismo por vínculo contractual. El principio de prohibición de enriquecimiento injusto funda la obligación de pago del trabajo ejecutado y realmente aprovechado por la Corporación local.

Por ello, al liquidar el contrato se deberá determinar la obra ejecutada, su valor, y en esa cuantía abonar a los "subcontratistas" (que formalmente no lo son) el importe de lo reclamado en la proporción que resulte. Ha de tenerse en cuenta que la regla de prohibición del enriquecimiento injusto permite pagar al "subcontratista" sólo hasta el límite de su empobrecimiento. En este caso parece apreciarse que uno es el valor de la obra (que resulta de su presupuesto), y otro inferior el valor de lo ejecutado por los subcontratistas (que se corresponderá al precio que convinieron con la contrata). Así pues, el Ayuntamiento, a cargo del crédito presupuestado, deberá resarcir a los subcontratistas hasta el límite de su reclamación (que parece inferior al valor presupuestado). Una vez efectuado dicho pago, aún habrá un enriquecimiento a favor del Ayuntamiento, sin causa. Tal es el sobrante que habrá de aplicarse al pago a prorrata de sus créditos de los Bancos endosatarios, una vez liquidada la indemnización de daños y perjuicios.

En efecto, habrá de liquidarse daños y perjuicios a reclamar contra la contrata. Para ello habrá de determinarse la parte de obra ejecutada que lo haya sido directa y realmente por la contrata, y aplicarse el importe de su valor al pago de esos daños y perjuicios en primer lugar y sólo el sobrante, si lo hubiere, a lo reclamado por los Bancos endosatarios, junto con la cantidad antes indicada.

Por lo expuesto, el Consejo de Estado, por mayoría, es de dictamen:

«Que procede la revisión de oficio del acto de adjudicación del contrato objeto de esta consulta a así como la declaración de nulidad de dicho contrato, y en consecuencia la liquidación del mismo como se indica en el cuerpo de este dictamen»." 
ejecutar la actio in rem verso en aplicación del principio de prohibición de enriquecimiento injusto de la Administración. Por tanto, con la actio al servicio del "subcontratista", se corrigió la realización de una obra sin vínculo contractual y al amparo del principio de buena fe del "subcontratista" para poder corregir los efectos del desequilibrio patrimonial que, de no aplicarse, se produciría.

Resulta interesante que para calcular el valor que la Administración tiene que abonar a los "subcontratistas", que en todo caso, se debe evaluar, a nuestro juicio, con una interpretación correcta de la acción in rem verso, "sólo hasta el límite de su empobrecimiento", es decir, el valor de lo ejecutado por los "subcontratistas", no el valor de la obra resultante del presupuesto.

Otro Dictamen relevante es el del Consejo de Estado núm. 828/2003, de 29 de mayo de $2003^{14}$. En este Dictamen se valoró una modificación en el

14 “4. Respecto al fondo del asunto, es de resaltar que se trata de abonar unos trabajos adicionales, no contemplados en el proyecto inicial, y que fueron ejecutados por la empresa adjudicataria.

EI Consejo de Estado debe señalar en primer término la irregularidad que comporta la ejecución de trabajos, sin haberse aprobado el oportuno proyecto reformado y, por tanto, contraviniendo el procedimiento legalmente establecido. Dicha actuación comporta una infracción de lo prevenido en la legislación de contratos del Estado que, de forma tajante, establece que ni la Administración, ni el contratista, ni ambos de consuno, pueden introducir o ejecutar modificaciones en la obra objeto de contrato sin la debida aprobación. Ello aunque, los trabajos adicionales ejecutados se pretendan basar en una mayor agilidad y eficacia en la gestión del interés público. Lo pertinente, pues, hubiere sido aprobar la correspondiente modificación contractual. Y ello, por cuanto el procedimiento de aprobación de un proyecto modificado tiene por objeto valorar la pertinencia legal y la oportunidad de las variaciones a introducir en los trabajos inicialmente adjudicados en atención al interés público, a la disciplina presupuestaria y a las reglas rectoras de la contratación pública; en especial, a los principios de publicidad y concurrencia que aseguran los derechos de eventuales licitadores y de la propia Administración.

5. No obstante lo expresado, el Consejo de Estado considera que procede someter, en su caso, a la consideración del Consejo de Ministros la convalidación del gasto, por importe de $15.903,31$ euros (2.646.088 pesetas) y sin que se hubiere aprobado el correspondiente proyecto reformado. Y es que dicha convalidación del gasto hecho requiere la decisión final del Consejo de Ministros, de conformidad con lo establecido en el artículo 32 del Real Decreto 2188/1995, de 28 de diciembre de 1995.

La oportunidad y conveniencia de los trabajos efectuados, aun cuando no pueden ser valoradas por este Consejo al no existir datos en el expediente que permitan hacerlo, aparecen avaladas, bajo su exclusiva garantía técnica, por los servicios del Ministerio de Fomento, quien además los ha reconocido y recibido.

6. Consta, por último, que existen recursos financieros suficientes para afrontar el pago de la cantidad propuesta, según informe del Servicio Instructor.

Así las cosas, es claro que resulta procedente abonar a la empresa contratista los trabajos ejecutados, pues, de otro modo, se produciría un enriquecimiento injusto de la Administración. Por ello, debe quedar a salvo el eventual derecho del contratista a que se le liquiden los trabajos ejecutados y recibidos, pues, como ha señalado la jurisprudencia, "incluso en la hipótesis de que la realización de una obra o servicio por un particular en beneficio de la Administración no cuente con base paccionada por elemental que sea... lo procedente, ante la situación fáctica irreversible y los intereses subyacentes, es configurar esta situación 
contrato sin seguir los cauces formales establecidos al efecto. El Consejo de Estado se decantó por someter al Consejo de Ministros la convalidación del gasto, aun a falta de las formalidades indicadas, en virtud de que, de no hacerlo, se produciría un enriquecimiento injusto de la Administración motivado por una situación fáctica irreversible, de donde se deriva que el cuasi contratista dispone de una actio in rem verso para poder remediar dicha situación.

\section{Apuntes doctrinales en cuanto a la aceptación de la acción in rem verso}

Teniendo en cuenta los antecedentes expuestos, hay que declarar que la doctrina no se ha manifestado unánime a la hora de aceptar sin reparos la actio in rem verso.

Ya Villar Palasí15, refiriéndose a los "efectos de la declaración de nulidad radical de los contratos", afirmaba que si un contrato había tenido una existencia de hecho, al menos como supuesto de hecho con cierta apariencia de validez, mientras no sea declarado nulo, puede producir efectos. Pues bien, uno de estos efectos es precisamente el que se pueda producir una mutua compensación o indemnización por los trabajos o por los gastos realizados, $y$ que supongan un beneficio para una de las partes (art. 29 del RCE). De esta forma, concluía el citado autor, el contratista podrá ejercitar una actio in rem verso fundada en el enriquecimiento injusto por aquellas obras o servicios ejecutados que, una vez declarada la nulidad, quedan en beneficio de la administración ${ }^{16}$.

Resulta evidente que el fundamento de fondo consiste en una relación cuasi contractual en la que normalmente el perjudicado resulta ser el contratista y que como consecuencia está en su derecho en que al menos se le reembolsen los gastos realizados, puesto que a la Administración le están o le pueden generar un beneficio las aportaciones realizadas por el contratista; se trataría, en resumen, de un resarcimiento al gestor de buena fe fundado en un enriquecimiento "sin causa", injusto, por parte de la Administración.

Por otra parte, en materia de subcontratación y aplicándose el Real Decreto Legislativo 2/2000, Serrera Contreras ${ }^{17}$ argüía que no era posible aplicar la

como cuasicontrato de gestión de negocios ajenos (negotiorum gestio) en virtud de la cual la Administración debe compensar al cuasicontratista ... disponiendo éste de una actio in rem verso en el enriquecimiento sin causa..." (Sentencia del Tribunal Supremo de 11 de octubre de 1979)."

15 Villar Palasi, Lecciones sobre contratación administrativa, Madrid, 1969, pág. 254.

16 Garrido Falla, Fernando, Tratado de Derecho administrativo, Tomo II, Ed. Instituto de Estudios Políticos, 1966, pág. 81.

17 Serrera Contreras, Pedro Luis, "Algunas cuestiones sobre responsabilidad en el contrato de concesión de obra pública”, Revista Andaluza de Administración Pública, núm. 52, oct-nov-dic, 2003. 
actio in rem verso en los contratos administrativos, básicamente porque según el citado autor la LCAP regulaba de forma detallada los requisitos que habían de darse para que entrara en juego la figura de la subcontratación (art. 115 LCAP), así como la forma y condiciones de los pagos que el contratista había de hacer a los suministradores (art. 116 LCAP).

En opinión de Díaz Delgado ${ }^{18}$, puesto que en la mayoría de los supuestos de nulidad no se puede restituir in natura, y en el supuesto de que sea la Administración la culpable de la nulidad acaecida, lo lógico es que se proceda a una indemnización por los daños y perjuicios al contratista. El citado autor hace mención al artículo $1256 \mathrm{CC}^{19} \mathrm{y}$ tomando parte en la discusión doctrinal que hubo al respecto, se decanta por la tesis mantenida por Garrido Falla - que no era partidario de la posibilidad de decisión unilateral a cargo de la Administración-, frente a la argumentación de García de Enterría - que no veía obstáculo en que la Administración pudiera decidir de forma unilateral-, que es la tesis que, con matices, finalmente ha prevalecido en "base a la inclusión de la cláusula de decisión unilateral y ejecutoria y a la exigencia de acto previo para recurrir el contratista".

Por otra parte, Alonso Higuera ${ }^{20}$ trae a colación los principios de buena fe y confianza legítima ${ }^{21}$ contenidos en el artículo 3.1 de la LRJPAC, para fortalecer su opinión respecto a una línea basada en la preocupación porque la Administración no quede ajena al cumplimiento de una relación cuasicontractual por las irregularidades que pudieran derivar en la nulidad radical del contrato en el curso del procedimiento administrativo de contratación, y esto en tanto en el supuesto de que la acción se pueda fundar en un cuasicontrato de servicios ajenos ${ }^{22}$ como si se trata de un enriquecimiento injusto

\footnotetext{
18 Díaz Delgado, José, “Comentarios al art. 65, Efectos de la declaración de nulidad”, en AA.VV., Comentarios a la Ley de contratos de las Administraciones Públicas y a la Ley sobre procedimientos de contratación de los sectores especiales, Dir. Ricardo García Macho, Ed. Tirant lo Blanch, Valencia, 2003, pág. 363.

19 Determina dicho artículo: "La validez y el cumplimiento de los contratos no puede dejarse a disposición de uno de los contratantes".

20 Alonso Higuera, Carmen, "Ley de contratos del sector público: ámbito de aplicación. Modalidades contractuales y régimen de invalidez de los procedimientos de contratación", en Estudios sobre la Ley de contratos del sector público, Coord. Jesús Colás Tenas y Manuel Medina Guerrero, Ed. Fundación Democracia y Gobierno Local-Institución Fernando El Católico, Madrid, 2009, págs. 100 y 101.

${ }^{21}$ Citando en nota a pie de pág. 63 la STS de 23 de abril de 1996, recogida en la STSJ de La Rioja de 25 de mayo de 2000.

${ }^{22}$ Conforme a una variada jurisprudencia del TS (STS de 23 de abril de 1996, que a su vez destaca, con arreglo a precedente doctrina jurisprudencial de la Sala Tercera del Tribunal Supremo, contenida en las SSTS de 1 de febrero de 1982, 13 de julio de 1984 y 25 de septiembre de 1985: sobre esta sentencia puede consultarse un breve comentario de Ballesteros Fernández (Ballesteros Fernández, Ángel, Manual de Administración Local, Biblioteca Comares de ciencia jurídica, Ed. El Consultor de los Ayuntamientos y Juzgados, Madrid, 2006, pág. 475) contenida en la obra Coord. por Jiménez Aparicio -AA.VV., "Comentario al artículo 25", en Comentarios a la Legislación de Contratación Pública, Coord. Emilio Jiménez Aparicio, Tomo I, Ley 30/2007,
} 
por parte de la Administración.

El profesor Rebollo Puig ha mantenido con elocuencia ${ }^{23}$ que la actio in rem verso tiene una serie de características propias: a) Es una acción personal de restitución de valor frente al enriquecido injustamente o sin causa -no una acción real que permita recuperar la cosa o deshacer la atribución patrimonial operada-; b) No es tampoco una acción erga omnes contra cualquiera que finalmente haya ingresado en su patrimonio la cosa, sino precisamente frente al enriquecido; c) Se trataría de una acción basada en el principio general que tiene como base sustentar la acción a falta de una regulación positiva del enriquecimiento injusto -sería una fuente de obligaciones que se hacen efectivas a través de la acción-; y d) El enriquecimiento injusto, base de la acción, parte de un desequilibrio, patrimonial que sería definitivo y real si no fuera por el derecho y la obligación restitutoria que él mismo crea.

\section{La "forma" en el contrato administrativo como presupuesto de discusión}

La doctrina administrativista ha recaído siempre en el elemento "formal" como un aspecto singular y diferenciador en materia contractual, sobre todo si el análisis se centra en su comparación con los contratos civiles. Así, por ejemplo, González-Berenguer" ${ }^{24}$ indicaba que "...la observancia de la forma hace referencia desde la necesidad de atenerse rigurosamente a lo prescrito en cada caso para contratar (...), hasta la necesidad de observar un modus operandi específico y muy circunstancialmente establecido, para la designación de la persona con quien se contrata". En la misma línea, Villar Palasí se expresa definiendo al derecho administrativo como formalista, y concretamente en materia de contratos, también la LCE estaba orientada en tal sentido.

Pero no hay que retrotraerse excesivamente en el tiempo para descubrir que la formalidad contractual ha sido siempre la voluntad del legislador en materia de contratos administrativos.

de 30 de octubre de Contratos del Sector Público (Arts. 1 a 92), Ed. Aranzadi, $3^{\text {a }}$ ed., Cizur Menor (Navarra), 2009, pág. 473-, que “...el principio de buena fe previsto en el art. 1258 del $\mathrm{CC}$, en el ámbito de las relaciones contractuales administrativas, tiene la misma virtualidad que en el Derecho privado, siendo sólo el contrato administrativo válido como única fuente de las obligaciones en el Derecho Administrativo, ya que existe la gestión de negocios de la Administración, o la posibilidad del ejercicio de la acción in rem verso $\mathrm{y}$, en consecuencia, la obligación de pago de determinados servicios, lo que resulta incuestionable, tanto si se fundan en el cuasicontrato de negocios ajenos, como si se apoyan en el enriquecimiento injusto que impone al ente público la compensación del beneficio económico recibido".

${ }_{23}$ Se puede consultar el artículo de Manuel Rebollo Puig "La regla nemo auditur en la jurisprudencia contencioso-administrativa (Revista General de Derecho Administrativo, núm. 4, diciembre, 2003, en especial la nota a pie de pág. núm. 41), y su obra, ya citada, El enriquecimiento...

${ }^{24}$ González-Berenguer Urrutia, José Luis, La contratación administrativa, Ed. Municipalia, Madrid, 1966, pág. 100. 
En el actual TRLCSP, encontramos dos artículos muy importantes dedicados a las formalidades contractuales. Por un lado, el art. 28 -Carácter formal de la contratación del sector público- ${ }^{25} \mathrm{y}$, por otro lado, el art. 156 -Formalización de los contratos ${ }^{26}$. De los cuales se exponen los elementos más significativos.

En primer lugar, está expresamente prohibida la contratación verbal. Ya con anterioridad al TRLCAP, que mantiene la misma prohibición, podemos encontrar un articulado con el mismo sentido. Recordemos que el art. 41 LCE prohibía contratar verbalmente la ejecución de obras, con independencia de la cuantía, salvo las excepciones establecidas en los arts. 26 y 27 LCE.

En segundo lugar, el contrato debe formalizarse en un documento

${ }_{25}$ Este tercer apartado ha sido añadido por la Ley 34/2010, de 5 de agosto, de modificación de las Leyes 30/2007, de 30 de octubre de 2007, de Contratos del Sector Público, 31/2007, de 30 de octubre de 2007, sobre procedimientos de contratación en los sectores del agua, la energía, los transportes y los servicios postales, y 29/1998, de 13 de julio de 1998, reguladora de la Jurisdicción Contencioso-Administrativa para adaptación a la normativa comunitaria de las dos primeras, BOE núm. 192, de 9 de agosto de 2010; equivalente al artículo 55 TRLCAP.

Art. 28. "1. Los entes, organismos y entidades del sector público no podrán contratar verbalmente, salvo que el contrato tenga, conforme a lo señalado en el artículo 97.1, carácter de emergencia. 2. Los contratos que celebren las Administraciones Públicas se formalizarán de acuerdo con lo previsto en el artículo 140, sin perjuicio para lo señalado para los contratos menores en el artículo 95. 3. Los contratos que celebren otros entes, organismos y entidades del sector público, cuando sean susceptibles de recurso especial en materia de contratación conforme al artículo 310.1 deberán formalizarse en los plazos establecidos en el artículo 140.3.”

${ }^{26}$ Este artículo también ha sido modificado por la Ley 34/2010, de 5 de agosto; equivalente al art. 54 TRLCAP. En la Ley de Contratos de 1965, se hace alusión de forma vehemente a este tema en diversos artículos, entre otros el art. 39, 40, 70 y 89.

“Artículo 156. Formalización de los contratos. 1. Los contratos que celebren las Administraciones Públicas deberán formalizarse en documento administrativo que se ajuste con exactitud a las condiciones de la licitación, constituyendo dicho documento título suficiente para acceder a cualquier registro público. No obstante, el contratista podrá solicitar que el contrato se eleve a escritura pública, corriendo de su cargo los correspondientes gastos. En ningún caso se podrán incluir en el documento en que se formalice el contrato cláusulas que impliquen alteración de los términos de la adjudicación. 2. En el caso de los contratos menores definidos en el artículo 138.3 se estará, en cuanto a su formalización, a lo dispuesto en el artículo 111.3. Si el contrato es susceptible de recurso especial en materia de contratación conforme al artículo 40.1, la formalización no podrá efectuarse antes de que transcurran quince días hábiles desde que se remita la notificación de la adjudicación a los licitadores y candidatos. Las Comunidades Autónomas podrán incrementar este plazo, sin que exceda de un mes. El órgano de contratación requerirá al adjudicatario para que formalice el contrato en plazo no superior a cinco días a contar desde el siguiente a aquel en que hubiera recibido el requerimiento, una vez transcurrido el plazo previsto en el párrafo anterior sin que se hubiera interpuesto recurso que lleve aparejada la suspensión de la formalización del contrato. De igual forma procederá cuando el órgano competente para la resolución del recurso hubiera levantado la suspensión. En los restantes casos, la formalización del contrato deberá efectuarse no más tarde de los quince días hábiles siguientes a aquel en que se reciba la notificación de la adjudicación a los licitadores y candidatos en la forma prevista en el artículo 151.4. 4. Cuando por causas imputables al adjudicatario no se hubiese formalizado el contrato dentro del plazo indicado, la Administración podrá acordar la incautación sobre la garantía definitiva del importe de la garantía provisional que, en su caso hubiese exigido. Si las causas de la no formalización fueren imputables a la Administración, se indemnizará al contratista de los daños y perjuicios que la demora le pudiera ocasionar. 5. No podrá iniciarse la ejecución del contrato sin su previa formalización, excepto en los casos previstos en el artículo 113 de esta Ley." 
administrativo. Hemos de recordar que en la LCAP - art. 54- se indicaba que el documento administrativo constituía título suficiente para acceder a cualquier registro público, pudiendo, no obstante, elevarse a escritura pública cuando lo solicitase el contratista (en el mismo sentido queda establecido en el actual art. 156 TRLCSP).

$\mathrm{Y}$ en tercer lugar, el plazo de formalización de los documentos administrativos.

\section{Modificación de los contratos ${ }^{27}$}

Un breve repaso del tratamiento de la modificación de los contratos nos posibilita exponer algunas ideas en consonancia con el tema del carácter formal de los contratos. Hay no obstante que indicar que aunque normalmente se le aplica un sentido amplio al concepto de modificación de los contratos, una cosa es la novación objetiva, como bien hace resaltar Calvo y Ruata ${ }^{28}$, que conllevaría la reforma o la alteración del contenido del proyecto que lo adjudicó, y otra las obras complementarias, que en todo caso tienen carácter accesorio al proyecto original, es decir, no modifican el contrato origen sino que suponen la articulación de un contrato distinto, hecho importante que merece que realicemos algunas consideraciones en epígrafes distintos.

\footnotetext{
${ }^{27}$ Para mayor profundidad en el estudio de la "modificación de los contratos" puede consultarse la siguiente bibliografía, que en todo caso, no tiene carácter exhaustivo: Arino Sánchez, Rafael y Sastre Beceiro, Mónica, "Comentario al artículo 101", en Comentarios a la Ley de Contratos de las Administraciones Públicas, Ariño y Asociados, Tomo III -La gestión del Contrato-, Ed. Comares, Granada, 2005, págs. 803 y ss., págs. 783 y ss.; García de la Mata, José Enrique, "Reflexión sobre la modificación de los contratos en la Ley 30/2007, de 30 de octubre, de contratos del sector público", Diario La Ley, núm. 6983, 2008; García Rubio, Fernando, "Procedimiento a seguir por las Administraciones Públicas en las modificaciones de los contratos de concesión de obra pública (I)", Actualidad administrativa, núm. 3, 2010, pág. 3; Martín Rebollo, Luis, "Modificación de los contratos y consecuencias patrimoniales de las modificaciones irregulares: (con especial referencia al contrato de obras)", en Comentario a la Ley de contratos de las Administraciones públicas, Coord. Rafael Gómez-Ferrer Morant, Ed. Cívitas, 2004, págs. 575-659; Molina Barrero, Encarnación, Such Martínez, Javier, Domech López, Juan, Regli Criveli, Carmen, "La Ley de Contratos de las Administraciones Públicas. Especial referencia a la modificación y resolución de contratos", II Seminario sobre aspectos jurídicos de la gestión universitaria: Universidad de Murcia del 11 al 13 de diciembre de 1996, 1999, págs. 479-524; Vázquez Matilla, Francisco Javier, "La modificación de los contratos administrativos: reflexiones en torno a la STJCE de 29 de abril de 2004 y la Ley de Contratos del Sector Público", REDA, núm. 2009, págs. 529-564.

${ }^{28}$ Calvo y Ruata, Pablo, "El contrato público de obra (con especial referencia al contrato públicoadministrativo de obra)", en Estudios sobre la ley de contratos del sector público, Coords. Colas Tenas, Jesús, y Medina Guerrero, Manuel, Ed. Fundación Democracia y Gobierno Local-Instituto Fernando El Católico, Madrid, 2009, pág. 335.
} 
En la $\mathrm{LCE}^{29}$, el art. 48 determinaba que una vez perfeccionado el contrato, la Administración sólo podía modificar los elementos que lo integran, dentro de los límites ${ }^{30}$ de la propia LCE y su reglamento ${ }^{31}$.

El TRLCAP dedicaba varios preceptos a la modificación de los contratos, de los cuales podemos extraer, entre otras conclusiones que excederían el presente estudio, que el órgano de contratación sólo podía introducir modificaciones por razón de interés público siempre que las mismas sean debidas a necesidades nuevas o causas imprevistas, justificándolo debidamente en el expediente y debiéndose formalizar de forma obligatoria según las prescripciones del artículo 54 TRLCAP.

Debemos subrayar en que se trata de una prerrogativa de la Administración, es decir, se trata de una facultad que colisiona con el principio de intangibilidad ${ }^{32}$, es decir, tras hacer uso la Administración de la

29 Sastre Beceiro (Arino Sánchez, Rafael y Sastre Beceiro, Mónica, "Comentario...", Op. cit., págs. 804 y 805) retrotrae el ius variandi en materia de contratos hasta el Real Decreto de 10 de octubre de 1845, que aprueba la instrucción de promover y ejecutar las obras públicas, concretamente en los artículos 10, 19 y 33.7. Asimismo, hace alusión, en el repaso histórico sobre este tema, a las siguientes normas: Pliego de Condiciones de 1846, arts. 3, 6, 15, 20 y 35; R.O. de 10 de julio de 1861 y R.O. de 7 de diciembre de 1900; Pliego de Condiciones de 1903, Capítulo IV; la Ley de Administración y Contabilidad de 1 de julio de 1991, art. 59; LCE de 8 de abril de 1965, art. 48; Ley de Reforma de Contratos del Estado de 17 de marzo de 1973, art. 48; y Reglamento de Contratos del Estado de 25 de noviembre de 1975, art. 146.

${ }^{30}$ Uno de estos límites, por ejemplo, se recogía en el art. 52.2 LCE, en el que se indicaba que no podía ser superior al $20 \%$ del presupuesto total. Con posterioridad, y tras la aprobación del Real Decreto Legislativo 781/1986, de 18 de abril, Texto refundido de las disposiciones legales vigentes en materia de Régimen Local (BOE núm. 96, de 22 abril de 1986), hay que tener en cuenta lo que se dispone en el art. 114.1 y 3: "1. El órgano de la Entidad local competente para contratar según la Ley ostenta también la prerrogativa de interpretar los contratos administrativos y resolver las dudas que ofrezca su cumplimiento. Igualmente, podrá modificar, por razón de interés público, los contratos celebrados y acordar su resolución dentro de los límites y con sujeción a los requisitos y efectos señalados legalmente. 3. Los acuerdos que, previo informe de la Secretaría y de la Intervención de la Corporación, dicte el órgano competente, en cuanto a la interpretación, modificación y resolución de los contratos serán inmediatamente ejecutivos. En los casos de interpretación y resolución, cuando el precio del contrato exceda de la cantidad fijada por la legislación estatal sobre contratación administrativa, y en los de modificación de estos últimos, cuando la cuantía de aquélla exceda del 20 por 100 del precio del contrato, será, además, preceptivo el dictamen del órgano consultivo superior de la Comunidad Autónoma, si existiere o, en su defecto, del Consejo de Estado."

${ }^{31}$ Algunos de estos límites los encontramos en el artículo 52.2 LCE, que concreta un límite al poder de modificación de los contratos, cifrándolo en un 20 por 100 del presupuesto total. También el artículo 51 del Reglamento de Contratación de las Corporaciones locales indica: "Los contratos serán inalterables a partir de su perfeccionamiento y deberán ser cumplidos con estricta sujeción a sus cláusulas y a los pliegos que les sirvan de base... salvo las excepciones expresamente admitidas por los artículos siguientes."

32 Sobre esta observación, y en general sobre el contenido del art. 59 puede consultarse el estudio de Villar Ezcurra, José Luis, y Marfa Badaroux, Jaime, "Comentario al artículo 59 TRLCAP”, en Comentarios a la Ley de Contratos de las Administraciones Públicas, Ariño y Asociados, Tomo II -La gestación del Contrato-, Ed. Comares, Granada, 2003, págs. 783 y ss. 
prerrogativa de modificación del contrato - causa-, se produce un efecto en el contratista como consecuencia de un acto unilateral de la Administración, que bien podría ser que tuviese como consecuencia una pérdida de carácter económico que el particular no tendría que soportar, hecho que a tal efecto tendría la consecuencia de un supuesto de antijuridicidad en la actuación administrativa, de donde se deduce que surge un derecho indemnizatorio a favor del contratista ${ }^{33}$-principio de equilibrio económico-.

Queda de manifiesto que la Administración no puede realizar una modificación del contrato a su antojo, sino que es imprescindible que se pueda justificar la modificación del contrato con base a razones de interés público; expresamente indica el art. 101.1 TRLCAP que se tiene que tratar de necesidades nuevas o causas imprevistas. Llegados a este punto, pueden ocurrir dos cuestiones: que bien se hubiese valorado y descartado por la Administración contratante la modificación, lo que conllevaría a tener que plantear una nueva modificación, o bien que realmente se trate de una necesidad nueva o una causa imprevista.

La regulación de la modificación de los contratos en la LCSP ha sido también muy interesante. Podemos distinguir dos etapas perfectamente diferenciadas: la primera, hasta la aprobación de la Ley de Economía Sostenible; la segunda, a partir de la misma.

En la primera de etapa, desde la entrada en vigor de la LCSP hasta la aprobación de la Ley de Economía Sostenible, son varios los preceptos que se encargan de articular este tema: art. 202 -Modificaciones de los contratos-, art. 217 -Modificación del contrato de obras-, art. 258 -Modificación del contrato y mantenimiento de su equilibrio económico-, art. 272 -Modificación del contrato de suministro-, y art. 282 -Modificación de los contratos de servicios de mantenimiento-.

Respecto a los intereses concretos del estudio, la formalización, el apartado tercero del art. 202 LCSP se remite al procedimiento descrito en el art. 140 LCSP, recientemente modificado por la Ley 34/2010, de 5 de agosto, y que teniendo como equivalente el art. 54 TRLCAP, ya hemos tenido la oportunidad de indicar su contenido más relevante.

En la segunda etapa, con la aprobación de la Ley de Economía Sostenible (Ley 2/2011, de 4 de febrero) se dio un importante paso en la regulación de la modificación contractual en el ámbito del sector público. Estos cambios

33 Así se recoge, por ejemplo, en el art. 146.1 TRLCAP-Modificación del contrato de obras-, en el que se dispone: "Serán obligatorias para el contratista las modificaciones en el contrato de obras que, con arreglo a lo establecido en el artículo 101, produzcan aumento, reducción o supresión de las unidades de obra o sustitución de una clase de fábrica por otra, siempre que ésta sea una de las comprendidas en el contrato. En caso de supresión o reducción de obras, el contratista no tendrá derecho a reclamar indemnización...". 
fueron introducidos con fiel exactitud en el TRLCSP, texto que asumió ad litteram los preceptos redactados por la Ley 2/2011.

Finalmente, y tras la aprobación de la Directiva 2014/24/UE, de 26 de febrero, Directiva que deroga la Directiva 2004/18/CE -DOL de 28 de marzo de 2014, núm. 94- el tema en estudio también debe ser objeto de una futura modificación (modificación de los contratos durante su vigencia -art. 72-) ${ }^{34}$. De acuerdo con la Directiva, una modificación sustancial de las disposiciones de un contrato público durante su período de vigencia se considerará una nueva adjudicación a efectos de la Directiva y requerirá un nuevo procedimiento de contratación de conformidad con ella.

Una modificación se considerará sustancial cuando se cumpla una de las condiciones siguientes: a) que la modificación introduzca condiciones que, de haber figurado en el procedimiento de contratación inicial, habrían permitido la selección de candidatos distintos de los seleccionados inicialmente o la adjudicación del contrato a otro licitador; b) que la modificación altere el equilibrio económico del contrato en beneficio del contratista; c) que la modificación amplíe de forma considerable el ámbito del contrato para abarcar suministros, servicios u obras no previstos inicialmente (art. 72.2).

\section{Las obras complementarias}

Tal y como hemos indicado con reiteración, las obras complementarias contienen un matiz particular respecto a la modificación de los contratos porque son la manifestación de una voluntad accesoria distinta a la contenida en el contrato origen y que, por tanto, debe plasmarse en un contrato distinto ${ }^{35}$.

La base interpretativa la podemos encontrar en el Dictamen del Consejo de Estado núm. 424 de 2 de abril de 1992, que señala:

"La diferencia entre obras complementarias y modificación no aparece clara en todos los casos concretos. Con carácter general, este Consejo ha indicado que son criterios aplicables para la distinción entre una y otra la posibilidad

\footnotetext{
${ }^{34}$ Para mayor profundidad sobre el tema puede consultarse el trabajo de Francisco Eusebio Puerta Seguido, Jesús Punzón Moraleda, Alma Patricia Domínguez Alonso, "La nueva regulación en la Directiva de la fase de ejecución de los contratos y la repercusión de la jurisprudencia del TJUE en materia de modificación de contratos", Contratación administrativa práctica: revista de la contratación administrativa y de los contratistas, núm. 129, 2014, págs. 22-34.

35 La doctrina de forma unánime coincide, por otra parte, con esta interpretación. Así, por ejemplo, puede consultarse: AA.VV., Comentarios a la legislación de Contratación Pública,

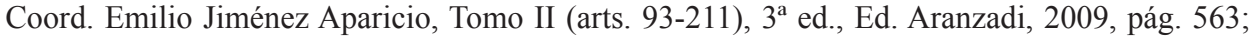
AA.VV., Contratación del Sector Público Local, Tomo I, Ed. El Consultor de los Ayuntamientos (La Ley), 2008, pág. 1255; Contratos de las Administraciones Públicas (Comentarios a la Ley 13/1995, de 18 de mayo), Tomo II, Ed. El Consultor de los Ayuntamientos y Juzgados, Madrid, 1995, pág. 666, etc.
} 
de utilización separada de las obras nuevas, su necesidad en relación al proyecto inicial y las dificultades técnicas de adjudicación y ejecución independientes (Dictámenes núm. 45.942, de 15 de diciembre de 1983, 47.127, de 29 de noviembre de 1984, y 48.034, de 24 de julio de 1985, entre otros)".

En el plano jurisprudencial también podemos encontrar varias sentencias. Por ejemplo, en la Sentencia núm. 819/2009, de 8 de octubre, del Tribunal Superior de Justicia de Galicia (Sala de lo Contencioso-Administrativo, Sección $\left.1^{\text {a }}\right)$, FJ $3^{\circ}$, se establece:

“... son contratos distintos los referidos a la ejecución de una obra principal y los que se refieren a la ejecución de obras complemetarias amparadas por sus correlativos contratos, que han exigido para su celebración una tramitación específica, por lo que, entre otros aspectos, esta tramitación específica implica que el régimen de revisión de precios se debe aplicar específicamente a cada contrato sin poder acumularse al contrato principal las ampliaciones de plazo que se produzcan como consecuencia de modificaciones contractuales".

La consecuencia final de esta distinción tiene como parámetro de reflexión la utilización de cada figura para el fin para el que está dispuesta. La confusión, intencionada o no, o simplemente el desconocimiento sobre el particular, no pueden justificar, obviamente, las actuaciones de los órganos contratantes de la Administración. De utilizar un procedimiento contractual impropio en razón del fin perseguido ${ }^{36}$ la sanción a tal actuación administrativa llevaría aparejada la nulidad de pleno derecho.

\section{La ausencia total y absoluta del expediente de contratación}

\section{A) Tratamiento legal}

La ausencia total y absoluta del expediente de contratación se sancionaba con la nulidad de pleno derecho — art. 62.1, e) LRJPAC "Los dictados prescindiendo total y absolutamente del procedimiento legalmente establecido..."-, al que se remite el art. 62. a) TRLCAP.

En definitiva, tanto en la versión del TRLCAP (art. 65.137) como en la nueva versión de redacción de la LCSP, modificada por la Ley 34/2010, de 5 de agosto, que son idénticas, será en ejecución de sentencia cuando habrá de valorarse las consecuencias que tiene el pronunciamiento estimatorio de la sentencia. ${ }^{38}$ En todo caso, parece obvio que la declaración de nulidad firme lleva aparejada de forma intrínseca la del propio contrato. Nos queda

\footnotetext{
${ }^{36}$ Véase en este sentido a Menéndez Gómez, Emilio, Contratos del Sector Público. Contrato de obras públicas, Ed. Aranzadi, 1ª ed., Cizur Menor (Navarra), 2008, pág. 377.

${ }^{37} \mathrm{El}$ art. 65 fue derogado por la Disp. derogatoria Única a) LCSP; equivalente a art. 35 LCSP.

38 Véase por ejemplo la Sentencia núm. 484/2009, de 6 de noviembre, del Tribunal Superior de Justicia de Castilla y León, Burgos (Sala de de lo contencioso-Administrativo, Sección 1 ${ }^{\mathrm{a}}$ ) (FJ $5^{\mathrm{o}}$ ).
} 
alguna duda sobre cómo puede entenderse la propia invalidez de las cláusulas contractuales, que entendemos no tiene un tratamiento similar al régimen de la ilegalidad de los actos preparatorios y de adjudicación. Para Santamaría Pastor $^{39}$ la cuestión plantea problemas, puesto que "la invalidez de los actos preparatorios determina la nulidad de todo el contrato, en tanto que la invalidez de una o varias de las cláusulas integrantes del contrato, puede dar lugar, en hipótesis, bien sólo a la nulidad (o anulabilidad) de las mismas, bien a la de todo el contrato".

En este sentido, hemos de tener en cuenta el art. 145.1 TRLCSP (art.129.1 LCSP) determina que las proposiciones de los interesados deberán ajustarse a lo previsto en el pliego de cláusulas administrativas particulares, y su presentación supone la aceptación incondicionada por el empresario del contenido de la totalidad de dichas cláusulas o condiciones, sin salvedad o reserva alguna, de donde se puede deducir que la invalidez de los pliegos, si no se impugnan en tiempo y forma, es complicado que pueda afectar al contrato. $^{40}$

\section{B) La ausencia de contrato}

Catalá Martíi ${ }^{41}$ expone un ejemplo típico:

“... prestaciones que el particular, de buena fe, cumple, dando por correcto y ajustado a derecho lo pactado con la Administración y después ésta no procede al pago de lo convenido, cargando sobre el contratista los errores sólo imputables a la misma, excusándose en que no existió una contratación con las formalidades correspondientes, y que de existir habría que considerarla nula de pleno derecho."

El ejemplo expuesto pone de manifiesto que, en ocasiones, la propia Administración pudiera no seguir el procedimiento reglado y que no por ello, en principio, podría desentenderse de las obligaciones contraídas, insistimos, al margen del procedimiento establecido en el TRLCAP. Estaríamos ante un supuesto de contratación verbal que extendería ciertas obligaciones al contratista por una contraprestación económica a la que debe obligarse de la Administración, hecho que por todos es conocido que está prohibido -

\footnotetext{
39 Santamaría Pastor, Juan Alfonso, "La invalidez de los contratos públicos", en Comentario a la Ley de Contratos de las Administraciones Públicas, Dir. Gómez Ferrer Morant, R., pág. 320, 1996. 40 Moreno Molina, José Antonio, y Pleite Guadamillas, Francisco (La nueva Ley de Contratos del Sector Público, $2^{\mathrm{a}}$ ed., Ed. La Ley, Las Rozas (Madrid), 2009, pág. 396), hacen hincapié en la cuestión aludida en el texto, puesto que no se alude a los efectos de las cláusulas del contrato, indicando que, no obstante, la jurisprudencia ha asumido la posibilidad de declarar la nulidad parcial (Sentencia del TS de 10 de diciembre de 2004).

${ }^{41}$ Catalá Martí, José Vicente, Manual práctico de contratación de las entidades locales, Ed. Bayer Hnos., Barcelona, 2007, pág. 283.
} 
salvo en situaciones de emergencia- en la legislación de contratación (art. 55 TRLCAP ${ }^{42}$.

En este sentido es ilustrativa la Sentencia núm. 1268/2009 de 8 de octubre, del TSJ C. Valenciana (Sala de lo Contencioso-Administrativo, Sección $\left.3^{\mathrm{a}}\right)^{43}$. Resulta evidente, como se afirma en la Sentencia, que los contratos

42 “Artículo 55. Contratación verbal. La Administración no podrá contratar verbalmente, salvo que el contrato tenga carácter de emergencia." (Derogado por la Disp. derog. única.a) LCSP; equivalente al art. 28 LCSP.

${ }^{43} \mathrm{FJ} 4^{\circ}$ : "En el presente litigio, la sociedad recurrente ejercita una pretensión de cobro de intereses de demora por el pago extemporáneo por la Consellería de Sanidad de diversas facturas derivadas del suministro de medicamentos. (...)

Centrada la cuestión en decidir la normativa aplicable en el cálculo del interés de demora, la primera cuestión a resolver es lógica: averiguar la fecha del contrato administrativo de suministro para determinar la norma aplicable para el cálculo del interés de demora. Es decir, a los contratos formalizados antes del 8-8-2002 les será de aplicación el tipo de interés previsto en artículo 100.4 de la LCAP, actual artículo 99.4 del TRLCAP, y a los contratos perfeccionados después de esa fecha se le aplicará el artículo 7 de la Ley 3/2004 (tipo de interés) y artículo 8 (costes de cobro), lo que deja debidamente enfocada la cuestión y con una muy sencilla solución.

El motivo del anterior razonamiento es evidente y de necesaria referencia a nuestro marco legal de contratación, pues si estamos ante un contrato de suministro, su concepto vendrá dado por la existencia de un contrato administrativo por el que una parte hace entrega sucesiva de bienes, sin previa determinación de su cuantía total, a cambio de un precio unitario, supeditado todo a las necesidades de la Administración durante la vigencia del contrato.

El ordenamiento jurídico español regula minuciosamente el procedimiento de contratación: acuerdo de iniciación de un expediente de contratación, aprobación de un pliego de cláusulas administrativas particulares y prescripciones técnicas, aprobación del gasto previsto y su consignación presupuestaria, publicidad y concurrencia en la convocatoria, adjudicación mediante concurso, subasta o procedimiento negociado y, seguidamente, formalización del contrato con el adjudicatario, permitiendo con ello dar validez y eficacia a un contrato de suministros de material sanitario, para así proceder a su pertinente ejecución (pedidos hospitalarios, suministros, facturación y correspondiente pago del precio convenido).

Tal formalización contractual escrita no es caprichosa, pues el artículo 55 del TRLCAP prohíbe explícitamente la contratación verbal, salvo emergencias, que no es el caso, de manera que cualquier discusión que pase por dilucidar la norma aplicable a un contrato de suministro requerirá, precisamente, conocer ese contrato a fin de saber su fecha y las condiciones contractuales para así resolver la cuestión y atender congruentemente a las pretensiones deducidas en el proceso.

Sin embargo, mientras la contestación a la demanda del Letrado de la Generalitat Valenciana hace gala de una ambigüedad y falta de precisión jurídica ostensible al respecto, sin aportar algo tan obvio y relevante como es el contrato de suministro que debe ser la causa de las reclamaciones económicas de la demanda, la demanda es clara al afirmar que no había contrato, que se trataba de pedidos telefónicos contra suministros más facturas, llegando a la errónea conclusión de que tal situación irregular se salvaba con la factura. Es decir, el sistema que se sigue es ilegal pero la fuerza de la costumbre lo subsana todo, pelillos a la mar, poniendo en evidencia que en el ámbito de la sanidad pública lo usual es no aplicar los procedimientos previstos en la ley, como si el Estado de Derecho no tuviera a bien penetrar en el ámbito de la contratación de suministros hospitalarios. Naturalmente, se comete nuevamente el error jurídico de equiparar fecha de contrato con fecha de factura, ignorando de manera interesada que no puede inventarse el ordenamiento jurídico, que también en el ámbito de la contratación administrativa rige el principio de legalidad. 
Se dice por la demandada que los contratos, aunque irregulares, fueron posteriores al 8-8-2002, mientras que la Administración de la Generalitat Valenciana niega la aplicación de la Ley 3/2004 y sus nuevos tipos de interés en caso de demora.

Ante esta situación, esta Sala no puede admitir la equiparación entre contrato y suministro e impone a la actora las consecuencias de la falta de prueba de la fecha de formalización del contrato de suministro, con la consecuente desestimación de una pretensión de cobro de intereses fundamentada en la Ley 3/2004, pues está reconocido por la actora que no existe un contrato de suministros debidamente adjudicado y formalizado para permitir el adecuado conocimiento de una $\mathrm{u}$ otra normativa jurídica sobre los intereses de demora controvertidos.

En efecto, el artículo 54.1 del TRLCAP establece que "los contratos de la Administración se formalizarán en documento administrativo dentro del plazo de treinta días a contar desde el siguiente al de la notificación de la adjudicación...", añadiendo el apartado 4 de dicho precepto que "no se podrá iniciar la ejecución del contrato sin la previa formalización, excepto en los casos previstos en los artículos 71 y 72 (contratos urgentes y de emergencia)".

De lo expuesto se deduce que la formación y expresión de la voluntad administrativa de celebrar un determinado contrato se realiza a través de un procedimiento administrativo y acaba plasmándose en un acto administrativo, el de adjudicación, que es al propio tiempo el de perfección del contrato. La Administración actúa sometida necesariamente al principio de legalidad, a través de un procedimiento minuciosamente regulado, y dicta un acto administrativo escrito que culmina el procedimiento de selección.

También queda claro que la formalización documental del contrato es obligatoria y constituye un presupuesto de eficacia del mismo, de manera que las partes sólo pueden reclamar el cumplimiento o ejecución del contrato cuando éste ha sido documentado. Por ello, debe sentarse que el documento administrativo en que se formaliza el contrato opera como un requisito de eficacia hasta el punto que sin su formalización no cabe iniciar la ejecución, salvo supuestos de tramitación urgente o de emergencia.

En resumen, los contratos se perfeccionan y son válidos una vez son adjudicados pero su eficacia queda demorada hasta en tanto se formalizan por escrito. La falta de esta formalización del contrato supone la imposibilidad de iniciar su ejecución, constituyendo una de las causas de resolución del contrato (artículo 111.d) TRLCAP), en caso, claro está, de que exista un procedimiento administrativo y una adjudicación previa.

Por otra parte, tampoco cabe acudir a la contratación verbal como forma válida de contratación, habida cuenta la dicción del ya mencionado artículo 55 del TRLCAP, que establece que "la Administración no podrá contratar verbalmente, salvo que el contrato tenga carácter de emergencia", lo que no deja de ser una norma superflua o redundante, puesto que si la Ley prescribe que no puede prescindirse del procedimiento formalmente establecido para contratar y el contrato concertado al margen de dicho procedimiento será nulo, el texto del artículo 55 no deja de ser una reiteración obvia de la obligatoriedad de contratar conforme al procedimiento legalmente establecido.

Las consecuencias de realizar en el presente supuesto litigioso una contratación verbal, entendida como encargo hecho a un contratista prescindiendo de toda formalidad y al margen del procedimiento legalmente establecido previsto, acarrea como primer efecto jurídico el de la nulidad del contrato celebrado, en aplicación del artículo 62.1.e) de la Ley 30/1992, de 26 de noviembre, en relación al artículo 62.a) del TRLCAP, habida cuenta que se ha prescindido total y absolutamente del procedimiento legalmente establecido.

La segunda consecuencia sería, en caso de haberse producido actos de ejecución material de ese contrato nulo (prestación de suministros), entender que se ha producido para la Consellería de Sanidad un enriquecimiento sin causa o injustificado, lo que determinaría la necesidad de restituir al contratista el valor de su prestación o, como establece el artículo 65.1 del TRLCAP, la devolución de su valor, pero en forma alguna el pago del precio convenido, pues no se trata de la ejecución de un contrato sino de la destrucción de sus efectos, todo ello con las salvedades previstas en el artículo 65.3 TRLCAP para supuestos de 
se perfeccionan y son válidos una vez adjudicados, pero su eficacia queda demorada hasta en tanto se formalizan por escrito. La Administración "se enriqueció de forma injustificada", lo que se manifiesta en el que se acuerda en la devolución del valor de la prestación del contratista -no el pago del precio convenido, sino la restitución in natura del valor las actividades realizadas debidamente justificadas-.

Tal y como se desprende de lo expuesto anteriormente, si el contrato no se ha perfeccionado según las normas contenidas en la LCSP, no sería correcto hablar de un contrato nulo, sino de la inexistencia del mismo. La consecuencia de la inexistencia del contrato no puede ser, como ya se adelantó, la liquidación del mismo en relación con las actuaciones realizadas por el contratista y que tiene como beneficiaria a la Administración. El problema que subyace es que, en principio, la Administración no podría realizar los pagos pertinentes en contraprestación por las acciones realizadas por el contratista a favor de la Administración, ni pagar en su caso, como bien prevé la LCSP, una indemnización por los daños y perjuicios causados al contratista más los intereses de mora. Por tanto, la Jurisdicción Contencioso-Administrativa, que es la competente para resolver este tipo de asuntos, ha tenido que dar una solución, que no puede ser otra que la basada en la teoría del enriquecimiento sin causa o injusto.

En relación con lo que se acaba de expresar, surge una pregunta: ¿cuándo existe el enriquecimiento injusto? Son numerosas las sentencias que explicitan de forma adecuada tal extremo. Valga por todas la Sentencia de 25 de febrero de 2009, de la Audiencia Nacional (Sala de lo Contencioso-Administrativo, Sección $8^{\mathrm{a}}$ ) -FJ $4^{\mathrm{o}}$-:

"Los requisitos del enriquecimiento injusto, articulados por el Tribunal Supremo, son:

grave trastorno al servicio público sanitario.

En el presente litigio, expuesta la existencia incontrovertida de una contratación verbal (o telefónica) de suministros y, por tanto, nula de pleno derecho, ante el hecho de que los suministros se realizaron a favor de la Consellería de Sanidad y fueron pagados, si bien de forma extemporánea, a fin de evitar el enriquecimiento injusto de dicha Administración al haber abonado de forma tardía las facturas aceptadas, dejando bien sentado que no puede prosperar la tesis de la demanda de someter los contratos a la Ley 3/2004 por no existir una contratación posterior a 8-8-2002, procederá sentar los siguiente criterios (...).”

"FALLO: Que debemos estimar y estimamos el recurso interpuesto por la representación procesal de la parte actora, contra el acuerdo expresado en el encabezamiento, anulando dicho acuerdo por no ser ajustado a Derecho y se declara el derecho de la actora a la declaramos dicha Sociedad tiene derecho a que el Ayuntamiento demandado le abone, la cantidad de 7.363 .808 pts $(44.287,4 €)$ más los intereses legales de esa suma, a partir de los nueve meses de la fecha en que se concluyeron las entregas de materiales y prestación de servicios reclamados, todo ello sin imposición de costas a ninguna de las partes." 
a) El enriquecimiento o aumento del patrimonio del enriquecido, constituido por cualquier ventaja o atribución patrimonial abocada a producir efectos definitivos.

b) El empobrecimiento de quien reclama o de aquel en cuyo nombre se reclama, pecuniariamente apreciable, aunque entendido en su más amplio sentido, siempre que no provenga directamente del comportamiento de quien lo sufre.

c) La relación causal entre el empobrecimiento y el enriquecimiento, de forma que éste sea el efecto de aquél. O, dicho en otros términos, que al enriquecimiento siga un correlativo empobrecimiento.

d) La falta de causa o de justificación del enriquecimiento y del correlativo empobrecimiento."

Se trata de una corrección al postulado de la inalterabilidad de los contratos administrativos que exige, en los supuestos normales, connivencia entre la Administración y cuasi contratista, es decir, una expresión de la voluntad al margen de la regulación contractual.

Otro elemento que surge de forma constante en las sentencias analizadas es la gestión de negocios de la Administración ${ }^{44}$ o negotiorum gestio ${ }^{45}$. Se trata de supuestos en los que la Administración compensa al cuasi contratista por el beneficio que la misma obtiene en función de una actividad realizada por aquel. Al tratarse de cuasi contratos, tenemos que entender que se trata de una institución parecida a los contratos pero que se diferencia de ésta en que le falta algún elemento esencial.

Ya en Derecho romano aparece contemplada en el Digesto -título V del Libro III, La gestión de los negocios- mediante la cual se intentaba explicar aquellas situaciones en las que sin mediar acuerdo o mandato, se realizaba la gestión de los negocios de otra persona ausente; esta acción producía derechos y obligaciones recíprocas para las dos partes $^{46}$.

\footnotetext{
${ }^{44}$ Entre otras sentencias que reconocen la denominada "gestión de negocios de la Administración", pueden consultarse: JCA Guadalajara (Castilla-La Mancha), núm. 1, sentencia núm. 30/2007 de 31 de enero; TS (Sala de lo Contencioso-Administrativo, Sección $7^{\mathrm{a}}$ ), sentencia de 22 de mayo de 2000; TSJ Asturias (Sala de lo Contencioso-Administrativo, Sección 2aa), sentencia núm. 508/2001 de 29 de mayo; TS (Sala de lo Contencioso-Administrativo), sentencia de 13 de julio de 1984; TS (Sala de lo Contencioso-Administrativo), sentencia de 29 de octubre de 1980, etc.

${ }^{45}$ Puede consultarse en referencia a su aplicación en el ámbito público de esta figura: ÁlvarezGendin y Blanco, Sabino, Los contratos públicos, Madrid, 1934, págs. 10 a 14.

${ }^{46}$ Véase para mayor profundidad el estudio de Gimenez Barriocanal, Fernando, La actividad económica en el derecho Romano: Análisis contable, Editorial Dykinson, 2003, pág. 406.
} 
Parece claro por las razones expuestas que la conclusión debe orientarse sobre la conveniencia o preferencia de la actio in rem verso sobre la negotiorum gestio, al menos en relación con aquellos supuestos en los que medie encargo o mandato por parte de la Administración. Con referencia al art. 1893 del Código Civil, disposición prevista para el supuesto de que el favorecido no ratifique la gestión realizada, en el caso que nos ocupa por el cuasi contratista, la solución se traslada en gran parte a las dadas para estos supuestos en los ámbitos de los contratos públicos. En efecto, la Administración debe "indemnizar" al cuasi contratista por los gastos necesarios y útiles que hubiese hecho, aunque tenemos importantes dudas respecto a los perjuicios que hubiese podido sufrir por la realización de su acción. Entendemos que incluir los perjuicios más allá del empobrecimiento sufrido sería desequilibrar sin justa causa los derechos, obligaciones y deberes que se desprenden de este tipo de situaciones. Por el contrario, si estamos de acuerdo, según se dispone en el párrafo segundo del art. 1893 del Código Civil. En caso de intentar evitar un sujeto -en este caso si podemos denominarlo sin ambages como "gestor de negocios ajenos sin mandato"-, algún perjuicio inminente y manifiesto a la Administración, y aún sin provecho para el primero, tendríamos que acoplarlo a la tramitación de urgencia regulada en el art. 97 LCSP.

Por las razones expuestas, tanto la negotiorum gestio como la actio in rem verso debemos asumirlas con absoluta normalidad aunque dependiendo de los supuestos concretos; mientras que la negotiorum gestio se puede aplicar, por ejemplo, según ocurrió en la Sentencia del Tribunal Supremo (Sala de lo Contencioso-Administrativo, Sección 7 $7^{\text {a }}$, de 23 de junio de 1999, en la que una persona física contrata con la Administración a favor de una persona jurídica que estaba en trámites de constitución. Pues bien, en virtud de que el Código Civil establece la validez del contrato en nombre de otro, si éste lo ratifica, aunque no haya autorizado previamente al contratante, la contratación sería válida según la doctrina de la gestión de negocios ajeno sin mandato, supuesto que se recoge en el art. 46.2 LCSP.

\section{Conclusiones}

La primera idea que nos parece relevante exponer es la actualidad que aún tiene en nuestros días la actio in rem verso. Lejos de recurrir a pretensiones del pasado en una situación jurídica distinta y en la que materias como la contratación administrativa prácticamente se encontraban en un estadio incipiente de implantación, donde de una forma u otra resultaba más lógica, al menos si tenemos en cuenta las circunstancias jurídicas propias de la 
evolución de nuestro ordenamiento jurídico, la utilización de este tipo de acciones para cubrir determinadas lagunas jurídicas, debemos concluir que pese a las últimas regulaciones que han acaecido en materia de contratos administrativos, no queda cubierta la multiplicidad de variantes que pueden surgir, y que como partícipes de un ordenamiento jurídico eficaz, dinámico y lleno de vitalidad, debemos solucionar de la forma más justa y equitativa si tenemos en cuenta dados los importantes intereses -entre otros los de tipo económico- que suelen debatirse en este tipo de materias.

La segunda idea importante es que de forma repetitiva nos hemos encontrado con una relación causa-efecto que ha tenido como transfondo el enriquecimiento injusto de la Administración, hecho que se ha valorado de forma indubitada por la jurisprudencia como una acción desequilibrante de la Administración, pues es ésta, y en menor proporción los contratistas, la que debe siempre salvaguardar la legalidad de sus actuaciones contractuales -principio de legalidad, y las de terceros -licitadores- que hipotéticamente pueden intervenir en las relaciones contractuales que desarrollan las Administraciones Públicas, por lo que también hemos de tener presente los principios de publicidad y concurrencia que aseguran los derechos de eventuales licitadores y de la propia Administración en el marco de un procedimiento contractual. Retomando los diversos incisos jurisprudenciales sobre esta cuestión que exponemos, hemos de recordar que existe unanimidad en el marco de la Jurisdicción Contencioso-Administrativa de que la Administración, como entidad pública, es la encargada de velar, en primer lugar y antes que nadie, porque se cumplan todas las exigencias legales para la adecuada adjudicación, formalización y control de los contratos que lleve a cabo, y que no puede excusarse en tan inicuo motivo, imputable fundamentalmente a ella misma, para enriquecerse a costa del patrimonio particular de los particulares -contratistas-.

La tercera idea conclusiva es que, a nuestro juicio, utilizada la actio in rem verso en el supuesto apropiado, el contratista no puede pedir daños y perjuicios a la Administración.

Aunque en la relativamente abundante jurisprudencia sobre la materia se intenta justificar la existencia de un enriquecimiento injusto con base en la negotiorum gestio y en la actio in rem verso, a nuestro juicio, resulta desde un punto de vista más apropiado basar los fallos de las sentencias en la acción in rem verso, puesto que para que se cumpla la figura de la negotiorum gestio falta como elemento caracterizador la espontaneidad del "cuasi contratista" a la hora de realizar la actividad a favor de la Administración.

Finalmente, hemos de poner de relieve que las consecuencias que se 
derivan de la inexistencia de contrato o de alguna derivación que no haga posible definir la pseudo relación contractual como ajusta a la LCSP es que el "cuasi contratista" sólo puede pretender el reembolso de los gastos útiles realizados con base en el empobrecimiento que tiene que soportar, mientras que la otra parte, la Administración, se enriquecería de forma injustificada. De ahí que el Juez tenga que ser muy diligente a la hora de valorar este tipo de casos, en los que edeben evaluar de forma tasada la actividad, obra o servicio realizado, nunca con base en el posible precio fijado o pactado, sino en el gasto que el cuasi contratista deprecia su patrimonio.

Es cierto que la justificación material siempre está basada en la actuación de buena fe del cuasi contratista y que en virtud del principio de equidad hay que resolver la situación cuasi contractual. 


\section{Bibliográficas}

\section{REFERENCIAS}

AA.VV., "Comentario al artículo 25", en Comentarios a la Legislación de Contratación Pública, Coord. Emilio Jiménez Aparicio, Tomo I, Ley 30/2007, de 30 de octubre de Contratos del Sector Público (Arts. 1 a 92), Ed. Aranzadi, $3^{a}$ ed., Cizur Menor (Navarra), 2009.

AA.VV., Comentarios a la legislación de Contratación Pública, Coord. Emilio Jiménez Aparicio, Tomo II (arts. 93-211), $3^{\text {a }}$ ed., Ed. Aranzadi, 2009.

AA.VV., Contratación del Sector Público Local, Tomo I, Ed. El Consultor de los Ayuntamientos (La Ley), 2008.

AA.VV., Estudios sobre la ley de contratos del sector público, Coords. COLÁS TENAS, Jesús, y Medina Guerrero, Manuel, Ed. Fundación Democracia y Gobierno Local-Instituto Fernando El Católico, Madrid, 2009.

Alonso Higuera, Carmen, "Ley de contratos del sector público: ámbito de aplicación. Modalidades contractuales y régimen de invalidez de los procedimientos de contratación", en Estudios sobre la Ley de contratos del sector público, Coord. Jesús

Colás Tenas y Manuel Medina Guerrero, Ed. Fundación Democracia y Gobierno Local-Institución Fernando El Católico, Madrid, 2009.

Álvarez-Gendin y Blanco, Sabino, Los contratos públicos, Madrid, 1934.

Arino Sánchez, Rafael y Sastre Beceiro, Mónica, "Comentario al artículo 101", en Comentarios a la Ley de Contratos de las Administraciones Públicas, Ariño y Asociados, Tomo III -La gestión del Contrato-, Ed. Comares, Granada, 2005.

Ballesteros Fernández, Ángel, Manual de Administración Local, Biblioteca Comares de ciencia jurídica, Ed. El Consultor de los Ayuntamientos y Juzgados, Madrid, 2006.

Barrientos Grandon, Javier, "La acción de 'in rem verso' en la literatura jurídica francesa: de Pothier a 'L'Arrêt Boudier' ", Revista de Historia del Derecho Privado, núm. 3, 2000.

Calvo y Ruata, Pablo, "El contrato público de obra (con especial referencia al contrato público-administrativo de obra)", en Estudios sobre la ley de contratos del sector público, Coords. COLÁS TENAS, Jesús, y MEDINA Guerrero, Manuel, Ed. Fundación Democracia y Gobierno Local-Instituto Fernando El Católico, Madrid, 2009.

Catalá Martí, José Vicente, Manual práctico de contratación de las entidades locales, Ed. Bayer Hnos., Barcelona, 2007.

Dagorne-LabBe, Yannick, "Retour à une conception traditionnelle et extensive de l'exception de subsidiarité de l'action de in rem verso", Semaine juridique, núm. 39, 2009. 
De la Morena López, Julián, "Selección del contratista y adjudicación (X)", Contratación Administrativa Práctica, núm. 99, Julio, 2010.

De Miguel Pajuelo, Francisco, "Comentarios al artículo 31 LCSP”, en Comentarios a la Ley de Contratos del Sector Público, Dirs. Luciano Parejo Alfonso y Alberto Palomar Olmeda, Coord. Javier Vázquez Garranzo, Tomo I -Arts. 1 a 73-, Ed. Bosch, Barcelona, 2009.

De Vicente GonzÁlez, José Luis, "Enriquecimiento injusto y prestación no contratada en el ámbito de la administración local”, RAP, núm. 168, sep-dic, 2005.

Díaz Delgado, José, "Comentarios al art. 65, "Efectos de la declaración de nulidad", en AA.VV., Comentarios a la Ley de contratos de las Administraciones Públicas y a la Ley sobre procedimientos de contratación de los sectores especiales, Dir. Ricardo

García Macho, Ed. Tirant lo Blanch, Valencia, 2003.

Escrihuela Morales, Javier F., "La necesaria reforma de la modificación de los contratos públicos", Contratación administrativa práctica: revista de la contratación administrativa y de los contratistas, núm. 95, 2010, pág. 59.

Fernández de Velasco, Recaredo, Los contratos administrativos, Ed. Librería General de Victoriano Suárez, Madrid, 1927.

García de la Mata, José EnRique, "Reflexión sobre la modificación de los contratos en la Ley 30/2007, de 30 de octubre, de contratos del sector público", Diario La Ley, núm. 6983, 2008.

García Rubio, Fernando, "Procedimiento a seguir por las Administraciones Públicas en las modificaciones de los contratos de concesión de obra pública (I)", Actualidad administrativa, núm. 3, 2010, pág. 3 .

Garrido Falla, Fernando, Tratado de Derecho administrativo, Tomo II, Ed. Instituto de Estudios Políticos, 1966.

Gimenez Barriocanal, Fernando, La actividad económica en el derecho Romano: Análisis contable, Editorial Dykinson, 2003.

Gómez de la Serna, Pedro, Tratado académico-forense de procedimientos judiciales, Volumen 1, Ed. Librería de Ángel Calleja, 1848.

González-Berenguer Urrutia, José Luis, La contratación administrativa, Ed. Municipalia, Madrid, 1966.

H. Perinet-Marquet, "Le sort de l'action de in rem verso en cas de faute de l'appauvri", Semaine juridique, I, 1982.

Iglesias-Redondo, Juan, Repertorio bilingüe de definiciones, reglas y máximas jurídicas romanas, Ed. Cívitas, $1^{a}$ ed., Madrid, 1986. 
M. LeCEne-Marenaud, "Le róle de la faute dans les quasi-contrats", Revue trimestrelle de droit civil, 1994.

Martín Rebollo, Luis, "Modificación de los contratos y consecuencias patrimoniales de las modificaciones irregulares: (con especial referencia al contrato de obras)", en Comentario a la Ley de contratos de las Administraciones públicas, Coord. Rafael Gómez-Ferrer Morant, Ed. Cívitas, 2004, págs. 575-659.

Menéndez Gómez, Emilio, Contratos del Sector Público. Contrato de obras públicas, Ed. Aranzadi, 1ª ed., Cizur Menor (Navarra), 2008.

Molina Barrero, Encarnación, Such Martínez, Javier, Domech López, Juan, Regli Crivell, Carmen, "La Ley de Contratos de las Administraciones Públicas. Especial referencia a la modificación y resolución de contratos", II Seminario sobre aspectos jurídicos de la gestión universitaria: Universidad de Murcia del 11 al 13 de diciembre de 1996, 1999, págs. 479-524.

Moreno Molina, José Antonio, "La regulación comunitaria europea de las concesiones de obras públicas", en El contrato de concesión de obras públicas en la Ley de Contratos del Sector Público, Dir. Francisco Puerta Seguido, Ed. La Ley, $1^{\text {a }}$ ed., Las Rozas (Madrid), 2008.

Moreno Molina, José Antonio, y Pleite Guadamillas, Francisco, La nueva Ley de Contratos del Sector Público, 2a ed., Ed. La Ley, Las Rozas (Madrid), 2009.

Nelson Nicoliello, Diccionario del latín jurídico, Ed. Bosch, Barcelona, 1999.

Puerta Seguida, Francisco, "El contrato de concesión de obra pública La génesis de su regulación. Definición legal y objeto", en El contrato de concesión de obras públicas en la Ley de Contratos del Sector Público, Dir. Francisco Puerta Seguido, Ed. La Ley, $1^{\mathrm{a}}$ ed., Las Rozas (Madrid), 2008.

Puerta Seguido, Francisco Eusebio, Punzón Moraleda, Jesús y Domínguez Alonso, Alma Patricia, "La nueva regulación en la Directiva de la fase de ejecución de los contratos y la repercusión de la jurisprudencia del TJUE en materia de modificación de contratos", Contratación administrativa práctica: revista de la contratación administrativa y de los contratistas, núm. 129, 2014.

Punzón Moraleda, Jesús, y Sánchez Rodrñiguez, Francisco, La utilización de medios electrónicos, informáticos y telemáticos en la Ley 30/2007, de Contratos del Sector Público, Ed. La Ley, Las Rozas (Madrid), 2009.

Rebollo Puig, Manuel, "La regla nemo auditur en la jurisprudencia contenciosoadministrativa (Revista General de Derecho Administrativo, núm. 4, diciembre, 2003.

Rebollo Puig, Manuel, El enriquecimiento injusto de la Administración Pública, Ed. Marcial Pons, Madrid, 1995. 
Serrera Contreras, Pedro Luis, "Algunas cuestiones sobre responsabilidad en el contrato de concesión de obra pública", Revista Andaluza de Administración Pública, núm. 52, oct-nov-dic, 2003.

VÁzquez Matilla, Francisco JaVier, "La modificación de los contratos administrativos: reflexiones en torno a la STJCE de 29 de abril de 2004 y la Ley de Contratos del Sector Público”, REDA, núm. 2009, págs. 529-564.

Villar Ezcurra, José Luis, y Marfa Badaroux, Jaime, “Comentario al artículo 59”, en Comentarios a la Ley de Contratos de las Administraciones Públicas, Ariño y Asociados, Tomo II -La gestación del Contrato-, Ed. Comares, Granada, 2003.

Villar Palasí, Lecciones sobre contratación administrativa, Madrid, 1969. 


\section{La adjudicación de los contratos no sara* por los poderes adjudicadores que no tienen la consideración de administración pública} Francisco Puerta Seguido**

Resumen: Algunos contratos de los poderes adjudicadores que no tienen la condición de administración pública están liberados del rigor de las normas de la contratación pública y su adjudicación se lleva a cabo aplicando las llamadas "instrucciones internas" que, tal y como se expone en este capítulo, pueden regular procedimientos de adjudicación de alguno de sus contratos privados. Esto genera notables diferencias, entre unos poderes y otros, además de inseguridad jurídica, con un evidente riesgo de trato desigual y discriminatorio que ponen en cuestión los grandes principios de la contratación del sector público.

Palabras Clave: Poderes adjudicadores, instrucciones internas, principios generales de la contratación pública.

Abstract: Some contracts of contracting authorities that not have the status of public administration are released from the strictness of the rules of public procurement and their adjudication is carried out just by applying

\footnotetext{
* Esta denominación se utiliza para referirnos a los denominados contratos no sujetos a regulación armonizada.

** Profesor Doctor de la Universidad de Castilla-La Mancha, área de Derecho Administrativo de la Facultad de Ciencias Jurídicas y Sociales de Toledo. Presidente del Jurado Regional de Valoraciones de la Junta de Comunidades de Castilla-LA Mancha.
} 
the so-called "internal instructions" that, as describe in this chapter, may regulate procedures for the award of some of their private contracts. This creates considerable differences between them and other powers besides legal uncertainty, with a clear risk of unequal treatment and discrimination that call into question the great principles of public sector contracting.

Key words: Contracting authorities, internal instructions, general principles of public procurement.

\section{La delimitación, objetiva y subjetiva, de nuestro objeto de estudio}

La influencia del derecho europeo en el ordenamiento jurídico nacional supuso la incorporación de normas específicas que han conformado regímenes jurídicos distintos según esté, o no, la relación contractual sujeta a regulación armonizada. Se trata de una novedad introducida en el orden nacional por la LCSP 30/2007, de 30 de octubre, que, en su momento, no contaba con precedente normativo alguno en la legislación de Contratos de las Administraciones Públicas. La distinción concreta la transposición la Directiva 2004/18.

Antes de referirnos a ese régimen específico conviene que nos detengamos en algunas cuestiones previas pero necesarias para ser conscientes del alcance de las singularidades derivadas de esa distinción, conviene por ello enumerar los contratos que según el acervo normativo, europeo y nacional, tienen la consideración de contratos no sujetos a regulación armonizada.

La vigente ley de contratos, RDL 3/2011, de 14 de noviembre, dedica el art. 13 a delimitar en términos generales la distinción a la que nos referimos. En sus apartados $1^{\circ}$ y $2^{\circ}$ establece las reglas generales que han de seguirse para calificar un contrato como SARA o como no SARA. De conformidad con lo preceptuado han de considerarse contratos no SARA los siguientes:

1) Los enumerados en el art. 13.2, que en todo caso, cualquiera que sea su valor estimado señala el precepto, no se consideran sujetos a regulación armonizada. Se trata de los siguientes:

a) Los que tengan por objeto la compra, el desarrollo, la producción o la coproducción de programas destinados a la radiodifusión, por parte de los organismos de radiodifusión, así como los relativos al tiempo de radiodifusión.

b) Los de investigación y desarrollo remunerados íntegramente por el órgano de contratación, siempre que sus resultados no se reserven para su utilización exclusiva por éste en el ejercicio de su actividad propia ${ }^{1}$.

1 Tiene su precedente en 16.j) de la Directiva 2004/18. 
c) Los incluidos dentro del ámbito definido por el artículo 346 del Tratado de Funcionamiento de la Unión Europea que se concluyan en el sector de la defensa.

d) Los declarados secretos o reservados, o aquellos cuya ejecución deba ir acompañada de medidas de seguridad especiales conforme a la legislación vigente, o en los que lo exija la protección de intereses esenciales para la seguridad del Estado.

e) Aquellos cuyo objeto principal sea permitir a los órganos de contratación la puesta a disposición o la explotación de redes públicas de telecomunicaciones o el suministro al público de uno o más servicios de telecomunicaciones.

2. Los contratos de servicios comprendidos en las categorías 17 a 27 , ambas inclusive, y los en las categorías 1 a 16, ambas inclusive, del Anexo II de la LCSP cuando su valor estimado sea inferior al señalado en el art. 16 de la LCSP2.

3. Los contratos de obras y los de concesión de obras públicas ${ }^{3}$, los contratos de suministro ${ }^{4}$ cuando no superen las cuantías que establece la LCSP.

${ }^{2}$ El precepto dispone que "están sujetos a regulación armonizada los contratos de servicios comprendidos en las categorías 1 a 16 del Anexo II cuyo valor estimado sea igual o superior a las siguientes cantidades:

a) 134.000 euros, cuando los contratos hayan de ser adjudicados por la Administración General del Estado, sus organismos autónomos, o las Entidades Gestoras y Servicios Comunes de la Seguridad Social, sin perjuicio de lo dispuesto para ciertos contratos de la categoría 5 y para los contratos de la categoría 8 del Anexo II en la letra b) de este artículo.

b) 207.000 euros, cuando los contratos hayan de adjudicarse por entes, organismos o entidades del sector público distintos a la Administración General del Estado, sus organismos autónomos o las Entidades Gestoras y Servicios Comunes de la Seguridad Social, o cuando, aun siendo adjudicados por estos sujetos, se trate de contratos de la categoría 5 consistentes en servicios de difusión de emisiones de televisión y de radio, servicios de conexión o servicios integrados de telecomunicaciones, o contratos de la categoría 8, según se definen estas categorías en el Anexo II. 2. En el supuesto previsto en el artículo 88.7, cuando el valor acumulado de los lotes en que se divida la compra de servicios iguale o supere los importes indicados en el apartado anterior, se aplicarán las normas de la regulación armonizada a la adjudicación de cada lote. No obstante, los órganos de contratación podrán exceptuar de estas normas a los lotes cuyo valor estimado sea inferior a 80.000 euros, siempre que el importe acumulado de los lotes exceptuados no sobrepase el 20 por 100 del valor acumulado de la totalidad de los mismos.

${ }^{3}$ Para estos contratos típicos el umbral lo establece el art. 14 de la LCSP. Señala el precepto que "están sujetos a regulación armonizada los contratos de obras y los contratos de concesión de obras públicas cuyo valor estimado sea igual o superior a 5.186.000 euros.

En el supuesto previsto en el artículo 88.7, cuando el valor acumulado de los lotes en que se divida la obra iguale o supere la cantidad indicada en el apartado anterior, se aplicarán las normas de la regulación armonizada a la adjudicación de cada lote. No obstante, los órganos de contratación podrán exceptuar de estas normas a los lotes cuyo valor estimado sea inferior a un millón de euros, siempre que el importe acumulado de los lotes exceptuados no sobrepase el 20 por 100 del valor acumulado de la totalidad de los mismos.

${ }^{4}$ Para este contrato el art. 15 LCSP dispone que "están sujetos a regulación armonizada los contratos de suministro cuyo valor estimado sea igual o superior a las siguientes cantidades:

a) 134.000 euros, cuando se trate de contratos adjudicados por la Administración General 
La segunda cuestión previa que debemos abordar es la referida al ámbito subjetivo de aplicación de la LCSP, tras la importante incorporación, también por impulso comunitario, del concepto de poder adjudicador.

Como se sabe la Ley distingue, dentro de las entidades del sector público, tres categorías de sujetos que, a modo de anillos concéntricos, presentan un diferente nivel de sujeción o sometimiento a sus prescripciones:

- En primer lugar tenemos a las Administraciones Públicas 5 , considerando como tales a la Administración General del Estado, las Administraciones de las Comunidades Autónomas y las Entidades que integran la Administración Local; las entidades gestoras y los servicios comunes de la Seguridad Social; los Organismos autónomos; ${ }^{6}$ las Universidades Públicas; las entidades de derecho público que, con independencia funcional o con una especial autonomía, tengan atribuidas funciones de regulación o control de carácter externo sobre un determinado sector o actividad; las entidades de derecho público vinculadas a una o varias Administraciones Públicas o dependientes que su actividad principal no consista en la producción en régimen de mercado de bienes y servicios destinados al consumo individual o colectivo, o que efectúen operaciones de redistribución de la renta y de la riqueza nacional, en todo caso sin ánimo de lucro, o que no se financien mayoritariamente con ingresos, cualquiera que sea su naturaleza, obtenidos como contrapartida a la entrega de bienes o a la prestación de servicios; los órganos competentes del Congreso de los Diputados, del Senado, del Consejo General del Poder Judicial, del Tribunal Constitucional, del Tribunal de Cuentas, del Defensor del Pueblo, de las Asambleas Legislativas de las Comunidades Autónomas y de las instituciones autonómicas análogas al Tribunal de Cuentas y al Defensor del Pueblo, en lo que respecta a su actividad de contratación, y las Diputaciones Forales y las Juntas Generales de los Territorios Históricos del País Vasco en lo que respecta a su actividad de contratación.

del Estado, sus organismos autónomos, o las Entidades Gestoras y Servicios Comunes de la Seguridad Social. No obstante, cuando los contratos se adjudiquen por órganos de contratación que pertenezcan al sector de la defensa, este umbral solo se aplicará respecto de los contratos de suministro que tengan por objeto los productos enumerados en el anexo III.

b) 207.000 euros, cuando se trate de contratos de suministro distintos, por razón del sujeto contratante o por razón de su objeto, de los contemplados en la letra anterior.

En el supuesto previsto en el artículo 88.7 cuando el valor acumulado de los lotes en que se divida el suministro iguale o supere las cantidades indicadas en el apartado anterior, se aplicarán las normas de la regulación armonizada a la adjudicación de cada lote. No obstante, los órganos de contratación podrán exceptuar de estas normas a los lotes cuyo valor estimado sea inferior a 80.000 euros, siempre que el importe acumulado de los lotes exceptuados no sobrepase el 20 por 100 del valor acumulado de la totalidad de los mismos.

${ }_{5}^{5}$ Véase el art. 3.2 del RDL. 3/2011.

${ }^{6}$ Resulta llamativo que la LCSP no considere Administración pública a las Entidades Públicas empresariales que integran, junto a los organismos autónomos, los denominados organismos públicos. Esta exclusión se separa de las previsiones de la LOFAGE. Como también sorprende que se refiera a unos Organismos Autónomos llamados a desaparecer por su progresiva conversión, por imperativo legal, en Agencias para la mejora de los servicios públicos. 
Las Administraciones Públicas enumeradas son, en todo caso poder adjudicador ${ }^{7} \mathrm{y}$, con independencia de la cuantía del importe de los contratos, la preparación y adjudicación de los mismos se regula de forma precisa y detallada en la LCSP, en el Título I del Libro II y en el Capítulo I, del Título I del Libro III, respectivamente.

- En un segundo grupo encontramos a otros entes del sector público ${ }^{8}$ que, siendo poderes adjudicadores - art. $3.2^{9}$.b) y c)- no son Administración Pública.

Los contratos sujetos a regulación armonizada celebrados por estos poderes adjudicadores están sujetos a la LCSP, en cuanto a su preparación al artículo 137.1 LCSP, que dispone que les serán aplicables los artículos 117 en cuanto a la definición y el establecimiento de prescripciones técnicas, 118 sobre "condiciones especiales de ejecución del contrato", 119 referido a la "información sobre las obligaciones relativas a la fiscalidad, protección del medio ambiente, empleo y condiciones laborales", 120 sobre "información sobre las condiciones de subrogación en contratos de trabajo" y 112.2.b) sobre reducción de plazos por motivos de urgencia y, en cuanto a su adjudicación, se les aplican las normas establecidas para la adjudicación de los contratos de las Administraciones Públicas con las salvedades que recoge el art. 190.

\footnotetext{
${ }^{7}$ Así lo establece el art. 3.3..a) del RDL 3/2011.

8 Del art. 3 del RDL 3/2011, y concordantes, se deduce que "el sector público no administración pública" estaría integrado por las entidades públicas empresariales estatales y los organismos asimilados dependientes de las Comunidades Autónomas y Entidades locales; las sociedades mercantiles en cuyo capital social la participación, directa o indirecta, de entidades del sector público sea superior al 50 por 100; los consorcios; las fundaciones que se constituyan con una aportación mayoritaria, directa o indirecta, de una o varias entidades integradas en el sector público, o cuyo patrimonio fundacional, con un carácter de permanencia, esté formado en más de un 50 por 100 por bienes o derechos aportados o cedidos por las referidas entidades; las Mutuas de Accidentes de Trabajo y Enfermedades Profesionales de la Seguridad Social y, a modo de cajón de sastre, cualesquiera entes, organismos o entidades con personalidad jurídica propia, que hayan sido creados específicamente para satisfacer necesidades de interés general que no tengan carácter industrial o mercantil, siempre que uno o varios sujetos pertenecientes al sector público financien mayoritariamente su actividad, controlen su gestión, o nombren a más de la mitad de los miembros de su órgano de administración, dirección o vigilancia. La ley incluye en este segundo grupo de entidades integrantes del sector público a las asociaciones constituidas por los entes, organismos y entidades que hemos mencionado en este segundo grupo. De ellos sólo tendrán la condición de poderes adjudicadores los que cumplan los requisitos exigidos por el art. 3.3.b) de la LCSP.

9 Todos los demás entes, organismos o entidades con personalidad jurídica propia que, no siendo Administración pública en los términos de las LCSP, hayan sido creados específicamente para satisfacer necesidades de interés general que no tengan carácter industrial o mercantil, siempre que uno o varios sujetos que deban considerarse poder adjudicador financien mayoritariamente su actividad, controlen su gestión, o nombren a más de la mitad de los miembros de su órgano de administración, dirección o vigilancia (artículo 3.3.b). También tienen tal consideración "las asociaciones constituidas por los entes, organismos y entidades mencionados en las letras anteriores (artículo 3.3.c).
} 
Sin embargo, y aquí queremos enfatizar, en los contratos no sujetos a regulación armonizada aplicarán el art. $137.2^{10}$ en cuanto a la preparación del contrato y para la adjudicación, de acuerdo con el art. 191, aprobarán "unas instrucciones", dice el precepto, de obligado cumplimiento en el ámbito interno y que garanticen la efectividad de principios de publicidad, concurrencia, transparencia, confidencialidad, igualdad y no discriminación.

- El tercer lugar lo ocupan los entes, organismos y entidades del sector público que no son Administración Pública ni tienen la condición de poder adjudicador.

En primer lugar conviene destacar que en este supuesto carece de virtualidad la distinción entre contratos sujetos a regulación armonizada y contratos no sujetos a regulación armonizada, ya que el art. 13.3., in fine, establece que uno de los dos requisitos exigidos cumulativamente ${ }^{11}$ para caracterizar a los contratos armonizados, contratos SARA, es que la entidad contratante ostente la condición de poder adjudicador.

El art. 192 de la LCSP señala que aprobarán instrucciones internas que garantizando los principios de publicidad, concurrencia, transparencia, confidencialidad, igualdad y no discriminación, permitan la adjudicación de los contratos a la empresa que realice la oferta económicamente más ventajosa. Estas instrucciones deben ponerse a disposición de todos los interesados en participar en los procedimientos de adjudicación de sus contratos, publicarse en el perfil de contratante de la entidad y, en el ámbito del sector público estatal, deberán ser informadas antes de su aprobación por el órgano al que corresponda el asesoramiento jurídico de la correspondiente entidad.

Como puede apreciarse de nuestra exposición, el concepto clave en el estudio e interpretación de las reglas que delimitación del ámbito subjetivo de la ley es el de poder adjudicador. El artículo 1.9 de la Directiva 2004/18 establecía "son considerados poderes adjudicadores: el Estado, los entes territoriales,

${ }_{10}$ El artículo 137.2 de la LCSP, que contiene las reglas aplicables a la preparación de los contratos celebrados por poderes adjudicadores que no tengan la condición de Administraciones públicas y de los contratos subvencionados, establece que "en contratos distintos a los mencionados en el apartado anterior (ese apartado anterior se refiere a los contratos sujetos a regulación armonizada celebrados por poderes adjudicadores que no tengan el carácter de Administraciones Públicas) de cuantía superior a 50.000 euros, los poderes adjudicadores que no tengan el carácter de Administraciones Públicas deberán elaborar un pliego, en el que se establezcan las características básicas del contrato, el régimen de admisión de variantes, las modalidades de recepción de las ofertas, los criterios de adjudicación y las garantías que deberán constituir, en su caso, los licitadores sobre el adjudicatario, siendo de aplicación, así mismo, lo dispuesto en el artículo 120. Estos pliegos serán parte integrante del contrato.".

Del precepto se deduce que la obligación de elaborar un pliego con el contenido mínimo señalado en el precepto sólo es predicable de los contratos no sujetos a regulación armonizada de cuantía superior a 50.000 euros, para los de cuantía inferior esa elaboración del pliego es meramente potestativa, pues no hay prescripción legal que la imponga.

11 "Siempre que la entidad contratante tenga el carácter de poder adjudicador", dispone el precepto. 
los organismos de Derecho público y las asociaciones constituidas por uno o más de dichos entes o de dichos organismos de Derecho público. A este efecto considera organismo de Derecho público a cualquier organismo que:

a) sea creado específicamente para satisfacer necesidades de interés general que no tengan carácter industrial o mercantil,

b) esté dotado de personalidad jurídica y

c) su actividad esté mayoritariamente financiada por el Estado, los entes territoriales u otros organismos de Derecho público, o bien cuya gestión se halle sometida a un control por parte de estos últimos, o bien cuyo órgano de administración, de dirección o de vigilancia esté compuesto por miembros de los cuales más de la mitad sean nombrados por el Estado, los entes territoriales u otros organismos de Derecho público.

Como señala Gimeno $^{12}$ el principal problema interpretativo deriva del párrafo 3 de este precepto (art. 3 LCSP), al incluir la figura de poder adjudicador sin definirla claramente, ni conceptuarla como pieza esencial del sistema, lo que puede llevar a interpretaciones contradictorias sobre qué sujetos y en qué casos deben aplicar la Ley. En cualquier caso, no pretendemos en este momento profundizar sobre este extremo que trasciende la pretensión de nuestro estudio.

La nueva Directiva, la 2014/24/UE DEL PARLAMENTO EUROPEO Y DEL CONSEJO, de 26 de febrero de 2014 sobre contratación pública y por la que se deroga la Directiva 2004/18/CE, define a los Poderes adjudicadores en su artículo 2.1.1), considerando como tales al Estado, las autoridades regionales o locales, los organismos de Derecho público o las asociaciones formadas por uno o varios de dichos poderes o uno o varios de dichos organismos de Derecho público.

Conviene recordar, para cerrar esta cuestión, que los contratos no sujetos a regulación armonizada, al igual que los contratos sujetos a regulación armonizada concertados por poderes adjudicadores que no tienen la condición de Administración pública, no son contratos administrativos, sino contratos privados.

\section{EI diseño legal de la adjudicación de los contratos no sujetos a regulación armonizada por poderes adjudicadores que no son administración pública.}

Como ya se ha dicho a propósito de la delimitación objetiva y subjetiva de la contratación no armonizada, una de las principales diferencias de esta

$\overline{12}$ Gimeno Feliú, J. M.: Novedades de la ley de contratos del sector público de 30 de octubre de 2007 en la regulación de la adjudicación de los contratos públicos. Civitas - Thomson Reuters 2010, pag. 55. 
dicotomía, contratación armonizada-contratación no armonizada, reside en el régimen jurídico de la adjudicación de los contratos por parte de estos poderes adjudicadores que no tienen la consideración de Administración pública. Para los armonizados la adjudicación se lleva a cabo con sujeción a las mismas reglas que rigen para la adjudicación de los contratos de las Administraciones Públicas (Capítulo I del Título I del Libro III de la LCSP) ${ }^{13}$, sin más especialidades que las establecidas en los apartados a) y b) del artículo 190 de dicho texto legal y para los contratos no sujetos a regulación armonizada se aplicarán las previsiones contenidas en el art. 191 de la LCSP. Este último precepto, que no establece procedimiento alguno de adjudicación, dispone en su letra a) que "la adjudicación estará sometida, en todo caso, a los principios de publicidad, concurrencia, transparencia, confidencialidad, igualdad y no discriminación" y en su letra b) que "los órganos competentes de las entidades a que se refiere esta sección (poderes adjudicadores que no tengan el carácter de administraciones públicas) aprobarán unas instrucciones, de obligado cumplimiento en el ámbito interno de las mismas, en las que se regulen los procedimientos de contratación de forma que quede garantizada la efectividad de los principios enunciados en la letra anterior y que el contrato es adjudicado a quien presente la oferta económicamente más ventajosa”. Continúa el precepto señalando que "Estas instrucciones deben ponerse a disposición de todos los interesados en participar en los procedimientos de adjudicación de contratos regulados por ellas, y publicarse en el perfil de contratante de la entidad".

Las previsiones del art. 191 deben completarse con las contenidas en la disposición transitoria quinta de la ley, de manera que en tanto no se aprueben las instrucciones internas en él mencionadas, los poderes adjudicadores que no son Administración Pública se regirán por las normas y procedimientos previstos para los contratos armonizados.

El apartado 2 de esa DT 5a, atribuye la misma consecuencia para las adjudicaciones de contratos por las restantes entidades del sector público que, no siendo Administraciones públicas ni poderes adjudicadores, no hayan aprobado los manuales de instrucciones a los que se refiere el art. 192.3 de la LCSP.

Una primera aproximación al precepto debe generar una alarma justificada si se piensa en una consecuencia clara, los contratos NO SARA de los poderes adjudicadores que no tienen la condición de administración pública están liberados ex-artículo 191 del rigor y el peso de las reglas de la contratación pública y disfrutan de un régimen sui generis marcado por una evidente "deslegalización procedimental" sujetando la adjudicación de estos contratos

\footnotetext{
13 Se aplicarán, por tanto, las reglas previstas en la LCSP para el procedimiento abierto, el procedimiento restringido, el procedimiento negociado y el diálogo competitivo en los supuestos previstos para cada uno de ellos.
} 
a las previsiones contenidas en esas llamadas "instrucciones internas", ad hoc, que, tal y como ya se ha advertido, pueden regular procedimientos de adjudicación de sus contratos privados NO SARA con notables diferencias, entre unos poderes y otros, que contribuyan a generar, además de la necesaria inseguridad jurídica, las tachas o vulneraciones que siempre debemos evitar, trato desigual y discriminatorio, o bien falta de concurrencia competitiva o de transparencia, o, en fin, la aparición de barreras, la flexibilización de requisitos que de una u otra manera tambalean y ponen en cuestión los grandes principios de la contratación del sector público.

De estos peligros ya advierte GIMENO ${ }^{14}$ cuando señala que esos riesgos se incrementan por una evidente razón, "la actividad contractual realizada por los entes instrumentales no es modo alguno residual tanto por el número de entes existentes en la actualidad como por el volumen de los contratos que realizan", de manera que, continúa, "hubiera sido mejor introducir flexibilización (concursos simplificados, documentación sólo exigible al adjudicatario propuesto, etc.) pero uniforme para todos estos supuestos de descentralización funcional. Se abre, por tanto, un portillo peligroso que puede derivar en la inaplicación de hecho de la LCSP mediante la configuración, por ejemplo, de entes de derecho público que, conservando prerrogativas públicas se dotarán de un régimen «ad hoc» por debajo del umbral comunitario. Lo que, previsiblemente en la Administración local, sucederá en muchas ocasiones. A esto debe sumarse el hecho de que estas Instrucciones se publican en los específicos perfiles de contratantes, y es tal el número (de varios miles) que se dificulta -si no impide- a los licitadores tener una visión de conjunto cercenando el principio de concurrencia". A las mismas conclusiones llega la notoria Circular 1/2008, de 3 de marzo 2008, de la Junta Consultiva de Contratación Administrativa de la Comunidad Autónoma de Aragón, sobre "alcance del ámbito subjetivo de aplicación de la LCSP y régimen de contratación aplicable”, recomendando (al Gobierno) la adopción de medidas normativas que corrigieran este eventual necesario, debiendo reconsiderarse las condiciones de contratación por debajo del umbral de todo este conjunto de entes a fin de poder garantizar eficacia, concurrencia y eficiencia de fondos públicos.

\subsection{El papel clave de los principios básicos de la contratación pública.}

Esa primera aproximación al precepto, art. 191, marcada por un evidente propósito de deslegalización procedimental no es, a nuestro juicio, una caída al vacío que propugne una flexibilización extrema o descontrolada. Sigue habiendo referencias positivas que permiten la intervención de esa potestad normativa propia y sui generis que la ley atribuye a los poderes adjudicadores

${ }^{14}$ Gimeno Feliú, J.M.: Novedades de la ley... ob. cit. pág. 61, nota a pié de página $n^{\circ} 63$. 
que no tiene la consideración de administración pública en la configuración de los procedimientos de adjudicación de los contratos NO SARA.

El primer elemento de control de esa prerrogativa de aprobación de instrucciones internas reside en la necesidad de que la adjudicación esté sometida, en todo caso dice el precepto, a los principios de publicidad, concurrencia, transparencia, confidencialidad, igualdad y no discriminación. Principios que tal y como proclama el art. 1 de la LCSP constituyen el objetivo irrenunciable de la regulación, en toda su extensión, de la contratación del sector público, junto a la necesidad de asegurar, en conexión con el objetivo de estabilidad presupuestaria y control del gasto, una eficiente utilización de los fondos destinados a la realización de obras, la adquisición de bienes y la contratación de servicios mediante la exigencia de la definición previa de las necesidades a satisfacer, la salvaguarda de la libre competencia y la selección de la oferta económicamente más ventajosa.

La ausencia de regulación concreta del procedimiento de adjudicación de estos contratos y la remisión a las instrucciones internas que aprobarán los órganos competentes de los poderes adjudicadores que no son Administración pública resulta compensada, prima facie, por la necesidad de respetar escrupulosamente los principios generales de la contratación pública con todo lo que ello significa, razón por la cual nos parece conveniente recordar sumariamente el significado de esos principios que condicionan la legitimidad de esa deslegalización procedimental a la que nos estamos refiriendo.

A ese efecto debemos recordar aquí la importante, y clarificadora ${ }^{15}$, comunicación interpretativa de la Comisión Europea sobre el Derecho comunitario publicada en el Diario Oficial de la Unión Europea de 1 de agosto de 2006 (2006/CE-179/02) y referida a la adjudicación de contratos no cubiertos o sólo parcialmente cubiertos por las Directivas sobre contratación pública y aplicable, por tanto, a los contratos no sujetos a regulación armonizada por no estar comprendidos en el ámbito de aplicación de la Directiva 2004/18/CE, del Parlamento y del Consejo, de 31 de marzo de 2004.

- El primero de los principios mencionados en el art. 191.a) es el de publicidad. Principio cuya virtualidad reside en garantizar a todo licitador potencial, una publicidad adecuada que permita abrir a la competencia el mercado. El Tribunal de Justicia de las Comunidades Europeas ${ }^{16}$ vincula los

${ }^{15}$ Calificación está utilizada por Arimany Lamoglia, E. y por Navarro Manich, J.A.: “La aplicación anticipada de la delimitación del ámbito subjetivo de aplicación de la ley de contratos del sector público (Comentarios a la Disposición Transitoria Séptima de la Ley de Contratos del Sector Público”). Iustel, RGDA, n. ${ }^{\circ}$ 16, diciembre 2007, pág. 174.

16 Véanse las sentencias citadas en la propia comunicación del Tribunal de Justicia de las Comunidades Europeas de 7 de diciembre de 2000 (C-324/98) Telaustria, considerando 62; y de 
principios de igualdad de trato y de no discriminación a la imposición de una obligación de transparencia que tiene sus cimientos en esa necesidad de "garantizar, en beneficio de todo licitador, una publicidad adecuada".

Debe darse una adecuada publicidad, en consecuencia, al anuncio del contrato antes de su adjudicación.

Es necesario que ese anuncio sea suficientemente accesible dejando a la entidad adjudicadora libertad para elegir el medio más apropiado para efectuar el mencionado anuncio. A ese efecto la comunicación interpretativa de la Comisión Europea enumera y analiza incluso las diferentes posibilidades que satisfacen la exigencia de publicidad adecuada y accesible, mencionando entre los medios posibles la utilización de los siguientes:

- Internet. Del que literalmente señala que "la publicación en el sitio web de la entidad adjudicadora es un sistema flexible y con una buena relación coste-eficacia"; de manera que, dice la Comisión, "los portales Internet específicamente creados para dar publicidad a los contratos ofrecen más visibilidad y mayores posibilidades de búsqueda. A este respecto, se considera una buena práctica la creación de una plataforma específica para contratos de escasa cuantía dotada de un directorio de anuncios de contratos y de la posibilidad de suscribirse por correo-e..."

- Los Boletines oficiales nacionales, boletines nacionales especializados en la publicación de anuncios de contratos públicos, diarios de cobertura nacional o regional o publicaciones especializadas.

- Respecto de las publicaciones locales señala que "estos soportes sólo garantizan una difusión estrictamente local, pero pueden ser adecuados en determinados casos como, por ejemplo, cuando se trata de contratos de muy escasa cuantía, únicamente destinados al mercado local”.

- Menciona, en último lugar, la posibilidad de su publicación en el Diario Oficial de la Unión Europea.

De entre todos los medios mencionados, el poder adjudicador utilizará el que considere adecuado teniendo en cuenta la entidad de la contratación, atendiendo, a nuestro juicio, a elementos objetivos de la misma, como el objeto y la cuantía del contrato entre otros.

El art. 191 completa la referencia genérica al principio de publicidad con una letra c) en la que literalmente se dispone que "se entenderán cumplidas las exigencias derivadas del principio de publicidad con la inserción de la información relativa a la licitación de los contratos cuyo importe supere los 50.000 euros en el perfil del contratante de la entidad, sin perjuicio de que las instrucciones internas de contratación puedan arbitrar otras modalidades, alternativas o adicionales, de difusión."

13 de octubre de 2005 (C-458/03) Parking Brixen, considerando 49. 
La fervorosa recomendación de la Comisión en favor de la utilización del sitio web de los poderes adjudicadores para publicar los anuncios relacionados con los contratos ha tenido su eco en la legislación española y se ha traducido en la suficiencia, cuando se trata de contratos cuyo importe supere los 50.000 euros, de su publicación en el perfil de contratante de la entidad, sin perjuicio de la posibilidad de sustituir este medio por otras modalidades alternativas de difusión o de reforzarlo con otros medios adicionales para llevarla a cabo. Adviértase, por tanto, que la LCSP contempla la utilización de este concreto medio como meramente dispositiva, en la medida en que permite la sustitución de la publicación en el perfil de contratante por otros medios alternativos, además de mencionarlos también como adicionales a la misma, siempre que así se establezca en esas instrucciones internas que, también publicadas en el perfil de contratante de la entidad adjudicadora, están a disposición de todos los interesados en participar en los procedimientos de adjudicación y por tanto pueden ser por ellos conocidas.

La letra c) del art. 191 de la LCSP genera una aparente laguna al mencionar únicamente a los contratos cuyo importe supere los 50.000 euros sin hacer mención alguna a los que no cumplan con esa exigencia. El vacío normativo no puede ser aprovechado para promocionar soluciones incompatibles con los principios generales de la contratación sosteniendo que no es imperativa la publicación de contratos no armonizados de escasa cuantía ofrecidos por poderes adjudicadores que no tienen la condición de Administración pública. Como recuerda el precepto causante de la duda, la exigencia de publicidad no admite excepciones y en todo caso, como dice la letra a) del precepto, la adjudicación del contrato está sometida, entre otros, al principio de publicidad. Cabe una vez más concluir diciendo que los poderes adjudicadores deben elegir los medios adecuados, suficientes y proporcionados a la cuantía del contrato, objeto del mismo, características particulares del sector de la actividad a que se refiere (tamaño, estructura del mercado), localización geográfica, etc.

En cuanto al contenido del anuncio publicado la comunicación interpretativa que analizamos señala que "puede, por lo tanto, limitarse a una breve descripción de los detalles esenciales del contrato que debe adjudicarse y del método de adjudicación, junto con una invitación a ponerse en contacto con la entidad adjudicadora. En caso de necesidad, podría completarse con información adicional disponible en Internet o previa petición a la autoridad adjudicadora".

A nadie se le oculta que la publicidad llevada a cabo en el perfil de contratante de los Poderes adjudicadores es eficiente, tiene una buena relación coste-eficacia como dice la Comisión Europea, es un paso más en la 
incorporación de la comunicación electrónica en el ámbito de la contratación del sector público y generalmente es suficiente y accesible, pero no podemos ocultar que el número de poderes adjudicadores no administración pública y el volumen de los contratos no armonizados que por esta vía se ofertan pueden colocar a los licitadores al borde de "un verdadero ataque de nervios" ante las dimensiones de una publicidad inabarcable que les aboque a la especialización y al empleo de medios materiales y humanos afectados al objetivo de la búsqueda del contrato pretendido con dedicación casi exclusiva.

- La adjudicación de estos contratos estará sometida a los principios de igualdad y de no discriminación que, según la comunicación interpretativa que analizamos y la Jurisprudencia comunitaria, son la garantía de un procedimiento equitativo e imparcial y de ellos derivan las siguientes exigencias:

a) La necesidad de llevar a cabo una descripción no discriminatoria del objeto del contrato, evitando hacer referencia a una fabricación o procedencia determinadas o a una determinada marca o patente, o a un tipo, un origen o una producción determinados, salvo si una referencia de este tipo se justifica por el objeto del contrato y va acompañada de la mención "o equivalente".

b) La necesidad de garantizar la igualdad de acceso para los operadores económicos de todos los Estados miembros, de manera que las entidades adjudicadoras no deberán imponer ninguna condición que suponga una discriminación directa o indirecta frente a los licitadores, como, por ejemplo, la obligación de que las empresas interesadas en el contrato estén establecidas en el territorio del mismo Estado miembro o de la misma región que la entidad adjudicadora.

c) El reconocimiento mutuo de títulos, certificados y otros diplomas, aceptándose los documentos procedentes de otros Estados miembros que ofrezcan garantías equivalentes cuando se exija a los licitadores la presentación de certificados, títulos u otro tipo de documentación justificativa,

d) La imposibilidad de facilitar información que pueda proporcionar ventajas a determinados licitadores respecto del resto generando la discriminación y desigualdad proscritas.

- El principio de transparencia impone también una serie de exigencias a los poderes adjudicadores que de manera indisociable sirven para garantizar la igualdad de trato de los participantes en los procedimientos de contratación. El principio impone:

a) Que los licitadores puedan conocer previamente las normas aplicables al contrato que se pretende adjudicar, así como tener la certeza de que dichas normas se aplican de igual forma a todas las empresas. 
b) Que se fijen plazos adecuados y suficientes que permitan a las empresas realizar una evaluación de los términos de la contratación y faciliten la formulación de sus ofertas.

c) Que se vele por la seguridad jurídica fijando previamente y de manera precisa los criterios objetivos aplicables para la valoración de ofertas.

d) Que se determine de manera clara y previa el órgano al que, en su caso, le corresponde efectuar la propuesta de adjudicación y del órgano competente para la adjudicación del contrato.

e) La necesaria adjudicación del contrato a favor de la oferta económicamente más ventajosa de acuerdo con los criterios objetivos de valoración de ofertas que en cada caso se hayan establecido, tal y como recuerda también la letra b) del art. 191 como resultado necesaria de la regulación, mediante esas instrucciones internas, de un procedimiento de contratación que garantice la efectividad de los grandes principios de la contratación pública.

- El principio de confidencialidad tiene un carácter bifronte y se encuentra plasmado hoy en el art. 140 de la LCSP imponiendo la obligación de confidencialidad no sólo a los órganos de contratación sino también a los contratistas.

El apartado primero del precepto establece que "sin perjuicio de las disposiciones de la presente Ley relativas a la publicidad de la adjudicación y a la información que debe darse a los candidatos y a los licitadores, los órganos de contratación no podrán divulgar la información facilitada por los empresarios que éstos hayan designado como confidencial; este carácter afecta, en particular, a los secretos técnicos o comerciales y a los aspectos confidenciales de las ofertas".

La otra cara del principio se explicita en el apartado segundo cuando impone al contratista el deber de respetar el carácter confidencial de aquella información a la que tenga acceso con ocasión de la ejecución del contrato a la que se le hubiese dado el referido carácter en los pliegos o en el contrato, o que por su propia naturaleza deba ser tratada como tal. Termina el precepto extendiendo la obligación a un plazo de cinco años desde el conocimiento de esa información, salvo que los pliegos o el contrato establezcan un plazo mayor.

\subsection{La competencia para la aprobación de las instrucciones internas.}

El artículo 191 aborda esta cuestión con una referencia genérica consciente de la heterogeneidad de los sujetos que quedan obligados por la ley a la aprobación de las instrucciones internas reguladoras de los procedimientos de contratación en este tipo de contratos, los NO SARA. Dispone la letra b) 
del precepto que "Los órganos competentes de las entidades a que se refiere esta sección aprobarán unas instrucciones, de obligado cumplimiento en el ámbito interno de las mismas, en las que se regulen los procedimientos de contratación de forma que quede garantizada la efectividad de los principios enunciados en la letra anterior y que el contrato es adjudicado a quien presente la oferta económicamente más ventajosa".

Deben ser, por tanto, los órganos competentes de cada entidad o poder adjudicador, por atribución legal, reglamentaria, o por disposición estatutaria, teniendo en cuenta la pluralidad de formas jurídicas que pueden adoptar, los encargados de dar cumplimiento al mandato contenido en la LCSP asumiendo la tarea de aprobar esas instrucciones reguladoras de los procedimientos de contratación.

Cabe preguntarse si esa facultad o potestad normativa doméstica que la LCSP atribuye al órgano competente de cada poder adjudicador puede ser ejercida por delegación por órganos diferentes de la estructura organizativa de dichos poderes, ha de tenerse en cuenta que el cuerpo legal de referencia, la $\operatorname{LCSP}^{17}$, permite a los órganos de contratación delegar o desconcentrar sus competencias y facultades en esta materia con cumplimiento de las normas y formalidades aplicables en cada caso para la delegación o desconcentración de competencias, en el caso de que se trate de órganos administrativos, o para el otorgamiento de poderes, cuando se trate de órganos societarios o de una fundación.

Del análisis, de las disposiciones legales, reglamentarias o estatutarias que regulan la organización y el funcionamiento de los poderes adjudicadores se deduce que la competencia para la aprobación de esas instrucciones internas corresponde a los órganos que originariamente tienen atribuida esa facultad, sin que las previsiones que permiten delegar la competencia para celebrar contratos, reconocida explícitamente en el art. 51 de la LCSP y los concordantes de las normas que regulan esos poderes adjudicadores hayan previsto la facultad de delegar, también, la competencia para aprobar las denominadas "instrucciones internas". La vocación de nuestro ordenamiento jurídico no pasa, por tanto, por delegar esa función en órganos distintos y no asimila esa tarea a las facultades o poderes de gestión o administración ordinaria de los asuntos de esas entidades que sí pueden, y son delegados generalmente, en los gerentes, directores, consejeros delegados de las entidades adjudicadoras que no tienen la consideración de administración pública. Esta conclusión

17 Esta delegación o desconcentración de la competencia o facultad de contratar corresponde, asi lo establece el art. 51 de la LCSP a los órganos de contratación, unipersonales o colegiados que, en virtud de norma legal o reglamentaria o disposición estatutaria, tengan atribuida la facultad de celebrar contratos en nombre y representación de los entes, organismos y entidades del sector público. 
se ha trasladado a las propias instrucciones internas que abordan la cuestión reservando esta facultad a los órganos de la entidad que a quienes corresponde el gobierno de las mismas ${ }^{18}$. Esta parece ser, además, la solución más acorde con la solemnidad y la relevancia que nuestro ordenamiento jurídico reserva a las potestades normativas, por más que en este caso no se trate más que de unas instrucciones internas, lex contractus por otra parte, que convienen sean singularizadas y diferenciadas del resto de las facultades cuyo ejercicio requieren las operaciones contractuales.

Renunciando a la tarea de analizar los procedimientos de aprobación de las instrucciones internas atendiendo a la tipología de los poderes adjudicadores, tarea que exige el estudio de las normas singulares que los regulan, queremos dar cuenta de la obligación que pesa sobres los poderes adjudicadores no administración pública de someter las instrucciones internas aprobadas al filtro que representa el informe, previo y preceptivo, de la Abogacía del Estado $^{19}$. No coincidimos en el tratamiento de esta cuestión con opiniones ${ }^{20}$ doctrinales que atribuyen al informe previo de la Abogacía del Estado un carácter meramente potestativo o facultativo, quedando, en consecuencia, en manos del poder adjudicador la decisión de someter, o no, esas instrucciones internas al informe de la Abogacía.

El art. 191.b), in fine, impone el informe previo de la Abogacía del Estado, cuando de sector público estatal se trata, como un requisito constitutivo ${ }^{21}$, de cumplimiento necesario, cuestión distinta es que ese informe tenga carácter vinculante o no para los poderes adjudicadores que las aprueban. Lo cierto y verdad es que la LCSP no exige el carácter favorable de ese informe y no supedita la aprobación de las instrucciones internas a un pronunciamiento de la Abogacía en ese sentido, lo único que establece es la obligación, imperativa y no potestativa, de que se informe, se solicite y se emita por la Abogacía del Estado. Aún cuando se llegue a la conclusión, que nosotros promocionamos de que el informe es preceptivo y no vinculante, a nadie se le oculta que la ley

\footnotetext{
${ }^{18}$ Son la leyes reguladoras de cada tipo de entidad adjudicadora las que atribuyen esas facultades de gobierno y administración a los diferentes órganos de las mismas, los patronatos en el caso de las fundaciones, los consejos de administración en las sociedades mercantiles, la junta directivas de las asociaciones, los consejos o comités ejecutivos en los consorcios, etc

${ }_{19}$ Concluye la letra b) del art 191, in fine, exigiendo esa intervención con carácter preceptivo. Señala el precepto que "En el ámbito del sector público estatal, la aprobación de las instrucciones requerirá el informe previo de la Abogacía del Estado".

${ }^{20}$ Véase la de Mesa Vila, M.: "Instrucciones de contratación de los poderes adjudicadores que no tienen el carácter de administración pública: ¿quién las aprueba?”. Contratación Administrativa Práctica. Revista de la contratación administrativa y de los contratistas, $n^{\circ} 122$, Noviembrediciembre 2012, La Ley, Madrid 2012, pág. 77.

21 "La aprobación de las instrucciones requerirá - dice el precepto- el informe previo de la Abogacía del Estado.
} 
ha querido atribuir al mismo un peso específico que no podrá ser minimizado en ese proceso de aprobación de las instrucciones internas recurriendo a la invocación de preceptos de régimen jurídico básico, como el art. 83 de la Ley $30 / 92$, que configuran esos informes, en términos generales y cuando no haya disposición expresa en contrario, con carácter facultativo y no vinculante. En este supuesto, en particular, hay disposición en contrario, art. 191. b) de la LCSP y, para el caso de que así se entienda, la concurrencia entre las previsiones de ambas normas, ley 30/92 y LCSP, debe resolverse, por lex especialis de igual rango, a favor de la legislación sectorial.

\subsection{EI contenido de las instrucciones internas.}

El núcleo gordiano de la cuestión que nos ocupa reside en la determinación de las cuestiones y materias que deben integrar el contenido de las instrucciones internas y, por tanto, constituyen el objeto de su regulación. Poco ayuda la LCSP a la hora de afrontar esta tarea y, sin más límites que los que derivan de la garantía efectiva de los grandes principios de la contratación a los que ya nos hemos referido, la norma deja plena libertad a esos poderes adjudicadores que no tiene la consideración de administración pública para que aprueben, a medida, la regulación de los procedimientos de adjudicación de sus contratos privados no sujetos a regulación armonizada.

A juicio de la doctrina el contenido mínimo de esas Instrucciones internas debería regular las siguientes cuestiones:

a) La determinación de los órganos responsables de la adjudicación del contrato. Atendiendo a las reglas de organización de cada uno de los poderes adjudicadores se atribuye esta facultad a unos u otros órganos en función del tipo de contrato y/o de la cuantía del mismo. Es frecuente que el órgano de contratación esté asistido por un órgano de valoración encargado de calificar la documentación presentada, recabar los informes técnicos que estime oportunos, valorar las ofertas y elevar una propuesta de adjudicación al órgano de contratación. Resulta conveniente la designación genérica de los integrantes de esos órganos de asistencia para garantizar la transparencia del procedimiento. Suelen ser los responsables del asesoramiento jurídico y el control económico de esos poderes adjudicadores.

b) Se han de regular las condiciones de aptitud de los licitadores de conformidad con las previsiones generales que sobre capacidad, solvencia y prohibiciones de contratar establece la LCSP. El art. $65.5^{22}$ configura como potestativa la exigencia de una determinada clasificación a los licitadores y el 74.3 permite que para los contratos que no estén sujetos a regulación

22 El precepto dispone que "Las entidades del sector público que no tengan el carácter de Administración Pública podrán exigir una determinada clasificación a los licitadores para definir las condiciones de solvencia requeridas para celebrar el correspondiente contrato". 
armonizada los entes, organismos y entidades del sector público que no tengan la condición de Administraciones Públicas puedan admitir otros medios de prueba de la solvencia distintos de los previstos en los artículos 75 a 79 .

c) Deben regularse los procedimientos de adjudicación de manera que se garantice, como ya se ha dicho, la efectividad de los principios básicos de la contratación antes mencionados y que el contrato se adjudique a quien presente la oferta económicamente más ventajosa.

En este ámbito, el de la regulación del procedimiento de adjudicación, es donde mayor intensidad tiene esa técnica deslegalizadora que se lleva a cabo por medio de las instrucciones internas de contratación fomentando la iniciativa de los poderes adjudicadores. La doctrina ${ }^{23}$ ha recomendado el uso de terminología distinta a la utilizada en la propia LCSP para evitar confusiones que generen inseguridad jurídica.

Las instrucciones internas ${ }^{24}$ suelen distinguir, en función de las cuantías de los contratos, entre un procedimiento general aplicable a los contratos de valor estimado superior a $100.000 €$ o a $1.000 .000 €$ en el caso de obras (IVA excluido) y de un procedimiento simplificado para contratos de cuantía inferior a esos umbrales, en otras instrucciones se denominan procedimiento abierto y procedimiento negociado.

Resulta muy conveniente la aprobación en esas instrucciones internas de una regulación precisa y detallada de las fases y trámites integrantes del procedimiento de adjudicación y de las reglas del cómputo de los plazos previstos para cada uno de ellos: presentación de ofertas, de subsanación de la documentación, de valoración y elevación de la propuesta de adjudicación, plazo máximo para la adjudicación. De especial interés la regulación de los plazos en una contratación que, como ya se sabe, tiene carácter privado.

d) Ha de regularse la formalización de los contratos y los medios que deben utilizarse para dar publicidad a la información relativa a la licitación, especialmente para aquellos contratos que no alcanzan el umbral de los 50.000 euros exigidos por el art. 191.c) y para los que, en consecuencia, no rige la obligación de su publicación en el perfil del contratante o en otros medios alternativos. Por las razones que ya se han expuesto para este tipo de contratos también parece que la publicación en ese perfil de contratante de la entidad sigue siendo el medio más adecuado para dar efectividad a ese principio de publicidad.

e) Finalmente se incluyen previsiones destinadas a determinar el orden jurisdiccional competente y que sirven para recordar que las cuestiones litigiosas relativas a la preparación y adjudicación de los contratos será el contencioso-administrativo, en el caso de contratos sujetos a regulación armonizada, y el civil, en el caso de contratos no sujetos a regulación armonizada. Para resolver las controversias que surjan entre las partes en

${ }^{23}$ Gimeno Feliú, J.M.: Novedades de la ley.... ob. cit. pág . 63.

${ }^{24}$ Véase, por ejemplo, el modelo unificado de instrucciones internas para poderes adjudicadores no administración pública publicado en el portal de contratación de la Junta de Comunidades de Castilla-La Mancha. 
relación con los efectos, cumplimiento y extinción de todos los contratos, ya estén sujetos a regulación armonizada o no, será competente el orden jurisdiccional civil. 


\section{REFERENCIAS}

Alonso Higuera, Carmen, "Ley de contratos del sector público: ámbito de aplicación. Modalidades contractuales y régimen de invalidez de los procedimientos de contratación", en Estudios sobre la Ley de contratos del sector público, Coord. Jesús Colás Tenas y Manuel Medina Guerrero, Ed. Fundación Democracia y Gobierno Local-Institución Fernando El Católico, Madrid, 2009.

Ariño Sánchez, Rafael y Sastre Beceiro, Mónica, "Comentario al artículo 101", en Comentarios a la Ley de Contratos de las Administraciones Públicas, Ariño y Asociados, Tomo III -La gestión del Contrato-, Ed. Comares, Granada, 2005.

Arimany Lamoglia, E. y por NAVArRo Manich, J.A.: "La aplicación anticipada de la delimitación del ámbito subjetivo de aplicación de la ley de contratos del sector público (Comentarios a la Disposición Transitoria Séptima de la Ley de Contratos del Sector Público"). Iustel, RGDA, n. ${ }^{\circ}$ 16, diciembre 2007.

Catalá Martí, José Vicente, Manual práctico de contratación de las entidades locales, Ed. Bayer Hnos., Barcelona, 2007.

Escrihuela Morales, Javier F., "La necesaria reforma de la modificación de los contratos públicos", Contratación administrativa práctica: revista de la contratación administrativa y de los contratistas, núm. 95, 2010, pág. 59.

Fernández de Velasco, Recaredo, Los contratos administrativos, Ed. Librería General de Victoriano Suárez, Madrid, 1927.

García de la Mata, José Enrique, "Reflexión sobre la modificación de los contratos en la Ley 30/2007, de 30 de octubre, de contratos del sector público", Diario La Ley, núm. 6983, 2008.

Gimeno Feliú, J. M.: Novedades de la ley de contratos del sector público de 30 de octubre de 2007 en la regulación de la adjudicación de los contratos públicos. Civitas - Thomson Reuters 2010.

Menéndez Gómez, Emilio, Contratos del Sector Público. Contrato de obras públicas, Ed. Aranzadi, 1a ed., Cizur Menor (Navarra), 2008.

Mesa Vila, M.: "Instrucciones de contratación de los poderes adjudicadores que no tienen el carácter de administración pública: ¿quién las aprueba?”. Contratación Administrativa Práctica. Revista de la contratación administrativa y de los contratistas, $n^{\circ} 122$, Noviembre-diciembre 2012, La Ley, Madrid 2012.

Moreno Molina, José Antonio, y Pleite Guadamilla, Francisco, La nueva Ley de Contratos del Sector Público, 2a ed., Ed. La Ley, Las Rozas (Madrid), 2009. 
Puerta Seguido, Francisco, "El contrato de concesión de obra pública. La génesis de su regulación. Definición legal y objeto", en El contrato de concesión de obras públicas en la Ley de Contratos del Sector Público, Dir. Francisco Puerta Seguido, Ed. La Ley, 1ª ed., Las Rozas (Madrid), 2008.

Puerta Seguido, Francisco Eusebio, Punzón Moraleda, Jesús y Domínguez Alonso, Alma Patricia, "La nueva regulación en la Directiva de la fase de ejecución de los contratos y la repercusión de la jurisprudencia del TJUE en materia de modificación de contratos", Contratación administrativa práctica: revista de la contratación administrativa y de los contratistas, núm. 129, 2014.

Punzón Moraleda, Jesús, y Sánchez Rodríguez, Francisco, La utilización de medios electrónicos, informáticos y telemáticos en la Ley 30/2007, de Contratos del Sector Público, Ed. La Ley, Las Rozas (Madrid), 2009. 



\title{
Las competencias de los entes locales en materia de turismo tras la reforma del régimen local español
}

\author{
Antonio Villanueva Cuevas *
}

Resumen: El régimen local español ha sufrido recientemente una profunda reforma a través de la Ley 27/2013 de 27 de diciembre, de racionalización y sostenibilidad de la Administración Local, que ha intentado articular, entre otras cuestiones, un nuevo esquema competencial para municipios y provincias. Una de las materias que se ha visto afectada por dicha reforma ha sido el turismo, cuyo contenido se ha concretado, y en nuestra opinión, reducido. Los entes locales, sin embargo, poseen un interés relevante en el sector turístico, tanto por los ingresos económicos que les reporta como por ser la Administración Pública más cercana a los ciudadanos, y por ello, también a los turistas. En este sentido, varias leyes autonómicas de ordenación del turismo han atribuido competencias a municipios y provincias que exceden el reducido contenido previsto en la ley básica estatal, lo que genera problemas de coordinación entre ambas normativas.

Palabras clave: turismo, régimen local, municipios, provincias, competencias.

Abstract: The Spanis Law of Local Government has been modified by the Law 27/2013, of december 27, about rationalization and sustainability of the Local Government. This Law elaborates a new system of powers for munici-

* Profesor Ayudante, Doctor (TUA), Universidad de Castilla-La Mancha. 
palities and counties, and the powers about tourism han been reduced. But the municipalities and the counties have a relevant interest about tourism, so much as economic sector as for there relationship with the tourists. For it, several touristic laws of diferents Autonomous Regions have provided in their contents municipal and provincial powers that exceed the limited content of the statal Law. This matter causes coordination problems between both regulations.

Key words: tourism, Local Government, municipalities, counties, local powers.

\section{La intervención de los entes locales en materia de turismo hasta la reforma introducida por la Ley 27/2013, de 27 de diciembre, de Raciona- lización y Sostenibilidad de la Administración Local (LRSAL)}

El papel que poseen los entes locales en un adecuado desarrollo del turismo es ciertamente relevante. No podemos olvidar que son la Administración más cercana a los ciudadanos, y por tanto, también a los turistas, que demandan servicios y prestaciones que en muchas ocasiones deben ser implementados por aquellos, y además, con unos niveles de calidad adecuados. Por otro lado, los recursos económicos que muchos municipios perciben a través del turismo suponen, en numerosas ocasiones, la principal fuente de ingresos de los mismos, proporcionando empleo, además, a la mayoría de su población. En definitiva, el turismo es una materia sobre la cual los entes locales tienen que poseer una cierta capacidad de intervención, y tanto el Estado como las Comunidades Autónomas deben tomar en consideración a aquellos en el momento de adoptar decisiones que afecten al sector turístico.

Sin remontarnos a antecedentes históricos remotos, para lo cual nos remitimos a otros estudios previos ${ }^{1}$, la intervención de los entes locales en materia de turismo ha sufrido vaivenes de acuerdo con las corrientes centralizadoras o descentralizadoras que, como criterio general de actuación pública, ha impregnado el funcionamiento de las Administraciones Públicas españolas.

En este sentido, se puede decir que la intervención municipal en materia de turismo había sido ciertamente relevante durante la primera mitad del siglo

\footnotetext{
${ }^{1}$ Entre otros muchos, podemos ver: Fernández Álvarez, J.: Curso de Derecho Administrativo Turístico. Ed. Nacional. Madrid. 1974. Tomo I. Pg. 3 y ss.; Fernández Fuster, L.: Historia general del turismo de masas. Madrid, 1991; Martín Mateo, R., Martín-Retortillo, L., y Villar Palasí, J.L: “Aspectos jurídico administrativos del turismo". Ponencia presentada en el Primer Congreso Italo-Español de Profesores de Derecho Administrativo posteriormente incluida en un volumen publicado por el Ministerio de Información y Turismo. Madrid. 1970. Pg. 31 y ss.; Roca Roca, E., Ceballos Martín, Mª M., y Pérez Guerra, R.: La regulación jurídica del turismo en España. Servicio de Publicaciones de la Universidad de Almería. Almería. 1988. pg. 21 y ss; Villanueva Cuevas, A..: El turismo como ámbito de intervención administrativa: desde la parcialidad a la globalidad. Ed. Alfonsípolis, Cuenca, 2012, pgs. 39 y ss.
} 
XX, en un principio vinculada a las políticas públicas en materia de sanidad y seguridad ${ }^{2}$. Incluso, ya en 1935, se atribuyen a los municipios facultades estrictamente turísticas, al entender que son competencias de aquéllos el "fomento del turismo, protección y defensa del paisaje, museos, monumentos artísticos e históricos, playas y balnearios" (artículo 101, letra h, de la Ley municipal de 31 de octubre de 1935) ${ }^{3}$. Tales competencias serán desarrolladas en la Ley de Régimen Local de 16 de diciembre de 1950, en su artículo 101, apartado 2, letra j), la cual atribuyó competencias para el fomento del turismo -entre otras- tanto a municipios como a provincias.

Sin embargo, precisamente hacia la mitad del siglo $\mathrm{XX}$ van a confluir algunos elementos que modificarán sustancialmente este esquema que venimos describiendo: por un lado, en la década de los 50 del citado siglo, se inicia en España un desarrollo turístico muy importante, debido a diferentes factores (devaluación de la peseta -lo que originó que España fuera destino turístico barato-, ligera apertura al exterior del régimen político existente en dicha época,... $)^{4}$, y que conllevará que, en las décadas siguientes, el turismo español se considere uno de los sectores productivos más importantes -sino el que más- del país y que España llegue a ser uno de los principales destinos turísticos mundiales . Por otro lado, en esa época la Administración española estaba sufriendo un proceso de centralización competencial que conllevó, como ha indicado la doctrina más autorizada, un vaciamiento de competencias locales a favor del Estado ${ }^{5}$ y al que no fueron ajenas las competencias municipales y provinciales en materia de turismo ${ }^{6}$.

Como es fácil imaginar, la relevancia que el sector turístico estaba adquiriendo para la economía nacional, junto a esa corriente centralizadora, originó que la legislación sectorial apenas reconociera facultades a los entes locales en esta materia, y además, que se utilizara a los órganos de la Administración periférica del Estado, como las delegaciones provinciales de turismo o los gobernadores civiles, para la ejecución a nivel local de las competencias atribuidas al Estado, en detrimento de la Administración local, lo que conllevó que el papel de los entes locales en esta materia pasara a ser, durante este periodo, francamente escaso ${ }^{7}$, y que las competencias atribuidas a los mismos en su legislación reguladora -a la que antes hemos hecho referencia- tuvieran un valor puramente formal.

${ }^{2}$ Martín Mateo, R., Martín-Retortillo, L., y Villar Palasí, J.L. Op. cit.. Pg. 34.

${ }^{3}$ Roca Roca, E., y Pérez Martos, J.: “Administración municipal y turismo”. XI Congreso Italo-Español de Profesores de Derecho Administrativo. Cedecs Editorial. Barcelona. 1998. Pgs. 22 y 23 , de donde se han extraídos los datos incluidos en el texto.

${ }^{4}$ Al respecto, Cals, J: Turismo y política turística española. Ed. Ariel. Barcelona. 1984

${ }^{5}$ García de Enterría, E.: Estudios sobre autonomías territoriales. Ed. Cívitas. Madrid. 1985.

${ }^{6}$ Martín Mateo, R., Martín-Retortillo, L., y Villar Palasí, J.L. Op. cit., Pg. 41. También Bermejo Vera, J.: "Administración Pública y turismo". REVL. No 223. Julio-septiembre. 1984. Pg. 217 y ss.

${ }^{7}$ Fernández Álvarez, J., Op. cit., pg. 136. 
Esta situación se va a mantener hasta la aprobación de la Constitución española de 1978 y la modificación radical del régimen jurídico existente en España que la misma conlleva. Al margen de otros muchos aspectos, y ciñéndonos exclusivamente a lo que nosotros interesa, la Norma Fundamental va a crear un nuevo modelo de distribución territorial del poder que se denomina Estado autonómico, y que se caracteriza por el reconocimiento de un grado elevado de elevado de autonomía política, pero también legislativa, financiera, y desde luego, de gestión administrativa a los diversos territorios y regiones que componen España.

Precisamente, el turismo se va a convertir en una de las materias que las Comunidades Autónomas pudieron asumir en sus Estatutos de Autonomía desde el mismo momento de la aprobación de éstos, según indica el artículo 148.1, apartado 18, de la Constitución, y así lo realizaron todas ellas en su momento, de manera que, actualmente, la materia turismo es de competencia prácticamente exclusiva de las Comunidades Autónomas, mientras que el Estado solamente posee de manera residual algunas competencias turísticas - por ejemplo, Paradores Nacionales ${ }^{8}$, si bien sí que tiene capacidad de intervenir en el sector turístico de manera indirecta mediante el ejercicio de otros títulos competenciales a él atribuidos, como bases y coordinación de la planificación general de la actividad económica, comercio exterior o relaciones internacionales, aunque en estos supuestos siempre hay que tener en consideración que el Estado no puede utilizar dichos títulos para vaciar de contenido las competencias autonómicas, como ha puesto de relieve el Tribunal Constitucional en diversas sentencias.

Pero, además, la Constitución también reconoce autonomía, con un carácter diferente al de las Comunidades Autónomas, a los entes locales, que se traduce, a grandes rasgos, en la capacidad de intervenir en todos los asuntos que sean de su interés ${ }^{9}$, y que, en principio, debería conllevar un incremento sustancial del ámbito de intervención de aquéllos en materia de turismo. En este sentido, los artículos 140 y 141 de aquella Norma garantizan la autonomía local para municipios y provincias que, como también ha destacado el Tribunal Constitucional en su sentencia 31/1981, de 28 de julio de 1981, debe ser entendida "como un derecho de la comunidad local a la participación, a través de órganos propios, en el gobierno y administración de cuantos asuntos le atañen”.

En desarrollo de esa previsión constitucional, fue aprobada la Ley Reguladora de las Bases de Régimen Local, de 2 de abril de 1985 -en adelante,

${ }^{8}$ Lo que no ha dejado de generar polémica, todavía no resuelta, por ejemplo, ver Mir Bagó, J: Comentarios sobre el Estatuto de Autonomía de Cataluña. Institu d'Estudis Autonòmics. Barcelona. 1990. Pgs. 626-627.

${ }^{9}$ A este respecto, por todos, ver Ortega Álvarez, L: El régimen constitucional de las competencias locales. INAP. Madrid. 1988. 
LRBRL-, recientemente modificada, en cuyo artículo 25, apartado 2, en su anterior redacción, recogía un amplio elenco de materias sobre las cuales los municipios, en todo caso, debían poseer competencias en los términos de la legislación estatal y autonómica, y en su letra $\mathrm{m}$ ) se aludía, sin más restricción, al "turismo", por lo cual, aquéllos, en cumplimiento de dicha Ley, debían poseer competencias propias específicas en dicha materia.

Esta realidad, además, se completaba con las competencias que dicho precepto atribuía a los municipios en otras materias, no específicamente turísticas, pero cuya vinculación con el turismo es innegable, hasta el punto de que las decisiones públicas adoptadas sobre las mismas pueden derivar en importantes consecuencias para el desarrollo del turismo local, por ejemplo, y sin ánimo exhaustivo, seguridad en lugares públicos (letra a), ordenación del tráfico de vehículos y personas en las vías urbanas (letra b), ordenación, gestión, ejecución y disciplina urbanística, parques y jardines, pavimentación de vías públicas urbanas y conservación de caminos y vías rurales (letra d), patrimonio histórico artístico (letra e), protección del medio ambiente (letra f), ferias y defensa de usuarios y consumidores (letra g), suministro de agua y alumbrado público, servicios de limpieza viaria, de recogida y tratamiento de residuos, alcantarillado y tratamiento de aguas residuales (letra 1), transporte público de viajeros (letra 11), actividades o instalaciones culturales y deportivas, ocupación del tiempo libre (letra $\mathrm{m}$ ), así como con los servicios públicos de prestación obligatoria por los municipios, enumerados en el artículo 26 de dicha ley -también en su antigua redacción-, por ejemplo, el alumbrado público, recogida de residuos, limpieza viaria, abastecimiento domiciliario de agua potable, alcantarillado, acceso a los núcleos de población, pavimentación de las vías públicas, e incluso, el control de alimentos y bebidas, cuya relación con el desarrollo turístico de un municipio también es innegable.

Al margen de tales competencias, que ya hemos comentado son calificadas como propias de los municipios atendiendo a su autonomía local, éstos también podrían incidir en el sector turístico a través de las llamadas competencias delegadas, bien del Estado, bien de las Comunidades Autónomas, y de las actividades complementarias a las de estas Administraciones Públicas, si bien tanto en un caso como en otro el régimen jurídico de tales competencias es diferente, y mucho más limitado, al de las propias.

Muy diferente era, sin embargo, la función que se les atribuía a las Provincias en materia de turismo, pues la anterior redacción de la LRBRL reservaba a su órgano de gobierno, las Diputaciones Provinciales, una actuación básicamente de apoyo, colaboración y asistencia a los municipios en el ejercicio de sus competencias ${ }^{10}$, de manera que, en relación al

${ }^{10}$ Al respecto ver, por todos, Parejo Alfonso, L., Jiménez-Blanco, A., y Ortega Álvarez, L: Ma- 
turismo, y al margen de esa función de asistencia municipal que se acaba de referir -ciertamente importante, por otro lado-, sólo se podía destacar una competencia que poseía una gran relevancia para el sector turístico provincial, en cuanto que la antigua letra d), del artículo 36.1 de la LRBRL, indicaba que era una competencia propia de las Diputaciones, "en general, el fomento y la administración de los intereses peculiares de la Provincia”, a través de la cual se posibilitaban una pluralidad de actividades de aquellas en orden a la promoción y fomento de la riqueza turística de la provincia.

Atendiendo a las competencias autonómicas sobre turismo, y a las posibilidades que sobre dicha materia permitía la antigua redacción de la LRBR1 a municipios y provincias, se podía interpretar que la intervención que los mismos debían poseer en dicha materia era ciertamente relevante. Sin embargo, la realidad no fue así. En primer lugar, son escasas las Comunidades Autónomas que reconocen en sus Estatutos de Autonomía competencias a los entes locales en materia de turismo, por ejemplo, Andalucía, a través del artículo 92.1, letra K, de su Estatuto, se refiere a "la promoción del turismo", y Cataluña, cuya la Ley 6/2006 de 19 de julio, de reforma del Estatuto catalán, recoge en su artículo 84.2, letra i), "la regulación del establecimiento de autorizaciones de todo tipo de actividades económicas, especialmente las de carácter comercial, artesanal y turístico..."11.

En todo caso, esta ausencia no sería especialmente relevante si la legislación sectorial de las Comunidades Autónomas, en desarrollo de sus competencias sobre esta materia, hubiera atribuido a sus entes locales facultades sobre la misma, pues la concreción de las competencias propias de éstos en dicha materia se debe hacer en los términos de la legislación estatal y autonómica, como ya dijimos en su momento.

$\mathrm{Y}$ a este respecto, ya podemos adelantar que existen abultadas diferencias entre Comunidades Autónomas. Por un lado, encontramos varias Comunidades Autónomas que en sus leyes turísticas dedican algún precepto a enumerar las competencias en la materia de dichos entes, en concreto, Andalucía (Ley 13/2011, de 23 de diciembre), Castilla y Léon (Ley 14/2010, de 9 de diciembre), Canarias (Ley 7/1995, de 6 de abril, de Ordenación del Turismo), Asturias (Ley 7/2001, de 22 de junio, de Turismo), Aragón (Decreto Legislativo 1/2013, que aprueba el Texto Refundido de la Ley de Turismo), Cataluña (Ley 13/2002, de 21 de junio, de Turismo), Galicia (Ley 7/2011, de 27 de octubre, de Turismo), Navarra (artículo 6 de la Ley Foral 7/2003, de 14 de febrero, de Turismo), Baleares (artículos 7 y 8 de la Ley 8/2012, de 19 de julio, de

nual de Derecho Administrativo (3 ${ }^{a}$ edición). Ed. Ariel, Barcelona, 1994.

${ }_{11}$ Declarado constitucional por la STC 31/2010, de 28 de junio, sobre reforma del Estatuto catalán, FJ 37. 
Turismo), Extremadura (artículos 5 y 6 de la L ey 2/2011, de 31 de enero, de desarrollo y modernización del Turismo), y Murcia (artículo 6 de la Ley 12/2013, de 20 de diciembre, de Turismo).

Alguna otra, como el País Vasco, les atribuyen algunas facultades, ciertamente escasas, en el momento de regular más detalladamente diversos aspectos del sector turístico, y así, por ejemplo, el artículo 53 de la Ley Vasca de Ordenación del Turismo, destinado a delimitar la competencia en materia de promoción turística, indica que "corresponde a los municipios la promoción de su oferta turística con arreglo a la normativa vigente" (apartado 2), mientras que también existen ciertas Comunidades Autónomas que no recogen mención a las competencias locales, como Castilla-La Mancha o Madrid.

Estudiemos, por tanto, más detenidamente cuales son las facultades que dichas leyes autonómicas han atribuido a los entes locales en materia de turismo.

\section{A. Las competencias en materia de turismo atribuidas a los municipios en la legislación autonómica}

Ciertamente, la legislación autonómica que acabamos de enumerar reconoce facultades a los municipios en materia de turismo de manera muy diversa, y sin perjuicio de que alguna Comunidad Autónoma sea más escueta que el resto, como Andalucía, que remite al artículo 9.16 de su Ley 5/2010 de 11 de junio, de Autonomía Local, donde se alude a la promoción del turismo local, que incluye sus recursos turísticos y fiestas de especial interés, la participación en la formulación de los instrumentos de planificación y promoción turísticas de Andalucía y el diseño de la política de infraestructuras de titularidad local (y al margen de cualquier otra que pueda ser delegada o transferida por la Junta de Andalucía), podemos apreciar como otras Comunidades Autónomas, junto a las anteriores competencias, también se refieren a la protección y conservación de sus recursos turísticos y a la adopción de las medidas necesarias para su utilización y disfrute (por ejemplo, Extremadura, Castilla y León o Asturias), a la intervención que les atribuya la legislación en materia turística, bien a través de las oportunas licencias o de declaraciones responsables (entre otras, Canarias, Asturias, Cataluña, Extremadura o Aragón), a la aprobación de planes de desarrollo turístico de ámbito municipal (por ejemplo, Castilla y León o Baleares), a la declaración de recursos turísticos de interés local, y en su caso, la iniciativa para que sean declarados recursos turísticos esenciales (por ejemplo, Cataluña), a la potenciación y promoción de geodestinos turísticos (por ejemplo, Galicia) o al ejercicio de la función inspectora sobre las actividades turísticas en su ámbito territorial (Cataluña), entre otras.

Como se puede apreciar fácilmente, la intervención que dichas normas reservan a los municipios es bastante más intensa que las facultades tradicionales de promoción de sus recursos turísticos o de gestión de sus oficinas de 
información turística, alcanzando a la protección de sus recursos, el otorgamiento de licencias, la planificación de su desarrollo turísticos, e incluso, la inspección, entre otros aspectos, y ello, como veremos posteriormente, tiene un difícil acomodo con las competencias que legislación básica de régimen local reserva a los municipios tras su reciente reforma.

\section{B. Las competencias en materia de turismo de las provincias y otros entes supramunicipales en la legislación autonómica}

Además de a los municipios, algunas de las normas autonómicas antes citadas también atribuyen competencias en materia de turismo a las provincias y a otros entes locales de ámbito territorial superior al municipio, como las comarcas, y al igual que en el supuesto anterior, también de manera muy diversa entre ellas.

De esta manera, a las Diputaciones provinciales se les reconocen facultades de promoción turística de su ámbito territorial, desarrollo de la política de infraestructuras turísticas de la provincia, asesoramiento técnico a los municipios en esta materia, aprobación de los planes de desarrollo turístico provincial (Castilla y Léon, Extremadura, Canarias -en este caso, referidas a los Cabildos Insulares-, Cataluña), pero incluso el ejercicio de la potestad reglamentaria en materia turística dentro de su ámbito competencial así como la inspección y sanción en los términos que establezca la ley (Baleares, también referido a sus Cabildos Insulares).

En lo referido a las comarcas, el hecho de que éstas sean un ente local de ámbito territorial superior al municipio que se caracteriza porque supone la agrupación de municipios con características sociales, culturales, económicas, geográficas,..., y por tanto, turísticas, comunes, ha originado que hayan sido varias las normas autonómicas de ordenación del sector que han considerado que las mismas pueden ser un instrumento distintivo para resaltar la riqueza y variedad en todos esos aspectos de un territorio. No obstante, y al margen de la tradicional importancia que la comarcalización tiene en algunas Comunidades Autónomas, como Cataluña o Aragón, son todavía escasas las que consideran a las comarcas como un instrumento eficaz para la promoción y fomento del turismo.

De esa manera, algunas de las normas autonómicas de regulación del turismo atribuyen a las mismas facultades de promoción turística, coordinación de las acciones de promoción y fomento del turismo de los municipios de su ámbito territorial, aprobación de planes de desarrollo turístico comarcal, la declaración de recursos turísticos de interés para la comarca, la gestión de las oficinas comarcales de turismo (Castilla y León, Cataluña, Aragón), pero también el ejercicio de las potestades autorizatoria, registral, inspectora y disciplinaria sobre empresas y establecimientos turísticos (Aragón). 
En todo caso, la reciente reforma del régimen local español también ha supuesto una modificación en el papel que hasta ahora venían desempeñando las Diputaciones Provinciales en dicho régimen local, lo que, como seguidamente veremos, también afecta a sus facultades en materia de turismo y hará que nos detengamos en ellas de manera detallada.

\section{El turismo como ámbito de intervención local tras la reforma realizada por la LRSAL}

El régimen local español ha sufrido recientemente una de sus modificaciones más relevantes tras la aprobación de la Ley 27/2013 de 27 de diciembre, de Racionalización y Sostenibilidad de la Administración Local, que modifica la Ley 7/1985 de 2 de abril, reguladora de las Bases de Régimen Local, y que, salvo alguna revisión más o menos puntual, se había mantenido casi inalterada hasta nuestros días ${ }^{12}$.

Ciertamente, la aplicación a la Administración local de los principios de estabilidad presupuestaria y sostenibilidad financiera, en un ambiente de crisis económica global, serán las razones justificativas de tal reforma ${ }^{13}$. La necesidad de aligerar el volumen de las Administraciones Públicas, reclamado desde diferentes ámbitos de la sociedad, desembocará en la aprobación de una ley que no ha dejado de tener críticas desde su primera redacción por entender que, si bien la reforma del régimen local español era necesaria, la misma requiere un proceso bien pensado, con vocación de perdurabilidad, y no ser

\footnotetext{
12 Además de la Ley de Bases de 1985, la LRSAL también modifica el Real Decreto Legislativo 2/2004, de 5 de marzo, que aprueba el Texto Refundido de la Ley de Haciendas Locales, y escasamente, también la Ley 30/1992, de 26 de noviembre, de Régimen Jurídico de las Administraciones Públicas y Procedimiento Administrativo Común.

${ }^{13}$ Las creaciones científicas sobre la LRSAL han sido muy numerosas, entre otros: Almeida Cerreceda, M., "La reforma de la planta, organización, articulación y estructura competencia de la Administración Local", ponencia presentada en el VIII Congreso de la Asociación Española de Profesores de Derecho Administrativo, celebrado en Alicante los días 8 y 9 de febrero de 2013, disponible en la pg. web de la AEPDA; Boix Palop, A., "Tres notas explicativas sobre el sentido y orientación de la Ley 27/2013, de racionalización y sostenibilidad de la Administración local: limitación de la autonomía local, recentralización y redefinición de los mercados de servicios locales". Diario del Derecho municipal., Iustel. Tres de enero de 2014; Castillo Blanco, F., "Una lectura de urgencia de la Ley 27/2013, de 27 de diciembre, de racionalización y sostenibilidad de la Administración local". Diario del Derecho municipal. Iustel. Tres de enero de 2014; Domingo Zaballos, M.J. (Coord.): Reforma del Régimen Local. La Ley de Racionalización y Sostenibilidad de la Administración Local: Veintitrés Estudios. Ed. Thomson Reuters-Aranzadi. Cizur Menor (Navarra). 2014; Mellado Ruiz, L.: "Notas críticas sobre el Anteproyecto de ley para la racionalización y sostenibilidad de la Administración local, entre la reforma y la intervención". Revista CEMCI. N N 17. 2012; Nogueira López, A., "Crisis económica y cambios estructurales en el régimen del ejercicio de actividades". En El Derecho Público de la crisis económica. Transparencia y sector público. Hacia un nuevo Derecho Administrativo. Actas del VI Congreso de la AEPDA. INAP. Madrid. 2012.
} 
realizado al hilo de una presunta reducción del déficit público, basado en razones puramente coyunturales, y que pueden generar, en un futuro, problemas de difícil solución ${ }^{14}$.

Sin profundizar en tales críticas, lo cierto es que, por lo que a nosotros interesa en este momento, la LRSAL va a afectar de manera esencial al régimen de competencias que poseen los municipios y las provincias, limitando las facultades que los primeros ostentaban antes de la aprobación de la misma $\mathrm{y}$, curiosamente, otorgando mayores competencias a las segundas, lo que supone un reforzamiento de la posición institucional de aquéllas, precisamente, cuando se habían alzado numerosas voces pidiendo la supresión de las Diputaciones Provinciales. Por ello, debemos analizar de manera separada el tratamiento que la LRSAL otorga a municipios y provincias pues, como se acaba de señalar, los resultados son completamente diferentes.

\section{2.a. Las competencias en materia de turismo de los municipios tras la LRSAL}

El esquema competencial de los municipios que se había instaurado con la Ley de Bases de 1985 consistía, primero, en un listado de materias sobre las que los municipios ejercerían competencias "en todo caso", pues se entendían de interés local, y siempre de acuerdo a la legislación estatal y autonómica. En segundo lugar, los municipios también podían ejercer competencias delegadas por otras Administraciones Públicas, así como otras complementarias de las propias de dichas Administraciones; en todo caso, tanto las delegadas como las complementarias, en modo alguno se consideraban competencias propias y su régimen jurídico era totalmente diferente al de aquéllas. Por último, pero no menos importante, también se articulaban una serie de servicios municipales de prestación obligatoria en función de la población del municipio, que se consideran esenciales (agua, alcantarillado, recogida de basuras,...) y, en muchos casos, con connotaciones turísticas ciertamente relevantes.

La irrupción de la LRSAL no va a suponer una variación radical, desde el punto de vista formal, de este esquema competencial, si bien desaparecen las llamadas competencias complementarias ${ }^{15}$ o "impropias", pues una de las finalidades de dicha ley es evitar las duplicidades competenciales entre los municipios y otras Administraciones Públicas, y se entendía que a través de esa vía los municipios estaban ejerciendo competencias que no les correspondían y para lo cual carecerían de los recursos económicos necesarios, ocasionando parte de la deuda pública que se debía reducir ${ }^{16}$.

${ }^{14}$ A este respecto, se puede ver, entre otros muchos, Almeida Cerreceda, M., op. cit., pg. 1 y ss.

${ }^{15}$ Reguladas en el artículo 28 de la antigua redacción de la Ley de Bases de Régimen Local de 1985.

16 Ver al respecto, Alonso Más, Mª J.: "El nuevo régimen de las competencias municipales". En Domingo Zaballos, M.J. (Coord.): Reforma del Régimen Local. La Ley de Racionalización y Sostenibilidad de la Administración Local: Veintitrés Estudios. Thomson Reuters-Aranzadi. Cizur 
Sin embargo, desde un punto de vista material, la reducción de competencias propias que sufren los municipios tras la LRSAL es, en nuestra opinión, innegable. Centrándonos exclusivamente en el ámbito del turismo, el artículo 25.2 , letra h), indica que "el municipio ejercerá en todo caso como competencias propias, en los términos de la legislación del Estado y de las Comunidades Autónomas, en la siguientes materias:... h) Información y promoción de la actividad turística de interés y ámbito local". Por el contrario, en la anterior redacción de ese mismo artículo, en la letra m), se aludía, como ya comentamos, al "turismo" sin más restricciones.

Una simple lectura de ambas redacciones permite derivar una mayor concreción en las facultades ahora reconocidas respecto a lo dicho en la anterior redacción, pues se limita a la información y promoción del turismo local, es decir, a poco más que la apertura de oficinales municipales de información turística, mientras que la anterior redacción dejaba mucho más margen a que la legislación autonómica atribuyera a los municipios, como competencias propias, otras que excedieran de la simple "información y promoción”, lo que, por otro lado, así ha ocurrido. La pregunta que nos debemos hacer es clara, ¿qué sucede con esas competencias locales en materia de turismo atribuidas actualmente por la legislación sectorial autonómica y que tienen un difícil acomodo en la nueva redacción del citado artículo 25 ?

Posiblemente la solución tiene que ser la misma que se ha planteado para otras materias que también han sufrido una sensible reducción o, incluso, su desaparición, tras la reforma realizada por la LRSAL, y así, como ha indicado Lozano Cutanda ${ }^{17}$, cabe que se produzca su transformación, bien en competencias delegadas por parte de la Comunidad Autónoma respectiva, como de hecho la propia Ley impulsa, en cuanto que entiende en su artículo 27, apartado 3, que "las Comunidades Autónomas podrán delegar, siguiendo criterios homogéneos, las siguientes competencias:... j) Promoción y gestión turísticas", donde se pueden incluir, aunque sea realizando una interpretación amplia, las facultades que las leyes autonómicas de regulación del turismo prevén como de titularidad local, bien utilizar la vía del artículo 7.4 de la LRBRL en su nueva redacción, que permite a los municipios desarrollar competencias diferentes de las propias o delegadas, aunque para ello deben probar que no se pone en riesgo la sostenibilidad financiera del conjunto de la Hacienda municipal ni se incurre en duplicidad con otra Administración Pública, para lo que son esenciales los informes previos vinculantes que emitan la Administración competente por razón de la materia (las Comunidades

Menor (Navarra). 2014. Pg. 157 y ss.

17 Ver Lozano Cutanda, B: “¿Qué será de las OMICs tras la Ley 27/2013, de racionalización y sostenibilidad de la Administración Local?”. Consultado el 23/09/2015 en www.uclm.es/Actividades/repositorio/pdf/doc_5214_7089.pdf 
Autónomas en este caso) y la Administración que tenga atribuida la tutela financiera sobre la sostenibilidad económica de las nuevas competencias, si bien, para nosotros, esta segunda vía se antoja más difícil que la conversión en competencias delegadas pues el espíritu de la LRSAL es que los municipios no ostenten más competencias que las propias o delegadas (art. 7.2 LRBRL), habiendo suprimido, como ya dijimos, las complementarias.

No obstante, estas posibles soluciones no son más que una salida teórica a un problema de falta de coordinación entre el contenido de la LRSAL y las leyes autonómicas que regulan el turismo, pero no debemos olvidar que, por un lado, las Comunidades Autónomas se han posicionado en contra y se decantan por mantener la situación que se venía desarrollando antes de la reforma ${ }^{18}$, y sobre todo, ello supone una reducción del ámbito competencial propio de los municipios, pues competencias que antes de la reforma poseían tal carácter, ahora pasarían a ser competencias delegadas o de otro tipo, pero en ningún caso propias, y sometidas por ello a un régimen mucho más estricto que éstas, como refleja, para las delegadas, el apartado 4 del citado artículo 27 de la LRSAL, al indicar que "la Administración delegante podrá, para dirigir y controlar el ejercicio de los servicios delegados, dictar instrucciones técnicas de carácter general y recabar, en cualquier momento, información sobre la gestión municipal, así como enviar comisionados y formular los requerimientos pertinentes para la subsanación de las deficiencias observadas. En caso de incumplimiento de las directrices, denegación de las informaciones solicitadas, o inobservancia de los requerimientos formulados, la Administración delegante podrá revocar la delegación o ejecutar por sí misma la competencia delegada en sustitución del Municipio", e incluso, "los actos del Municipio podrán ser recurridos ante los órganos competentes de la Administración delegante". En definitiva, también en materia de turismo, la reducción de las facultades propias de los municipios tras la aprobación de la LRSAL es indudable.

\section{2.b. Las competencias de las Diputación Provinciales tras la LRSAL}

Si los municipios han sufrido, en nuestra opinión, una reducción importante en su ámbito competencial propio tras la aprobación de la LRSAL, muy diferente es el papel que dicha reforma reserva a las Diputaciones Provinciales. Estas han visto acentuado su papel de apoyo a los municipios, hasta el punto de posibilitar que las mismas "coordinen" la prestación de determinados servicios esenciales, lo que equivale a una efectiva prestación de tales servicios por parte de aquellas (artículo 26.3 de la LRBRL, en su nueva redacción). Sin

${ }^{18}$ Ver Lozano Cutanda, B. Op. cit. 
entrar en otras consideraciones, lo cierto es que ello, unido a la desaparición de la dispensa municipal para la prestación de tales servicios, puede posibilitar una efectiva prestación de los mismos, lo que supone un beneficio para los vecinos de tales municipios, y en su caso, para los turistas, en cuanto que también requieren dichos servicios.

Pero, al margen de ello, no resulta difícil interpretar que las competencias atribuidas por las leyes autonómicas sobre turismo a las Diputaciones se pueden integrar en alguna de las competencias propias que enumera el artículo 36. 1 de la LRBRL en su nueva redacción, por ejemplo, "la cooperación en el fomento del desarrollo económico y social y en la planificación en el territorio provincial, de acuerdo con las competencias de las demás Administraciones Públicas en este ámbito" (letra d) o "la asistencia y cooperación jurídica, económica y técnica a los municipios, especialmente los de menor capacidad económica y de gestión" (letra b), además de poder ser transformadas en competencias delegadas de manera similar a la vía ya estudiada para los municipios. Ciertamente, en nuestra opinión, visto el nuevo papel que la LRSAL atribuye a las Diputaciones Provinciales, la posibilidad que éstas tienen ahora para intervenir en materia de turismo, bien de manera directa, bien de manera indirecta, puede aumentar considerablemente respecto a la situación de mera coordinación municipal y promoción de los intereses peculiares de la provincia que la antigua redacción de la Ley de Bases de Régimen Local les reservaba.

\section{Conclusiones}

El régimen local español ha sufrido la modificación más intensa desde la aprobación en 1985 de la Ley de Bases de Régimen Local. Sin embargo, las consecuencias para municipios y provincias han sido ciertamente diversas: mientras que, en nuestra opinión, el ámbito competencial propio de los primeros se ha reducido considerablemente, las Diputaciones Provinciales han visto aumentado su nivel competencial, lo que puede derivar en que desempeñen un papel ciertamente relevante que no habían poseído en nuestra historia reciente.

Esta situación también se aprecia en materia de turismo. Los municipios han visto reducidas sus competencias propias en dicha materia, mientras que las Diputaciones Provinciales pueden aumentar de manera notable su capacidad de intervención sobre la misma.

Sin embargo, se ha puesto de manifiesto una falta de coordinación entre la legislación autonómica de regulación del sector y la dicción que al respecto se recoge en la legislación básica estatal, pues las normas autonómicas atribu- 
yen a los municipios facultades que van más allá de la estricta información y promoción que les reconoce la LRSAL. La transformación de las mismas en competencias delegadas puede ser la vía que permita una relación lógica entre el contenido de dicha legislación básica y el de las normas autonómicas, pero ello supone una disminución en la calidad de las competencias municipales sobre turismo, al pasar de propias a delegadas, con la variación en el régimen jurídico de las mismas que ello conlleva. 


\section{REFERENCIAS}

Almeida Cerreceda, M., "La reforma de la planta, organización, articulación y estructura competencia de la Administración Local”, ponencia presentada en el VIII Congreso de la Asociación Española de Profesores de Derecho Administrativo, celebrado en Alicante los días 8 y 9 de febrero de 2013, disponible en la pg. web de la AEPDA.

Alonso MÁs, Ma. J.: "El nuevo régimen de las competencias municipales”. En Domingo Zaballos, M.J. (Coord.): Reforma del Régimen Local. La Ley de Racionalización y Sostenibilidad de la Administración Local: Veintitrés Estudios. Thomson Reuters-Aranzadi. Cizur Menor (Navarra). 2014.

Bermejo Vera, J.: “Administración Pública y turismo”. REVL. No 223. Julio-septiembre. 1984.

Boix Palop, A., "Tres notas explicativas sobre el sentido y orientación de la Ley 27/2013, de racionalización y sostenibilidad de la Administración local: limitación de la autonomía local, recentralización y redefinición de los mercados de servicios locales". Diario del Derecho municipal., Iustel. Tres de enero de 2014.

CAls, J: Turismo y política turística española. Ed. Ariel. Barcelona. 1984.

Castillo Blanco, F., "Una lectura de urgencia de la Ley 27/2013, de 27 de diciembre, de racionalización y sostenibilidad de la Administración local". Diario del Derecho municipal. Iustel. Tres de enero de 2014.

Domingo Zaballos, M.J. (Coord.): Reforma del Régimen Local. La Ley de Racionalización y Sostenibilidad de la Administración Local: Veintitrés Estudios. Ed. Thomson Reuters-Aranzadi. Cizur Menor (Navarra). 2014

Fernández Álvarez, J.: Curso de Derecho Administrativo Turístico. Ed. Nacional. Madrid. Tomo I.1974.

FernÁndez Fuster, L.: Historia general del turismo de masas. Madrid, 1991.

García de EnTERría, E.: Estudios sobre autonomías territoriales. Ed. Cívitas. Madrid. 1985.

Lozano Cutanda, B: “¿Qué será de las OMICs tras la Ley 27/2013, de racionalización y sostenibilidad de la Administración Local?”. Consultado el 23/09/2015 en www.uclm.es/Actividades/repositorio/pdf/doc_5214_7089.pdf 
Martín Mateo, R., Martín-Retortillo, L., y Villar Palasí, J.L: “Aspectos jurídico administrativos del turismo". Ponencia presentada en el Primer Congreso Italo-Español de Profesores de Derecho Administrativo posteriormente incluida en un volumen publicado por el Ministerio de Información y Turismo. Madrid. 1970.

Mellado Ruiz, L.: "Notas críticas sobre el Anteproyecto de ley para la racionalización y sostenibilidad de la Administración local, entre la reforma y la intervención". Revista CEMCI. N 17. 2012.

Mir BAgó, J: Comentarios sobre el Estatuto de Autonomía de Cataluña. Institu d'Estudis Autonòmics. Barcelona. 1990.

Nogueira López, A., "Crisis económica y cambios estructurales en el régimen del ejercicio de actividades". En El Derecho Público de la crisis económica. Transparencia y sector público. Hacia un nuevo Derecho Administrativo. Actas del VI Congreso de la AEPDA. INAP. Madrid. 2012.

Ortega Álvarez, L: El régimen constitucional de las competencias locales. INAP. Madrid. 1988.

Parejo Alfonso, L., Jiménez-Blanco, A., y Ortega Álvarez, L: Manual de Derecho Administrativo (3 ${ }^{a}$ edición). Ed. Ariel, Barcelona, 1994.

Roca Roca, E., Ceballos Martín, Mª M., y Pérez Guerra, R.: La regulación jurídica del turismo en España. Servicio de Publicaciones de la Universidad de Almería. Almería. 1988.

Roca Roca, E., y Pérez Martos, J.: “Administación municipal y turismo”. XI Congreso Italo-Español de Profesores de Derecho Administrativo. Cedecs Editorial. Barcelona. 1998.

Villanueva Cuevas, A..: El turismo como ámbito de intervención administrativa: desde la parcialidad a la globalidad. Ed. Alfonsípolis, Cuenca, 2012. 


\section{"La factura electrónica en la contratación pública"}

Alfredo Ramos*

Resumen: Se analiza en las siguientes páginas la normativa que regula una forma específica de facturación que se pretende imponer en la contratación pública: la factura electrónica. Y ello en virtud de lo previsto en la Disposición Adicional decimosexta del TRLCSP, en cuyo apartado $1^{\circ}$ letra f) se dispone que las facturas electrónicas que se emitan en los procedimientos de contratación se regirán por lo dispuesto en la normativa especial que resulte de aplicación.

Palabras clave: Contratación pública; factura electrónica; pago del precio; morosidad.

Abstract: In the following pages, we analyze the normative which regulates a specific form of billing that it is intended to be imposed on public recruitment: the electronic invoice. And that as expected in the Additional Sixteenth Regulation of TRLCSP in which first point-f letter it is disposed that the electronic invoices issued in the recruitment proceedings will be in effect by the order in the special normative as a result of the application.

Key words: Public procurement; electronic invoice; price paid; payment delays.

* Doctor en Derecho. Abogado. Profesor asociado de la Universidad de Castilla La Mancha 


\section{Marco jurídico de la factura}

La factura es un documento que refleja la entrega de un producto o la provisión de un servicio, junto a la fecha de devengo, además de indicar la cantidad a pagar como contraprestación ${ }^{1}$. En la factura se encuentran los datos del expedidor y del destinatario ${ }^{2}$, el detalle de los productos y servicios suministrados, los precios unitarios, los precios totales, los descuentos y los impuestos ${ }^{3}$.

En materia de facturación la normativa comunitaria ${ }^{4}$ que reguló la materia se produjo con la aprobación de la Directiva 2001/115/CE del Consejo, de 20 de diciembre de 2001, que modificó la Directiva 77/388/CEE del Consejo, de 17 de mayo de 1977, en materia de armonización de las legislaciones de los Estados miembros relativas a los impuestos sobre el volumen de negocios-Sistema común del Impuesto sobre el Valor Añadido: Base imponible uniforme sexta Directiva. Estas modificaciones tenían por objeto la armonización y simplificación de la expedición de facturas en el ámbito del Impuesto sobre el Valor Añadido.

Por su parte, la Directiva 2006/112/CE del Consejo de 28 de noviembre de 2006, relativa al sistema común del impuesto sobre el valor añadido, sustituyó, desde el 1 de enero de 2007, a la Directiva 77/388/CEE del Consejo de 17 de mayo de 1977.

Sin embargo, la existencia de todavía un amplio número de opciones ofrecidas a los Estados miembros de la Unión Europea ha dado lugar a que las normativas internas mantenidas por los mismos, en materia de facturación, no hayan alcanzado el grado de armonización o aproximación deseado.

Esta divergencia entre legislaciones de los distintos Estados miembros y la existencia de ciertas lagunas no reguladas por la Directiva comunitaria, condujeron a la aprobación de la Directiva 2010/45/UE de 13 de julio de 2010, por la que se modifica la Directiva 2006/112/CE relativa al sistema común del impuesto sobre el valor añadido, en lo que respecta a las normas de

\footnotetext{
1 Garrigues Y Díaz-Cañabate, J., Curso de Derecho mercantil, vol. 4, Bogotá, 1988, pág. 27 , define la factura como "la lista de mercancías objeto de un contrato con la mención de sus características (naturaleza, calidad y tipo), su precio y su cantidad".

2 Urea González, R., "Contribución al estudio de la factura de compraventa mercantil", en AA. VV., Estudios de Derecho mercantil en homenaje al profesor Antonio Polo, Madrid, 1981, págs. 1.153-1.179. Más amplio es el concepto que encontramos en Sánchez Calero, F., Sánchez-Calero Guilarte, J., Instituciones de Derecho mercantil, vol. 2, 29 edición, Cizur Menor, 2006, pág. 183. 3 Inza, J., La factura electrónica, Ed. Red.es Ministerio de Industria, Turismo y Comercio, Madrid, 2010, pág. 5.

${ }^{4}$ La introducción en nuestro Ordenamiento de la factura electrónica se produjo en virtud del art. 88.2 de la Ley 37/1992, de 28 de diciembre, del Impuesto sobre el Valor Añadido (BOE núm. 312, de 29-12-1992), que, en su versión original, establecía que "la repercusión del impuesto deberá efectuarse mediante factura o documento análogo, que podrán emitirse por vía telemática, en las condiciones y con los requisitos que se determinen reglamentariamente.
} 
facturación ${ }^{5}$, que debía transponerse al ordenamiento jurídico interno de los Estados miembros antes del 1 de enero de 2013. En respuesta a esa exigencia comunitaria, en nuestro país se promulgó el Real Decreto 1619/2012, de 30 de noviembre, por el que se aprueba el Reglamento por el que se regulan las obligaciones de facturación ${ }^{6}$.

Siguiendo su Exposición de Motivos, las principales novedades que se introducen en el nuevo reglamento de facturación, con fecha de entrada en vigor 1 de enero de 2013, son las siguientes:

1. Como novedad relativa a la obligación de expedir factura, se establece que no se exigirá tal obligación en el caso de determinadas prestaciones de servicios financieros y de seguros, salvo cuando dichas operaciones se entiendan realizadas en el territorio de aplicación del Impuesto, o en otro Estado miembro de la Unión Europea, y estén sujetas y no exentas.

2. Con la finalidad de establecer un sistema armonizado de facturación, en el sentido marcado por la Directiva 2010/45/UE antes mencionada, y de promover y facilitar el funcionamiento de los pequeños y medianos empresarios, así como de los profesionales, se establece un sistema de facturación basado en dos tipos de facturas: la factura completa u ordinaria y la factura simplificada, que viene a sustituir a los denominados tiques.

3. Asimismo, la nueva regulación en materia de facturación supone un decidido impulso a la facturación electrónica, cumpliendo la finalidad marcada por la Directiva comunitaria, bajo el principio de un mismo trato para la factura en papel y la factura electrónica, como instrumento para reducir costes y hacer más competitivas a las empresas.

4. Se establece una nueva definición de factura electrónica, como aquella factura que, cumpliendo los requisitos establecidos en el propio Reglamento, haya sido expedida y recibida en formato electrónico. 5. Por otra parte y, como recuerda la Directiva 2010/45/UE mencionada, se establece que las facturas en papel o electrónicas deben reflejar la realidad de las operaciones que documentan y corresponderá a los sujetos pasivos garantizar esta certidumbre durante toda su vigencia, sin que esta exigencia pueda suponer la imposición de nuevas cargas administrativas a los empresarios o profesionales. De esta forma, el

\footnotetext{
${ }^{5}$ Que ha de ponerse en relación con la Decisión de la Comisión de 2 de noviembre de 2010, por la que se establece el Foro Europeo Multilateral sobre Facturación Electrónica (2010/C 326/07), que tendrá como cometido asistir a la Comisión en el seguimiento de la evolución del mercado de facturación electrónica y del grado de adopción de la misma en el sector industrial y de servicios de todos los Estados miembros.

${ }^{6} \mathrm{BOE} \mathrm{n}^{\mathrm{o}} 289$ de 1 de diciembre 2012
} 
sujeto pasivo podrá garantizar la autenticidad, integridad y legibilidad de las facturas que expida o conserve mediante los controles de gestión usuales de su actividad empresarial o profesional.

6. Esta igualdad de trato entre la factura en papel y la electrónica amplía, por tanto, las posibilidades para que el sujeto pasivo pueda expedir facturas por vía electrónica sin necesidad de que la misma quede sujeta al empleo de una tecnología determinada.

Así pues, podemos definir la factura como el justificante fiscal de la entrega de un producto o de la provisión de un servicio, que afecta al obligado tributario emisor (el vendedor) y al obligado tributario receptor (el comprador). El original debe ser custodiado por el receptor de la factura. Habitualmente, el emisor de la factura conserva una copia o la matriz (base de datos) en la que se registra su emisión, en cuyo caso no tiene por qué custodiar las copias de las facturas.

Las facturas pueden ser$^{7}$ :

- Ordinarias: Documentan la operación de prestación de servicios, venta o suministro.

- Rectificativas: Documentan correcciones de una o más facturas anteriores, o bien devoluciones de productos, envases y embalajes o comisiones por volumen.

- Recapitulativas: Documentan agrupaciones de facturas de un período.

Además existen las siguientes variantes:

- Pro-forma: Documenta una oferta, con indicación de la forma exacta que tendrá la factura tras el suministro. No tienen valor contable ni como justificante.

- Copia: Documenta la operación para el emisor, con los mismos datos que el original. Debe llevar la indicación de copia para permitir distinguirla del original.

- Duplicado: Documenta la operación para el receptor, en caso de pérdida del original. La expide el mismo emisor que expidió el original y tiene los mismos datos que el original. Debe llevar la indicación de duplicado para permitir distinguirla del original, especialmente para el caso de que reaparezca el original.

Es interesante mencionar que las tradicionales Notas de Abono no se contemplan en la normativa, aunque su función se cubre con las facturas rectificativas.

\section{Factura electrónica}

Se entenderá por factura electrónica ${ }^{8}$ aquella factura que, ajustándose a lo establecido en el Real Decreto 1619/2012, de 30 de noviembre, haya sido expe-

\footnotetext{
${ }^{7}$ Inza, J., La factura electrónica, Ed. Red.es Ministerio de Industria, Turismo y Comercio, Madrid, 2010, pág. 5.

${ }^{8}$ Una excelente aproximación al concepto y naturaleza jurídica de la factura electrónica lo podemos encontrar en Cruz Rivero, D., "La factura electrónica", $R C E$, nº 82, 2007, págs. 55 y ss.
} 
dida y recibida en formato electrónico. La expedición de la factura electrónica estará condicionada a que su destinatario haya dado su consentimiento.

Siguiendo en este punto la acertadísima descripción de Carrión Morillo9, podemos afirmar que la factura electrónica, con carácter general, al igual que la factura en papel, contendrá los siguientes datos:

- Número y, en su caso, serie. Dato que es fundamental para la contabilización de la factura, logrando una más rápida localización de la misma entre la documentación que guarda la empresa, en caso de que sea necesario.

- Fecha de expedición. Si se hubiese recibido pago anticipado, o la fecha de realización de las operaciones fuese distinta a la fecha de expedición de la factura, también habría que consignar aquélla. Las facturas deben ser expedidas en el momento de realizarse la operación, pero si el destinatario de la operación es un empresario que actúa como tal, deberán ser emitidas en el plazo de un mes contado a partir del momento citado. Un caso especial es el de la factura recapitulativa, en la cual se incluyen operaciones realizadas para un mismo destinatario en distintas fechas, siempre que se hayan realizado en un mismo mes natural.

- Nombre y apellidos, o razón social, según sea persona física o jurídica, del obligado a emitir factura y del destinatario de la misma.

- Número de Identificación Fiscal (NIF). Es un elemento importantísimo. De hecho, es necesario utilizar el NIF en todas aquellas «operaciones de trascendencia tributaria», según contemplaba el Real Decreto 338/1990, de 9 de marzo, por el que se regulaba la composición y la forma de utilización del Número de Identificación Fiscal. Por tanto, la comunicación obligatoria del NIF trasciende la factura para abarcar muchas otras relaciones de contenido tributario.

- Domicilio del expedidor de la factura y del destinatario de la misma. Esto se refiere al domicilio fiscal, que es el lugar de localización del obligado tributario (sea emisor o destinatario) en sus relaciones con la Administración tributaria. No debe confundirse el domicilio fiscal con el domicilio social de las personas jurídicas, pese a que ambos coincidan si en ese domicilio estuviese centralizada su gestión administrativa y la dirección de sus negocios. En otro caso, se atendería al lugar en donde se llevase a cabo dicha gestión o dirección para determinar el domicilio fiscal. En

${ }^{9}$ Carrión Morillo, D., "De la factura en papel a la factura electrónica: características fundamentales de la facturación en España”, Diario La Ley, Nº 6889, Sección Tribuna, 22 Feb. 2008. 
defecto de los criterios anteriores, el domicilio coincidirá con el lugar donde radique el mayor valor del inmovilizado de la persona jurídica.

- Descripción de las operaciones, ya sean ventas de bienes o prestaciones de servicios.

- Tipo/s impositivo/s aplicado/s a las operaciones.

- Cuota tributaria que se repercuta, en su caso, que deberá consignarse separadamente de la base imponible.

La autenticidad del origen de la factura electrónica, garantizará la identidad del obligado a su expedición y del emisor de la factura. Y la integridad del contenido de la factura electrónica, garantizará que el mismo no ha sido modificado. Para poder garantizar dicha autenticidad e integridad será válido cualquier medio de prueba admitido en Derecho, y, en particular:

a) Mediante una firma electrónica avanzada de acuerdo con lo dispuesto en el artículo 2.2 de la Directiva 1999/93/CE del Parlamento Europeo y del Consejo, de 13 de diciembre de 1999, por la que se establece un marco comunitario para la firma electrónica, basada, bien en un certificado reconocido y creada mediante un dispositivo seguro de creación de firmas, de acuerdo con lo dispuesto en los apartados 6 y 10 del artículo 2 de la mencionada Directiva, o bien, en un certificado reconocido, de acuerdo con lo dispuesto en el apartado 10 del artículo 2 de la mencionada Directiva.

Una firma electrónica avanzada es aquella que permite identificar al firmante y detectar cualquier cambio ulterior de los datos firmados, que está vinculada al firmante de manera única y a los datos a que se refiere y que ha sido creada por medios que el firmante puede mantener bajo su exclusivo control. Esa firma estará basada en un certificado reconocido, entendiendo por tal el que pueda acreditar la identidad y demás circunstancias de los solicitantes.

b) Mediante un intercambio electrónico de datos (EDI), tal como se define en el artículo 2 del anexo I de la Recomendación 94/820/CE de la Comisión, de 19 de octubre de 1994, relativa a los aspectos jurídicos del intercambio electrónico de datos, cuando el acuerdo relativo a este intercambio prevea la utilización de procedimientos que garanticen la autenticidad del origen y la integridad de los datos.

c) Mediante otros medios que los interesados hayan comunicado a la Agencia Estatal de Administración Tributaria con carácter previo a su utilización y hayan sido validados por la misma.

De esta definición extendida en todo el mercado, se transmiten tres condicionantes para la realización de e-Factura ${ }^{10}$ :

${ }_{10}$ Se ocupó de la regulación del proceso de digitalización para que se garantizase una imagen fiel e íntegra de cada documento firmado con firma electrónica la Resolución de 24 de octubre de 
- $\quad 1^{\circ}$ Se necesita un formato electrónico de factura de mayor o menor complejidad (EDIFACT, XML, PDF, html, doc, xls, gif, jpeg o txt, entre otros).

- $\quad 2^{\circ}$ Es necesario una transmisión telemática (tiene que partir de un ordenador, y ser recogida por otro ordenador).

- $\quad 3^{\circ}$ Este formato electrónico y transmisión telemática, deben garantizar su integridad y autenticidad a través de una firma electrónica reconocida.

En palabras de Punzón Moraleda ${ }^{11}$, se puede decir que las ventajas que ofrece la factura electrónica respecto a la factura tradicional suponen un considerable ahorro en papel lo cual conlleva que se mejore en la gestión del trabajo por medio de procesos más ágiles, eficaces y menos costosos en mano de obra. Con lo cual, al ahorro energético en la naturaleza se debe sumar el ahorro en gestión empresarial que se consigue. Y, en cuanto al ámbito industrial, o mejor dicho, empresarial, la factura electrónica favorece el desarrollo tecnológico de la utilización de las tecnologías de la información y las comunicaciones por parte del tejido empresarial español tanto en su gestión interna (mejor precisión en la contabilidad de los apuntes contables), como en sus procesos de negocio, incidiendo de manera notable en la productividad y competitividad en el mercado global. Igualmente se favorece la interrelación entre las empresas y la Administración Pública de una forma más dinámica y transparente sobre todo a la hora de la contratación pública.

De igual manera Inza ${ }^{12}$ glosa las excelencias de la facturación electrónica, destacando entre sus ventajas:

- Ahorro de costes: tanto del lado del emisor como del receptor. Derivado de la supresión del papel, el abaratamiento de los medios de comunicación electrónicos (en contraposición a los medios tradicionales de envío postal), eliminación de los gastos de franqueo, gastos derivados de la introducción manual de datos.

- Mejora de la eficiencia: la liberación de tareas administrativas permite destinar los recursos humanos a aspectos productivos en las compañías.

- Integración con ERPs: desde el punto de vista del emisor continúa

2007, de la Agencia Estatal de Administración Tributaria, sobre procedimiento para la homologación de software de digitalización contemplado en la Orden EHA/962/2007, de 10 de abril de 2007, publicada en el BOE n ${ }^{0} 262$ de 1 de noviembre de 2007.

11 Punzón Moraleda, J. y Sánchez Rodríguez, F., La utilización de medios electrónicos, informáticos y telemáticos en la Ley 30/2007, de Contratos del Sector Público, La Ley, Madrid, 2009, pág. 192.

12 Inza, J., La factura electrónica, Ed. Red.es Ministerio de Industria, Turismo y Comercio, Madrid, 2010, pág. 9. 
el proceso que ya se está realizando electrónicamente. Un simple clic desde el ERP y la factura es emitida y enviada. Desde el lado del receptor los datos se pueden introducir automáticamente en sus aplicaciones.

- Optimización de la tesorería: la automatización permite cuadrar los apuntes contables y comparar documentos (albarán/factura), minimizando a la vez el margen de error humano.

- Obtención de información en tiempo real: permite verificar el estado en el que se encuentra una factura y toda su información asociada (errores, rectificaciones, cobros, pagos, recepción de mercancías, albaranes,...) de forma exacta y actual.

- Reducción de tiempos de gestión: la inmediatez del envío y recepción de facturas por medios telemáticos convierte este trámite en un elemento que deja de tener sentido. Además, permite solucionar las discrepancias en muy poco tiempo.

- $\quad$ Agilidad en la toma de decisiones: la inmediatez de las comunicaciones permite adoptar decisiones, como la necesidad de financiación, en un espacio más corto de tiempo.

- Administración y contabilidad automatizadas: la integración en los sistemas de la empresa permite que toda la inserción de datos y las operaciones contables requieran mucha menos participación humana. Control de acciones erróneas: a través de sistemas de alertas que detectan discrepancias entre operaciones de contabilidad y facturación en la aplicación de tipos erróneos.

- Uso eficaz de recursos financieros: la adopción de la factura electrónica favorece el acceso a medios de financiación como el factoring o el confirming.

- Mejor aprovechamiento de la habilidad de los empleados, que pueden dedicar su tiempo a tareas de mayor valor añadido para la empresa.

- Reducción de controversias en la gestión de facturas entre emisor y receptor.

- Mejoras en la resolución de incidencias, que disminuyen y se resuelven de forma más rápida.

- Reducción de plazos de cobro, ya que la conformidad de las facturas se consigue con más celeridad.

- Mejoras en la negociación de los plazos de pago, ya que la certeza en la aplicación de los plazos que no se ven afectados por demoras por incidencias, permite un cierto margen de maniobra adicional.

- Mejora de la relación comercial y de la imagen de la empresa, 
como consecuencia de los efectos anteriores.

- Cumplimiento de obligaciones cuando la facturación electrónica sea exigida en los procesos de licitación.

Se consigue, en definitiva, una mayor calidad de servicio que repercute a su vez en una mayor competitividad de la empresa.

\section{La factura electrónica en el TRLCSP.}

Como desglosa Martínez Fernández ${ }^{13}$, en la Administración analógica, realizada la prestación contractual por el correspondiente proveedor, éste emitirá una factura cumpliendo los requisitos previstos en el Reglamento de Facturación y lo registrará en el registro de la administración o del órgano en el que ha prestado el servicio. El registro remitirá la factura al servicio correspondiente que registrará provisionalmente la factura en el sistema de información contable correspondiente y remitirá al servicio gestor ésta para que preste su conformidad (en la práctica el servicio gestor estampa un sello con la leyenda Conforme y la fecha y el cargo de quien presta su conformidad firmando en la factura). Prestada la conformidad (aunque tampoco es infrecuente la devolución de facturas por errores en su confección o porque no se está conforme con ella) se acompañará a la factura, el correspondiente documento contable de reconocimiento de obligación y propuesta de pago y se enviará por el trámite tradicional (en papel y por nota interior). El servicio correspondiente realizará la grabación preliminar del documento contable en el sistema de información siendo generalmente (en el ámbito de las Administraciones públicas cuando la correspondiente ejecución presupuestaria está sometida a función interventora) sometida a intervención formal del pago y en su caso contabilizada en el sistema por la correspondiente Intervención.

En cambio, disponiendo de una plataforma de factura electrónica, el esquema del proceso de reconocimiento de obligaciones derivadas de la ejecución contractual y su posterior pago en las Administraciones públicas, se acomoda al siguiente modelo:

Realizada la prestación contractual por el correspondiente proveedor, este confeccionará la factura electrónica, si dispone de un sistema propio de facturación electrónica, la firmará y enviará a la correspondiente plataforma de factura electrónica; si el proveedor careciera de ese sistema de facturación electrónica propio, siempre que esté registrado en el sistema, podrá confeccionar en la propia plataforma su factura siendo firmada electrónicamente por la Plataforma. La Plataforma lo enviará automáticamente al Registro electrónico de la Administración Pública correspondiente, el cual está disponible las veinticuatro horas de todos los días del año. El registro electrónico emitirá automáticamente por el mismo medio un recibo firmado electrónicamente,

${ }^{13}$ Martínez Fernández, J., " Cuestiones funcionales a considerar en la construcción de un sistema de contratación electrónica”, Revista General de Derecho Administrativo, n² 27, 2011, pág. 17. 
con la copia del escrito, comunicación o solicitud presentada, con expresión de la fecha y hora de presentación y el número de entrada de registro y en su caso, la enumeración y denominación de los documentos adjuntos seguida de la huella electrónica de cada uno de ellos. Simultáneamente el Registro remitirá la factura al órgano competente. A partir de aquí se puede, como dispone el Decreto 87/2010 de la Generalitat Valenciana, regular que la factura original es la factura remitida electrónicamente pero que podrán emitirse copias auténticas válidas con código seguro de verificación que tendrán la eficacia legal prevista en el artículo 46 de la LRJPAC, conservándose la factura original en poder de la administración para comprobar la veracidad de las copias. Una vez se ha obtenido esta copia impresa con código seguro de verificación ya se tramita en el circuito económico-administrativo como hemos descrito más arriba.

La D.A. $16^{\mathrm{a}}$ del TRLCSP, en su apartado f), según redacción dada por el número siete de la disposición final tercera de la Ley 25/2013, de 27 de diciembre, de impulso de la factura electrónica y creación del registro contable de facturas en el Sector Público («B.O.E.» no 311 de 28 de diciembre), establece que todos los actos y manifestaciones de voluntad de los órganos administrativos o de las empresas licitadoras o contratistas que tengan efectos jurídicos y se emitan a lo largo del procedimiento de contratación deben ser autenticados mediante una firma electrónica reconocida, y las facturas electrónicas que se emitan en esos procedimientos de contratación se regirán en este punto por lo dispuesto en la Ley 25/2013, de 27 de diciembre, de impulso de la factura electrónica y creación del registro contable de facturas en el Sector Público.

Procede, por tanto, el estudio de esta reciente norma para entender la regulación de la factura electrónica en lo tocante a la contratación con el Sector Público. Y en este sentido lo primero que se ha de poner de manifiesto es el vuelco radical que esta normativa introduce en el tradicional sistema que venía padeciendo el contratista con el Sector Público, que veía demorada la satisfacción de su crédito con prácticas que se apartaban del recto camino marcado por nuestra legislación. Así, los contratistas se plegaban a los deseos de las Administraciones, rehaciendo, refundiendo, modificando o postergando facturas para acomodarlas a la disponibilidad presupuestaria y de tesorería de la Administración contratante; y por su parte, tampoco era práctica inhabitual que las Administraciones abandonasen en los cajones facturas por servicios prestados o entregas realizadas por los proveedores, sin reconocer las obligaciones de pago, sirviéndose de esta argucia o martingala para equilibrar artificiosamente las cuentas públicas.

Ya el Preámbulo de la nueva norma se esgrime como propósito acabar con esta situación, y ello con la intención de mejorar la competitividad de las empresas por la vía de reducir la morosidad de las Administraciones Públicas. Para conseguir el fin propuesto y en el marco del informe de la Comisión para 
la reforma de las Administraciones Públicas que contenía varias propuestas de reformas estructurales para erradicar la morosidad de las Administraciones Públicas, se publica esta Ley como exponente de una de estas reformas estructurales para agilizar los procedimientos de pago al proveedor y dar certeza de las facturas pendientes de pago existentes. Entiende el legislador que este control informatizado y sistematizado de las facturas favorecerá un seguimiento riguroso de la morosidad a través de un indicador, el periodo medio de pagos, que visualizará el volumen de deuda comercial de las Administraciones y permitirá, llegado el caso, aplicar los nuevos mecanismos previstos en la Ley Orgánica 2/2012 de 27 de abril, de Estabilidad Presupuestaria y Sostenibilidad Financiera, en la que el control de la deuda comercial forma parte del principio de sostenibilidad financiera.

Entremos en el análisis de la norma, que consta de un total de 13 artículos, agrupados en cinco capítulos, seis disposiciones adicionales, tres disposiciones transitorias, una disposición derogatoria única y ocho disposiciones finales.

El Capítulo I concreta que el objeto de la Ley es impulsar el uso de la factura electrónica, crear el registro contable de facturas, regular el procedimiento para su tramitación en las Administraciones Públicas y las actuaciones de seguimiento por los órganos competentes. Y en cuanto a su ámbito de aplicación subjetivo la norma especifica que se aplica a las facturas emitidas por la entrega de bienes o la prestación de servicios a las Administraciones Públicas, entendiendo por tales los entes, organismos y entidades a que se refiere el artículo 3.2 del TRLCSP. En este sentido podemos afirmar que nos encontramos ante una norma básica, y como tal se impone a todas las Administraciones Públicas.

El Capítulo II establece la obligación para el proveedor que haya expedido la factura por los servicios prestados o bienes entregados a cualquier Administración Pública de presentarla ante un registro administrativo, en los términos previstos en el artículo 38 de la Ley 30/1992 de 26 de noviembre, de Régimen Jurídico de las Administraciones Públicas y del Procedimiento Administrativo Común, en el plazo de treinta días desde la fecha de entrega efectiva de las mercancías o la prestación de servicios. En tanto no se cumplan estos requisitos de tiempo y forma de presentación no se entenderá cumplida esta obligación de presentación de facturas en el registro.

El Capítulo III se refiere al uso de la factura electrónica en el sector público, estableciendo que todos los proveedores que hayan entregado bienes o prestado servicios a la Administración Pública podrán expedir y remitir factura electrónica, pero que en todo caso ${ }^{14}$ estarán obligadas al uso de la factura

${ }^{14}$ No obstante, las Administraciones Públicas podrán excluir reglamentariamente de esta obligación de facturación electrónica a las facturas cuyo importe sea de hasta 5.000 euros y a las 
electrónica y a su presentación a través del punto general de entrada que corresponda las entidades siguientes:

a) Sociedades anónimas;

b) Sociedades de responsabilidad limitada;

c) Personas jurídicas y entidades sin personalidad jurídica que carezcan de nacionalidad española;

d) Establecimientos permanentes y sucursales de entidades no residentes en territorio español en los términos que establece la normativa tributaria;

e) Uniones temporales de empresas;

f) Agrupación de interés económico, Agrupación de interés económico europea, Fondo de Pensiones, Fondo de capital riesgo, Fondo de inversiones, Fondo de utilización de activos, Fondo de regularización del mercado hipotecario, Fondo de titulización hipotecaria o Fondo de garantía de inversiones.

A la vista de lo cual podemos afirmar que la norma pretende evitar la "brecha tecnológica" de muchas Administraciones al incluir entre sus estipulaciones previsiones para suavizar el rigor automático de la Ley y dar tiempo a la adaptación tecnológica. En particular me refiero a que el uso de la factura electrónica es obligatorio ante todas las Administraciones Públicas para facturas de importe superior a 5.000 euros desde el 15 de Enero de 2005.

También se ocupa este tercer capítulo del formato que deban tener las facturas electrónicas, disponiendo que deberán tener un formato estructurado $^{15}$ y estar firmadas con firma electrónica avanzada basada en un certificado reconocido, de acuerdo con lo dispuesto en el artículo 10.1 a) del Real Decreto 1619/2012 de 30 de noviembre, por el que se aprueba el Reglamento por el que se regulan las obligaciones de facturación. También se admitirá el sello electrónico avanzado basado en un certificado reconocido que deberá identificar a la persona jurídica o entidad sin personalidad jurídica que selle la factura electrónica, a través de su denominación o razón social y su número de identificación fiscal.

Por último este capítulo tercero crea el denominado punto general de entrada de facturas electrónicas, del que dispondrán cada una de las Administraciones, con posibilidad de celebrar convenios o adherirse al punto ya implementado por la Administración General del Estado para compartir su uso y

emitidas por los proveedores a los servicios en el exterior de las Administraciones Públicas hasta que dichas facturas puedan satisfacer los requerimientos para su presentación a través del Punto general de entrada de facturas electrónicas, de acuerdo con la valoración del Ministerio de Hacienda y Administraciones Públicas, y los servicios en el exterior dispongan de los medios y sistemas apropiados para su recepción en dichos servicios.

15 Nos remitimos en este punto a la Orden HAP/1074/2014 de 24 de junio (BOE n ${ }^{\circ} 154$ de 25 de junio de 2014). 
que no sea necesario que cada Administración invierta recursos en desarrollar su propio Punto general de entrada de facturas electrónicas. A estos efectos se regulan las características mínimas que deben reunir estos puntos, disponiendo que permitirán el envío de facturas electrónicas, pudiendo el proveedor consultar el estado de la tramitación de las mismas. Todas las facturas electrónicas presentadas a través del punto general de entrada de facturas electrónicas producirán una entrada automática en un registro electrónico de la Administración Pública gestora de dicho punto general de entrada de facturas electrónicas, proporcionando un acuse de recibo electrónico con acreditación de la fecha y hora de presentación.

El Capítulo IV regula la creación del registro contable de facturas cuya gestión corresponderá al órgano o unidad administrativa que tenga atribuida la función de contabilidad y que estará interrelacionado o integrado con el sistema de información contable.

Lo más importante de este capítulo es el establecimiento del nuevo procedimiento para la tramitación de facturas, y que dispone que el registro administrativo en el que se reciba la factura la remitirá inmediatamente a la oficina contable competente para la anotación en el registro contable de la factura. Las facturas electrónicas presentadas en el correspondiente punto general de entrada de facturas electrónicas, serán puestas a disposición o remitidas electrónicamente, mediante un servicio automático proporcionado por dicho punto, al registro contable de facturas que corresponda en función de la oficina contable que figura en la factura. En la factura deberá identificarse los órganos administrativos a los que vaya dirigida de conformidad con la disposición adicional trigésima tercera del texto refundido de la Ley de Contratos del Sector Público, aprobado por el Real Decreto Legislativo 3/2011, de 14 de noviembre ${ }^{16}$.

La anotación de la factura en el registro contable de facturas dará lugar a la asignación del correspondiente código de identificación de dicha factura en el citado registro contable. En el caso de las facturas electrónicas dicho código será comunicado al Punto general de entrada de facturas electrónicas. El órgano o unidad administrativa que tenga atribuida la función de contabilidad la remitirá o pondrá a disposición del órgano competente para tramitar, si procede, el procedimiento de conformidad con la entrega del bien o la presta-

\footnotetext{
${ }^{16}$ No obstante, el Estado, las Comunidades Autónomas y los municipios de Madrid y Barcelona, podrán excluir reglamentariamente de esta obligación de anotación en el registro contable a las facturas cuyo importe sea de hasta 5.000 euros, así como las facturas emitidas por los proveedores a los servicios en el exterior de cualquier Administración Pública hasta que dichas facturas puedan satisfacer los requerimientos para su presentación a través del Punto general de entrada de facturas electrónicas, de acuerdo con la valoración del Ministerio de Hacienda y Administraciones Públicas, y los servicios en el exterior dispongan de los medios y sistemas apropiados para su recepción en dichos servicios.
} 
ción del servicio realizada por quien expidió la factura y proceder al resto de actuaciones relativas al expediente de reconocimiento de la obligación. Una vez reconocida la obligación por el órgano competente que corresponda, la tramitación contable de la propuesta u orden de pago identificará la factura o facturas que son objeto de la propuesta, mediante los correspondientes códigos de identificación asignados en el registro contable de facturas.

El Capítulo V recoge los efectos de la recepción de la factura, las facultades y obligaciones de los órganos de control interno y la colaboración con la Agencia Estatal de Administración Tributaria.

Las previsiones de la norma no serán aplicables a las facturas ya expedidas antes de su entrada en vigor, aunque podrán los proveedores presentarlas también ante un Registro administrativo. Y sobre este particular, ha de manifestarse que la Ley entró en vigor el 17 de enero de 2014, salvo lo relativo a las obligaciones de presentación de factura electrónica del artículo 4, que entró en vigor el 15 de enero de 2015, y la anotación en el registro contable de facturas, y la disposición final primera, por la que se modifica el apartado 4 del artículo 34 de la Ley 29/1987, de 18 de diciembre, del Impuesto sobre Sucesiones y Donaciones, que entraron en vigor el 1 de enero de 2014.

La aparición de esta normativa, además del ahorro de papel (cifrado por el Gobierno en 2,3 millones anuales y un beneficio neto anual de 51 millones de euros), vendrá a paliar (o a eliminar en el escenario más optimista) el riesgo de corruptelas y la morosidad endémica de las Administraciones. 


\section{REFERENCIAS}

CArrión Morillo, D., "De la factura en papel a la factura electrónica: características fundamentales de la facturación en España", Diario La Ley, N ${ }^{\circ}$ 6889, Sección Tribuna, 22 Feb. 2008.

Cruz Rivero, D., “La factura electrónica”, RCE, nº 82, 2007.

Garrigues y Díaz - Cañabate, J., Curso de Derecho mercantil, vol. 4, Bogotá, 1988-

InZA, J., La factura electrónica, Ed. Red.es Ministerio de Industria, Turismo y Comercio, Madrid, 2010.

Martínez Fernández, J., "Cuestiones funcionales a considerar en la construcción de un sistema de contratación electrónica", Revista General de Derecho Administrativo, $\mathrm{n}^{\circ}$ 27, 2011.

Punzón Moraleda, J. y Sánchez Rodríguez, F., La utilización de medios electrónicos, informáticos y telemáticos en la Ley 30/2007, de Contratos del Sector Público, La Ley, Madrid, 2009.

Sánchez Calero, F. y Sánchez-Calero Guilarte, J., Instituciones de Derecho mercantil, vol. 2, 29 edición, Cizur Menor, 2006.

UREa GonzÁLEZ., "Contribución al estudio de la factura de compraventa mercantil”, en AA.VV., Estudios de Derecho mercantil en homenaje al profesor Antonio Polo, Madrid, 1981. 

Este volumen se terminó de imprimir en la ciudad de Cuernavaca, Morelos, en diciembre de 2015, con un tiraje de mil ejemplares, más sobrantes para reposición. 
